In cooperation with the U.S. Army Corps of Engineers

\title{
Inventory of Gate-Sensing Equipment at 14 U.S. Army Corps of Engineers Dams in Texas
}

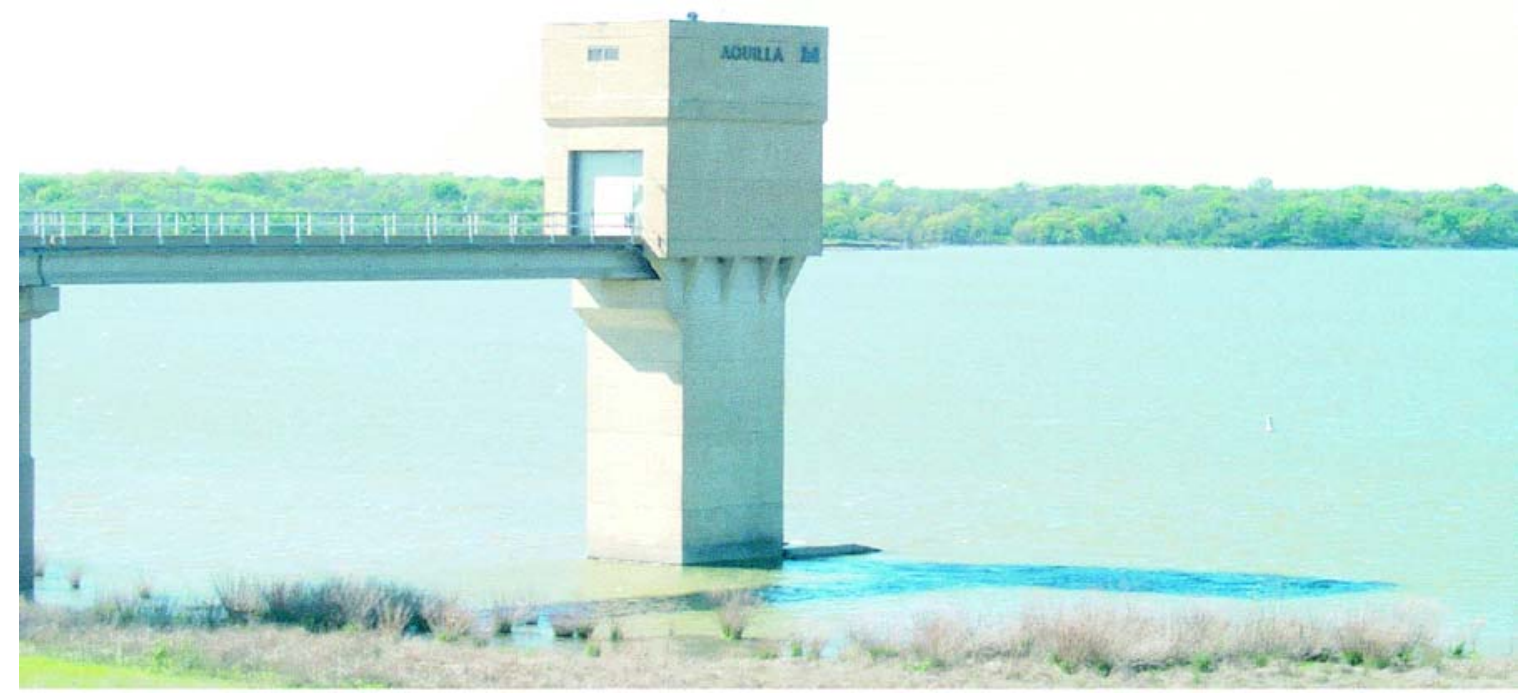

\section{Open-File Report 2005-1439}


Blank Page 


\section{Inventory of Gate-Sensing Equipment at 14 U.S. Army Corps of Engineers Dams in Texas}

By Glenn R. Harwell

In cooperation with the U.S. Army Corps of Engineers

Open-File Report 2005-1439

U.S. Department of the Interior

U.S. Geological Survey 


\section{U.S. Department of the Interior Gale A. Norton, Secretary}

\section{U.S. Geological Survey \\ P. Patrick Leahy, Acting Director}

\section{U.S. Geological Survey, Reston, Virginia: 2005}

For sale by U.S. Geological Survey, Information Services

Box 25286, Denver Federal Center

Denver, CO 80225

For more information about the USGS and its products:

Telephone: 1-888-ASK-USGS

World Wide Web: http://www.usgs.gov/

Any use of trade, product, or firm names in this publication is for descriptive purposes only and does not imply endorsement by the U.S. Government.

Although this report is in the public domain, permission must be secured from the individual copyright owners to reproduce any copyrighted materials contained within this report.

Suggested citation:

Harwell, G.R., 2005, Inventory of gate-sensing equipment at 14 U.S. Army Corps of Engineers dams in Texas: U.S. Geological Survey Open-File Report 2005-1439, 255 p. 


\section{Contents}

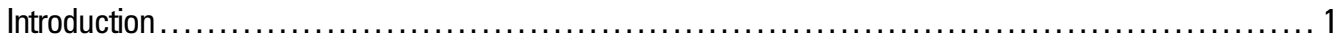

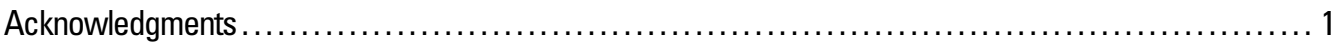

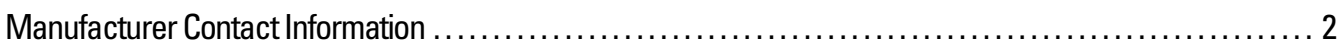

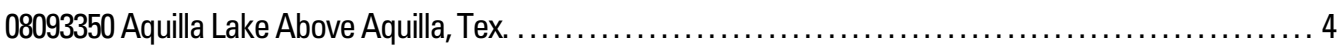

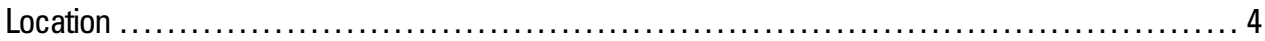

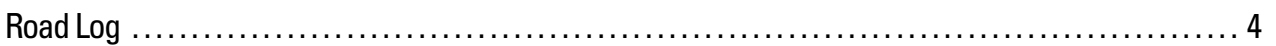

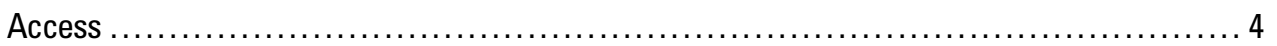

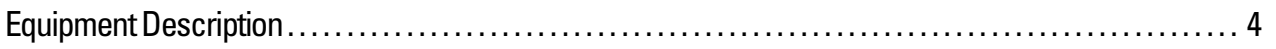

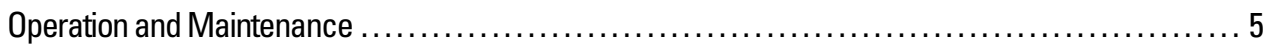

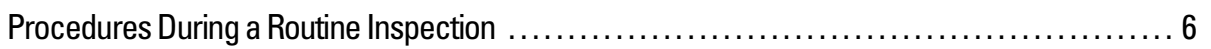

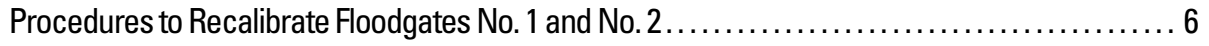

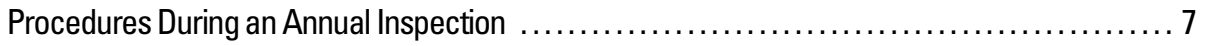

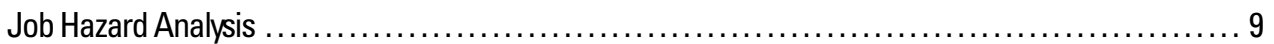

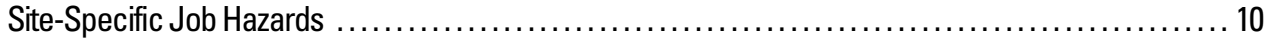

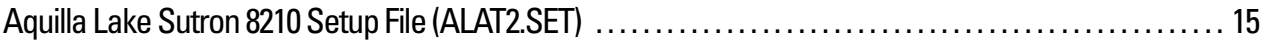

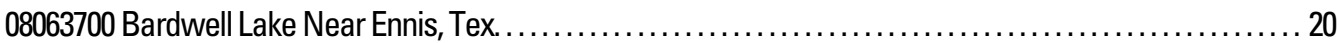

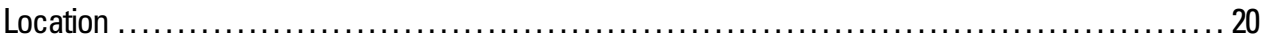

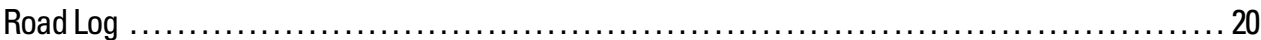

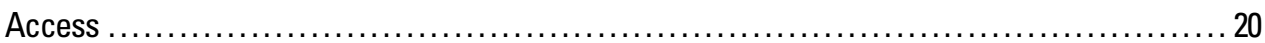

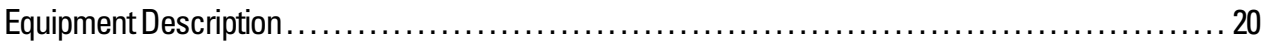

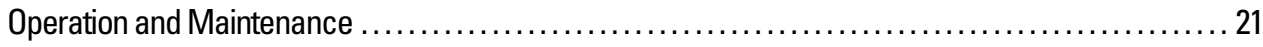

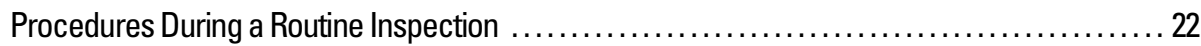

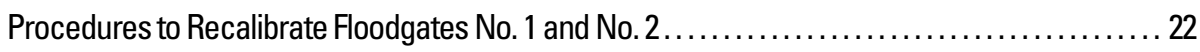

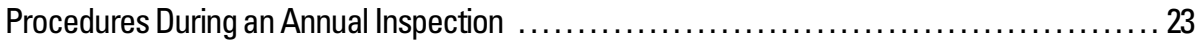

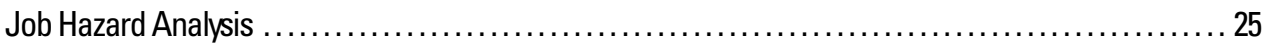

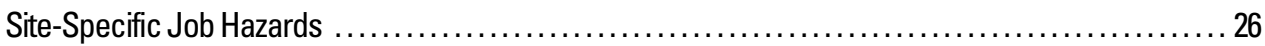

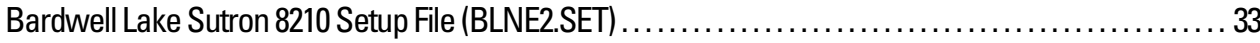

08046500 Benbrook Lake Near Benbrook, Tex. ....................................... 38

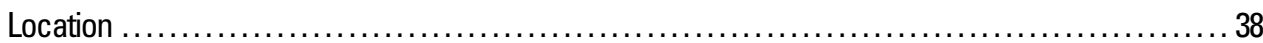

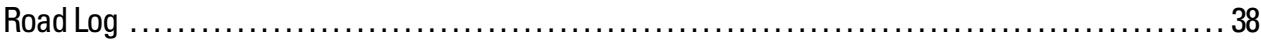

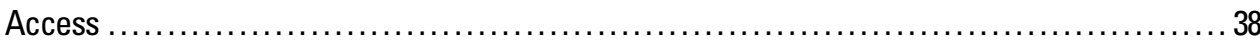

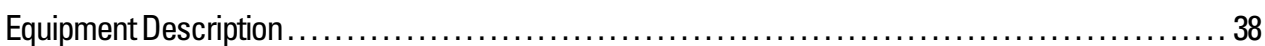

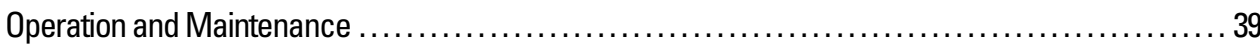

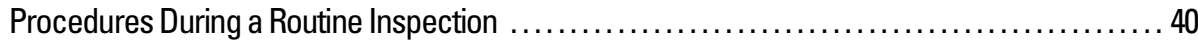

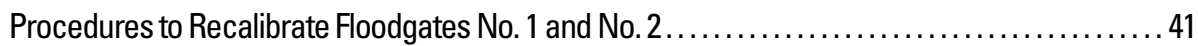

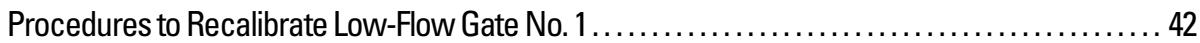

Procedures During an Annual Inspection . ................................... 42

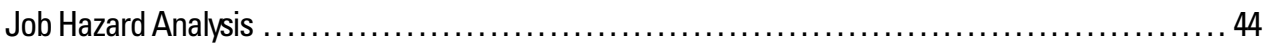

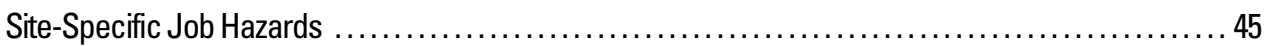

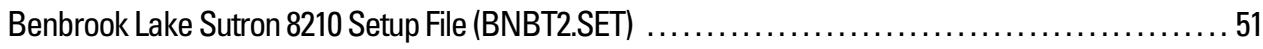

Benbrook Lake Sutron 8210 Basic Program (BNBT2.BAS) ............................. 55 


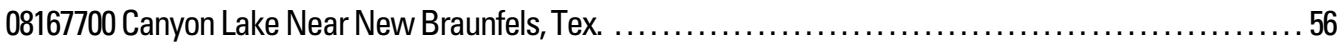

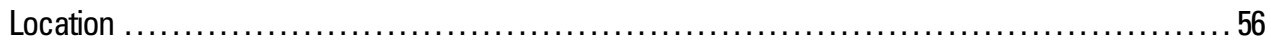

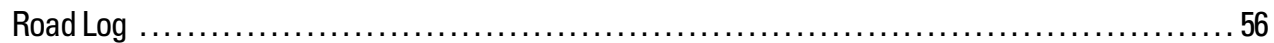

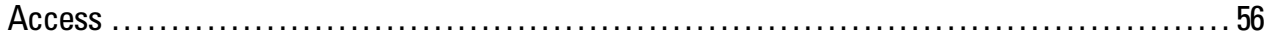

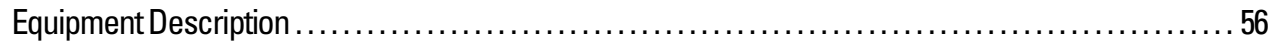

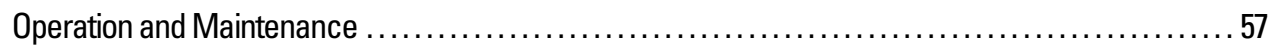

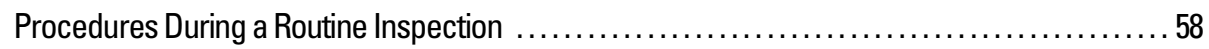

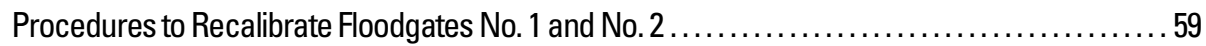

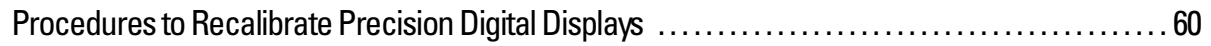

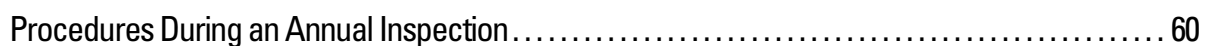

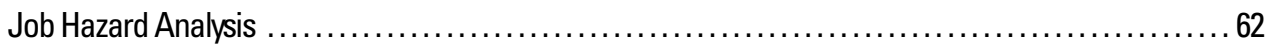

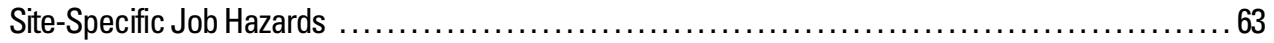

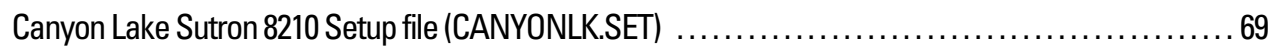

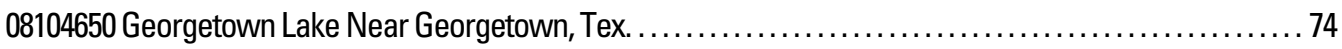

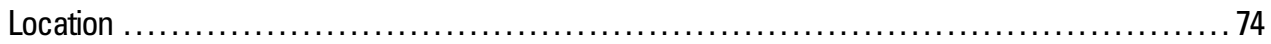

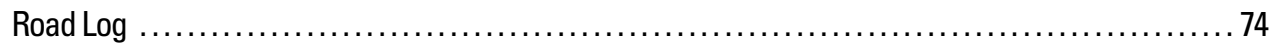

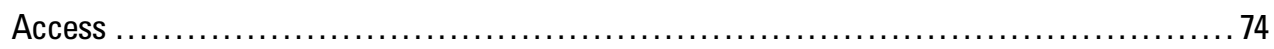

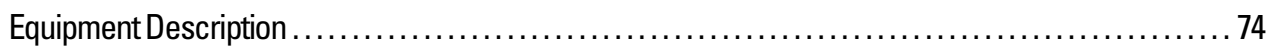

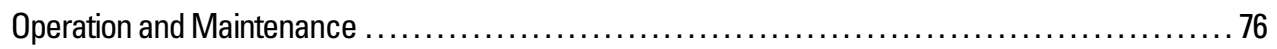

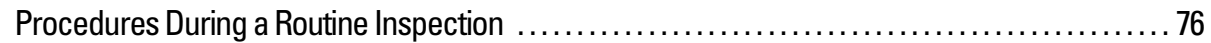

Procedures to Recalibrate Floodgates No. 1 and No. 2 and Low-Flow Gate ................. 77

Procedures to Recalibrate Red Lion Controls Digital Displays ........................ 78

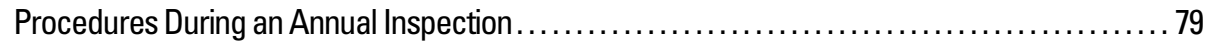

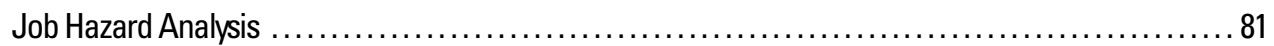

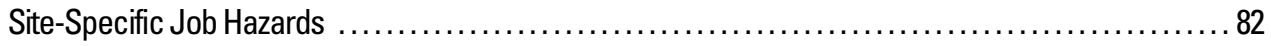

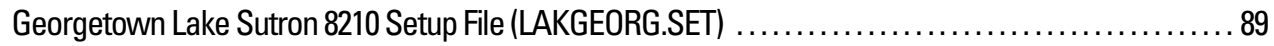

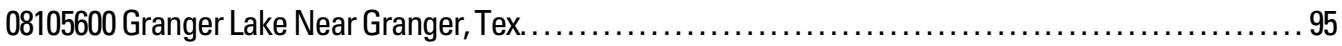

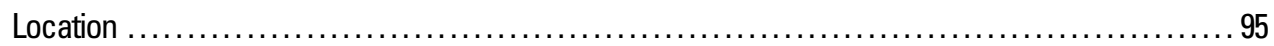

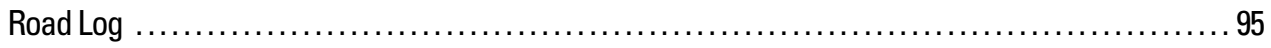

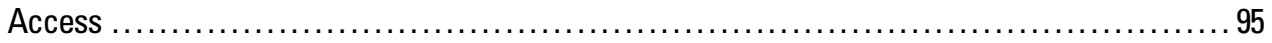

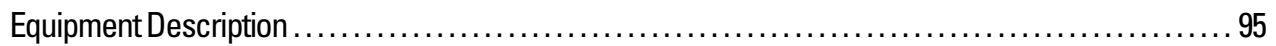

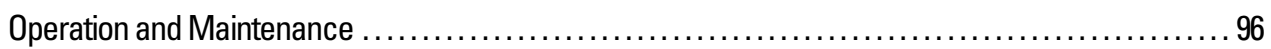

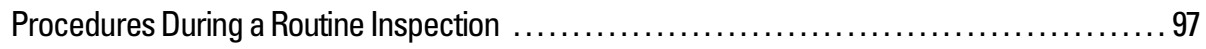

Procedures to Recalibrate Floodgates No. 1 and No. 2 and the Low-Flow Gate ............. 97

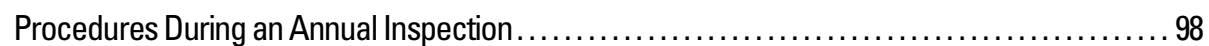

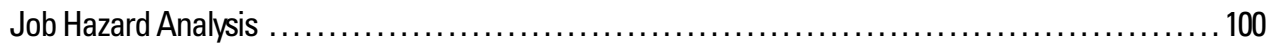

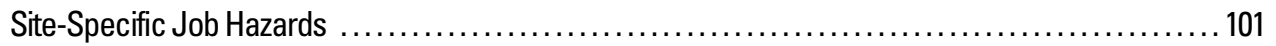

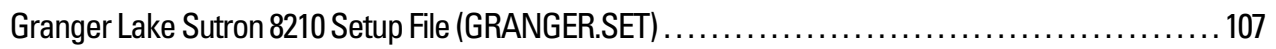

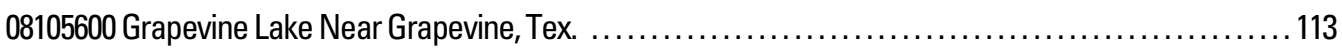

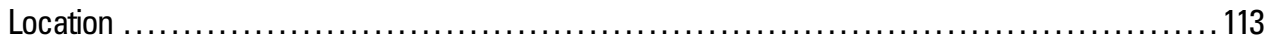

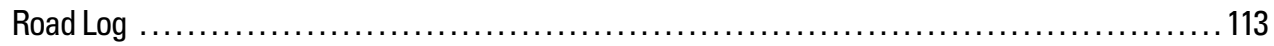

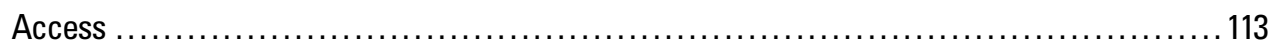

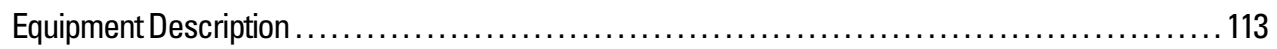

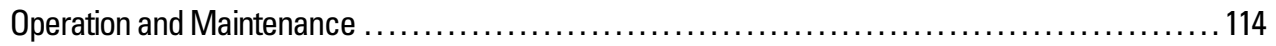

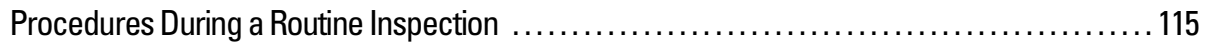




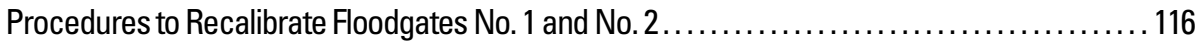

Procedures to Recalibrate Low-Flow Gates No. 1 and No. 2 ....................... 117

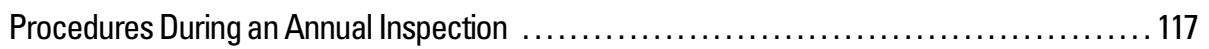

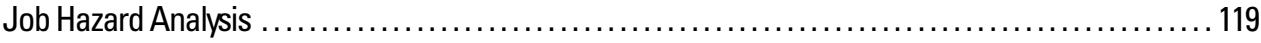

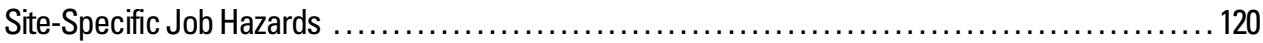

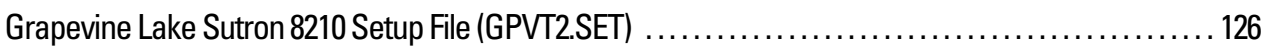

07342495 Jim Chapman Lake Near Cooper, Tex. ....................................... 132

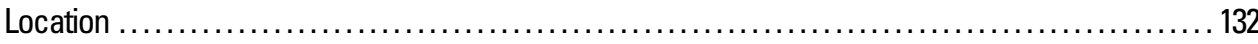

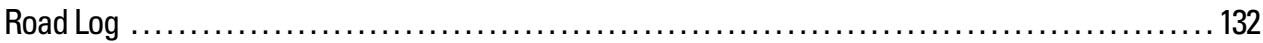

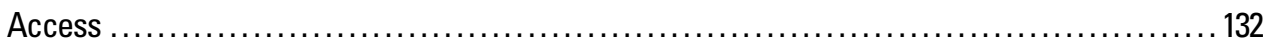

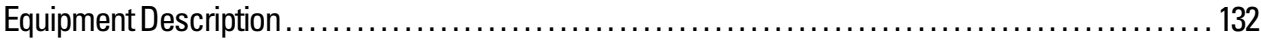

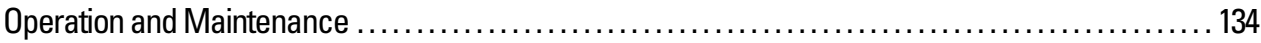

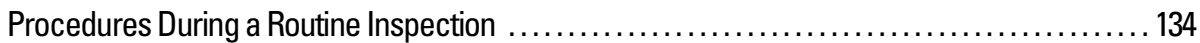

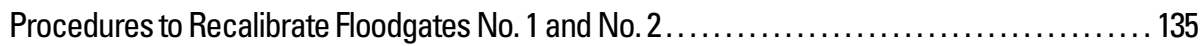

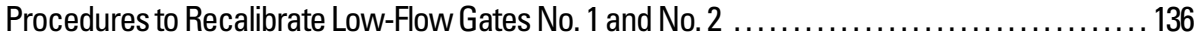

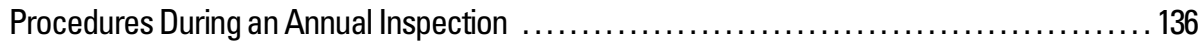

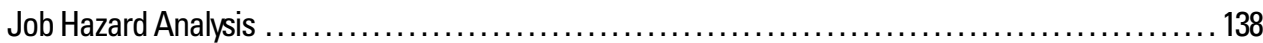

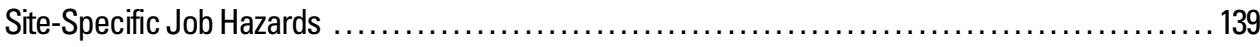

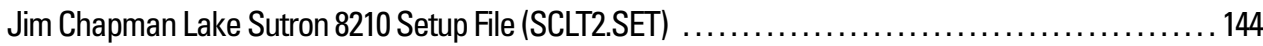

Jim Chapman Lake Sutron 8210 Basic Program (SCLT2.BAS) . .......................... 151

08049800 Joe Pool Lake Near Duncanville, Tex. .......................................... 152

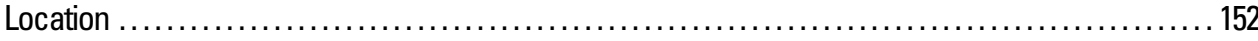

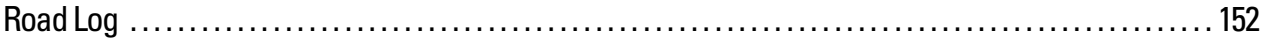

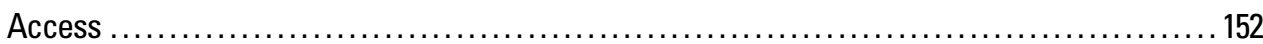

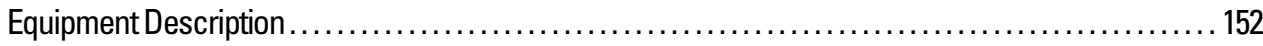

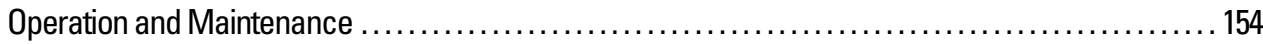

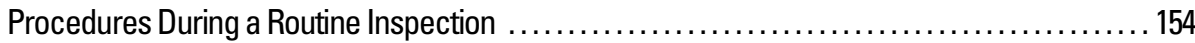

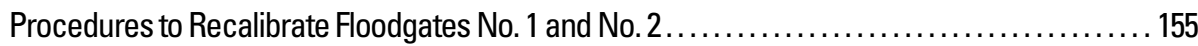

Procedures to Recalibrate the Low-Flow Gate ................................. 156

Procedures During an Annual Inspection . .................................... 156

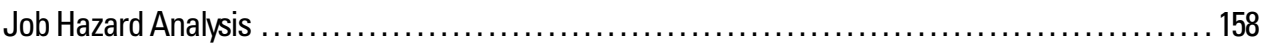

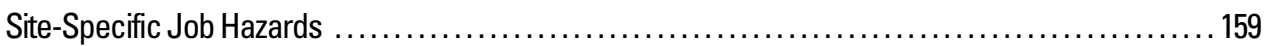

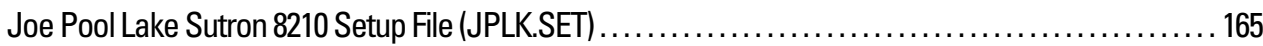

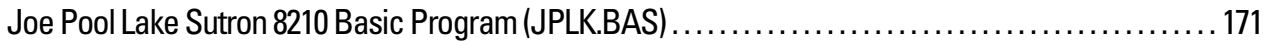

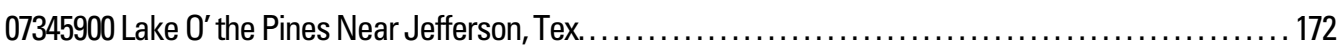

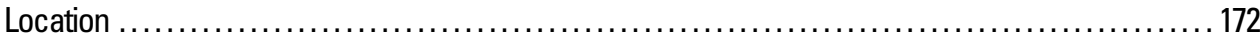

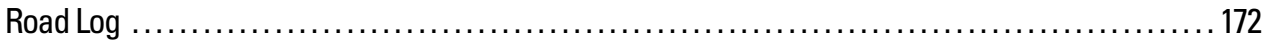

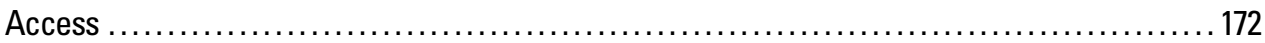

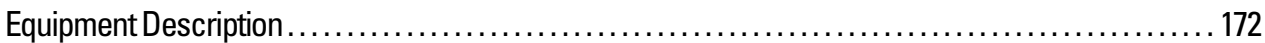

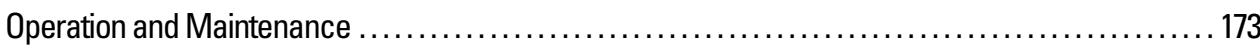

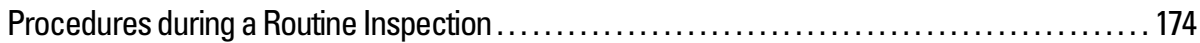

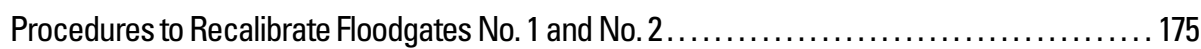

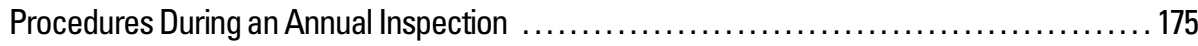

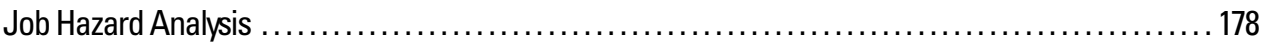

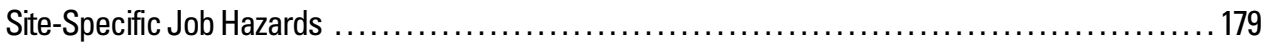




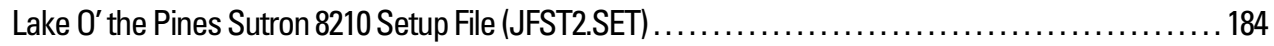

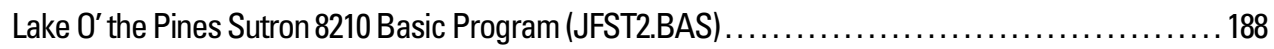

08051100 Ray Roberts Lake Near Pilot Point, Tex. ........................................ 189

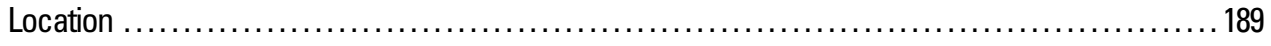

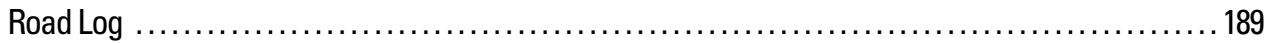

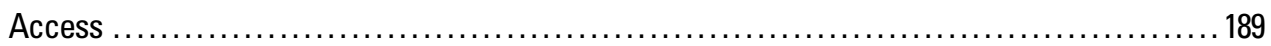

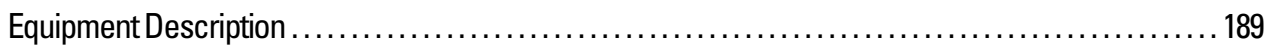

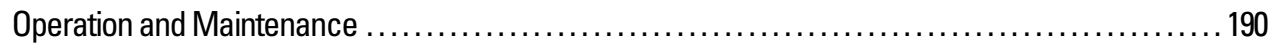

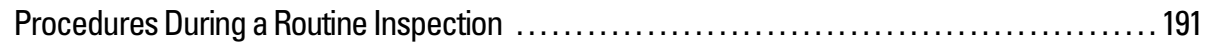

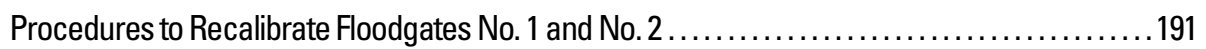

Procedures During an Annual Inspection ...................................... 192

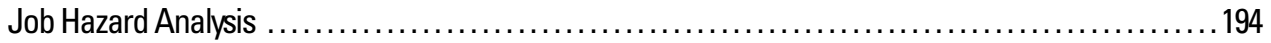

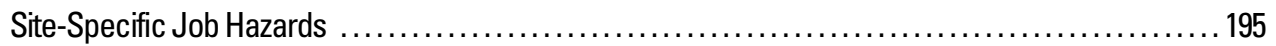

Ray Roberts Lake Sutron 8210 Setup File (RRLT2.SET) . ............................. 200

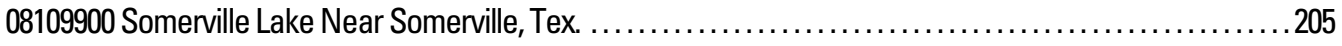

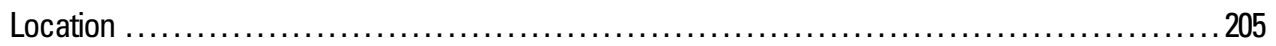

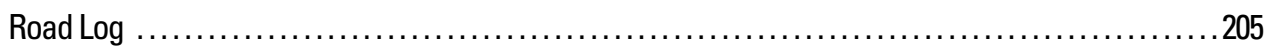

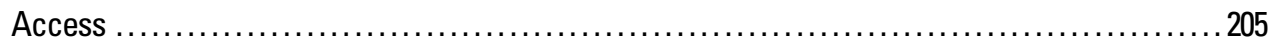

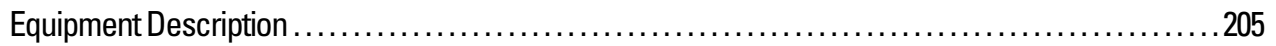

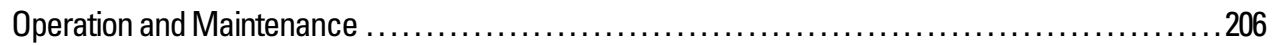

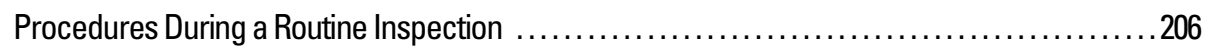

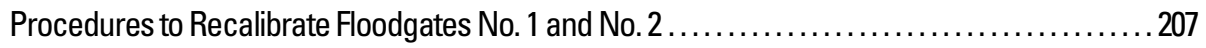

Procedures During an Annual Inspection ...................................... 207

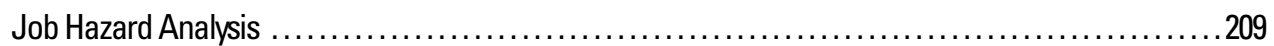

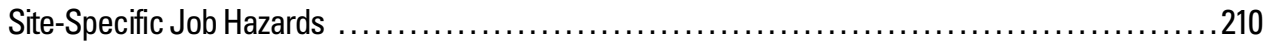

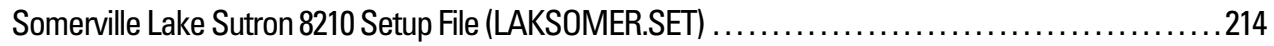

08104050 Stillhouse Hollow Lake Near Belton, Tex. ....................................... 219

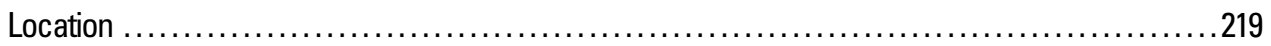

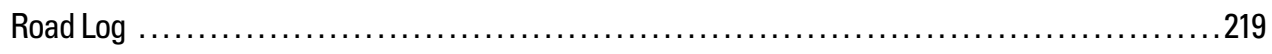

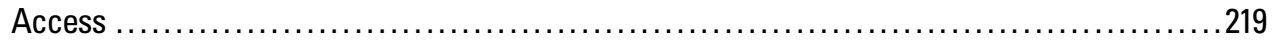

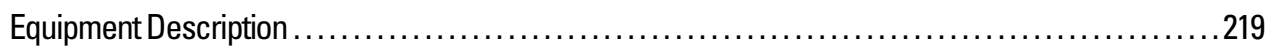

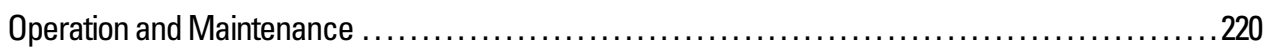

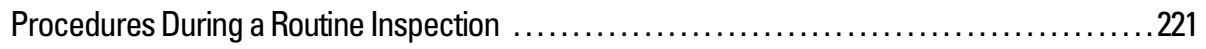

Procedures to Recalibrate Floodgates No. 1 and No. 2 and Emergency Gates No. 1 and

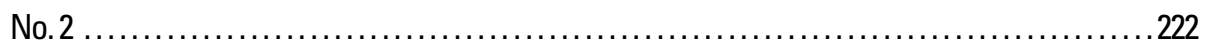

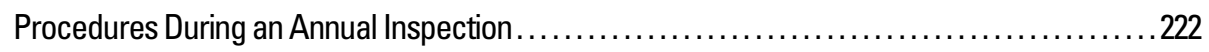

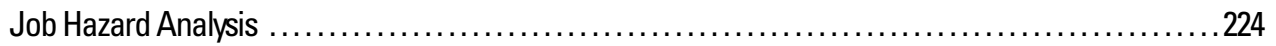

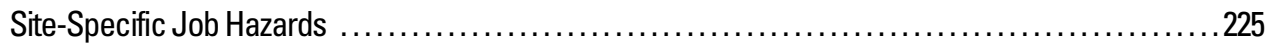

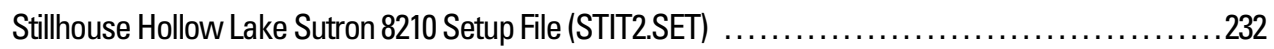

07344200 Wright Patman Lake Near Texarkana, Tex. ....................................... 238

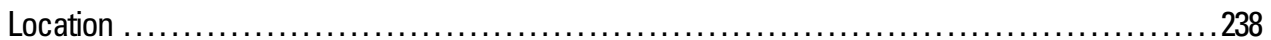

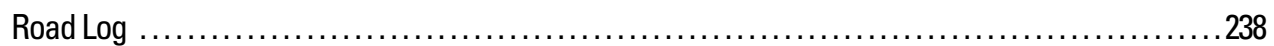

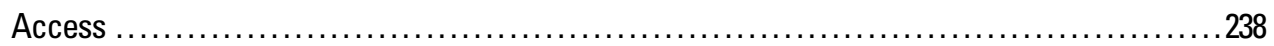

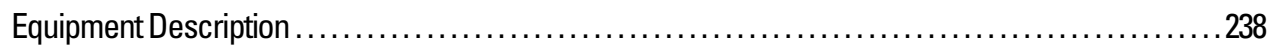

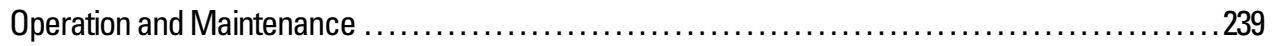




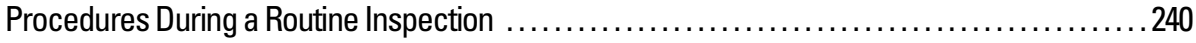

Procedures to Recalibrate Floodgates No. 1, No. 2, No. 3, and No. $4 \ldots \ldots \ldots \ldots \ldots \ldots \ldots . \ldots 241$

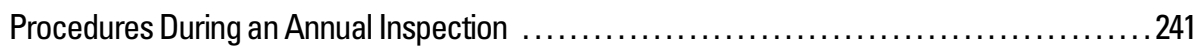

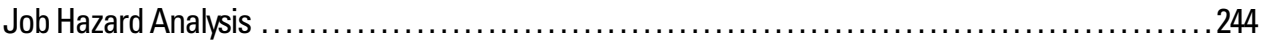

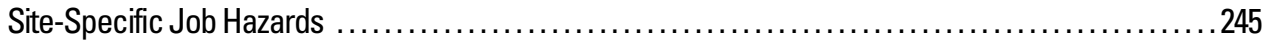

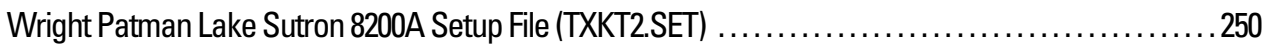

Wright Patman Lake Sutron 8200A Basic Program (TXKT2.BAS) . ......................... 255

\section{Figures}

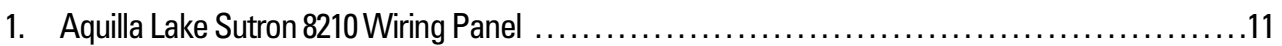

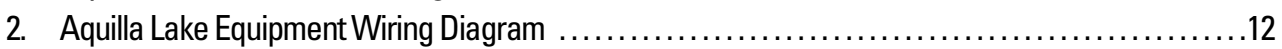

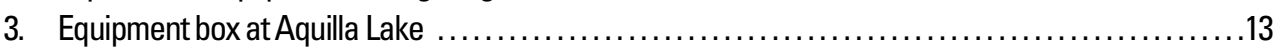

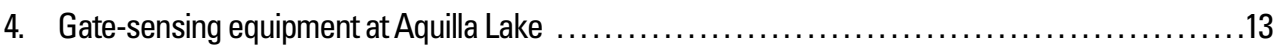

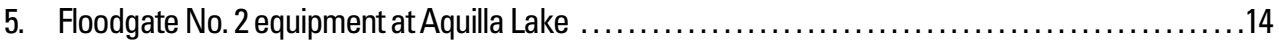

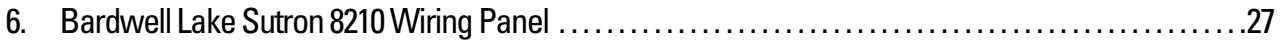

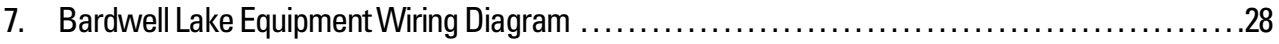

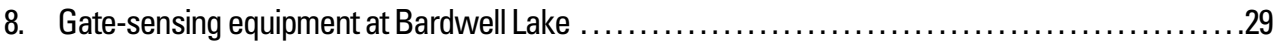

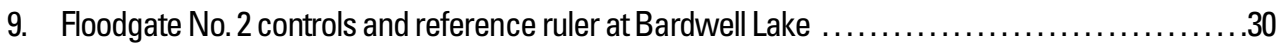

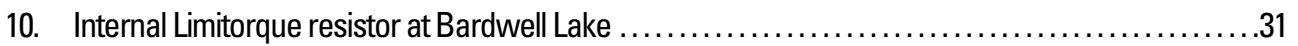

11. Gears of the Limitorque internal resistor at Bardwell Lake .................................

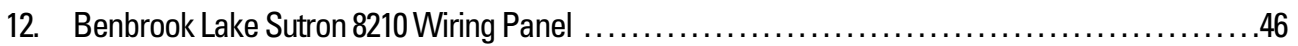

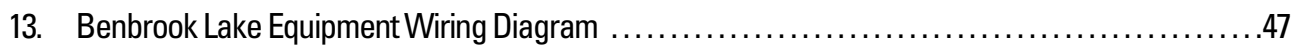

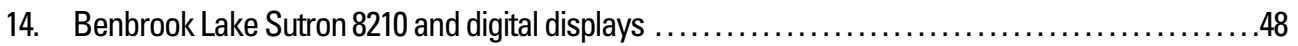

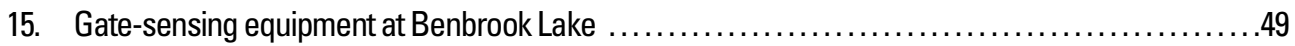

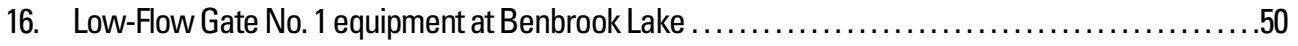

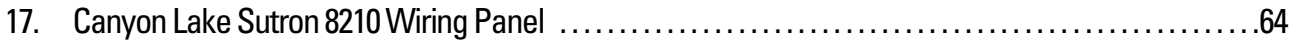

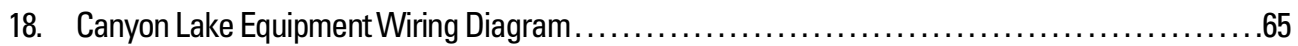

19. Precision Digital displays and control box at Canyon Lake . .............................66

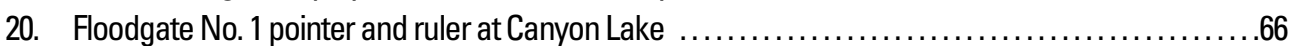

21. Floodgate No. 2 position sensor and transmitter at Canyon Lake ............................67

22. Sutron 8210 datalogger, elevator, and hydraulic pumps at Canyon Lake ....................6.68

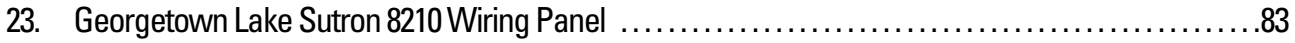

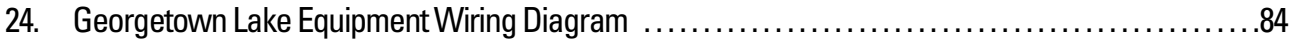

25. Equipment box with Sutron 8210 and battery at Georgetown Lake $\ldots \ldots \ldots \ldots \ldots \ldots \ldots \ldots \ldots \ldots$

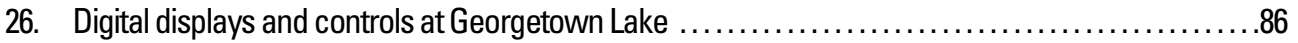

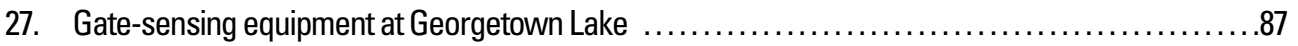

28. Equipment boxes with terminal strips connecting equipment and digital displays at

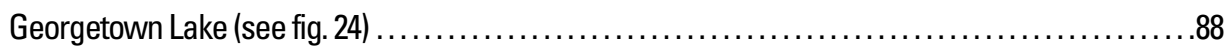

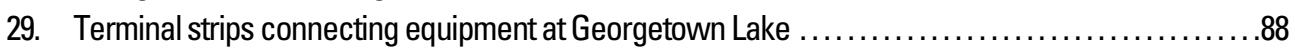

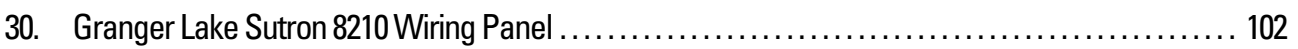

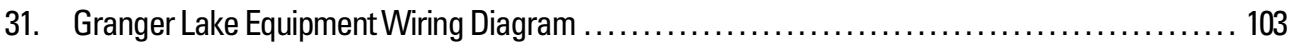

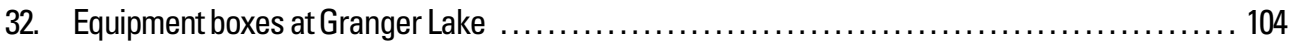

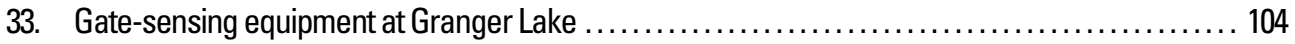

34. Low-flow gate and selective withdrawal gates at Granger Lake ......................... 105

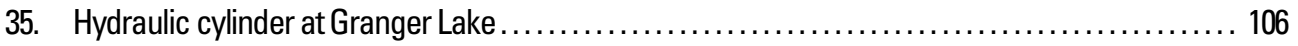

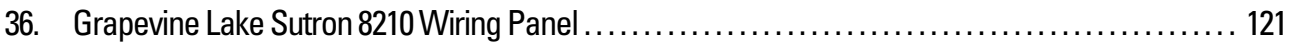




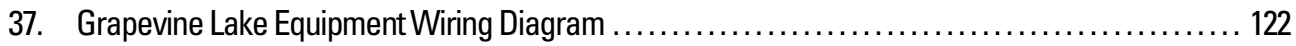

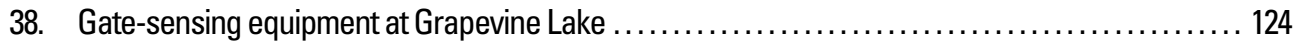

39. Sutron 8210 datalogger and wiring layout for Grapevine Lake ............................ 124

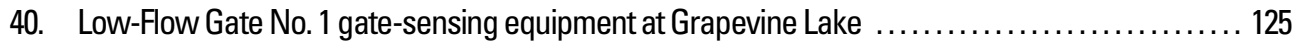

41. Jim Chapman Lake Sutron 8210 Wiring Panel ..................................... 140

42. Jim Chapman Lake Equipment Wiring Diagram .................................. 141

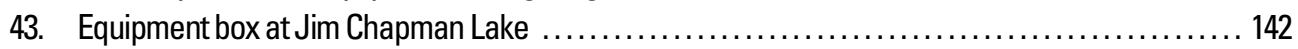

44. Low-Flow Gate No. 2 and withdrawal gates at Jim Chapman Lake ....................... 142

45. Floodgate No. 1 equipment and digital display at Jim Chapman Lake ..................... 143

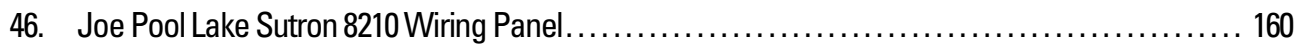

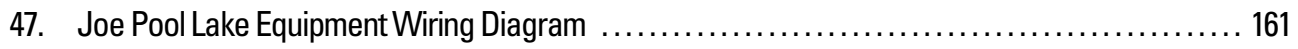

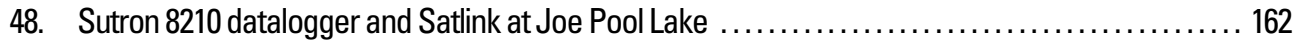

49. Digital displays and electricity supply at Joe Pool Lake ............................. 162

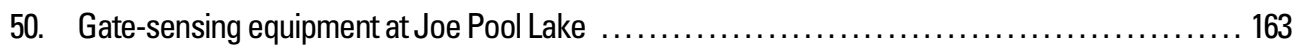

51. Low-flow gate and withdrawal gates at Joe Pool Lake ................................ 164

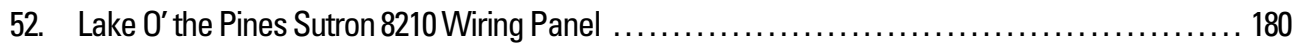

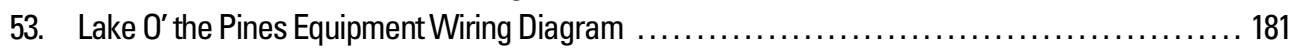

54. Sutron 8210 datalogger at Lake $O^{\prime}$ the Pines ....................................... 182

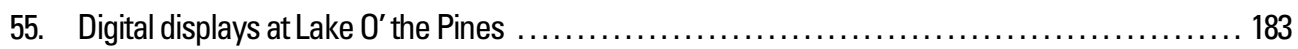

56. Gate-sensing equipment at Lake $O^{\prime}$ the Pines ...................................... 183

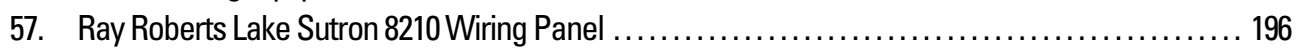

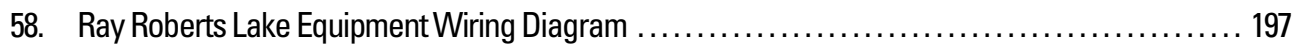

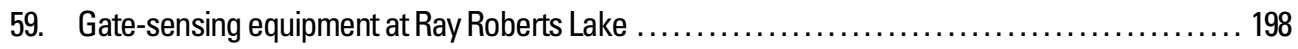

60. Ruler and pointer reference for Floodgate No. 2 at Ray Roberts Lake ...................... 199

61. Somenville Lake Sutron 8210 Wiring Panel ....................................... 211

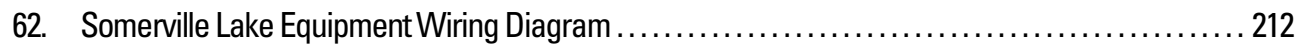

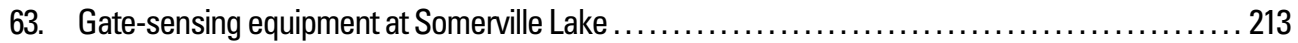

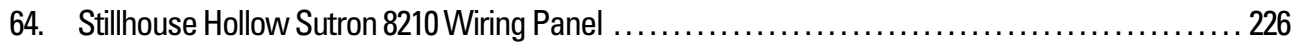

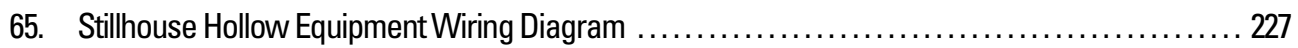

66. Sutron 8210 datalogger and gate controls at Stillhouse Hollow Lake ....................... 229

67. Manual control levers and equipment at Stillhouse Hollow Lake .......................... 230

68. Hydraulic cylinder for Floodgate No. 1 at Stillhouse Hollow Lake ........................ 231

69. Wright Patman Lake Sutron 8200A Wiring Panel .................................. 246

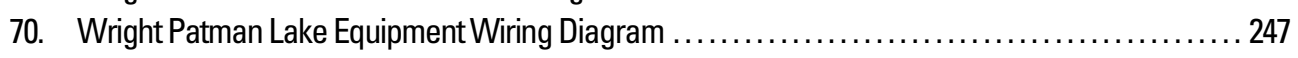

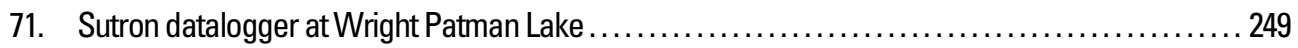

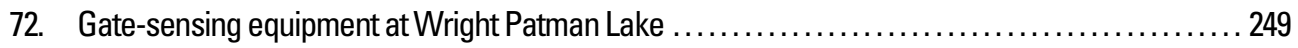

\section{Tables}

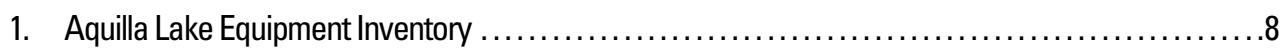

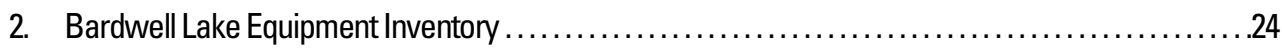

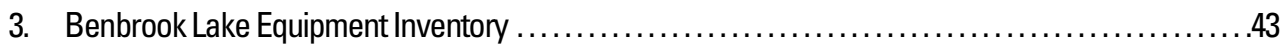

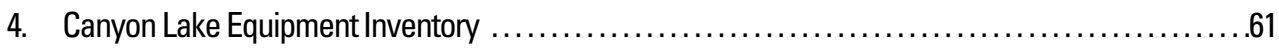

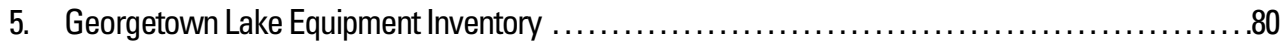

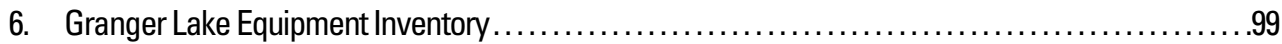

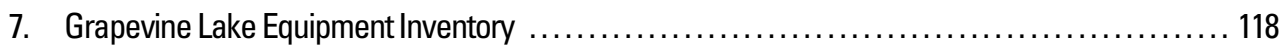

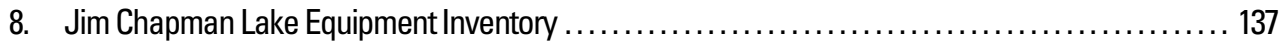

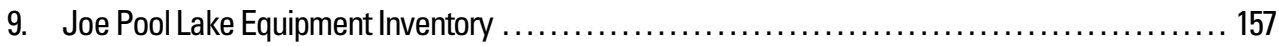




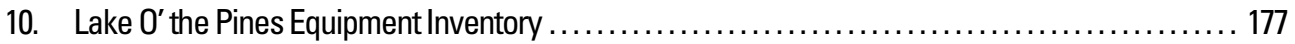

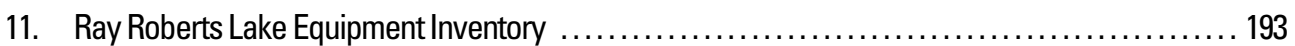

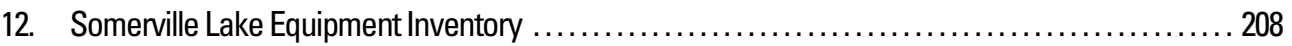

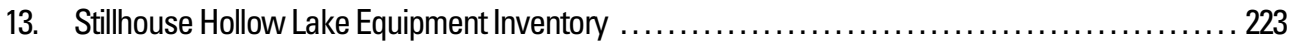

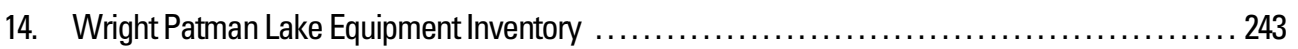

\section{Abbreviations}

A, amperes

$\mathrm{AC}$, alternating current

A-h, ampere-hours

AWG, American wire gage

CFR, Code of Federal Regulations

DC, direct current

DOT, Department of Transportation

$\mathrm{ft}$, feet

FM, Farm-to-Market Road

GPS, global positioning system

in., inches

I, Interstate Highway

lat, latitude

long, longitude

$\mathrm{mA}$, milliamperes

$\mathrm{MHz}$, megahertz

mi, miles

$\mathrm{mm}$, millimeters

OP, Branch of Operational Support

RR, Ranch Road

$\mathrm{SH}$, State Highway

SM, U.S. Geological Survey Manual

US, U.S. Highway

USACE, U.S. Army Corps of Engineers

USGS, U.S. Geological Survey

V, volts

$\mathrm{VAC}$, voltage alternating current

VDC, voltage direct current

W, watts,

WRD, Water Resources Discipline

WSC, Water Science Center 
Blank Page 


\title{
Inventory of Gate-Sensing Equipment at 14 U.S. Corps of Engineers Dams in Texas
}

\author{
By Glenn R. Harwell
}

\section{Introduction}

The U.S. Army Corps of Engineers (USACE) is a worldwide organization that provides engineering services, environmental restoration, and construction support for a wide variety of civil and military projects. The primary civil mission of the USACE is developing and managing the Nation's water resources. USACE develops projects to reduce flood damage, improve navigation channels and harbors, protect wetlands, and preserve, safeguard, and enhance the environment. Additional missions of the Corps include managing federal real estate, assisting communities with emergency operations and recovery, and providing recreation opportunities.

Accurate and timely information on reservoir gate openings is critical for managing flood pools, reducing flood damage downstream from reservoirs, delivering drinking-water supplies, and meeting an assortment of competing downstream water-use needs. Documentation, operation, and maintenance of gate sensors are needed so that reliable, timely information is available to USACE to make reservoir operation decisions.

USACE requested that the U.S. Geological Survey (USGS) prepare an inventory and documentation of existing gate-sensing equipment at 14 reservoirs that will serve as a user's manual for operating the equipment. The 14 reservoirs include Aquilla Lake, Bardwell Lake, Benbrook Lake, Canyon Lake, Georgetown Lake, Granger Lake, Grapevine Lake, Jim Chapman Lake, Joe Pool Lake, Lake O' the Pines, Ray Roberts Lake, Somerville Lake, Stillhouse Hollow Lake, and Wright Patman Lake.

This report presents the inventory and documentation of the existing gate-sensing equipment at the 14 . The report is organized by lake; information in each lake section includes location of lake and intake structure, directions to each lake (road log), access, equipment description, operation and maintenance information, job hazard analysis, wiring diagrams, photographs, and datalogger programs. The report also includes a list of contact information for the different manufacturers of equipment in service at the lakes.

\section{Acknowledgments}

The author thanks Reynold Sorgee and Paul Lauderdale, USACE, for their assistance, particularly during the reconnaissance phase. Thanks also are extended to all other USACE staff members at the reservoirs who were very helpful and willing to answer questions and assist in any way. 


\section{Manufacturer Contact Information}

\section{Celesco Inc.}

Address: 20630 Plummer St. Chatsworth, CA 91311

Web address: $\quad$ Www.celesco.com
Telephone:(800) 423-5483 (Main)

Fax: (818) 701-2799

Note:For service and technical information call (916) 455-7379 and ask for Scott Crum.

\section{Limitorque}

Address: P.O. Box 11318

Lynchburg, VA 24506

Telephone:(434) 528-4400

Web address: $\quad$ www.limitorque.com

Note: $\quad$ For service and technical information call (434) 845-9732 and ask for Frank Hannell.

\section{Precision Digital}

Address: 19 Strathmore Rd.

Telephone:(800) 610-5239

Natick, MA 01760

Fax:

(508) 655-8990

Web address: $\quad$ www.predig.com

\section{Red Lion Controls}

Address: 20 Willow Springs Cir. York, PA 17402

Web address: $\quad$ www.redlion.net

\section{Schmitz Engineering Liaison}

Address: 124 S. Dodge St.

PO BOX 542

Burlington, WI 53105

Web address: $\quad$ www.encoderoptical.com
Telephone:(717) 767-6511

Fax: (717) 764-0839

\section{Shand \& Jurs, an L\&J Technologies Company}

Address: 5911 Butterfield Rd.

Hillside, IL 60162

Web address: www.ljtechnologies.com

Telephone:(262) 763-3036 (Main)

Fax: (262) 763-8063

Note: $\quad$ For service and technical information ask for George Hroma at extension 168. 


\section{Sutron Corporation}

Address: 21300 Ridgetop Cir. Sterling, VA 20166

Web address: $\quad$ www.sutron.com

Whessoe Varec, Inc.

Address: 5834 Peachtree Corners East Norcross, GA 30092
Telephone:(703) 406-2800 (Main)

Fax: (703) 406-2801
Telephone:(770) 447-9202 (Main)

Fax: (770) 662-8939

Web address: $\quad$ www.whessoevarec.com

Note: $\quad$ For service and technical help ask for Kevin Charles or Danny Owens. 


\section{Aquilla Lake Above Aquilla, Tex.}

\section{Location}

Lat $31^{\circ} 53 ' 59^{\prime \prime}$, long 97²'09", Hill County, $450 \mathrm{ft}$ upstream from the FM 310 crossing of Aquilla Dam on Aquilla Creek, and 3.4 mi north-northeast of Aquilla.

\section{Road Log}

From USGS Texas WSC-Fort Worth, take I-35 west toward Hillsboro. Exit on FM 310 and travel west 8 mi to Aquilla Lake and Dam. FM 310 crosses the dam and continues past the intake structure.

\section{Access}

Before visiting the site, call the Aquilla Dam USACE office at 254-622-3332 to let them know you will be servicing the site. The key required to access the equipment is available from staff at the WSC-Fort Worth. The same key is used to open the padlock to the gate off FM 310 to the intake structure and the padlock to the door of the intake structure. The door to the intake structure does not have an alarm that needs to be disabled before entering.

\section{Equipment Description}

Refer to table 1, "Aquilla Lake equipment inventory," for a complete list of equipment and to figures 1-5 for equipment wiring diagrams and photographs of equipment. Two main floodgates and two emergency gates are raised and lowered by EIM Controls electric valve operators. The floodgates are labeled D-1 and D-2 (D indicates downstream). The emergency gates are labeled U-1 and U-2 (U indicates upstream). D-1 and D-2 will be referred to as Floodgates No. 1 and No. 2 in this description to be consistent with naming conventions used at other dams. Floodgate No. 1 is on the right side of the intake structure (facing upstream) and Floodgate No. 2 is on the left. Similarly, Emergency Gates No. 1 and No. 2 are on the right and left sides (facing upstream), respectively, of the intake structure.

All of the gates (flood and emergency) use Shand \& Jurs 92020 automatic tank level gages to indicate the position of the gates. For the floodgates, position is relayed to a Sutron 8210 datalogger with Whessoe Varec 8200 series liquid level transmitters. The emergency gates do not have transmitters; therefore, the position of the gates is not recorded by the datalogger.

A steel tape runs from the top of each gate to the 92020 tank level gage, where it wraps around a storage drum connected to a Neg'ator constant-force spring motor. The Neg'ator spring motor consists of a prestressed stainless steel tape that is formed into a coil and stored on a small storage drum. The free end of the coil is wrapped backwards onto a larger output drum, then fastened to the drum. When the steel tape connected to the top of the gate winds up in the 92020 gage as the gate is raised, the tape of the Neg'ator spring motor will wind up onto the small storage drum. Conversely, when the steel tape connected to the top of the gate unwinds as the gate is lowered, the tape of the Neg'ator spring motor will unwind from the small storage drum and wind up on the 
output drum. In both instances the Neg' ator spring motor functions to provide a constant amount of force (torque) on the steel tape attached to the gate regardless of the amount of deflection. The movement of the small storage drum rotates a shaft inside the 8200 position transmitter. The shaft is coupled to a worm gear, which in turn drives the shaft of a potentiometer. Rotation of the shaft causes a change in the output current of the transmitter. The variations in current output are carried to the Sutron 8210 datalogger by two wires. At the datalogger, the current is passed through a resistor so the voltage can be measured. The output current of the transmitters varies from 4 to $20 \mathrm{~mA}$.

Gate-sensing equipment that serves as a reference for the two floodgates is not available at Aquilla Dam. The Shand \& Jurs and Whessoe Varec units are assumed to measure the true position of the gates.

A low-flow gate is located between the two floodgates. However, the low-flow gate is not monitored with gate-sensing equipment. A hand crank is used to raise and lower the gate. As the gate is raised and lowered, a pointer moves up and down along a ruler to indicate the position of the gate.

The Sutron 8210 datalogger is powered by a 12-VDC battery, which is charged by an automatic sealed lead-acid battery charger connected to a $120-\mathrm{VAC}$ wall outlet. The position transmitters are powered by 24 VDC from a transformer inside the equipment box with the Sutron 8210 . Varec offers an onboard power source that would eliminate the transformer and $\mathrm{AC}$ power inside the equipment box. Instead, AC power would run directly to the position transmitter and be converted to 24 VDC by an internal transformer.

The setup file (ALAT2.SET) for the datalogger is stored on the RAM card that is kept inside the Sutron equipment box. A hard copy of the setup file is also kept in the station folder.

The positions of Floodgates No. 1 and No. 2 are transmitted by satellite and posted on the USACE Web site (http://www.swf-wc.usace.army.mil) under Daily Reports/Gate Sensor Report. The USACE reports hourly data; however, the Sutron datalogger measures and records the gate position for the two gates every 15 minutes.

Floodgates No. 1 and No. 2 are SEVGATE1 and SERGATE2, respectively, in the Sutron setup file.

\section{Operation and Maintenance}

Operation and maintenance information for the equipment at Aquilla Dam includes descriptions of different procedures required to maintain equipment such as routine inspections, recalibration of Floodgates No. 1 and No. 2, and annual inspections. The purpose of a site visit and the actions taken should be documented in the logbook kept near the datalogger. Include the date, time, actions, and personnel conducting the site visit in the logbook. This section lists some of the potential problems that might occur with the equipment in service and possible solutions to the problems. Refer to the Operations Manuals for the individual pieces of equipment when further detail is required. The information included here is basic operations and maintenance information.

For each visit to the site, personnel should carry all of the necessary tools required to service the equipment. The tools required to perform all of the tasks listed include the following:

- Screwdrivers, flat and Phillips head

- Crescent wrench, 10-in. 
- Stepladder, $10-\mathrm{ft}$

- Electrical tape

- Digital multimeter

- Pliers

- Ruler

- Laptop computer capable of connecting (with RS-232 port and 9-pin cable) to Sutron 8210

- Sutron 8210 Operations Manual

- Shand \& Jurs 92020 and 92021 Instruction Manuals

- Whessoe Varec 8200 Installation and Operations Manual

- Battery load tester

- Spare battery

- Flashlight

- Silicone sealant

\section{Procedures during a routine inspection}

- Check the enclosure to the Sutron 8210 datalogger for damage and moisture. If moisture is entering the enclosure, seal any openings with silicone.

- Scroll through the VIEW DATA/LIVE READINGS menu and check that the datalogger is making measurements.

- Check the antenna and make sure connections are secure and waterproofed. Replace electrical tape around connections if old and brittle.

- Check the battery voltage under the LIVE READINGS menu on the Sutron 8210.

- If voltage is low (less than $11.5 \mathrm{~V}$ ), test the battery with a load tester and make sure the voltage remains above the recommended voltage specific to the load tester being used. Replace battery as needed.

- Remove drain plug on bottom of position sensor and allow water to drain out.

- Verify that the Shand \& Jurs position sensors and the Sutron 8210 datalogger measure the same values for the positions of Floodgates No. 1 and No. 2. If they measure the same (within $0.01 \mathrm{ft}$ ), no action is required. If the values differ, refer to the recalibration procedures.

- Before leaving the site, make sure the Sutron 8210 is reading ON \& TX under RECORDING.

\section{Procedures to recalibrate Floodgates No. 1 and No. 2}

- Completely lower the gate requiring calibration and set the Shand \& Jurs position sensor to measure 0.00 . To do this, open the counter access cover on top of the unit above the dial window. Hold the notched wheel, located to the right of the increments wheel, and turn the increments wheel until the counter measures the correct position, 0.00 . If the position sensor measures 0.00 when the gate is lowered completely, only the Sutron requires calibration.

- Caution: Before executing this procedure, make sure the emergency gates are closed. To calibrate the Sutron after setting the Shand \& Jurs unit to measure 0.00 , first record the current slope and offset for the gate being calibrated. Next, set the slope and the offset to 1.00 and 0.00 , respectively. With the gate still completely closed, scroll down to SYSTEM SETUP. Press the right arrow once 
and scroll down to CONFIG SENSORS. Press the right arrow once and scroll down to the gate that is being calibrated. With the correct gate selected, press the right arrow once and scroll down to VALUE. Enter the correct value, which would be 0.00 , then press the SET button. Next, open the gate as much as possible so that the instrument will be calibrated over the entire range of gate positions. With the gate open as much as possible, enter the value from the Shand \& Jurs dial into the VALUE field and press the SET button. The datalogger will calculate the slope and the offset from the two known positions entered.

- Verify that the Shand \& Jurs position sensor and the Sutron 8210 datalogger are now measuring the same position with the gate open as much as possible. After verification, close the gate completely and check that both measure 0.00 with the gate completely closed. If so, the calibration is complete; if not, perform the calibration again.

- Whenever a change is made to the setup file in the datalogger, download the new file to the RAM card kept at the site. To do this, insert the RAM card into the socket and turn on the 8210. Scroll down to the DUMP DATA menu. Press the right arrow once, then press the down arrow until WRITE CARD SETUP is displayed. Press the SET button and wait for the file to be transferred from the datalogger to the RAM card. To transfer the file from the RAM card to the datalogger, scroll down to the DUMP DATA menu. Press the right arrow once, then press the down arrow until READ CARD SETUP is displayed. Press the right arrow to access the setup file. Transfer the selected file to the datalogger by pressing the SET button.

- Record changes to the slope or the offset in the logbook.

\section{Procedures during an annual inspection}

- During an inspection the emergency gates are lowered, and the floodgates are raised all the way up and cleaned and inspected. As the gates are lowered after being serviced, check that the position sensors and datalogger measure the same values. If not, follow the instructions to recalibrate the instruments.

- After the inspection, follow all of the procedures for a routine inspection. 
Table 1. Aquilla Lake equipment inventory.

[See table of contents for abbreviated units; --, not available or not applicable]

\begin{tabular}{|c|c|c|c|c|}
\hline $\begin{array}{c}\text { Item } \\
\text { no. }\end{array}$ & Item description & Manufacturer & Model no. & \\
\hline 1. & Floodgate No. 1 position sensor & Shand \& Jurs & 92020 & $\begin{array}{l}\text { Gate is SEVGATE1 in Sutron setup and equipment is } \\
\text { labeled D-1 (D indicates downstream) }\end{array}$ \\
\hline 2. & $\begin{array}{l}\text { Floodgate No. } 1 \text { position } \\
\text { transmitter }\end{array}$ & Whessoe Varec & 82000100 & $\begin{array}{l}\text { Analog transmitter with current output of } 4 \text { to } 20 \mathrm{~mA} \\
\text { and input of } 15 \text { to } 48 \text { VDC }\end{array}$ \\
\hline 3. & $\begin{array}{l}\text { Wire for position transmitter } \\
\text { No. } 1\end{array}$ & -- & -- & $36 \mathrm{ft}$ of $18 \mathrm{AWG} / 6$ wires but only 2 wires are used \\
\hline 4. & Floodgate No. 2 position sensor & Shand \& Jurs & 92020 & $\begin{array}{l}\text { Gate is SERGATE2 in Sutron setup and equipment is } \\
\text { labeled D-2 (D indicates downstream) }\end{array}$ \\
\hline 5. & $\begin{array}{l}\text { Floodgate No. } 2 \text { position } \\
\text { transmitter }\end{array}$ & Whessoe Varec & 82000100 & $\begin{array}{l}\text { Analog transmitter with current output of } 4 \text { to } 20 \mathrm{~mA} \\
\text { and input of } 15 \text { to } 48 \text { VDC }\end{array}$ \\
\hline 6. & $\begin{array}{l}\text { Wire for position transmitter } \\
\text { No. } 2\end{array}$ & -- & -- & $52 \mathrm{ft}$ of $18 \mathrm{AWG} / 6$ wires but only 2 wires are used \\
\hline 7. & Stage shaft encoder & Sutron & $5600-0530$ & -- \\
\hline 8. & Rain gage & $\begin{array}{l}\text { Texas Electronics, } \\
\text { Inc. }\end{array}$ & TR-525I & -- \\
\hline 9. & Datalogger & Sutron & 8210 & -- \\
\hline 10. & Battery & Power Sonic & PS-12550U & $12-\mathrm{V}, 55.0-\mathrm{A}-\mathrm{h}$ battery for Sutron 8210 \\
\hline 11. & Battery charger & -- & -- & No label or marker on charger \\
\hline 12. & Transformer & Power-One & HB2-1.2-A & $\begin{array}{l}\text { Converts } 120 \text { VAC to } 24 \text { VDC for power to position } \\
\text { transmitters }\end{array}$ \\
\hline 13. & Antenna & Synergetics & 18B & $\begin{array}{l}\text { 10-ft antenna mounted on downstream side of intake } \\
\text { structure on top of pipe }\end{array}$ \\
\hline 14. & Antenna cable & Saxton & $8282 \mathrm{RG} 8 / \mathrm{U}$ & 36-ft cable from Sutron 8210 to antenna \\
\hline 15. & Antenna polyphaser & PolyPhaser & IS-B6OLN-C2-ME & -- \\
\hline
\end{tabular}




\section{Job Hazard Analysis}

Required protective clothing, safety equipment, and supplies: Personal flotation device (PFD), reflective vest, gloves, steel-toed shoes, waders, cell phone, first aid kit, fire extinguisher, rotating or strobe type emergency lights, drinking water.

\begin{tabular}{|c|c|c|}
\hline $\begin{array}{l}\text { Sequence of basic } \\
\text { job steps }\end{array}$ & $\begin{array}{l}\text { Potential } \\
\text { accident or hazard }\end{array}$ & Recommended safe job procedures \\
\hline $\begin{array}{l}\text { Upon job } \\
\text { assignment }\end{array}$ & $\begin{array}{l}\text { Water-related accident or } \\
\text { injury }\end{array}$ & $\begin{array}{l}\text { Employees working in and around water must receive } \\
\text { training specified in WRD Memo 2000.10, "Policy for } \\
\text { safety training associated with over-water activities." }\end{array}$ \\
\hline $\begin{array}{l}\text { Loading and } \\
\text { unloading } \\
\text { equipment }\end{array}$ & $\begin{array}{l}\text { Pinched fingers, mashed } \\
\text { toes, or strained back }\end{array}$ & $\begin{array}{l}\text { Be aware of hand placement. Wear protective gloves and } \\
\text { steel-toed shoes. Use proper lifting techniques. Lift with } \\
\text { legs. Use extra caution lifting heavy sounding weights. }\end{array}$ \\
\hline $\begin{array}{l}\text { Driving to and } \\
\text { returning from work } \\
\text { site }\end{array}$ & $\begin{array}{l}\text { Traffic accidents, vehicle } \\
\text { flooding, or drowning }\end{array}$ & $\begin{array}{l}\text { Drivers of USGS vehicles must have Drivers Safety } \\
\text { Training (SM 445-2-H, chap. 16). Be alert to traffic in } \\
\text { area, obey all traffic laws, and reduce speed when weather } \\
\text { conditions are bad. Do not drive across flooded highways } \\
\text { unless water depth and bridge conditions are known to be } \\
\text { safe. }\end{array}$ \\
\hline Parking vehicle & $\begin{array}{l}\text { Personal and vehicle } \\
\text { safety when exiting } \\
\text { vehicle in traffic; bank } \\
\text { collapse or bridge failure }\end{array}$ & $\begin{array}{l}\text { Use rotating or strobe emergency lights, follow site } \\
\text { traffic-control plan, wear DOT Type III reflective vest } \\
\text { when working in or near roadway. Park away from stream } \\
\text { at a safe distance from banks. }\end{array}$ \\
\hline $\begin{array}{l}\text { Set up traffic- } \\
\text { control equipment }\end{array}$ & $\begin{array}{l}\text { Personal and public } \\
\text { safety }\end{array}$ & $\begin{array}{l}\text { Employees working in or near roadways must have Work } \\
\text { Zone Traffic-Control Safety Training. Remain alert to } \\
\text { traffic conditions. }\end{array}$ \\
\hline $\begin{array}{l}\text { Working at field } \\
\text { site }\end{array}$ & Drowning & $\begin{array}{l}\text { Employees are required to wear a PFD when working in, } \\
\text { on, or over any body of water. There are no exemptions } \\
\text { for employees in the Texas WSC. PFDs will be } \\
\text { international orange in color and equipped with reflective } \\
\text { tape in accordance with } 46 \text { CFR } 25.25-15 \text {. Self-inflating } \\
\text { PFDs are not to be worn by employees who have not had } \\
\text { In-Water Safety Training. }\end{array}$ \\
\hline $\begin{array}{l}\text { Working at field } \\
\text { site }\end{array}$ & Trips, slips, and falls & $\begin{array}{l}\text { Follow path clear of obstructions and with minimal slope; } \\
\text { avoid slippery surfaces. Walk cautiously on steep slopes } \\
\text { or paths with loose material. Use appropriate footwear for } \\
\text { the terrain and conditions. Follow the safest, not the } \\
\text { fastest path! }\end{array}$ \\
\hline $\begin{array}{l}\text { Working at field } \\
\text { site }\end{array}$ & $\begin{array}{l}\text { Dehydration, heat } \\
\text { exhaustion, heat stroke, } \\
\text { or sunburn }\end{array}$ & $\begin{array}{l}\text { Drink plenty of water or electrolyte drink. Wear } \\
\text { appropriate clothing. Take occasional breaks and watch } \\
\text { for symptoms of heat exhaustion. Use sun block. }\end{array}$ \\
\hline $\begin{array}{l}\text { Working at field } \\
\text { site }\end{array}$ & Hypothermia or frostbite & $\begin{array}{l}\text { Wear foul-weather gear during winter months. Keep } \\
\text { clothing dry. }\end{array}$ \\
\hline $\begin{array}{l}\text { Working at field } \\
\text { site }\end{array}$ & Snake bites & $\begin{array}{l}\text { Wear appropriate foot and leg protection. Watch path } \\
\text { ahead. Keep area around gage clear of brush. If bitten, } \\
\text { seek immediate medical help. }\end{array}$ \\
\hline
\end{tabular}




\begin{tabular}{|l|l|l|}
\hline $\begin{array}{l}\text { Working at field } \\
\text { site }\end{array}$ & Poisonous plants & $\begin{array}{l}\text { Know how to identify poisonous plants. Wear protective } \\
\text { clothing. Wash and flush exposed areas immediately with } \\
\text { cold water. Wash with degreasing type soap and flush } \\
\text { from skin. Seek medical attention for severe reactions. }\end{array}$ \\
\hline Entering gage house & $\begin{array}{l}\text { Infectious disease or } \\
\text { airborne pollutants; risk } \\
\text { of hantavirus exposure }\end{array}$ & $\begin{array}{l}\text { Watch for bats or rodent nests and droppings. If nest or } \\
\text { droppings are present, do not disturb dust. Gage should be } \\
\text { periodically cleaned to minimize risk of exposure. See } \\
\text { WRD memo dated 10/28/97, "Preventing hantavirus } \\
\text { disease," and OP memo dated 01/94, "Instructions for } \\
\text { preventing hantavirus disease." }\end{array}$ \\
\hline Entering gage house & Insect or snake bites & $\begin{array}{l}\text { Inspect in and around shelter for harmful insects. Use } \\
\text { wasp or insect spray. Inspect in and around shelter for } \\
\text { snakes prior to entry. }\end{array}$ \\
\hline
\end{tabular}

\section{Site-Specific Job Hazards}

The items listed are safety issues (specific to this site) that deserve special emphasis.

- Use caution when placing hands inside metal box containing Sutron datalogger. The two wires (black and red) from the AC terminal box to the transformer are hot (120 VAC). 
Figure 1. Aquilla Lake Sutron 8210 wiring panel.

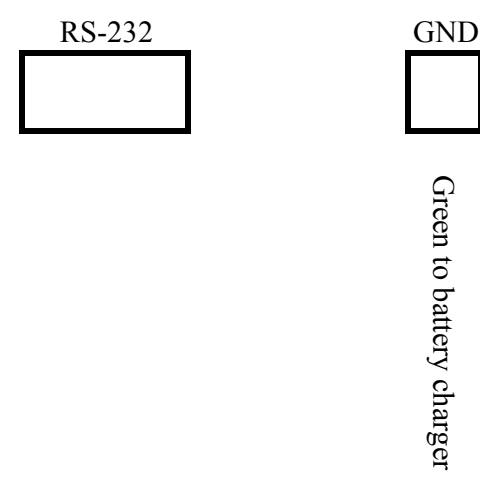

\begin{tabular}{|c|c|c|c|c|c|c|c|c|c|c|c|c|c|c|}
\hline \multicolumn{2}{|c|}{ Ext Batt } & \multicolumn{2}{|c|}{ RS485 } & \multicolumn{3}{|c|}{ SDI-12 } & \multicolumn{3}{|c|}{ SDI-12 } & \multicolumn{5}{|c|}{ Digital Output } \\
\hline $\mathrm{G}$ & + & $\mathrm{A}$ & $\mathrm{B}$ & $\mathrm{G}$ & + & $\mathrm{D}$ & $\mathrm{G}$ & + & $\mathrm{D}$ & 1 & 2 & 3 & 4 & 5 \\
\hline & & & & & & & & & & & & & & \\
\hline 1 & 2 & 3 & 4 & 5 & 6 & 7 & 8 & 9 & 10 & 11 & 12 & 13 & 14 & 15 \\
\hline
\end{tabular}
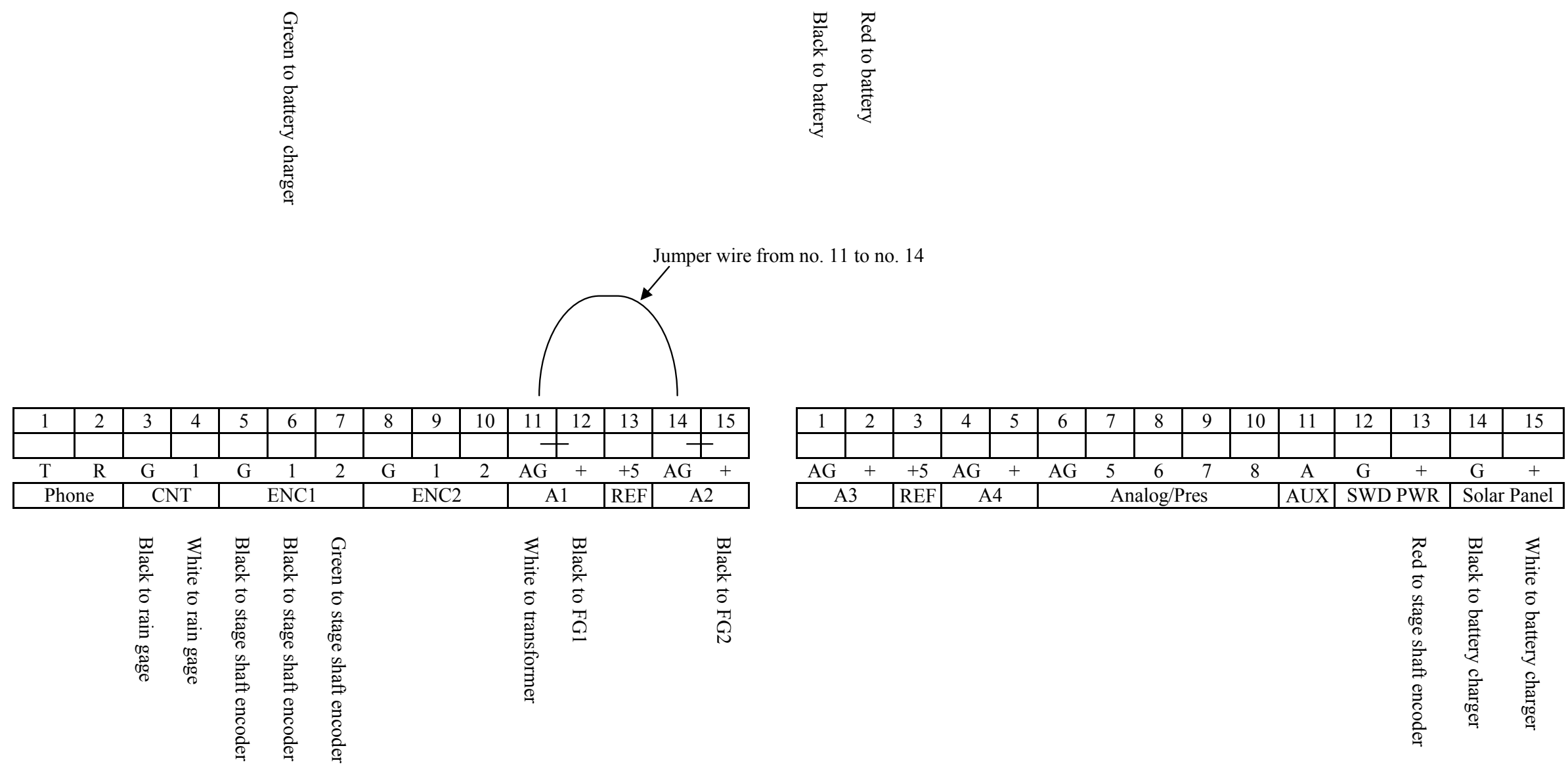

Note: FG1, Floodgate No. 1 or SEVGATE1 (Sutron setup file name). FG2, Floodgate No. 2 or SERGATE2 (Sutron setup file name).

+ denotes a resistor between the two ports of the Sutron. 
Figure 2. Aquilla Lake equipment wiring diagram.
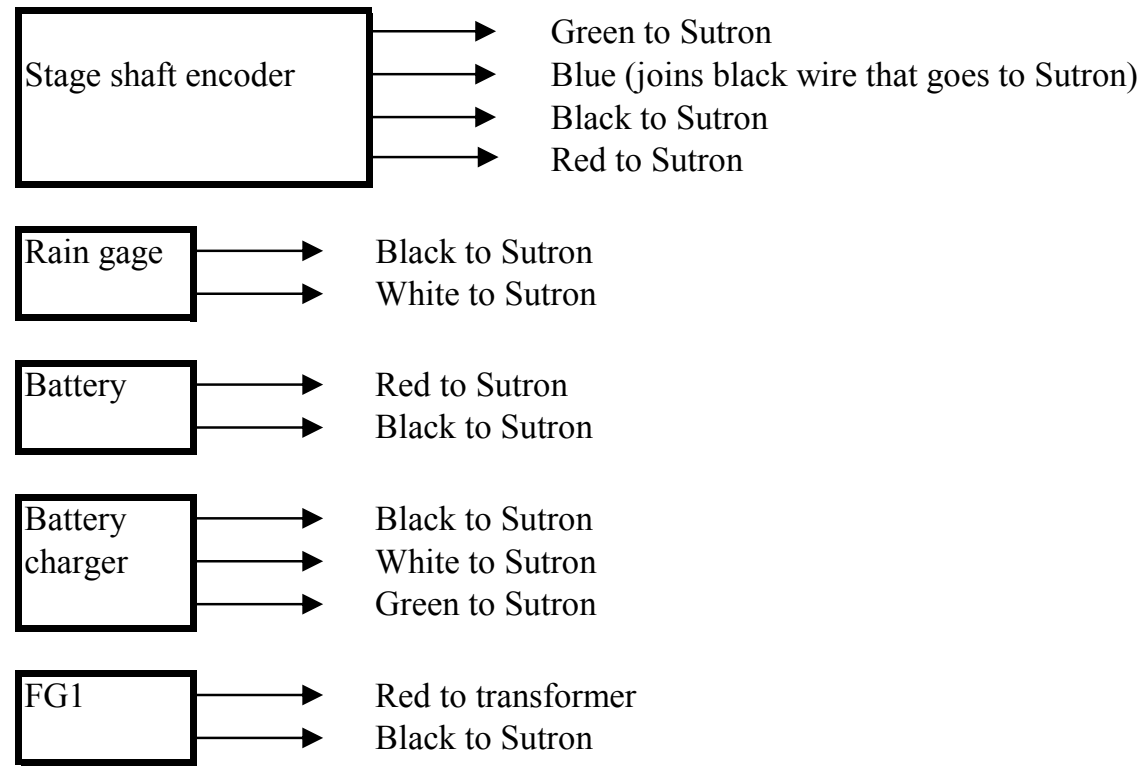

$\begin{array}{ll}\mathrm{FG} 2 & \longrightarrow \\ & \text { Green to transformer } \\ & \text { Black to Sutron }\end{array}$

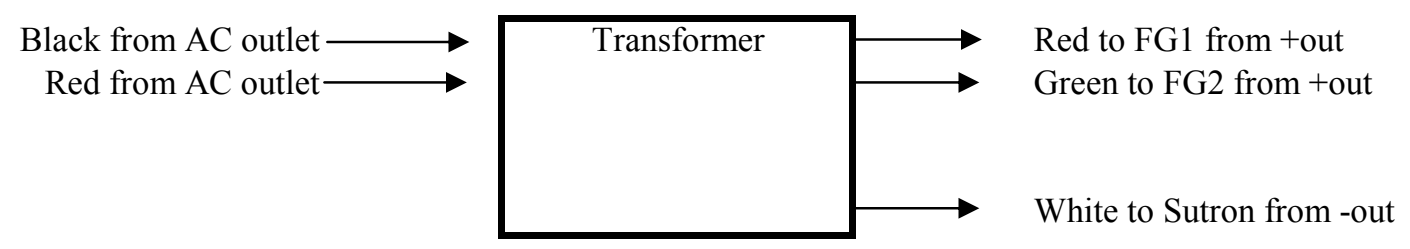

Note: $\quad$ FG1, Floodgate No. 1 or SEVGATE1 (Sutron setup file name).

FG2, Floodgate No. 2 or SERGATE2 (Sutron setup file name). 


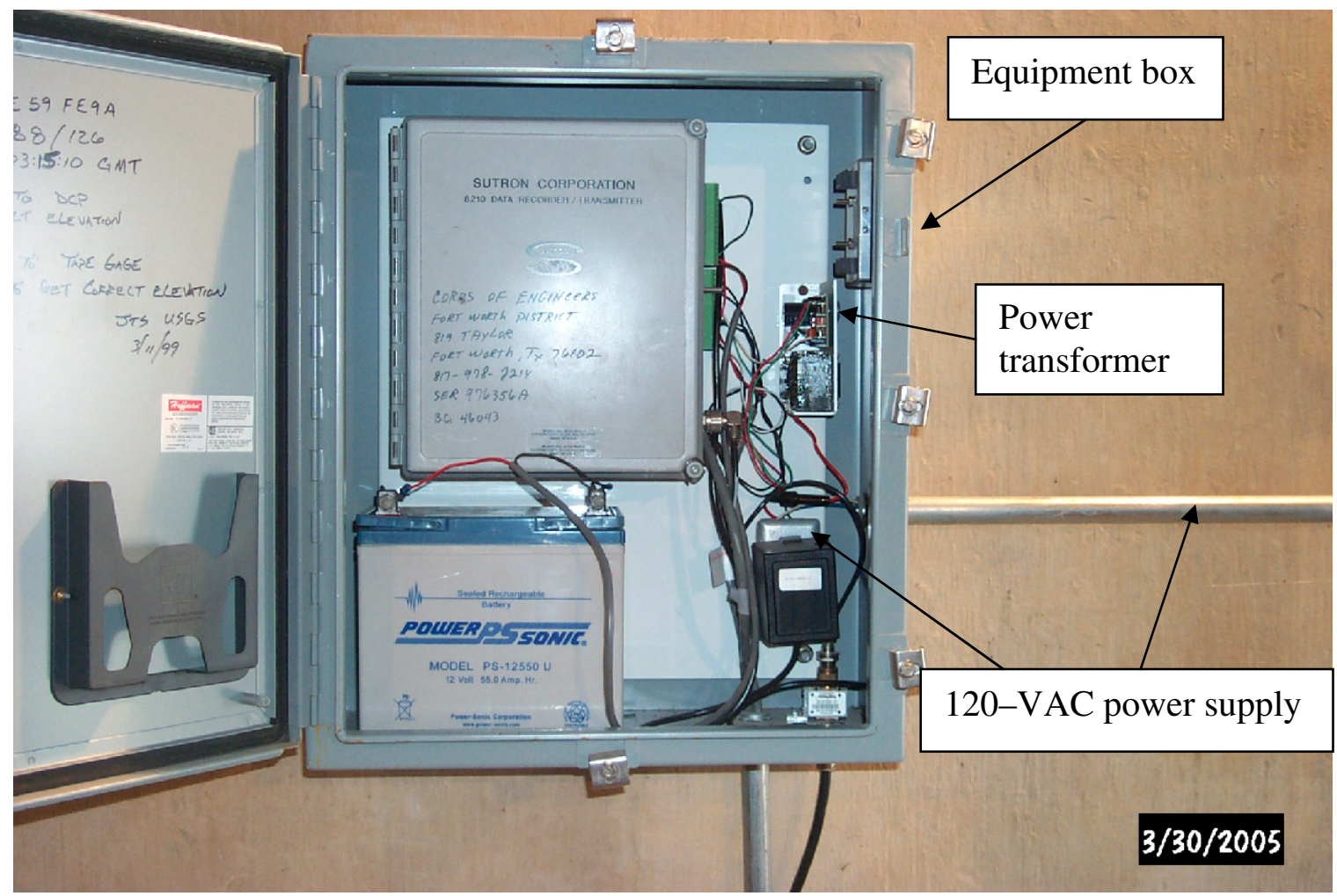

Figure 3. Equipment box at Aquilla Lake.

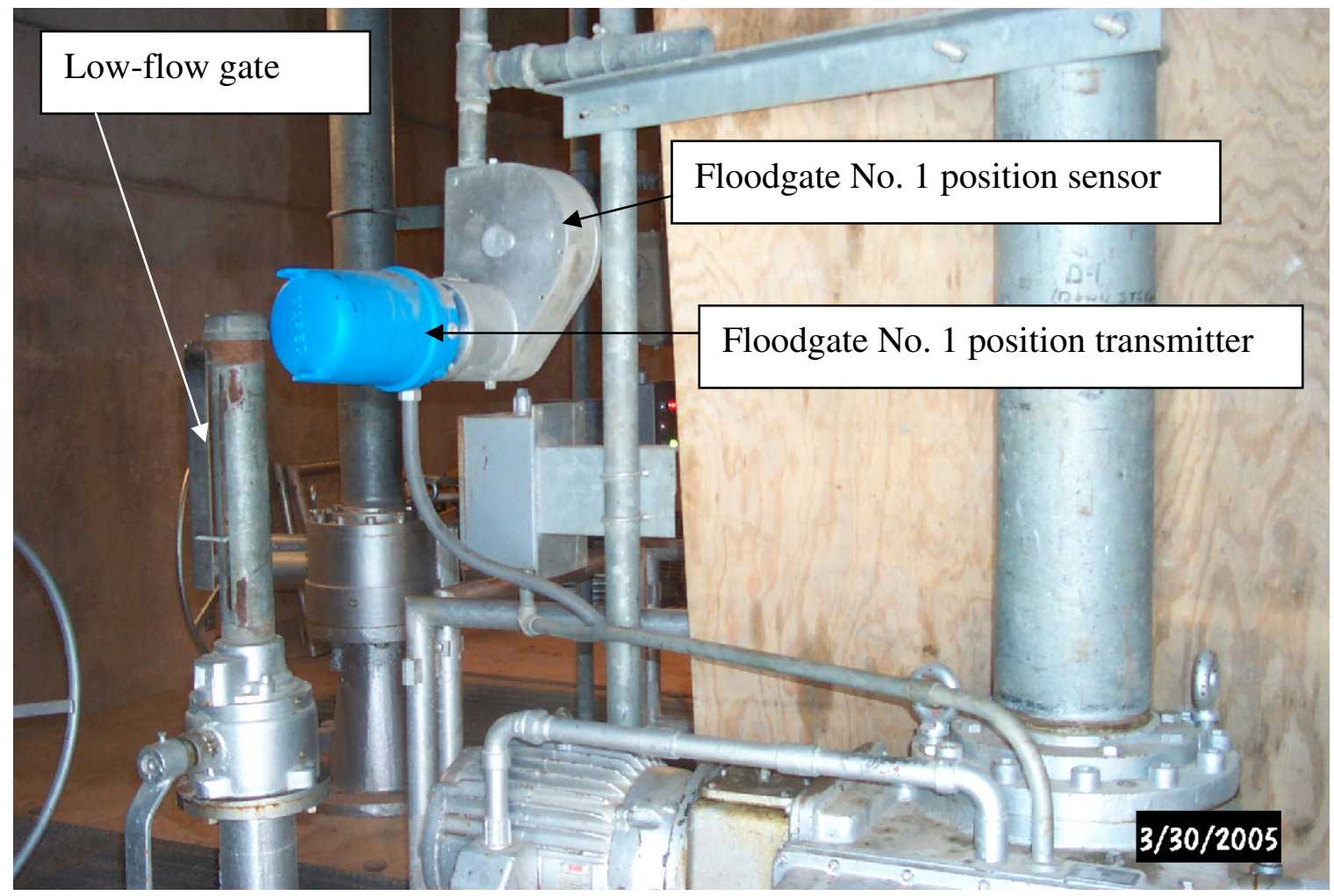

Figure 4. Gate-sensing equipment at Aquilla Lake. 


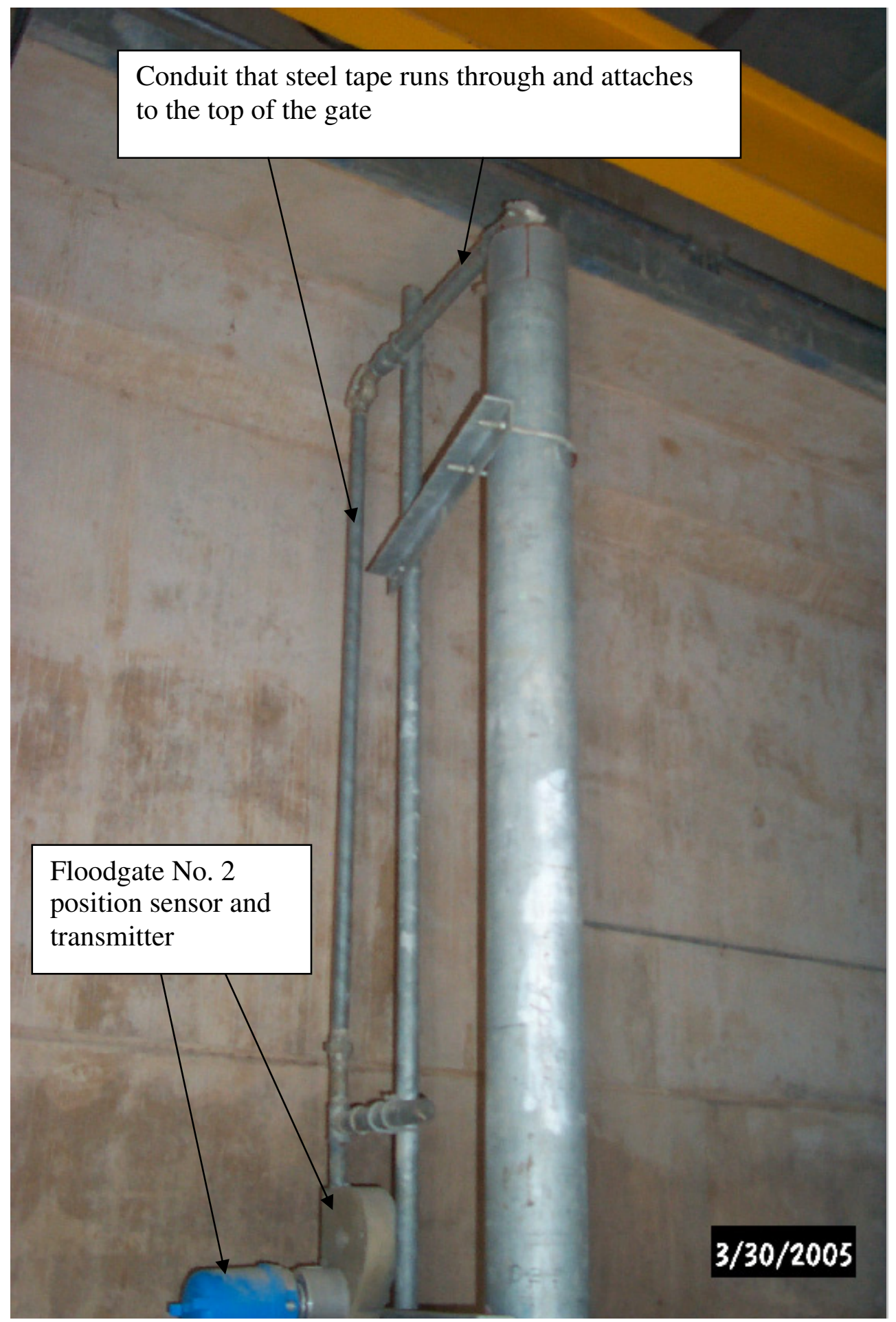

Figure 5. Floodgate No. 2 equipment at Aquilla Lake. 


\section{Aquilla Lake Sutron 8210 Setup File (ALAT2.SET)}

; 8210/8200 ASCII setup file, can be converted back to a .SET file with WSETMGR.EXE

;

; MAIN SETUP

;

Setup_Version $=\mathrm{V} 4 \mathrm{X}$

Unit_ID=ALAT2

Measurement_Interval=00:15:00

Sampling_Interval=00:00:00

Measurement_Time $=00: 00: 00$

Sampling_Time $=00: 00: 00$

Switched_Power_Time $=00: 00: 00$

Samples_to_Average $=10$

Measurements_per_Log $=1$

Switched_Power_Mode $=\mathrm{ON}$

Recording $=\mathrm{ON}$

Basic_Run_Interval=00:00:00

Basic_Run_Time $=00: 00: 00$

Password=

Number_Resets $=21$

Log_Size $=124928$

Rom_Checksum=30925

; EEROM SETUP

Serial_Port_Mode=USER

User_Baud_Rate $=9600$

Radio_Baud_Rate $=9600$

Com_Baud_Rate $=0$

Transfer_Baud_Rate $=9600$

SDI_Baud_Rate $=1200$

Enter_Key_Reqd=ON

Log_Dump_Mode=ALL-BIN

User_Time_Limit $=180$

Power_Delay $=1$

Analog_Delay $=5$

Pressure_Delay $=20$

Auto_Startup_Keys=SSDDDDDDRRDDDDPPPPUPPPPU

Time_Format=NORMAL

Date_Format=MDY

Term_Xmit_Delay $=0$

Basic_Size $=1$

Amp_Gain=1.0

;

; PROTOCOL SETUP

Master_Name=

Carrier_Delay $=7$

Com_Port_Mode=

Reply_Delay $=0$

Ack_Delay $=100$ 


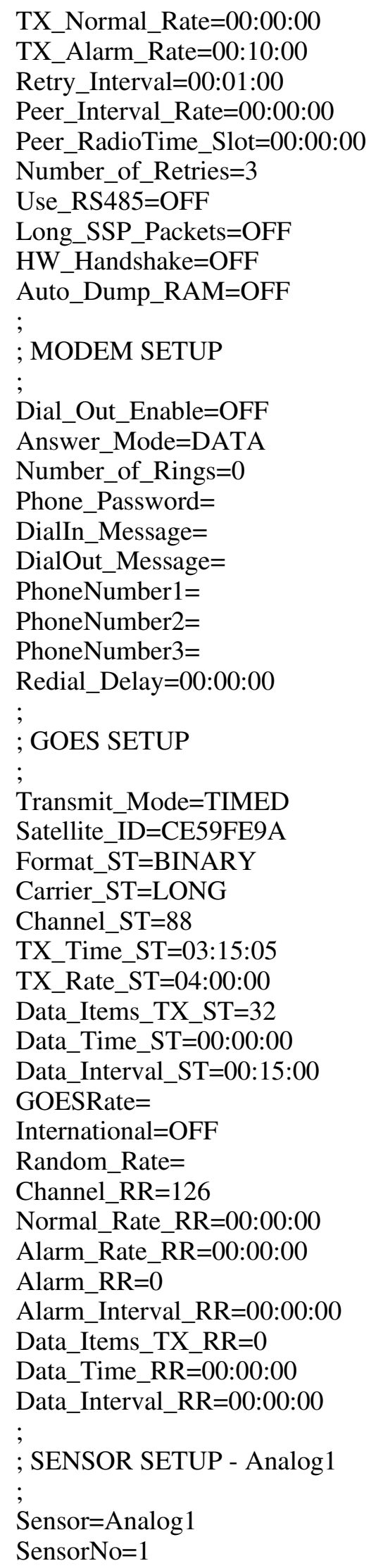




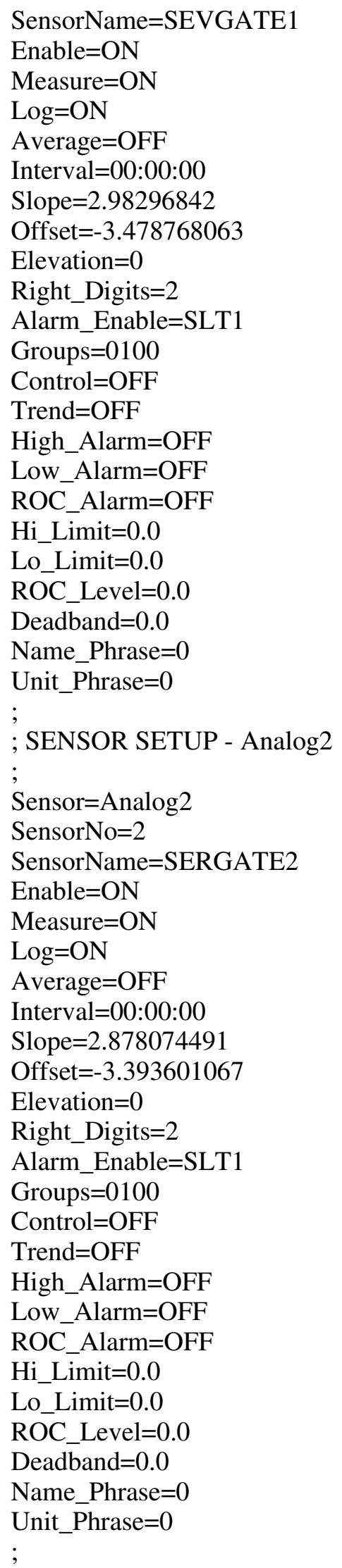




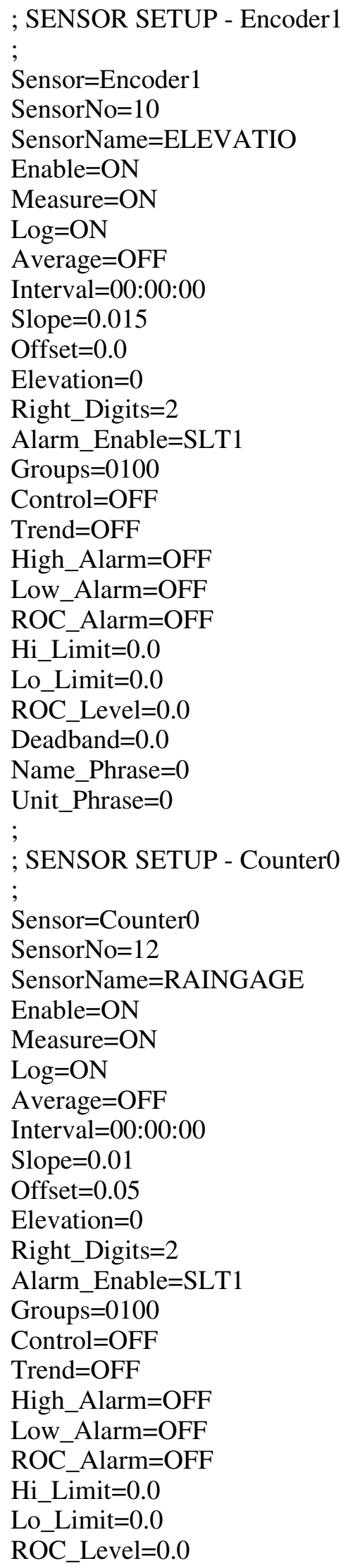


Deadband $=0.0$

Name_Phrase $=0$

Unit_Phrase $=0$

;

; SENSOR SETUP - Battery

;

Sensor=Battery

SensorNo=34

SensorName $=$ BATTERY

Enable $=\mathrm{ON}$

Measure $=\mathrm{ON}$

$\mathrm{Log}=\mathrm{OFF}$

Average $=\mathrm{OFF}$

Interval=00:00:00

Slope $=1.0$

Offset $=0.0$

Elevation $=0$

Right_Digits=1

Alarm_Enable $=\mathrm{ON}$

Groups $=0100$

Control=OFF

Trend=OFF

High_Alarm=OFF

Low_Alarm $=\mathrm{OFF}$

ROC_Alarm $=\mathrm{OFF}$

Hi_Limit $=0.0$

Lo_Limit $=0.0$

ROC_Level $=0.0$

Deadband $=0.0$

Name_Phrase $=0$

Unit_Phrase $=0$ 


\section{Bardwell Lake Near Ennis, Tex.}

\section{Location}

Lat $32^{\circ} 15^{\prime} 00^{\prime \prime}$, long 96 38'49", Ellis County, in intake structure of Bardwell Dam on Waxahachie Creek, 5.0 mi south of Ennis, and 5.6 mi upstream from mouth.

\section{Road Log}

From USGS Texas WSC-Fort Worth, follow I-20 east to SH 287 and exit onto SH 287 south to Ennis. Exit SH 287 to SH 287 Business. Then turn right onto Spur 437 (Clay St.) and travel $1.0 \mathrm{mi}$ to SH 34. Travel south $0.3 \mathrm{mi}$ on SH 34 to Ensign Rd. Turn left onto Ensign Rd. and go $2.7 \mathrm{mi}$ to Observation Road. Turn right onto Observation Road and travel $1.0 \mathrm{mi}$ to the USACE office. From the USACE office, go through the fence that leads to the top of the dam and drive along the top of the dam to the intake structure.

\section{Access}

Before visiting the site, call the Bardwell USACE office at 972-875-5711 to let them know you will be servicing the site. The lock to the fence at the road along the top of the dam and the lock to the intake structure both use a 2640 key. The intake structure is open; therefore, no alarm protects the equipment.

\section{Equipment Description}

Refer to table 2, "Bardwell Lake equipment inventory," for a complete list of equipment and to figures 6-11 for equipment wiring diagrams and photographs of equipment. Two main floodgates and two emergency gates are raised and lowered by Limitorque electric valve operators. The floodgates and the emergency gates are not labeled. They will be referred to as Floodgates No. 1 and 2 and Emergency Gates No. 1 and 2 in this description to be consistent with naming conventions used at other dams. Floodgate No. 1 is on the right side of the intake structure (facing upstream) and Floodgate No. 2 is on the left. Similarly, Emergency Gates No. 1 and No. 2 are on the right and left side (facing upstream), respectively, of the intake structure. The upper deck of the intake structure at Bardwell Lake is open, but there is a roof to protect the equipment from the weather.

The floodgates have position transmitters that are internal to the Limitorque operators to indicate the position of the gates. The position transmitters are resistive sensors that have an output signal of 0 to 5 VDC that is read by the Sutron 5-VDC reference voltage to record the positions. The emergency gates do not have internal resistive sensors; therefore, the position of the gates is not recorded by the datalogger.

Gate-sensing equipment serves as a reference for the two floodgates at Bardwell Dam. On each floodgate is a clear Plexiglas plastic window covering a pointer that moves up and down with movement of the gates. The position of the gates is determined by the position of the pointer on rulers along a pipe. The scale of the rulers is unusualaccording to the operators of the dam, one major tick on the rulers is $0.20 \mathrm{ft}$ of vertical 
displacement of the gates. A window on the Limitorque operators displays a dial that indicates percentage open of the floodgates and emergency gates. The dials vary from 0.0 to 100 percent open, but the dials are not accurate and should not be used as an indication of gate position.

The Sutron 8210 datalogger is powered by a 12-VDC battery, which is charged by a solar panel. The position transmitters are powered by the Sutron 8210 datalogger.

The setup file (BLNE2.SET) for the datalogger is stored on the RAM card that is kept inside the Sutron equipment box. A hard copy of the setup file is also kept in the station folder.

The positions of Floodgates No. 1 and No. 2 are transmitted by satellite and posted on the USACE Web site (http://www.swf-wc.usace.army.mil) under Daily Reports/Gate Sensor Report. The USACE reports hourly data; however, the Sutron datalogger measures and records the gate position for the two gates every 15 minutes.

Floodgates No. 1 and No. 2 are FG1 and FG2, respectively, in the Sutron setup file.

\section{Operation and Maintenance}

Operation and maintenance information for the equipment at Bardwell Dam includes descriptions of different procedures required to maintain equipment such as routine inspections, recalibration of Floodgates No. 1 and No. 2, and annual inspections. The purpose of a site visit and the actions taken should be documented in the logbook kept near the datalogger. Include the date, time, actions, and personnel conducting the site visit in the logbook. This section lists some of the potential problems that might occur with the equipment in service and possible solutions to the problems. Refer to the Operations Manuals for the individual pieces of equipment when further detail is required. The information included here is basic operations and maintenance information.

For each visit to the site, personnel should carry all of the necessary tools required to service the equipment. The tools required to perform all of the tasks listed include the following:

- Screwdrivers, flat and Phillips head

- Crescent wrench, 10-in.

- Box end wrench, 17-mm

- Socket wrench, 17-mm

- Stepladder, $10-\mathrm{ft}$

- Electrical tape

- Digital multimeter

- Pliers

- Ruler

- Laptop computer capable of connecting (with RS-232 port and 9-pin cable) to Sutron 8210

- Sutron 8210 Operations Manual

- Battery load tester

- Spare battery

- Flashlight

- Silicone sealant 


\section{Procedures during a routine inspection}

- Check the enclosure to the Sutron 8210 datalogger for damage and moisture. If moisture is entering the enclosure, seal any openings with silicone.

- Scroll through the VIEW DATA/LIVE READINGS menu and check that the datalogger is making measurements.

- Check the antennas (data and GPS) and make sure connections are secure and waterproofed. Replace electrical tape around connections if old and brittle.

- Check the battery voltage under the LIVE READINGS menu on the Sutron 8210.

- If voltage is low (less than $11.5 \mathrm{~V}$ ), test the battery with a load tester and make sure the voltage remains above the recommended voltage specific to the load tester being used. Replace battery as needed.

- Check the solar panel and make sure it is clean. If not, wipe clean with a damp cloth.

- Verify that the Limitorque position transmitters and the pointers and rulers measure the same values for the positions of Floodgates No. 1 and No. 2. If they measure the same (within $0.03 \mathrm{ft}$ ), no action is required. If the values differ, refer to the recalibration procedures.

- Before leaving the site, make sure the Sutron 8210 is reading ON \& TX under RECORDING.

\section{Procedures to recalibrate Floodgates No. 1 and No. 2}

- Caution: Before executing this procedure, make sure the emergency gates are closed. To calibrate the position transmitters and the Sutron, first record the current slope and offset for the gate being calibrated. Next, set the slope and the offset to 1.00 and 0.00 , respectively. With the gate still completely closed, scroll down to SYSTEM SETUP. Press the right arrow once and scroll down to CONFIG SENSORS. Press the right arrow once and scroll down to the gate that is being calibrated. With the correct gate selected, press the right arrow once and scroll down to VALUE. Enter the correct value, which would be 0.00 , then press the SET button. Next, open the gate as much as possible so that the instrument will be calibrated over the entire range of gate positions. With the gate open as much as possible, enter the value from the pointers and ruler into the VALUE field and press the SET button. From the two known positions entered, the datalogger will calculate the slope and the offset.

- Verify that the position transmitter and the Sutron 8210 datalogger are now measuring the same position as the pointer and ruler (within $0.03 \mathrm{ft}$ ) with the gate open as much as possible. After verification, close the gate completely and check that both measure 0.00 with the gate completely closed. If so, the calibration is complete; if not, perform the calibration again.

- Whenever a change is made to the setup file in the datalogger, download the new file to the RAM card kept at the site. To do this, insert the RAM card into the socket and turn on the 8210. Scroll down to the DUMP DATA menu. Press the right arrow once, then press the down arrow until WRITE CARD SETUP is displayed. Press the SET button and wait for the file to be transferred from the datalogger to the RAM card. To transfer the file from the RAM card to the datalogger, scroll down to the DUMP DATA menu. Press the right arrow once, 
then press the down arrow until READ CARD SETUP is displayed. Press the right arrow to access the setup file. Transfer the selected file to the datalogger by pressing the SET button.

- Record changes to the slope or the offset in the logbook.

\section{Procedures during an annual inspection}

- During an inspection the emergency gates are lowered, and the floodgates are raised all the way up and cleaned and inspected. As the gates are lowered after being serviced, check that the datalogger and the pointers measure the same values. If not, follow the instructions on how to recalibrate the instruments.

- After the inspection, follow all of the procedures for a routine inspection. 
Table 2. Bardwell Lake equipment inventory.

[See table of contents for abbreviated units; --, not available or not applicable]

\begin{tabular}{|c|c|c|c|c|}
\hline Item no. & Item description & Manufacturer & Model no. & Remarks \\
\hline 1. & $\begin{array}{l}\text { Floodgate No. } 1 \text { position } \\
\text { sensor }\end{array}$ & Limitorque & Unit B320-70 & Gate is FG1 in Sutron setup; equipment is not labeled \\
\hline 2. & $\begin{array}{l}\text { Floodgate No. } 1 \text { position } \\
\text { transmitter }\end{array}$ & Limitorque & -- & $\begin{array}{l}\text { Transmitter inside sensor unit and not visible; resistive } \\
\text { sensor }(1,000 \text { ohms }) \text { with output of } 0 \text { to } 5 \mathrm{~V}\end{array}$ \\
\hline 3. & $\begin{array}{l}\text { Wire for position transmitter } \\
\text { No. } 1\end{array}$ & & -- & $25 \mathrm{ft}$ of $18 \mathrm{AWG} / 5$ wires but only 3 wires are used \\
\hline 4. & $\begin{array}{l}\text { Floodgate No. } 2 \text { position } \\
\text { sensor }\end{array}$ & Limitorque & Unit B320-70 & Gate is FG2 in Sutron setup; equipment is not labeled \\
\hline 5. & $\begin{array}{l}\text { Floodgate No. } 2 \text { position } \\
\text { transmitter }\end{array}$ & Limitorque & -- & $\begin{array}{l}\text { Transmitter inside sensor unit and not visible; resistive } \\
\text { sensor }(1,000 \text { ohms) with output of } 0 \text { to } 5 \mathrm{~V}\end{array}$ \\
\hline 6. & $\begin{array}{l}\text { Wire for position transmitter } \\
\text { No. } 2\end{array}$ & -- & -- & $25 \mathrm{ft}$ of $18 \mathrm{AWG} / 5$ wires but only 3 wires are used \\
\hline 7. & Stage shaft encoder & Handar & $436 \mathrm{~A}$ & -- \\
\hline 8. & Rain gage & $\begin{array}{l}\text { Texas Electronics, } \\
\text { Inc. }\end{array}$ & TR-525I & -- \\
\hline 9. & Datalogger & Sutron & 8210 & -- \\
\hline 10. & Battery & Power Sonic & PS-12550U & $12-\mathrm{V}, 55.0-\mathrm{A}-\mathrm{h}$ battery for Sutron 8210 \\
\hline 11. & Solar panel & BP Solar & SX20M & 20-W maximum output \\
\hline 12. & Voltage regulator & $\begin{array}{l}\text { ASC Specialty } \\
\text { Concepts, Inc. }\end{array}$ & ASC $12 / 4$ & $\begin{array}{l}\text { 12-V, 4.0-A voltage regulator to charge battery from solar } \\
\text { panel }\end{array}$ \\
\hline 13. & Antenna & Sutron & YAGI & $402 \mathrm{MHz}$ \\
\hline 14. & Antenna cable & Beldon & $8237 \mathrm{RG} 8 / \mathrm{U}$ & 16-ft cable from Sutron 8210 to antenna \\
\hline 15. & Data transmitter & Sutron & Satlink & -- \\
\hline 16. & GPS antenna & Trimble & Miniature 5V & Magnetic mount on side of shelter \\
\hline 17. & GPS antenna cable & Trimble & -- & Cable comes with antenna \\
\hline
\end{tabular}




\section{Job Hazard Analysis}

Required protective clothing, safety equipment, and supplies: Personal flotation device (PFD), reflective vest, gloves, steel-toed shoes, waders, cell phone, first aid kit, fire extinguisher, rotating or strobe type emergency lights, drinking water.

\begin{tabular}{|c|c|c|}
\hline $\begin{array}{l}\text { Sequence of basic } \\
\text { job steps }\end{array}$ & $\begin{array}{l}\text { Potential } \\
\text { accident or hazard }\end{array}$ & Recommended safe job procedures \\
\hline $\begin{array}{l}\text { Upon job } \\
\text { assignment }\end{array}$ & $\begin{array}{l}\text { Water-related accident or } \\
\text { injury }\end{array}$ & $\begin{array}{l}\text { Employees working in and around water must receive } \\
\text { training specified in WRD Memo 2000.10, "Policy for } \\
\text { safety training associated with over-water activities." }\end{array}$ \\
\hline $\begin{array}{l}\text { Loading and } \\
\text { unloading } \\
\text { equipment }\end{array}$ & $\begin{array}{l}\text { Pinched fingers, mashed } \\
\text { toes, or strained back }\end{array}$ & $\begin{array}{l}\text { Be aware of hand placement. Wear protective gloves and } \\
\text { steel-toed shoes. Use proper lifting techniques. Lift with } \\
\text { legs. Use extra caution lifting heavy sounding weights. }\end{array}$ \\
\hline $\begin{array}{l}\text { Driving to and } \\
\text { returning from work } \\
\text { site }\end{array}$ & $\begin{array}{l}\text { Traffic accidents, vehicle } \\
\text { flooding, or drowning }\end{array}$ & $\begin{array}{l}\text { Drivers of USGS vehicles must have Drivers Safety } \\
\text { Training (SM 445-2-H, chap. 16). Be alert to traffic in } \\
\text { area, obey all traffic laws, and reduce speed when weather } \\
\text { conditions are bad. Do not drive across flooded highways } \\
\text { unless water depth and bridge conditions are known to be } \\
\text { safe. }\end{array}$ \\
\hline Parking vehicle & $\begin{array}{l}\text { Personal and vehicle } \\
\text { safety when exiting } \\
\text { vehicle in traffic; bank } \\
\text { collapse or bridge failure }\end{array}$ & $\begin{array}{l}\text { Use rotating or strobe emergency lights, follow site } \\
\text { traffic-control plan, wear DOT Type III reflective vest } \\
\text { when working in or near roadway. Park away from stream } \\
\text { at a safe distance from banks. }\end{array}$ \\
\hline $\begin{array}{l}\text { Set up traffic- } \\
\text { control equipment }\end{array}$ & $\begin{array}{l}\text { Personal and public } \\
\text { safety }\end{array}$ & $\begin{array}{l}\text { Employees working in or near roadways must have Work } \\
\text { Zone Traffic-Control Safety Training. Remain alert to } \\
\text { traffic conditions. }\end{array}$ \\
\hline $\begin{array}{l}\text { Working at field } \\
\text { site }\end{array}$ & Drowning & $\begin{array}{l}\text { Employees are required to wear a PFD when working in, } \\
\text { on, or over any body of water. There are no exemptions } \\
\text { for employees in the Texas WSC. PFDs will be } \\
\text { international orange in color and equipped with reflective } \\
\text { tape in accordance with } 46 \text { CFR } 25.25-15 \text {. Self-inflating } \\
\text { PFDs are not to be worn by employees who have not had } \\
\text { In-Water Safety Training. }\end{array}$ \\
\hline $\begin{array}{l}\text { Working at field } \\
\text { site }\end{array}$ & Trips, slips, and falls & $\begin{array}{l}\text { Follow path clear of obstructions and with minimal slope; } \\
\text { avoid slippery surfaces. Walk cautiously on steep slopes } \\
\text { or paths with loose material. Use appropriate footwear for } \\
\text { the terrain and conditions. Follow the safest, not the } \\
\text { fastest path! }\end{array}$ \\
\hline $\begin{array}{l}\text { Working at field } \\
\text { site }\end{array}$ & $\begin{array}{l}\text { Dehydration, heat } \\
\text { exhaustion, heat stroke, } \\
\text { or sunburn }\end{array}$ & $\begin{array}{l}\text { Drink plenty of water or electrolyte drink. Wear } \\
\text { appropriate clothing. Take occasional breaks and watch } \\
\text { for symptoms of heat exhaustion. Use sun block. }\end{array}$ \\
\hline $\begin{array}{l}\text { Working at field } \\
\text { site }\end{array}$ & Hypothermia or frostbite & $\begin{array}{l}\text { Wear foul-weather gear during winter months. Keep } \\
\text { clothing dry. }\end{array}$ \\
\hline $\begin{array}{l}\text { Working at field } \\
\text { site }\end{array}$ & Snake bites & $\begin{array}{l}\text { Wear appropriate foot and leg protection. Watch path } \\
\text { ahead. Keep area around gage clear of brush. If bitten, } \\
\text { seek immediate medical help. }\end{array}$ \\
\hline
\end{tabular}




\begin{tabular}{|l|l|l|}
\hline $\begin{array}{l}\text { Working at field } \\
\text { site }\end{array}$ & Poisonous plants & $\begin{array}{l}\text { Know how to identify poisonous plants. Wear protective } \\
\text { clothing. Wash and flush exposed areas immediately with } \\
\text { cold water. Wash with degreasing type soap and flush } \\
\text { from skin. Seek medical attention for severe reactions. }\end{array}$ \\
\hline Entering gage house & $\begin{array}{l}\text { Infectious disease or } \\
\text { airborne pollutants; risk } \\
\text { of hantavirus exposure }\end{array}$ & $\begin{array}{l}\text { Watch for bats or rodent nests and droppings. If nest or } \\
\text { droppings are present, do not disturb dust. Gage should be } \\
\text { periodically cleaned to minimize risk of exposure. See } \\
\text { WRD memo dated 10/28/97, "Preventing hantavirus } \\
\text { disease," and OP memo dated 01/94, "Instructions for } \\
\text { preventing hantavirus disease." }\end{array}$ \\
\hline Entering gage house & Insect or snake bites & $\begin{array}{l}\text { Inspect in and around shelter for harmful insects. Use } \\
\text { wasp or insect spray. Inspect in and around shelter for } \\
\text { snakes prior to entry. }\end{array}$ \\
\hline
\end{tabular}

\section{Site-Specific Job Hazards}

The items listed are safety issues specific to this site that deserve special emphasis.

- Disconnect AC power to position transmitters before opening the units.

- Be careful servicing the solar panel or the antenna. They are about $10 \mathrm{ft}$ above the upper deck and require a stepladder to service. 
Figure 6. Bardwell Lake Sutron 8210 wiring panel.
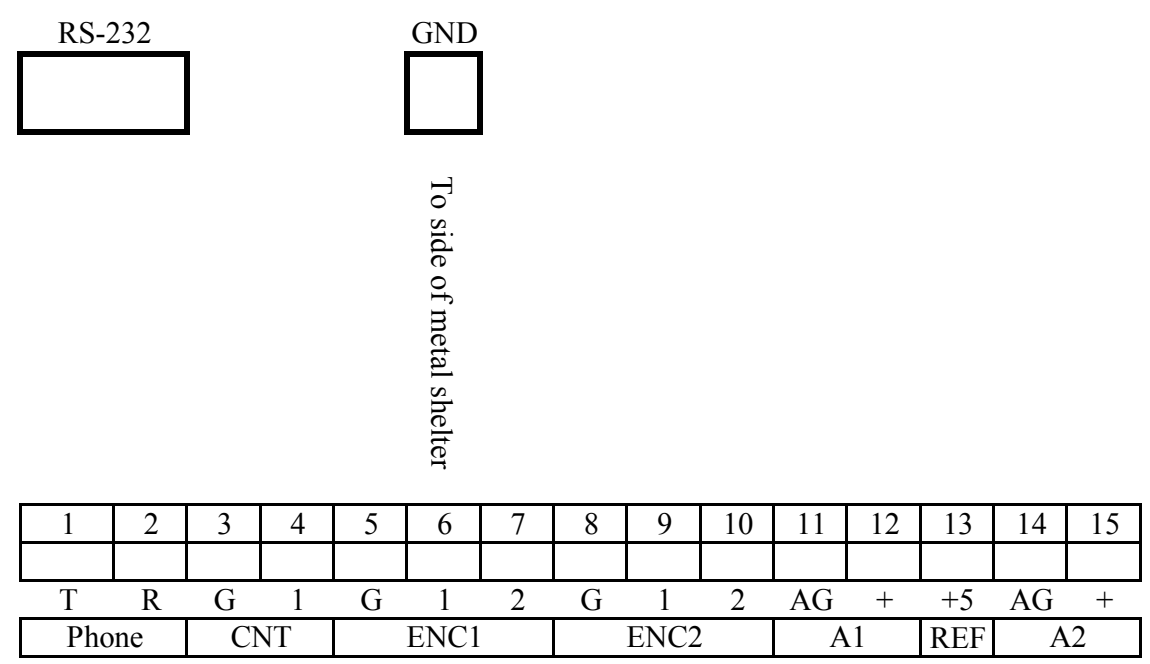

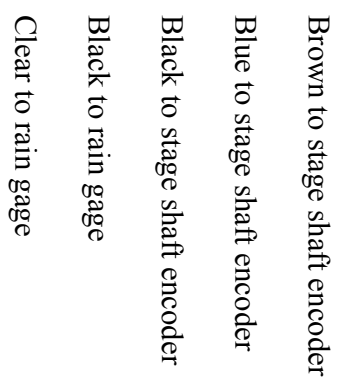

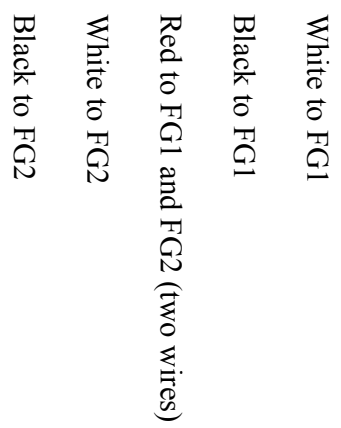

\begin{tabular}{|c|c|c|c|c|c|c|c|c|c|c|c|c|c|c|}
\hline \multicolumn{2}{|c|}{ Ext Batt } & \multicolumn{2}{|c|}{ RS485 } & \multicolumn{3}{|c|}{ SDI-12 } & \multicolumn{3}{|c|}{ SDI-12 } & \multicolumn{5}{|c|}{ Digital Output } \\
\hline $\bar{G}$ & + & $\overline{\mathrm{A}}$ & $\mathrm{B}$ & $\mathrm{G}$ & + & $\bar{D}$ & $\mathrm{G}$ & + & $\mathrm{D}$ & 1 & 2 & 3 & 4 & 5 \\
\hline & & & & & & & & & & & & & & \\
\hline 1 & 2 & 3 & 4 & 5 & 6 & 7 & 8 & 9 & 10 & 11 & 12 & 13 & 14 & 15 \\
\hline
\end{tabular}

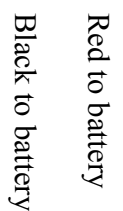

\begin{tabular}{|c|c|c|c|c|c|c|c|c|c|c|c|c|c|c|}
\hline 1 & 2 & 3 & 4 & 5 & 6 & 7 & 8 & 9 & 10 & 11 & 12 & 13 & 14 & 15 \\
\hline $\bar{G}$ & & 55 & & & & & 6 & 7 & 8 & $\bar{a}$ & \multirow{2}{*}{\multicolumn{2}{|c|}{ SWD PWR }} & \multicolumn{2}{|l|}{$\mathrm{G}$} \\
\hline$\frac{A U}{A}$ & & REF & & & & & $\log$ & & & AUX & & & Sola & Panel \\
\hline
\end{tabular}

Note: FG2, Floodgate No. 2

FG1, Floodgate No. 1. 
Figure 7. Bardwell Lake equipment wiring diagram.
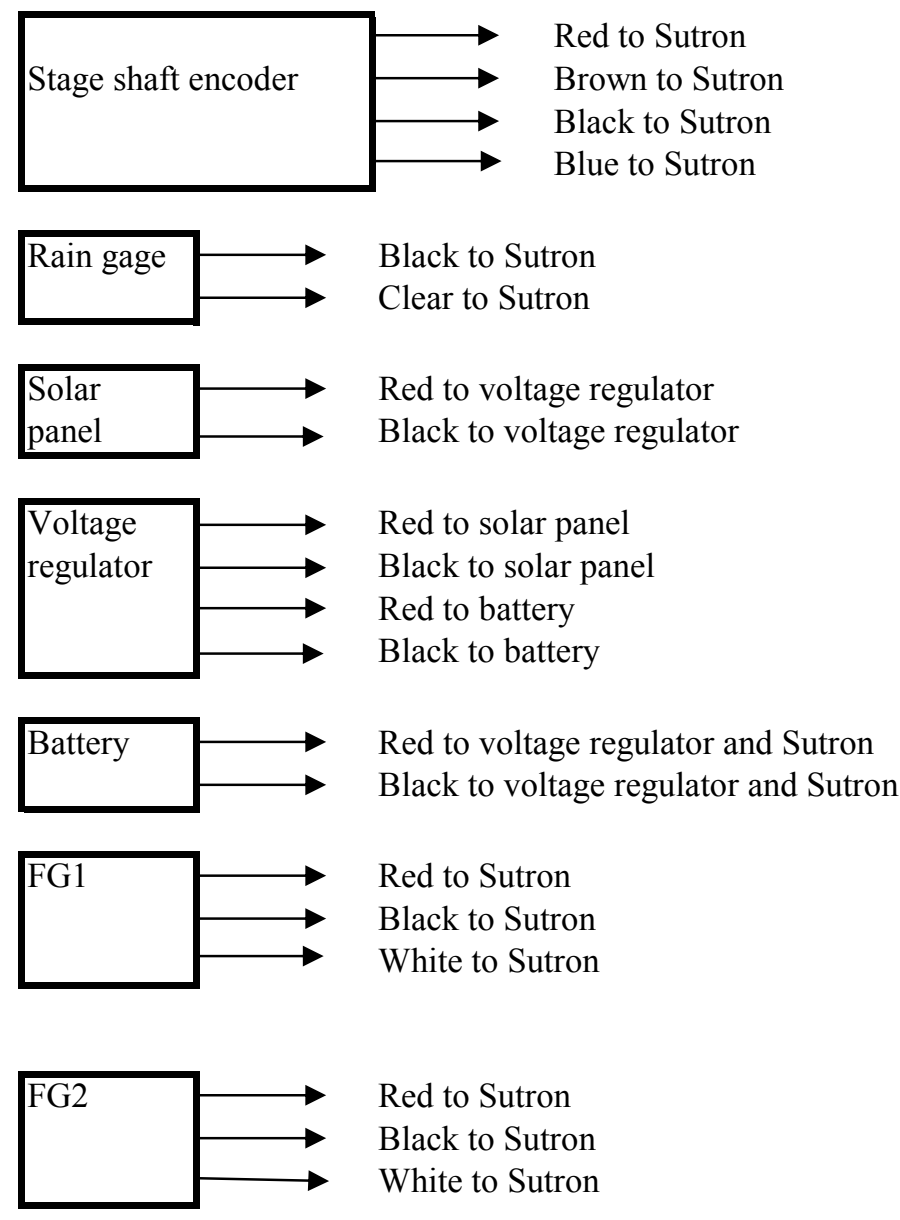

Note: $\quad$ FG1, Floodgate No. 1.

FG2, Floodgate No. 2. 


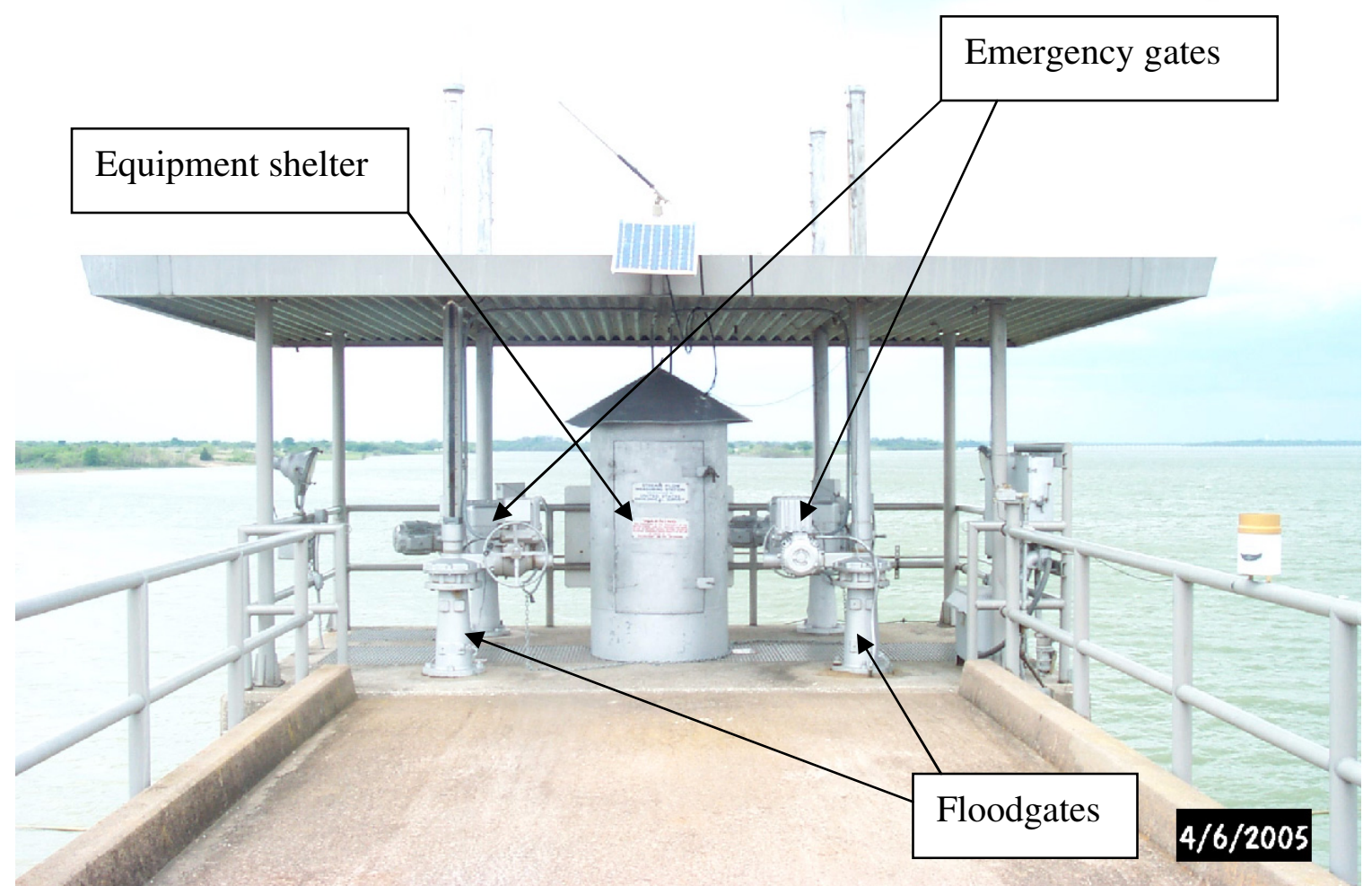

Figure 8. Gate-sensing equipment at Bardwell Lake. 


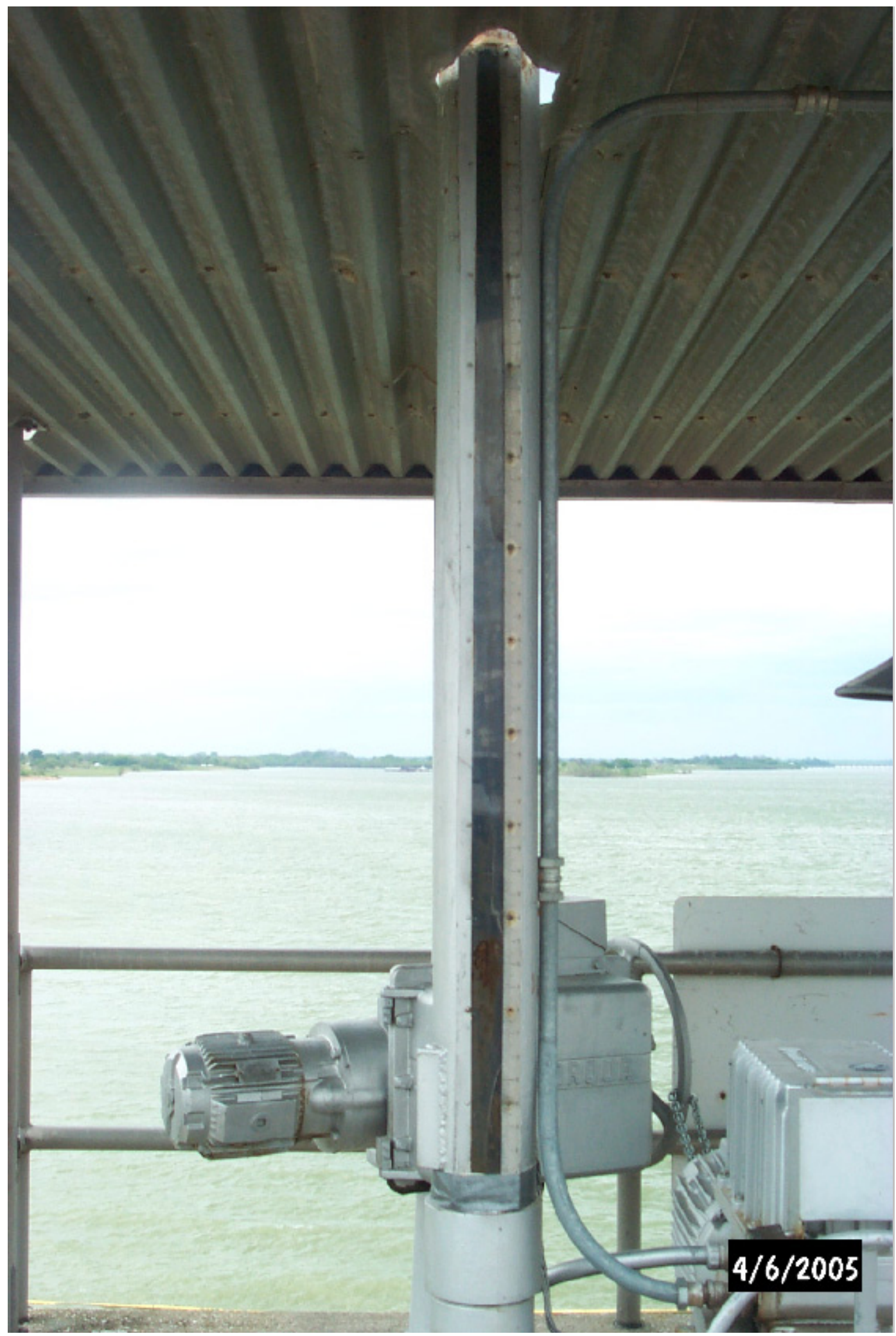

Figure 9. Floodgate No. 2 controls and reference ruler at Bardwell Lake. 


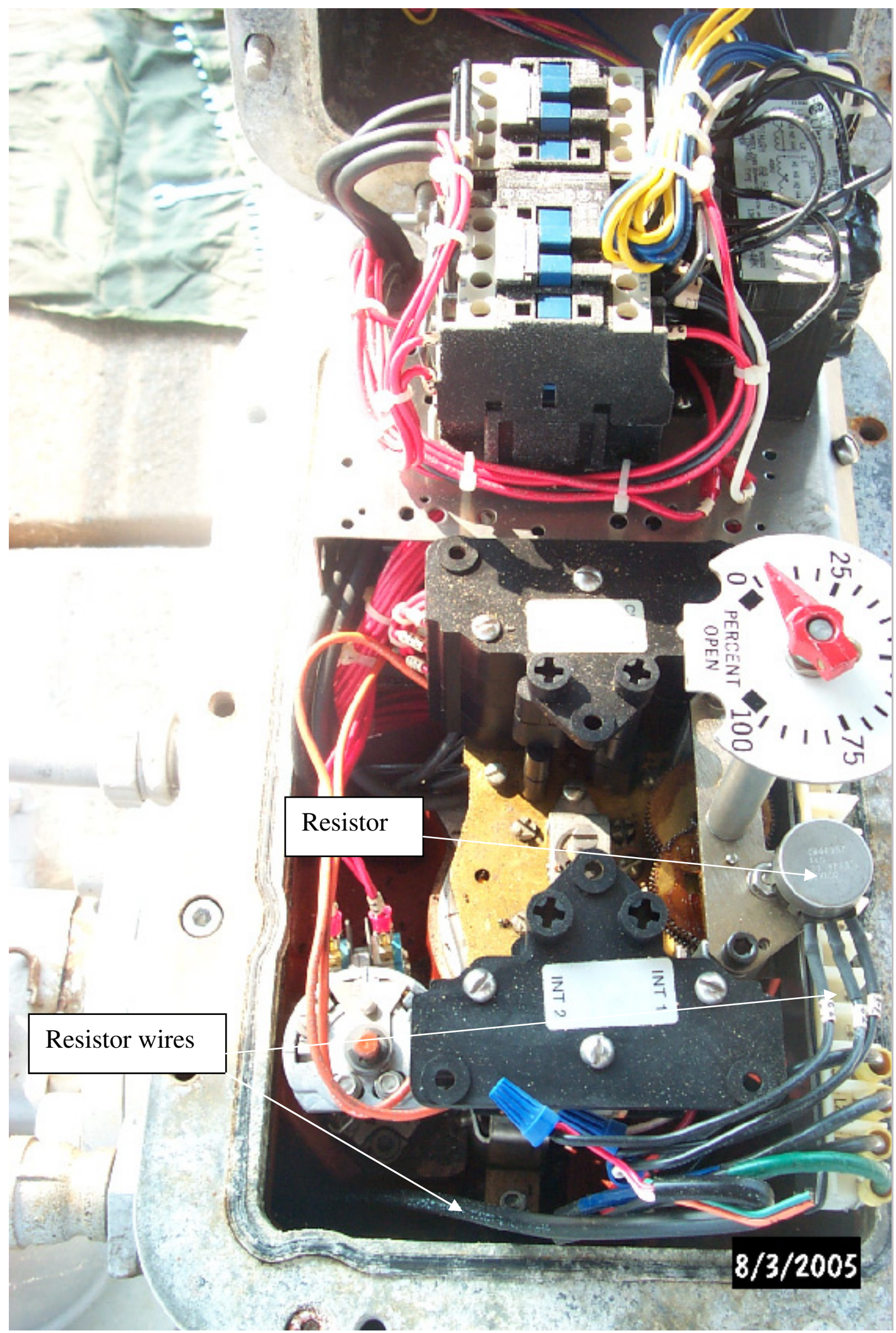

Figure 10. Internal Limitorque resistor at Bardwell Lake. 


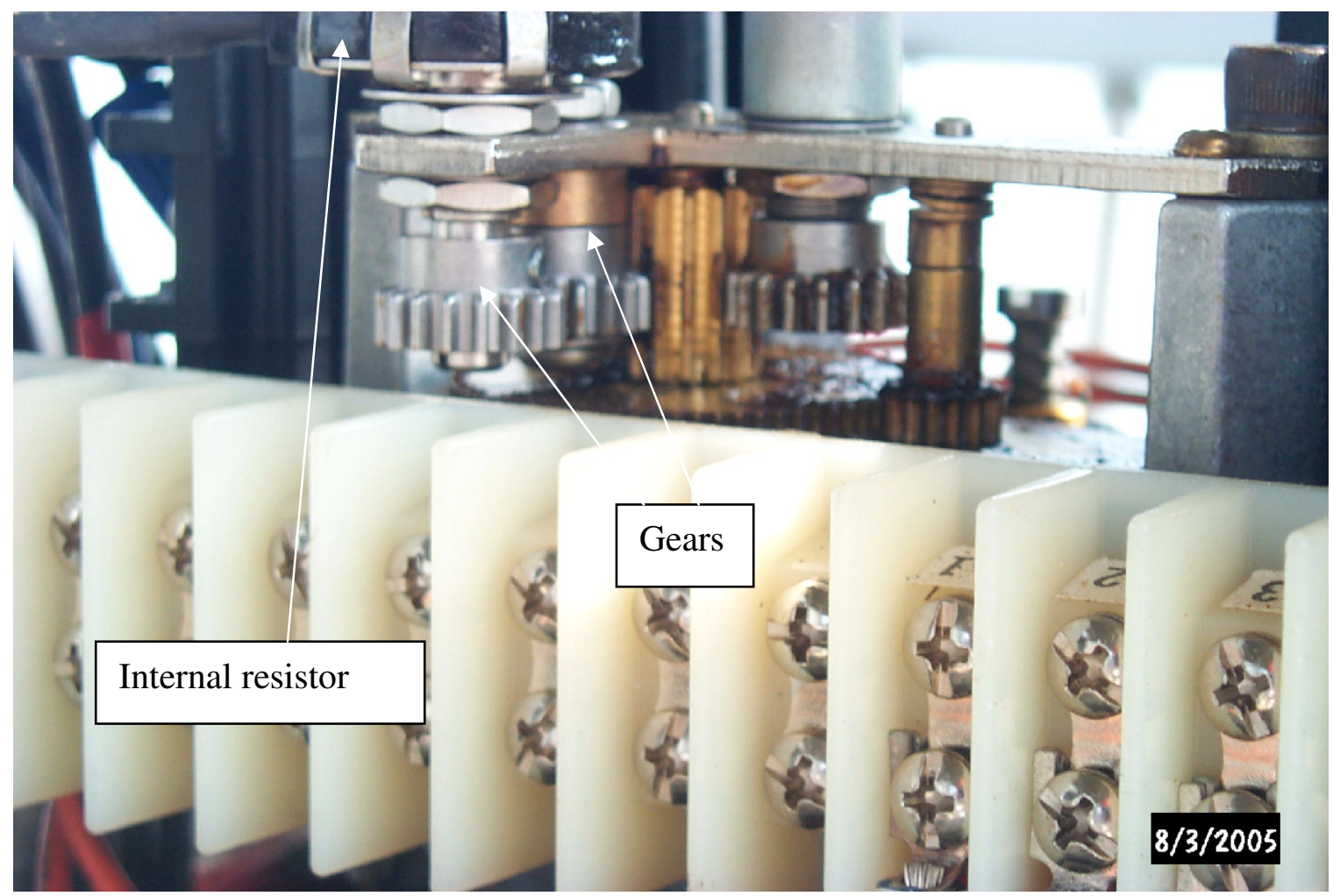

Figure 11. Gears of the Limitorque internal resistor at Bardwell Lake. 


\section{Bardwell Lake Sutron 8210 Setup File (BLNE2.SET)}

; 8210/8200 ASCII setup file, can be converted back to a .SET file with WSETMGR.EXE

;

; MAIN SETUP

;

Setup_Version $=$ V6X

Unit_ID=BLNE2

Measurement_Interval=00:15:00

Sampling_Interval=00:00:00

Measurement_Time $=00: 00: 00$

Sampling_Time $=00: 00: 00$

Switched_Power_Time=00:00:00

Samples_to_Average $=10$

Measurements_per_Log=1

Switched_Power_Mode $=\mathrm{ON}$

Recording $=\mathrm{ON}$

Basic_Run_Interval=00:00:00

Basic_Run_Time $=00: 00: 00$

Password=

Number_Resets $=5$

Log_Size $=124928$

Rom_Checksum=57134

;

; EEROM SETUP

Serial_Port_Mode=USER

User_Baud_Rate $=9600$

Radio_Baud_Rate $=0$

Com_Baud_Rate $=0$

Transfer_Baud_Rate $=9600$

SDI_Baud_Rate $=1200$

Enter_Key_Reqd=ON

Log_Dump_Mode=ALL-BIN

User_Time_Limit $=900$

Power_Delay $=1$

Analog_Delay $=10$

Pressure_Delay $=5$

Auto_Startup_Keys=SSDDDDDDRRDPPPDPPPUU

Time_Format=NORMAL

Date_Format=MDY

Term_Xmit_Delay $=0$

Basic_Size $=1$

Amp_Gain=1.0

;

; PROTOCOL SETUP

Master_Name=

Carrier_Delay $=7$

Com_Port_Mode=

Reply_Delay $=0$

Ack_Delay $=100$ 


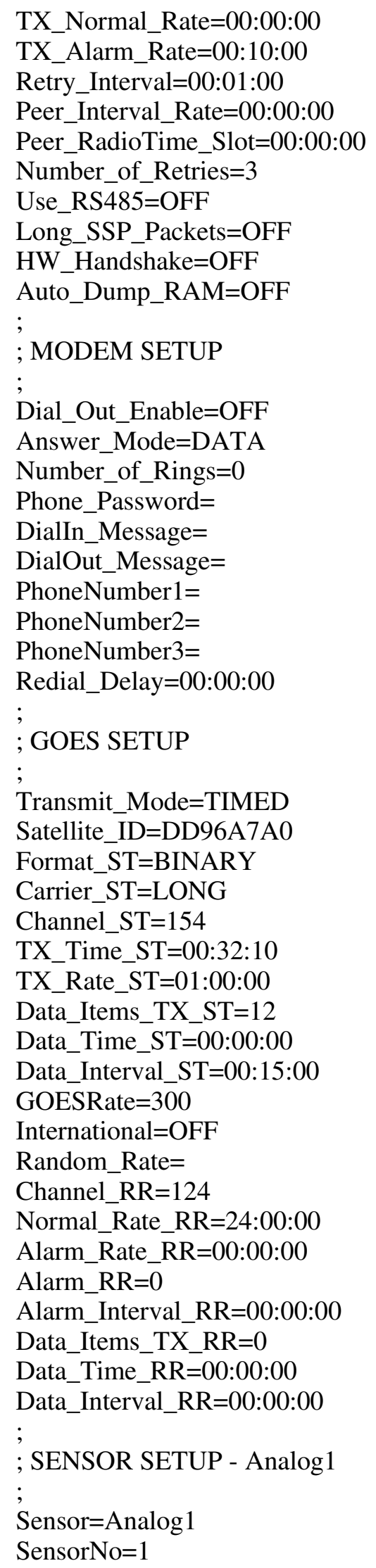




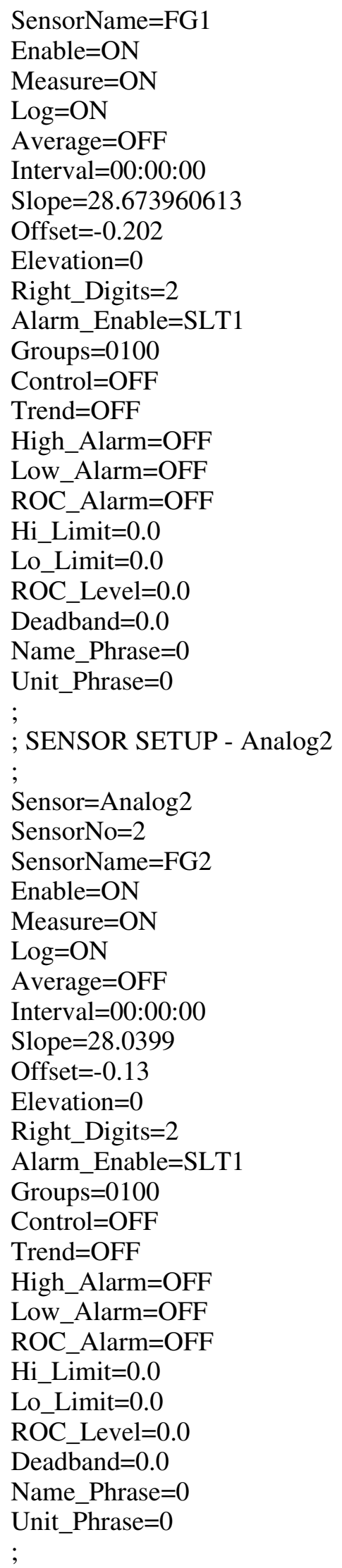




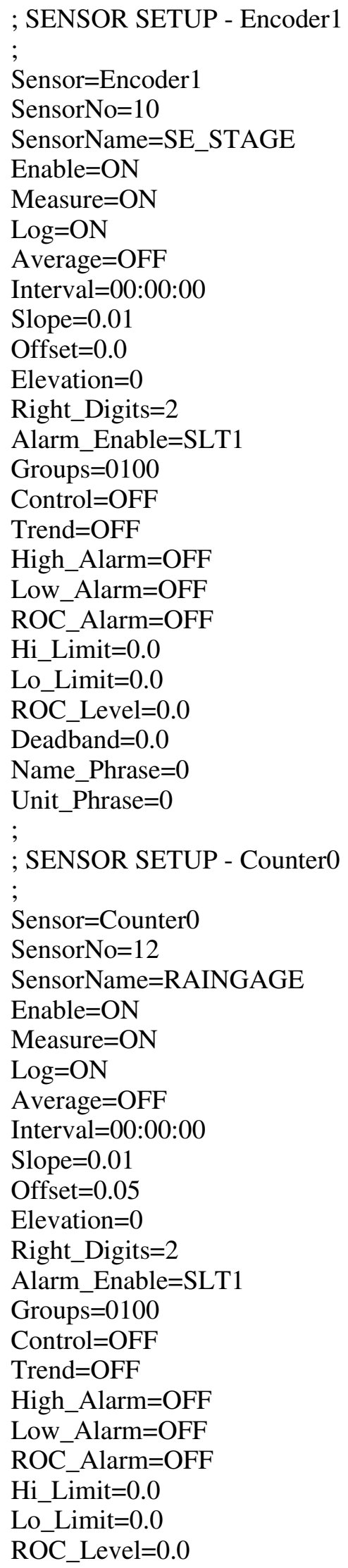


Deadband $=0.0$

Name_Phrase $=0$

Unit_Phrase $=0$

;

; SENSOR SETUP - Battery

;

Sensor=Battery

SensorNo=34

SensorName $=$ BATTERY

Enable $=\mathrm{ON}$

Measure $=\mathrm{ON}$

$\mathrm{Log}=\mathrm{OFF}$

Average $=\mathrm{OFF}$

Interval=00:00:00

Slope $=1.0$

Offset $=0.0$

Elevation $=0$

Right_Digits=1

Alarm_Enable $=\mathrm{OFF}$

Groups $=0000$

Control $=$

Trend $=\mathrm{OFF}$

High_Alarm $=\mathrm{OFF}$

Low_Alarm $=\mathrm{OFF}$

ROC_Alarm $=\mathrm{OFF}$

Hi_Limit $=0.0$

Lo_Limit $=0.0$

ROC_Level $=0.0$

Deadband $=0.0$

Name_Phrase $=0$

Unit_Phrase $=0$ 


\section{Benbrook Lake Near Benbrook, Tex.}

\section{Location}

Lat 32 39'02", long 97²6'54", Tarrant County, in intake structure of Benbrook Dam on Clear Fork Trinity River, 2.5 mi south of Benbrook, 3.5 mi upstream from Mary's Creek, and 14.6 mi upstream from mouth.

\section{Road Log}

From USGS Texas WSC-Fort Worth, take I-20 west to Winscott Rd. exit. Take exit and travel south on Winscott Rd. for about $3.0 \mathrm{mi}$ to Lakeside Dr. Turn left onto Lakeside Dr. and travel east about $2.0 \mathrm{mi}$ to the USACE office. The intake structure is down a restricted access road near the office.

\section{Access}

Before visiting the site, call the Benbrook Dam USACE office at 817-292-2400 to let them know you will be servicing the site. The USACE office has a key to the restricted road gate, the gate on the walkway to the intake structure, and the main door. A USACE staff member will escort you and give you access.

\section{Equipment Description}

Refer to table 3, "Benbrook Lake equipment inventory," for a complete list of equipment and to figures 12-16 for equipment wiring diagrams and photographs of equipment. Two main floodgates (Floodgates No. 1 and No. 2) are raised and lowered by electric motors and cables. Floodgate No.1 is on the right side of the intake structure (facing upstream) and Floodgate No. 2 is on the left.

Each gate has a Celesco VLS9600 series cable-extension transducer and a Schmitz Engineering 24MT series position transmitter, or shaft encoder, that measures the position of the gates. As a gate moves up and down, a stainless steel cable attached to the top of the gate is wound and unwound around a precisely machined, constantdiameter cylindrical spool. The cable is wrapped around the cylinder with a traversing cable guide to create a single layer of wire, thereby preventing inaccuracies associated with a changing spool diameter. The spool is attached to a shaft coupled with a shaft encoder that measures the amount of linear displacement. The VLS9600 cable-extension position transducer is actually a PT9600 instrument with a VLS (velocity limiting system) attached as an option. The VLS limits cable retraction rates to a safe speed to prevent damage caused by accidental free release. The amount of cable on the spool is 1,500 in., or $125 \mathrm{ft}$.

The positions of the two floodgates are displayed on Vorne digital displays above the Sutron 8210 datalogger. Floodgate No. 1 is posted on the left display and Floodgate No. 2 is on the right. Dials to indicate gate position are located on the spools on which the cables are wound and unwound to raise and lower the gates. These dials DO NOT function properly and should NOT be used as references to check the position measured by the other gate-sensing equipment. Furthermore, gate-sensing equipment that serves as 
a reference for the two floodgates is not available at Benbrook Dam. The Celesco units and the Schmitz shaft encoders are assumed to measure the true position of the gates.

Two low-flow gates are on the lower deck of the intake structure. Low-Flow Gate No. 1 is on the right side of the intake structure (facing upstream) and Low-Flow Gate No. 2 is on the left. Low-Flow Gate No. 1 has a Sutron shaft encoder that sends a signal to the Sutron datalogger to indicate gate position. A rod is attached to the gate, and as the gate is raised and lowered the rod travels up and down. A pointer that also moves up and down is attached to the rod and indicates gate position by pointing to a ruler mounted alongside the rod. The pointer and the ruler are assumed to display the true position of the gate; the shaft encoder is set to this reference. A metal tape attached to the top of the rod goes over a pulley attached to the shaft encoder. As the pulley turns, the shaft encoder wheel turns with it and ultimately indicates the amount of linear displacement. This shaft encoder is a quadrature sensor, unlike the two connected to the Celesco transducers, which are SDI12 sensors. Low-Flow Gate No. 2 has a similar setup except that it does not have a shaft encoder attached that communicates the position of the gate to the datalogger. Therefore, the only way to know the position of this gate is to physically read the position of the pointer on the ruler. Unlike the electric motors and cables that open and close the service gates, the low-flow gates are raised and lowered manually with a hand crank. The position of Low-Flow Gate No. 1 is not displayed on the digital display.

The Sutron 8210 datalogger is powered by a 12-VDC battery, which is charged by an automatic sealed lead-acid battery charger connected to a 120-VAC wall outlet. The position transmitters are powered by the Sutron 8210 datalogger through the 12-VDC port (labeled +) on the terminal strip of the Sutron 8210. The data line for the position transmitters are protected from surges caused by lightning or power fluctuations by a data line surge protector manufactured by Citel. A 120-VAC wall outlet powers the digital display.

The setup file (BNBT2.SET) and a basic program file (BNBT2.BAS) for the datalogger are stored on the RAM card that is kept inside the Sutron equipment box. The basic program enables transmission of gate positions from the Sutron datalogger to the Vorne digital displays. A hard copy of the setup file and the basic program file also is kept in the station folder.

The positions of Floodgates No. 1 and No. 2 and Low-Flow Gate No. 1 are transmitted by satellite and posted on the USACE Web site (http://www.swfwc.usace.army.mil) under Daily Reports/Gate Sensor Report. The USACE reports hourly data; however, the Sutron datalogger measures and records the gate position for the three gates every 15 minutes.

Floodgates No. 1 and No. 2 are FG1 and FG2, respectively, in the Sutron setup file and basic program file; Low-Flow Gate No. 1 is LOW1 in the Sutron setup file.

\section{Operation and Maintenance}

Operation and maintenance information for the equipment at Benbrook includes descriptions of different procedures required to maintain equipment such as routine inspections, recalibration of Floodgates No. 1 and No. 2, recalibration of Low-Flow Gate No. 1, and annual inspections. The purpose of a site visit and the actions taken should be documented in the logbook kept near the datalogger. Include the date, time, actions, and personnel conducting the site visit in the logbook. This section lists some of the potential problems that might occur with the equipment in service and possible solutions to the 
problems. Refer to the Operations Manuals for the individual pieces of equipment when further detail is required. The information included here is basic operations and maintenance information.

For each visit to the site, personnel should carry all of the necessary tools required to service the equipment. The tools required to perform all of the tasks listed include the following:

- Screwdrivers, flat and Phillips head

- Allen wrenches, 5/32- and 7/64-in.

- Crescent wrench, 10-in.

- Stepladder, 10-ft

- Electrical tape

- Digital multimeter

- Pliers

- Ruler

- Laptop computer capable of connecting (with RS-232 port and 9-pin cable) to Sutron 8210

- Sutron 8210 Operations Manual

- Battery load tester

- Spare battery

- Flashlight

- Silicone sealant

\section{Procedures during a routine inspection}

- Check the enclosure to the Sutron 8210 datalogger for damage and moisture. If moisture is entering the enclosure, seal any openings with silicone.

- Scroll through the VIEW DATA/LIVE READINGS menu and check that the datalogger is making measurements.

- Check the antennas (data and GPS) and make sure connections are secure and waterproofed. Replace electrical tape around connections if old and brittle.

- Check the battery voltage under the LIVE READINGS menu on the Sutron 8210.

- If voltage is low (less than $11.5 \mathrm{~V}$ ), test the battery with a load tester and make sure the voltage remains above the recommended voltage specific to the load tester being used. Replace battery as needed.

- Check the Vorne digital displays and verify that the displays are reporting the same gate positions as the Sutron 8210 and that display digits are illuminated.

- Verify Floodgates No. 1 and No. 2 position sensors and transmitters are functioning properly by pulling down on the Celesco steel wire a known distance and checking the reading on the display. Hold a ruler flush with the bottom of the Celesco unit. Pull the wire down $1 \mathrm{ft}$ and verify that the Vorne display reads $1 \mathrm{ft}$ less than the current reading. If the actual amount of displacement and the measured amount do not agree, make a note of the difference. Make sure the difference is not caused by inaccuracies associated with trying to pull the wire down a known distance. According to the manufacturer, at $1 \mathrm{ft}$ of displacement the unit is accurate to within $0.0004 \mathrm{ft}$. Do not try to force agreement between the displaced amount and the measured amount by adjusting the slope or the offset in the Sutron 8210 setup. However, check that the slope is set properly to 1.0511 for 
both shaft encoders and adjust if set incorrectly (see "Procedures to Recalibrate Floodgates No. 1 and No. 2"). Check that the connections between the shaft encoders and the Celesco position sensors are good by making sure the Allen screws that connect the two are not loose. Open the cover on the position sensor where the wire enters the unit. Visually check that the wire appears to be winding up uniformly across the wheel and that no kinks are present. Do not try to remove the cylinder that holds the wire. If the wire is pulled down and the shaft encoder does not respond at all (no change in position), check that the SDI12 addresses are set correctly in the Sutron 8210 setup. Floodgates No. 1 and No. 2 should have addresses 1 and 2, respectively. If the slopes are set correctly, the connections and wire appear good, the shaft encoders are responding, and the SDI12 addresses are set correctly, then the shaft encoders or the Celesco position sensors need to be replaced or serviced. Try removing the shaft encoder first and testing it with another Celesco unit known to function properly to try to isolate the problem. If the shaft encoder is good, the Celesco unit should probably be removed and serviced. This will have to be done during an annual inspection. Refer to the "Manufacturer Contact Information" section for address and phone number.

- Check that the Sutron 8210 is reading the same value (within $0.01 \mathrm{ft}$ ) as the pointer and ruler on Low-Flow Gate No. 1. If not, open the box with the shaft encoder and make sure the encoder tape has not come off the pulley. Check that the equipment box does not contain bee or wasp nests, or both, that interfere with rotation. If the tape is not off the pulley and the pulley appears to move freely, recalibrate the shaft encoder by following instructions under "Procedures to recalibrate Low-Flow Gate No. 1."

- Whenever a change is made to the setup file or the basic program in the datalogger, download the new files to the RAM card kept at the site. To do this, insert the RAM card into the socket and turn on the 8210. Scroll down to the DUMP DATA menu. Press the right arrow once, then press the down arrow until WRITE CARD SETUP is displayed. Press the SET button and wait for the files to be transferred from the datalogger to the RAM card. Note that when doing this, both the setup file and the basic program get transferred to the RAM card. To transfer the files from the RAM card to the datalogger, scroll down to the DUMP DATA menu. Press the right arrow once, then press the down arrow until READ CARD SETUP is displayed. Press the right arrow to access the setup file and the basic program. Press the down arrow to select which file to transfer to the datalogger. Transfer the selected file to the datalogger by pressing the SET button. Transfer both the setup file and the basic program.

- Before leaving the site, make sure the Sutron 8210 is reading ON \& TX under RECORDING.

\section{Procedures to recalibrate Floodgates No. 1 and No. 2}

- First make sure that the slope of the shaft encoders is set to 1.0511, as one revolution of the Celesco is 12.613 in. With the gates closed, set the instruments to read zero by adjusting the offset of the Schmitz Engineering shaft encoders.

- To change the offset or the slope, turn on the Sutron 8210 and press the down arrow to SYSTEM SETUP. Press the right arrow once and the down arrow twice to CONFIG SENSORS. Then press the right arrow once and the down arrow to 
select either FG1 or FG2. With the correct shaft encoder selected, press the right arrow once and then the down arrow to slope and offset. Press the SET button once when either slope or offset are highlighted. Change the value using the arrow buttons. Right and left arrow buttons move from one digit to the next. Up and down arrow buttons increase or decrease the value, respectively. When finished, press the SET button to save the new value. Check LIVE READINGS or the digital display to see the new measured value.

- Record changes to the slope or the offset in the logbook and save the new setup file to the RAM card.

\section{Procedures to recalibrate Low-Flow Gate No. 1}

- Lower the gate so that it is closed and the rod and pointer read zero. Set the Sutron shaft encoder to read zero by adjusting the offset in the datalogger setup file. One revolution of the wheel is $1 \mathrm{ft}$; however, the slope should be set to 0.01 to instruct the datalogger to report the measured position to the hundredths place.

- To change the offset or the slope, follow the same instructions as those given for changing the offset or the slope to Floodgates No. 1 and No. 2 except select LOW1 instead of FG1 or FG2.

- Open Low-Flow Gate No. 1 to its previous position (if open) and verify that the Sutron and the rod and pointer read the same.

- Record changes to the slope or the offset in the logbook and save the new setup file to the RAM card.

\section{Procedures during an annual inspection}

- During an inspection the emergency gates are lowered, and the floodgates are raised all the way up into the intake structure where they are cleaned and inspected. As the gates are raised, check and clean the wire as it winds up into the Celesco position sensor. Check the wire for worn areas and clean debris off the wire. If the wire appears substantially damaged do not try to replace the wire. Send the unit to Celesco for service. Refer to the "Manufacturer Contact Information" section for address and phone number.

- When the gates are lowered and closed after being serviced, check that the shaft encoders and datalogger measure zero. If not, follow the instructions to recalibrate the instruments.

- After the inspection, follow all of the procedures for a routine inspection. 
Table 3. Benbrook Lake equipment inventory.

[See table of contents for abbreviated units; --, not available or not applicable]

\begin{tabular}{|c|c|c|c|c|}
\hline $\begin{array}{c}\text { Item } \\
\text { no. }\end{array}$ & Item description & Manufacturer & Model no. & Remarks \\
\hline 1. & Floodgate No. 1 position sensor & Celesco & VLS9600-1500-114-SCH-24MTF & $\begin{array}{l}\text { Gate is FG1 in Sutron setup and equipment is labeled with } \\
\text { numeral } 1\end{array}$ \\
\hline 2. & Floodgate No. 1 position transmitter & Schmitz Engineering & $\begin{array}{l}\text { 24MT-256-4096-SDI12-F-CR6- } \\
\text { 3/8F }\end{array}$ & Shaft encoder with SDI12 address 1 \\
\hline 3. & Wire for position transmitter No. 1 & -- & -- & $\begin{array}{l}24 \text { AWG with three wires going from transmitter to junction } \\
\text { box (A) less than } 1 \mathrm{ft} \text { away }\end{array}$ \\
\hline 4. & $\begin{array}{l}\text { Wire from junction box }(\mathrm{A})^{1} \text { at No. } 1 \text { to } \\
\text { junction box }(\mathrm{C})^{2}\end{array}$ & -- & -- & About $40 \mathrm{ft}$ of $18 \mathrm{AWG} / 3$ wires \\
\hline 5. & Floodgate No. 2 position sensor & Celesco & VLS96001-5001-14-SCH-24MTF & $\begin{array}{l}\text { Gate is FG2 in Sutron setup and equipment is labeled with } \\
\text { numeral } 2\end{array}$ \\
\hline 6. & Floodgate No. 2 position transmitter & Schmitz Engineering & $\begin{array}{l}\text { 24MT-256-4096-SDI12-F-CR6- } \\
\text { 3/8F }\end{array}$ & Shaft encoder with SDI12 address 2 \\
\hline 7. & Wire for position transmitter No. 2 & -- & -- & $\begin{array}{l}24 \text { AWG with three wires going from transmitter to junction } \\
\text { box (B) less than } 1 \mathrm{ft} \text { away }\end{array}$ \\
\hline 8. & $\begin{array}{l}\text { Wire from junction box }(B)^{3} \text { at No. } 2 \text { to } \\
\text { junction box }(\mathrm{C})^{2}\end{array}$ & -- & -- & About $25 \mathrm{ft}$ of $18 \mathrm{AWG} / 3$ wires \\
\hline 9. & Low-Flow Gate No. 1 position sensor & Sutron & $5600-0530$ & Gate is LOW1 in Sutron setup but equipment is not labeled \\
\hline 10. & Wire from Low-Flow Gate No. 1 to Sutron & -- & -- & About $90 \mathrm{ft}$ of $18 \mathrm{AWG} / 4$ wires \\
\hline 11. & Stage shaft encoder & Sutron & $56-0540$ & ELEV in Sutron setup and SDI12 address 3 \\
\hline 12. & Rain gage & Texas Electronics, Inc. & TR-525I & -- \\
\hline 13. & Datalogger & Sutron & 8210 & -- \\
\hline 14. & $\begin{array}{l}\text { Digital displays for Floodgates No. } 1 \text { and } \\
\text { No. } 2\end{array}$ & Vorne Industries & GY2200 & $\begin{array}{l}\text { Connected to Sutron } 8210 \text { through RS-232 9-pin cable (10 ft) } \\
\text { and powered by } 120-\mathrm{VAC} \text { wall outlet }\end{array}$ \\
\hline 15. & Battery & Power Sonic & PS-12550U & $12-\mathrm{V}, 55.0-\mathrm{A}-\mathrm{h}$ battery for Sutron 8210 \\
\hline 16. & Battery charger & Power Sonic & PSC-12800A & $12-\mathrm{V}, 800-\mathrm{mA}$ \\
\hline 17. & Data line surge protector & Citel & B48012D3 & -- \\
\hline 18. & Antenna & -- & -- & Mounted on upstream side of intake structure \\
\hline 19. & Antenna cable & Belden & Shielded CL2X & 45-ft cable from Sutron 8210 to antenna \\
\hline 20. & Data transmitter & Sutron & Satlink & -- \\
\hline 21. & GPS antenna & Trimble & Bullet III & -- \\
\hline 22. & GPS antenna cable & Belden- $\mathrm{T}$ & $1189 \mathrm{~A}$ & 70 -ft cable from Sutron 8210 to antenna \\
\hline
\end{tabular}

Junction box (A) adjacent to Floodgate No. 1 position transmitter.

${ }^{2}$ Junction box (C) adjacent to Sutron 8210 datalogger.

Junction box (B) adjacent to Floodgate No. 2 position transmitter. 


\section{Job Hazard Analysis}

Required protective clothing, safety equipment, and supplies: Personal flotation device (PFD), reflective vest, gloves, steel-toed shoes, waders, cell phone, first aid kit, fire extinguisher, rotating or strobe type emergency lights, drinking water.

\begin{tabular}{|c|c|c|}
\hline $\begin{array}{l}\text { Sequence of basic } \\
\text { job steps }\end{array}$ & $\begin{array}{l}\text { Potential } \\
\text { accident or hazard }\end{array}$ & Recommended safe job procedures \\
\hline $\begin{array}{l}\text { Upon job } \\
\text { assignment }\end{array}$ & $\begin{array}{l}\text { Water-related accident or } \\
\text { injury }\end{array}$ & $\begin{array}{l}\text { Employees working in and around water must receive } \\
\text { training specified in WRD Memo 2000.10, "Policy for } \\
\text { safety training associated with over-water activities. " }\end{array}$ \\
\hline $\begin{array}{l}\text { Loading and } \\
\text { unloading } \\
\text { equipment }\end{array}$ & $\begin{array}{l}\text { Pinched fingers, mashed } \\
\text { toes, or strained back }\end{array}$ & $\begin{array}{l}\text { Be aware of hand placement. Wear protective gloves and } \\
\text { steel-toed shoes. Use proper lifting techniques. Lift with } \\
\text { legs. Use extra caution lifting heavy sounding weights. }\end{array}$ \\
\hline $\begin{array}{l}\text { Driving to and } \\
\text { returning from work } \\
\text { site }\end{array}$ & $\begin{array}{l}\text { Traffic accidents, vehicle } \\
\text { flooding, or drowning }\end{array}$ & $\begin{array}{l}\text { Drivers of USGS vehicles must have Drivers Safety } \\
\text { Training (SM 445-2-H, chap. 16). Be alert to traffic in } \\
\text { area, obey all traffic laws, and reduce speed when weather } \\
\text { conditions are bad. Do not drive across flooded highways } \\
\text { unless water depth and bridge conditions are known to be } \\
\text { safe. }\end{array}$ \\
\hline Parking vehicle & $\begin{array}{l}\text { Personal and vehicle } \\
\text { safety when exiting } \\
\text { vehicle in traffic; bank } \\
\text { collapse or bridge failure }\end{array}$ & $\begin{array}{l}\text { Use rotating or strobe emergency lights, follow site } \\
\text { traffic-control plan, wear DOT Type III reflective vest } \\
\text { when working in or near roadway. Park away from stream } \\
\text { at a safe distance from banks. }\end{array}$ \\
\hline $\begin{array}{l}\text { Set up traffic- } \\
\text { control equipment }\end{array}$ & $\begin{array}{l}\text { Personal and public } \\
\text { safety }\end{array}$ & $\begin{array}{l}\text { Employees working in or near roadways must have Work } \\
\text { Zone Traffic-Control Safety Training. Remain alert to } \\
\text { traffic conditions. }\end{array}$ \\
\hline $\begin{array}{l}\text { Working at field } \\
\text { site }\end{array}$ & Drowning & $\begin{array}{l}\text { Employees are required to wear A PFD when working in, } \\
\text { on, or over any body of water. There are no exemptions } \\
\text { for employees in the Texas WSC. PFDs will be } \\
\text { international orange in color and equipped with reflective } \\
\text { tape in accordance with } 46 \text { CFR } 25.25-15 \text {. Self-inflating } \\
\text { PFDs are not to be worn by employees who have not had } \\
\text { In-Water Safety Training. }\end{array}$ \\
\hline $\begin{array}{l}\text { Working at field } \\
\text { site }\end{array}$ & Trips, slips, and falls & $\begin{array}{l}\text { Follow path clear of obstructions and with minimal slope; } \\
\text { avoid slippery surfaces. Walk cautiously on steep slopes } \\
\text { or paths with loose material. Use appropriate footwear for } \\
\text { the terrain and conditions. Follow the safest, not the } \\
\text { fastest path! }\end{array}$ \\
\hline $\begin{array}{l}\text { Working at field } \\
\text { site }\end{array}$ & $\begin{array}{l}\text { Dehydration, heat } \\
\text { exhaustion, heat stroke, } \\
\text { or sunburn }\end{array}$ & $\begin{array}{l}\text { Drink plenty of water or electrolyte drink. Wear } \\
\text { appropriate clothing. Take occasional breaks and watch } \\
\text { for symptoms of heat exhaustion. Use sun block. }\end{array}$ \\
\hline $\begin{array}{l}\text { Working at field } \\
\text { site }\end{array}$ & Hypothermia or frostbite & $\begin{array}{l}\text { Wear foul-weather gear during winter months. Keep } \\
\text { clothing dry. }\end{array}$ \\
\hline $\begin{array}{l}\text { Working at field } \\
\text { site }\end{array}$ & Snake bites & $\begin{array}{l}\text { Wear appropriate foot and leg protection. Watch path } \\
\text { ahead. Keep area around gage clear of brush. If bitten, } \\
\text { seek immediate medical help. }\end{array}$ \\
\hline
\end{tabular}




\begin{tabular}{|l|l|l|}
\hline $\begin{array}{l}\text { Working at field } \\
\text { site }\end{array}$ & Poisonous plants & $\begin{array}{l}\text { Know how to identify poisonous plants. Wear protective } \\
\text { clothing. Wash and flush exposed areas immediately with } \\
\text { cold water. Wash with degreasing type soap and flush } \\
\text { from skin. Seek medical attention for severe reactions. }\end{array}$ \\
\hline Entering gage house & $\begin{array}{l}\text { Infectious disease or } \\
\text { airborne pollutants; risk } \\
\text { of hantavirus exposure }\end{array}$ & $\begin{array}{l}\text { Watch for bats or rodent nests and droppings. If nest or } \\
\text { droppings are present, do not disturb dust. Gage should be } \\
\text { periodically cleaned to minimize risk of exposure. See } \\
\text { WRD memo dated 10/28/97, "Preventing hantavirus } \\
\text { disease," and OP memo dated 01/94, "Instructions for } \\
\text { preventing hantavirus disease." }\end{array}$ \\
\hline Entering gage house & Insect or snake bites & $\begin{array}{l}\text { Inspect in and around shelter for harmful insects. Use } \\
\text { wasp or insect spray. Inspect in and around shelter for } \\
\text { snakes prior to entry. }\end{array}$ \\
\hline
\end{tabular}

\section{Site-Specific Job Hazards}

The items listed are safety issues specific to this site that deserve special emphasis.

- Be careful removing or installing the Celesco position transmitters or the Schmitz shaft encoders on Floodgates No. 1 and No. 2. The gaps between the spools holding the cable that raises and lowers the gates are a fall hazard.

- Be extremely careful descending the ladder to get to the lower deck of the intake structure to service or check the low-flow gates. The lower deck is about $25 \mathrm{ft}$ below. The ladder is in the corner and to the right (facing upstream) upon entering the intake structure. Before descending, put on the harness and clip into the carabineer. Lower any tools or other equipment (such as a ladder) with the rope. Descend the steps slowly. The cable connected to the carabineer is designed so that if someone were to fall, the cable would stop releasing and prevent a fall much like a seatbelt works in an automobile when pulled suddenly. Don't forget to attach the cable to the ladder at the bottom so it will be available when ascending to the upper level.

- When servicing or checking the shaft encoder on Low-Flow Gate No. 1, use a stepladder (not an extension ladder) about $10 \mathrm{ft}$ tall. The shaft encoder is about 12 $\mathrm{ft}$ from the floor of the lower deck. Be careful opening the equipment box because bee or wasp nests in the box are common. 
Figure 12. Benbrook Lake Sutron 8210 wiring panel.
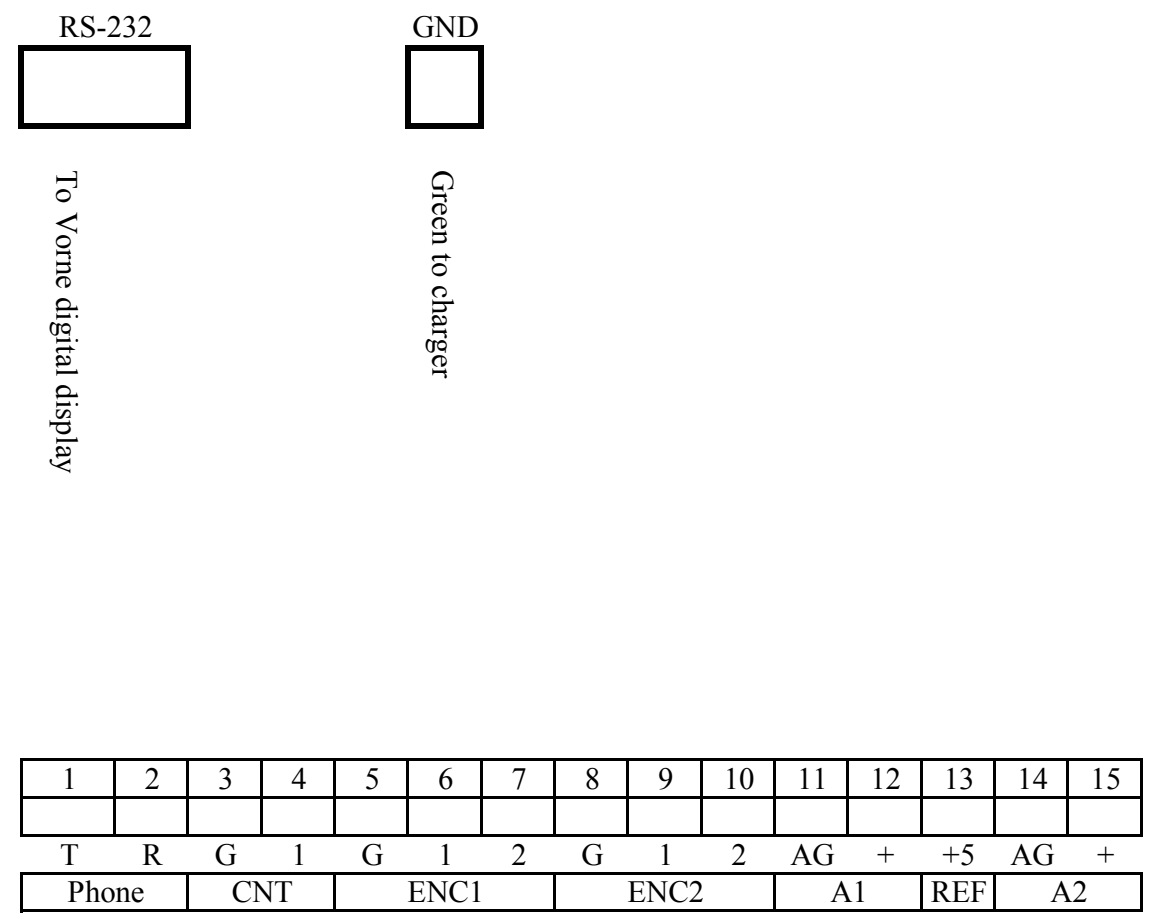

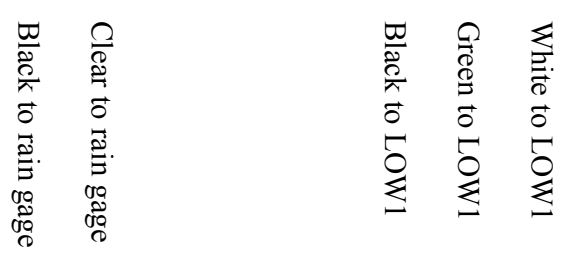

Note: FG1, Floodgate No. 1.

FG2, Floodgate No. 2.

LOW1, Low-Flow Gate No. 1.

\begin{tabular}{|c|c|c|c|c|c|c|c|c|c|c|c|c|c|c|}
\hline \multicolumn{2}{|c|}{ Ext Batt } & \multicolumn{2}{|c|}{ RS485 } & \multicolumn{3}{|c|}{ SDI-12 } & \multicolumn{3}{|c|}{ SDI-12 } & \multicolumn{5}{|c|}{ Digital Output } \\
\hline$\overline{\mathrm{G}}$ & + & $\overline{\mathrm{A}}$ & $\bar{B}$ & $\overline{\mathrm{G}}$ & + & $\bar{D}$ & $\bar{G}$ & + & $\bar{D}$ & 1 & 2 & 3 & 4 & 5 \\
\hline & & & & & & & & & & & & & & \\
\hline 1 & 2 & 3 & 4 & 5 & 6 & 7 & 8 & 9 & 10 & 11 & 12 & 13 & 14 & 15 \\
\hline
\end{tabular}

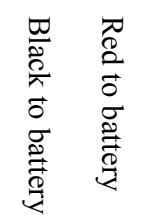

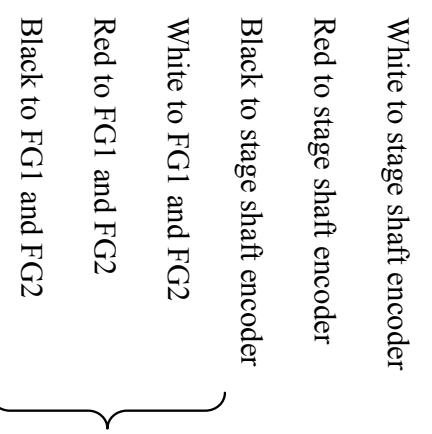

The white data line is wired to

the data line surge protector

before going to transmitters

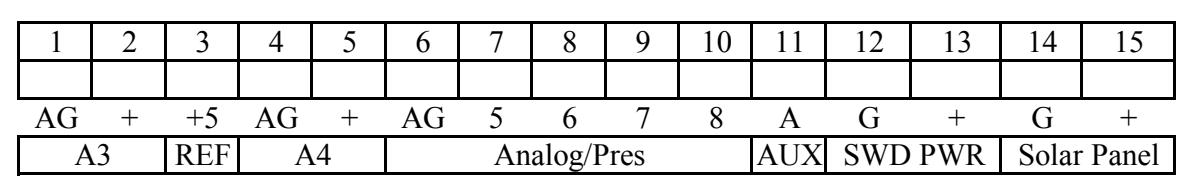

\section{2
0
0
0
0}


Figure 13. Benbrook Lake equipment wiring diagram.
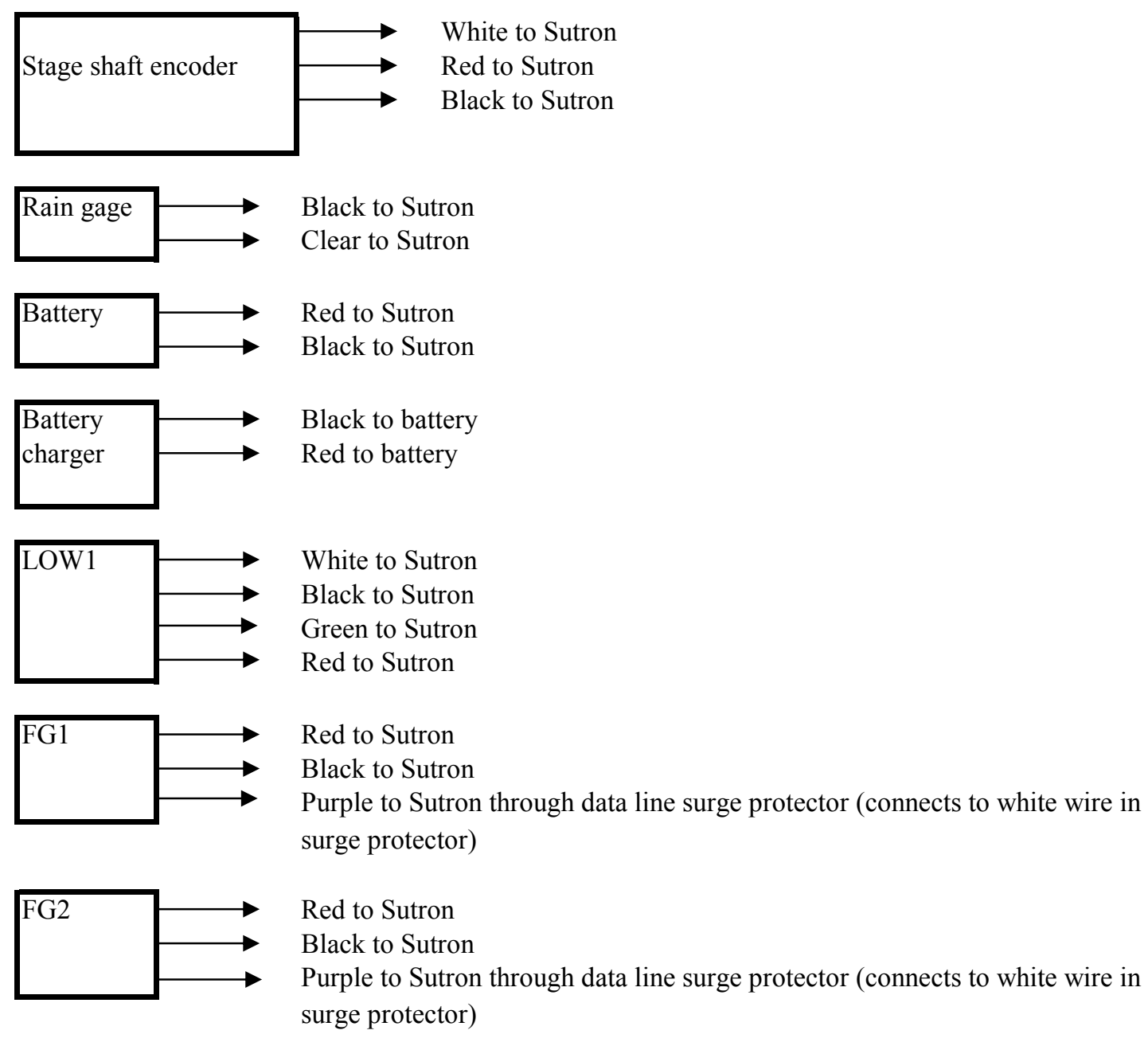

Note: $\quad$ FG1, Floodgate No. 1.

FG2, Floodgate No. 2.

LOW1, Low-Flow Gate No. 1. 


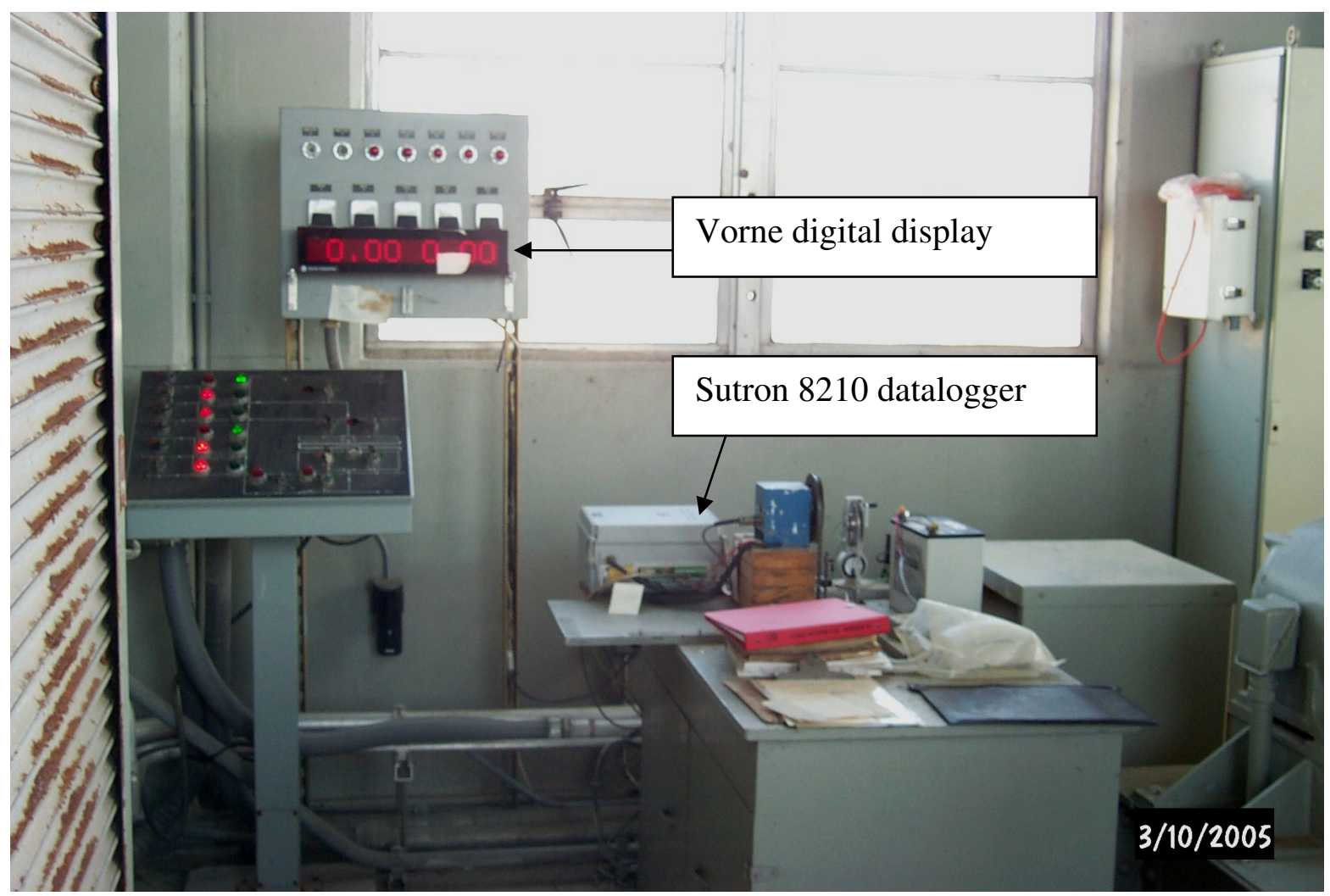

Figure 14. Benbrook Lake Sutron 8210 and digital displays. 


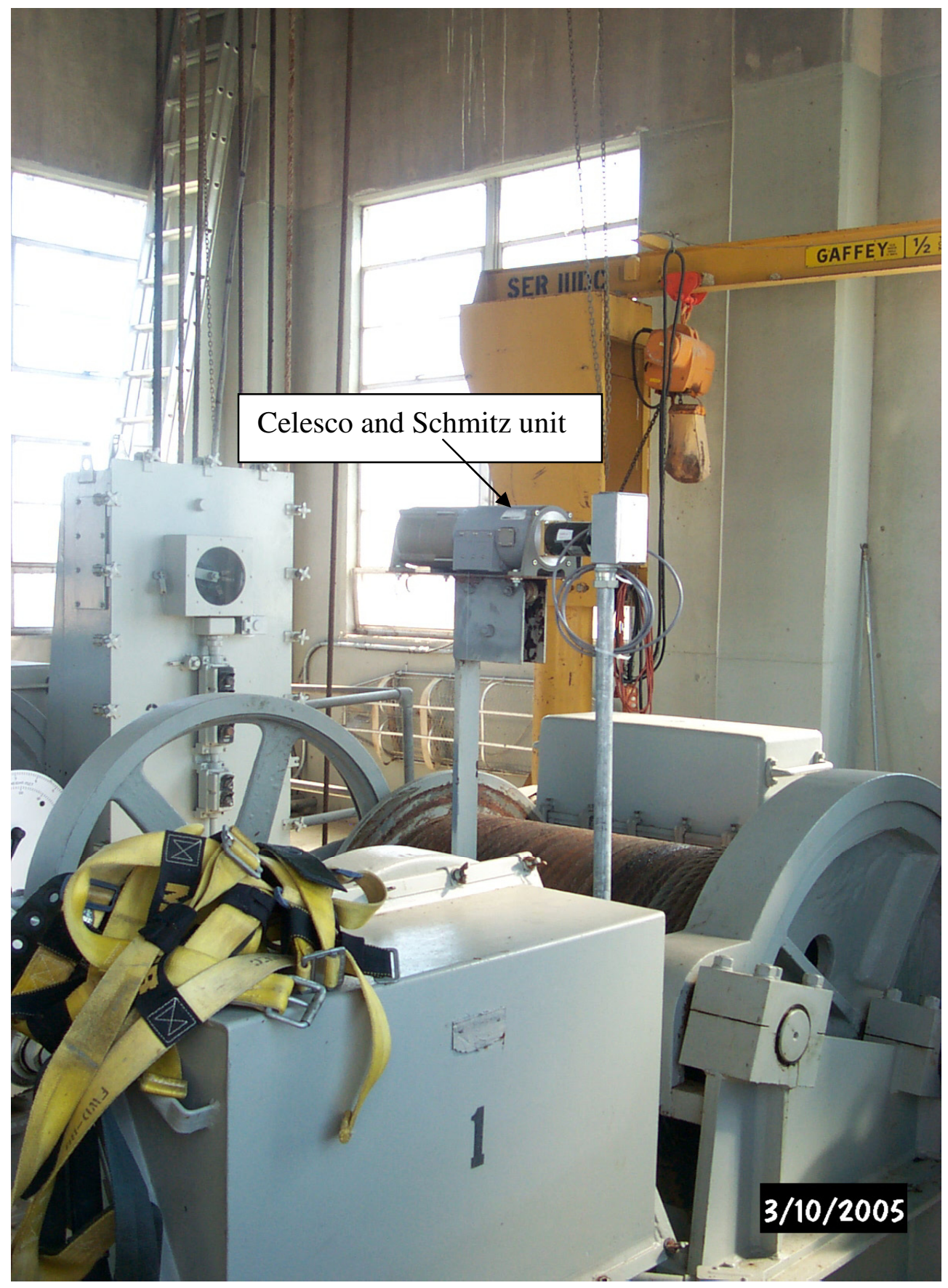

Figure 15. Gate-sensing equipment at Benbrook Lake. 


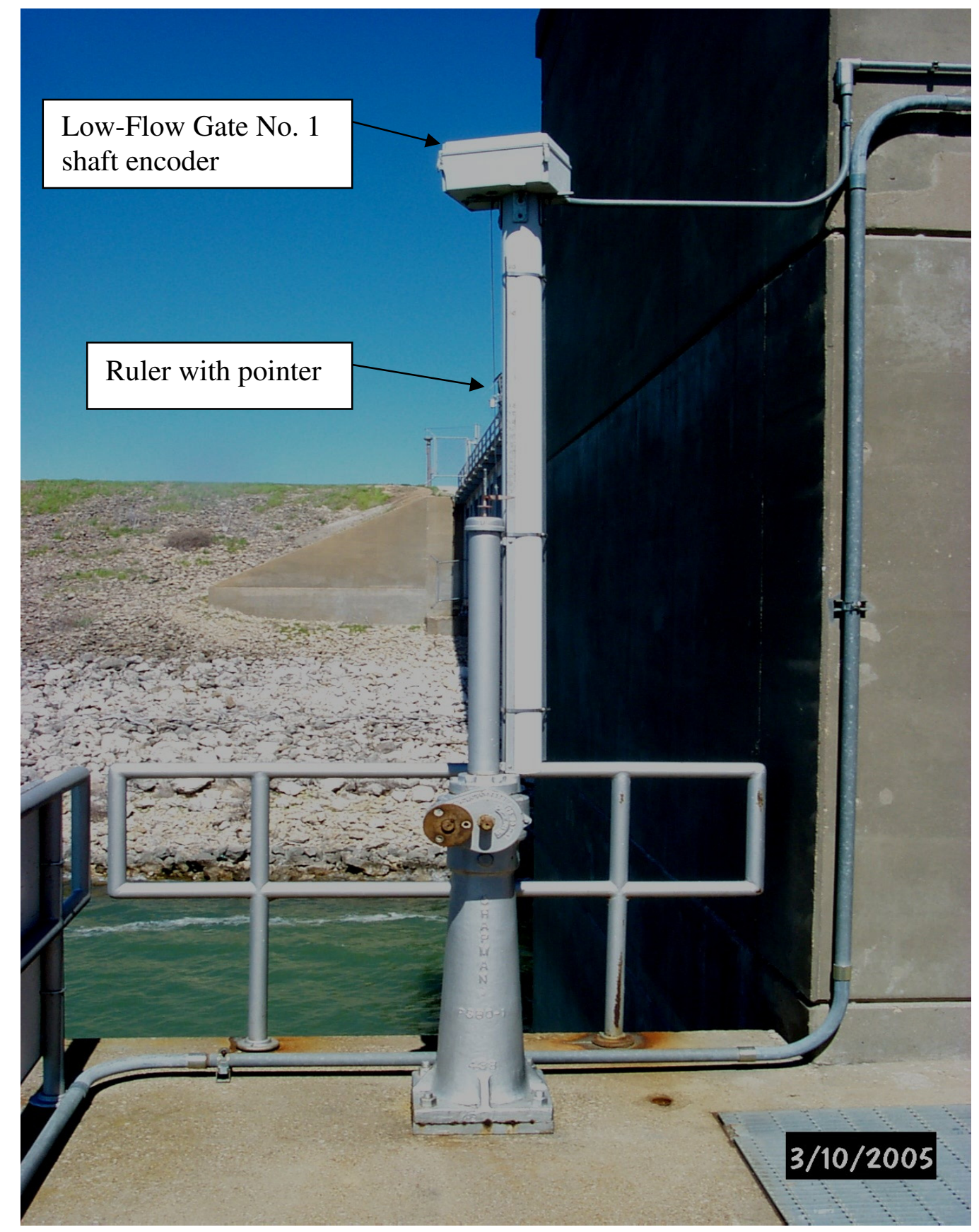

Figure 16. Low-Flow Gate No. 1 equipment at Benbrook Lake. 


\section{Benbrook Lake Sutron 8210 Setup File (BNBT2.SET)}

; 8210/8200 ASCII setup file, can be converted back to a .SET file with WSETMGR.EXE

;

; MAIN SETUP

;

Setup_Version=V6X

Unit_ID=BNBT2

Measurement_Interval=00:15:00

Sampling_Interval=00:00:00

Measurement_Time $=00: 00: 00$

Sampling_Time $=00: 00: 00$

Switched_Power_Time $=00: 00: 00$

Samples_to_Average $=0$

Measurements_per_Log=1

Switched_Power_Mode $=$ ON

Recording $=\mathrm{ON}$

Basic_Run_Interval=00:00:05

Basic_Run_Time $=00: 00: 00$

Password=

Number_Resets $=3$

Log_Size $=124928$

Rom_Checksum=57134

; EEROM SETUP

Serial_Port_Mode=USER

User_Baud_Rate $=9600$

Radio_Baud_Rate $=0$

Com_Baud_Rate $=0$

Transfer_Baud_Rate $=9600$

SDI_Baud_Rate $=1200$

Enter_Key_Reqd=ON

Log_Dump_Mode=ALL-BIN

User_Time_Limit $=600$

Power_Delay $=1$

Analog_Delay $=5$

Pressure_Delay $=5$

Auto_Startup_Keys=SS

Time_Format=NORMAL

Date_Format=MDY

Term_Xmit_Delay $=0$

Basic_Size $=1$

Amp_Gain=1.0

;

; PROTOCOL SETUP

Master_Name=

Carrier_Delay $=7$

Com_Port_Mode=

Reply_Delay $=0$

Ack_Delay $=100$ 


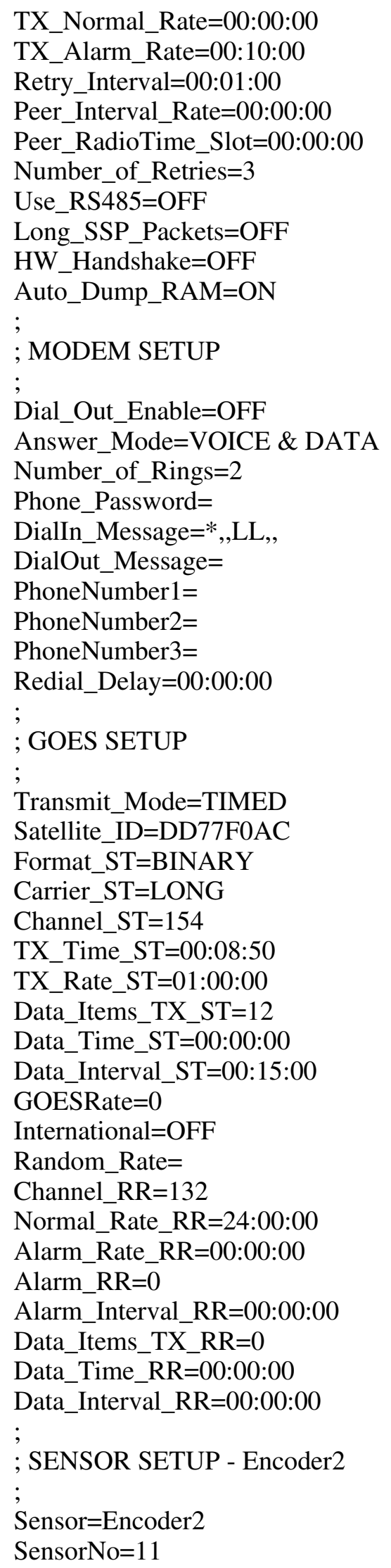




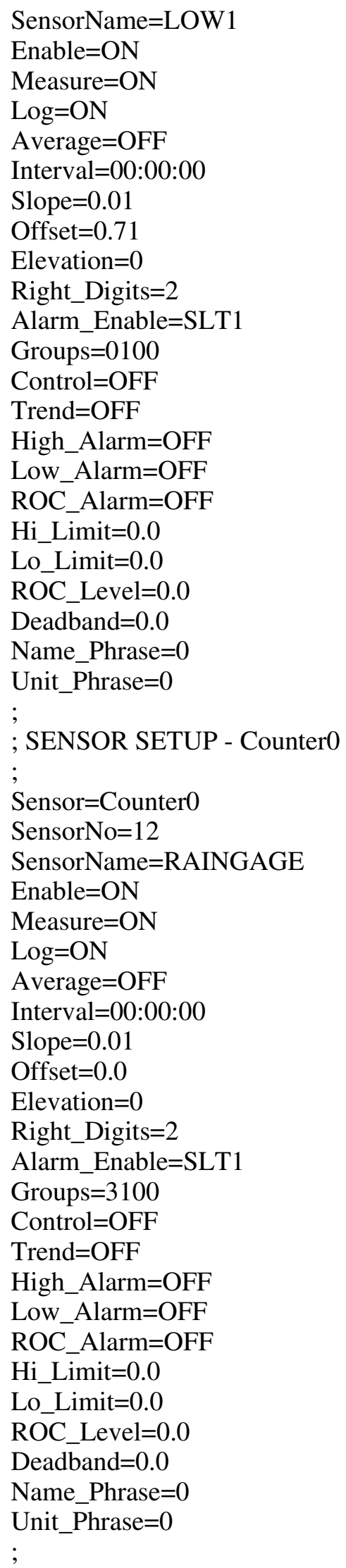




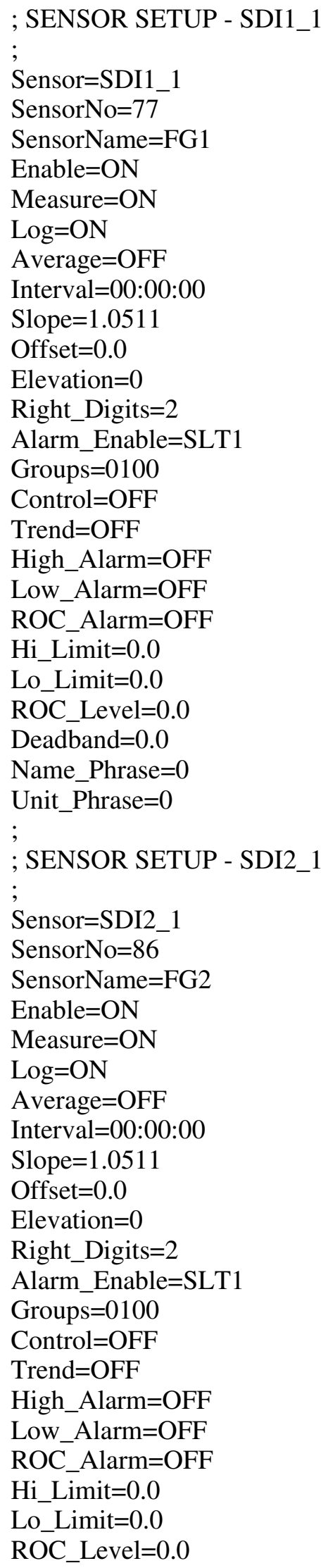




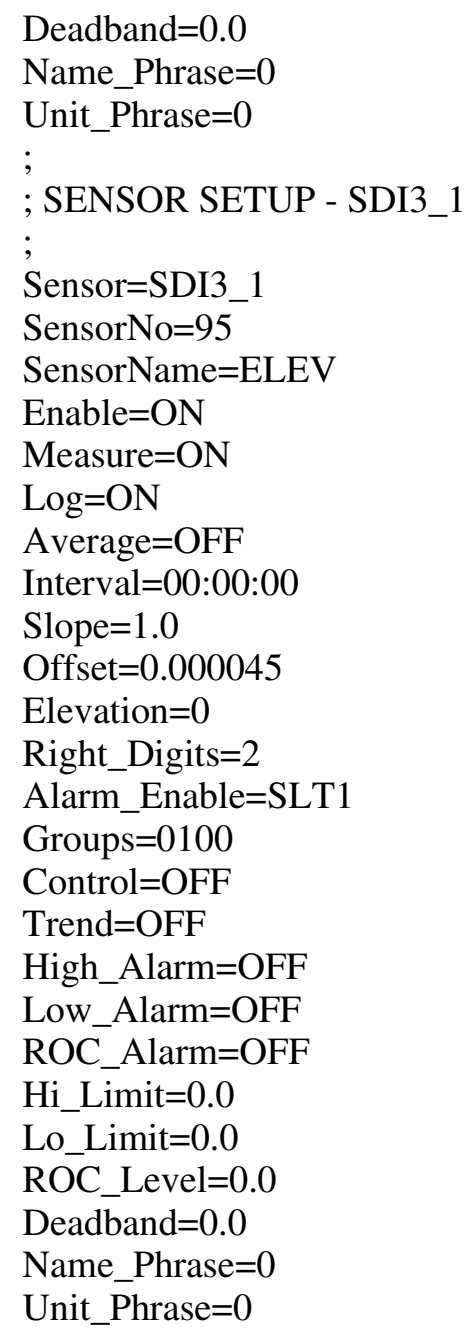

Benbrook Lake Sutron 8210 Basic Program (BNBT2.BAS)

1 'Tiny Basic program for the VORNE GY2200 display using RS-232.

10 Open "term:" NOWAIT

20 Control 1,2

'Enable RS-232 port.

30 Control 11,9600

'Set baud rate.

40 Print $27 \$ ; 7 \$ ; 48 ; 48 \$ \quad$ 'Set Scrolling speed.

$42 \mathrm{~A}=$ measure(FG1) : $\mathrm{B}=$ measure(FG2)

50 ?;a!2!2;b!2!2;27\$;70\$;

60 Control 2

70 Close

'Disable RS-232 port.

90 STOP

'Close port. 


\section{Canyon Lake Near New Braunfels, Tex.}

\section{Location}

Lat 29 52'07", long 98 11'55", Comal County, in intake structure of Canyon Dam on Guadalupe River, 12 mi northwest of New Braunfels, and 303.0 mi upstream from mouth.

\section{Road Log}

From USGS Texas WSC-Fort Worth, follow I-35 south to New Braunfels. Exit onto SH 306 (Canyon Lake exit) and travel north about 16 mi to South Access Rd. Turn left onto South Access Rd. and travel 0.6 mi to COE Rd. Turn right onto COE Rd. and drive to the end of the road. The USACE office is located near the overlook area. The intake structure is down the road along the top of the dam.

\section{Access}

Before visiting the site, call the Canyon Lake Dam USACE office at 830-964-3341. USACE staff will escort USGS staff and open the gate to the road along the top of the dam and the gate to the intake structure. The intake structure also is protected by an alarm.

\section{Equipment Description}

Refer to table 4, "Canyon Lake equipment inventory," for a complete list of equipment and to figures 17-22 for equipment wiring diagrams and photographs of equipment. Two main floodgates and two emergency gates are raised and lowered by hydraulic pistons. Floodgates No. 1 and No. 2 are labeled Service Gates 1 and 2; likewise the emergency gates are labeled Emergency Gates 1 and 2. Floodgates No. 1 and No. 2 will be used in this description to be consistent with naming conventions at other dams. All of the gate-sensing equipment is on the lower level of the intake structure, about 150 $\mathrm{ft}$ below the upper level, and accessible by a small elevator. Floodgate No. 1 is on the right side of the intake structure (facing upstream) and Floodgate No. 2 is on the left. Similarly, Emergency Gates No. 1 and No. 2 are located on the right and left side (facing upstream), respectively, of the intake structure.

The positions of the two floodgates and the emergency gates are displayed on digital displays manufactured by Precision Digital. Display labels are Gate 1 Service, Gate 2 Service, Gate 1 Emergency, and Gate 2 Emergency. The positions of the two floodgates (not the emergency gates) also are recorded by a Sutron 8210 datalogger.

Whessoe Varec 2500B automatic tank level gages indicate the position of both floodgates. Position is relayed to the Sutron 8210 datalogger with Whessoe Varec 8200 series liquid level transmitters. A steel tape runs from the top of each floodgate to the 2500B tank level gage where it wraps around a storage drum connected to a Neg'ator constant-force spring motor. The Neg'ator spring motor consists of a prestressed stainless-steel tape that is formed into a coil and stored on a small storage drum. The free end of the coil is wrapped backwards onto a larger output drum, then fastened to the drum. When the steel tape connected to the top of the gate winds up in the 2500B gage as 
the gate is raised, the tape of the Neg'ator spring motor will wind up onto the small storage drum. Conversely, when the steel tape connected to the top of the gate unwinds as the gate is lowered, the tape of the Neg'ator spring motor will unwind from the small storage drum and wind up on the output drum. In both instances the Neg'ator spring motor functions to provide a constant amount of force (torque) on the steel tape attached to the gate regardless of the amount of deflection. The movement of the small storage drum rotates a shaft inside the 8200 position transmitter. The shaft is coupled to a worm gear, which in turn drives the shaft of a potentiometer. Rotation of the shaft causes a change in the output current of the transmitter. The variations in current output are carried to the Sutron 8210 datalogger by two wires. At the datalogger, the current is passed through a resistor so a voltage can be measured. The output current of the transmitters varies from 4 to $20 \mathrm{~mA}$.

The Precision Digital display is different from Vorne displays at other dams (such as Benbrook, Wright Patman, Lake O' the Pines, and Jim Chapman) because the Vorne units only display the value that the datalogger measures and records. However, the Precision units are microprocessor-based digital process meters that display signals from inputs ranging from 4 to $20 \mathrm{~mA}$. Therefore, it is possible for the Sutron 8210 to measure and record a value different from the Precision units because each requires calibration. Refer to calibration procedures for instructions on how to calibrate the units.

Gate-sensing equipment that serves as a reference for the two floodgates is available at Canyon Dam, located on the lower level of the intake structure. The steel tape from the Whessoe Varec gages is attached to a rod that comes out of the top of the hydraulic cylinders. A pointer attached to the rod indicates gate position on a ruler.

The Sutron 8210 datalogger is powered by a 12-VDC battery, which is charged by an automatic sealed lead-acid battery charger connected to a $120-\mathrm{VAC}$ wall outlet. The position transmitters on the two floodgates are powered by 24 VDC from the Precision Digital displays. The Precision units have an input voltage of $120 \mathrm{VAC}$ and an output voltage to the transmitters of 24 VDC. The wires from the floodgates and the digital displays pass through a DC signal isolator before going to the datalogger. The signal isolator electrically insulates the analog DC output from the position transmitters for 4 to $20 \mathrm{~mA}$ and limits the voltage from the digital display to the Sutron 8210 to prevent damage to the equipment.

The setup file (CANYONLK.SET) for the datalogger is stored on the RAM card that is kept inside the Sutron equipment box. A hard copy of the setup file is also kept in the station folder.

The positions of Floodgates No. 1 and No. 2 are transmitted by satellite and posted on the USACE Web site (http://www.swf-wc.usace.army.mil) under Daily Reports/Gate Sensor Report. The USACE reports hourly data; however, the Sutron datalogger measures and records the gate position for the two gates every 15 minutes.

Floodgates No. 1 and No. 2 are FG1 and FG2, respectively, in the Sutron setup file.

\section{Operation and Maintenance}

Operation and maintenance information for the equipment at Canyon Dam includes descriptions of different procedures required to maintain equipment such as routine inspections, recalibration of Floodgates No. 1 and No. 2, recalibration of the Precision Digital displays, and annual inspections. The purpose of a site visit and the 
actions taken should be documented in the logbook kept near the datalogger. Include the date, time, actions, and personnel conducting the site visit in the logbook. This section lists some of the potential problems that might occur with the equipment in service and possible solutions to the problems. Refer to the Operations Manuals for the individual pieces of equipment when further detail is required. The information included here is basic operations and maintenance information.

For each visit to the site, personnel should carry all of the necessary tools required to service the equipment. The tools required to perform all of the tasks listed include the following:

- Screwdrivers, flat and Phillips head

- Crescent wrench, 10-in.

- Stepladder, 10-ft

- Electrical tape

- Digital multimeter

- Pliers

- Ruler

- Laptop computer capable of connecting (with RS-232 port and 9-pin cable) to Sutron 8210

- Sutron 8210 Operations Manual

- Whessoe Varec 2500 Installation and Operations Manual

- Whessoe Varec 8200 Installation and Operations Manual

- Precision Digital Model PD690 Instruction Manual

- Battery load tester

- Spare battery

- Flashlight

- Silicone sealant

\section{Procedures during a routine inspection}

- Check the enclosure to the Sutron 8210 datalogger for damage and moisture. If moisture is entering the enclosure, seal any openings with silicone.

- Scroll through the VIEW DATA/LIVE READINGS menu and check that the datalogger is making measurements.

- Check the antenna and make sure connections are secure and waterproofed. Replace electrical tape around connections if old and brittle.

- $\quad$ Check the battery voltage under the LIVE READINGS menu on the Sutron 8210.

- If voltage is low (less than $11.5 \mathrm{~V}$ ), test the battery with a load tester and make sure the voltage remains above the recommended voltage specific to the load tester being used. Replace battery as needed.

- Remove drain plug on bottom of position sensor and allow water to drain out.

- Verify that the Whessoe Varec position sensors and the Sutron 8210 datalogger measure the same values (within $0.01 \mathrm{ft}$ ) for the positions of Floodgates No. 1 and No. 2. Next compare the values from the position sensors and the datalogger to the pointer reading. If the position sensors and datalogger values are within $0.01 \mathrm{ft}$ of each other and within $0.13 \mathrm{ft}$ of the pointer reading, no action is required. If the position sensors and the datalogger values differ by more than $0.01 \mathrm{ft}$ or by more than $0.13 \mathrm{ft}$ of the pointer reading, refer to the recalibration procedures. The 
increments on the ruler are $0.25 \mathrm{ft}$; therefore, the ruler and the pointer can be read accurately to at least one-half of the increment, or $0.13 \mathrm{ft}$.

- Compare the measurements on the Precision Digital displays to those in the Sutron datalogger. If the measurements are the same (within $0.01 \mathrm{ft}$ ), no action is required. If they are different, consider recalibrating the digital displays. Refer to the recalibration procedures.

- Before leaving the site, make sure the Sutron 8210 is reading ON \& TX under RECORDING.

\section{Procedures to recalibrate Floodgates No. 1 and No. 2}

- Completely lower the gate requiring calibration and set the Whessoe Varec position sensor to measure 0.00. To do this, refer to the Whessoe Varec 2500 Installation and Operations Manual (p. 33-34). If the position sensor measures 0.00 when the gate is lowered completely, only the Sutron requires calibration.

- Caution: Before executing this procedure, make sure the emergency gates are closed. To calibrate the Sutron after setting the Whessoe Varec unit to measure 0.00 , first record the current slope and offset for the gate being calibrated. Next, set the slope and the offset to 1.00 and 0.00 , respectively. With the gate still completely closed, scroll down to SYSTEM SETUP. Press the right arrow once and scroll down to CONFIG SENSORS. Press the right arrow once and scroll down to the gate that is being calibrated. With the correct gate selected, press the right arrow once and scroll down to VALUE. Enter the correct value, which would be 0.00 , then press the SET button. Next, open the gate as much as possible so that the instrument will be calibrated over the entire range of gate positions. With the gate open as much as possible, enter the value from the Whessoe Varec dial into the VALUE field and press the SET button. The datalogger will calculate the slope and the offset from the two known positions entered.

- Verify that the Whessoe Varec position sensor and the Sutron 8210 datalogger are now measuring the same position with the gate open as much as possible. Also verify that the measurements are within $0.13 \mathrm{ft}$ of the pointer reading. After verification, close the gate completely and check that both measure 0.00 with the gate completely closed. If so, the calibration is complete; if not, perform the calibration again.

- Whenever a change is made to the setup file in the datalogger, download the new file to the RAM card kept at the site. To do this, insert the RAM card into the socket and turn on the 8210. Scroll down to the DUMP DATA menu. Press the right arrow once, then press the down arrow until WRITE CARD SETUP is displayed. Press the SET button and wait for the file to be transferred from the datalogger to the RAM card. To transfer the file from the RAM card to the datalogger, scroll down to the DUMP DATA menu. Press the right arrow once, then press the down arrow until READ CARD SETUP is displayed. Press the right arrow to access the setup file. Transfer the selected file to the datalogger by pressing the SET button.

- Record changes to the slope or the offset in the logbook. 


\section{Procedures to recalibrate Precision Digital displays}

- Completely lower the gate requiring calibration, then remove the black wire going into the display $\mathrm{S}+$ port. Be careful because the black and white wires in the two $\mathrm{L}$ ports of the digital display are hot (120 VAC).

- Put one terminal from a multimeter into the $S+$ port and connect the other end to the black wire that was removed so the current can be measured.

- Record the current, in milliamps, with the gate closed.

- Next open the gate as much as possible so that the instrument will be calibrated over the entire range of gate positions. With the gate open as much as possible, again measure the current passing through the wires and record the gate position (according to the Whessoe Varec position sensor) for the given current. Caution: Before executing this procedure, make sure the emergency gates are closed.

- Refer to the Precision Digital Model PD360 Instruction Manual (p. 21-22) for instructions to input the values from the previous steps. Before inputting the values, the manual asks the user to select a calibration method. This method uses an internal signal source; therefore, the I-CAL method should be selected.

- IMPORTANT NOTE. The Precision Digital displays do not have to be calibrated for the Sutron 8210 to record the correct values. The two are independent of one another. The only reason to calibrate the displays is for USACE staff to be able to read the positions of the gates easily.

- The values measured by the Sutron 8210 and the digital displays might be difficult to match within $0.01 \mathrm{ft}$.

\section{Procedures during an annual inspection}

- During an inspection the emergency gates are lowered, and the floodgates are raised all the way up and cleaned and inspected. As the gates are lowered after being serviced, check that the position sensors and datalogger measure the same values. If not, follow the instructions to recalibrate the instruments.

- After the inspection, follow all of the procedures during a routine inspection. 
Table 4. Canyon Lake equipment inventory.

[See table of contents for abbreviated units; --, not available or not applicable]

\begin{tabular}{|c|c|c|c|c|}
\hline Item no. & Item description & Manufacturer & Model no. & Remarks \\
\hline 1. & $\begin{array}{l}\text { Floodgate No. } 1 \text { position } \\
\text { sensor }\end{array}$ & Whessoe Varec & 2500B & $\begin{array}{l}\text { Gate is FG1 in Sutron setup and equipment is labeled } \\
\text { Service Gate } 1\end{array}$ \\
\hline 2. & $\begin{array}{l}\text { Floodgate No. } 1 \text { position } \\
\text { transmitter }\end{array}$ & Whessoe Varec & 82000100 & $\begin{array}{l}\text { Analog transmitter with current output of } 4 \text { to } 20 \mathrm{~mA} \text { and input } \\
\text { of } 15 \text { to } 48 \mathrm{VDC}\end{array}$ \\
\hline 3. & $\begin{array}{l}\text { Wire for position transmitter } \\
\text { No. } 1\end{array}$ & -- & -- & $350 \mathrm{ft}$ of $16 \mathrm{AWG} / 2$ wires \\
\hline 4. & $\begin{array}{l}\text { Floodgate No. } 2 \text { position } \\
\text { sensor }\end{array}$ & Whessoe Varec & $2500 \mathrm{~B}$ & $\begin{array}{l}\text { Gate is FG2 in Sutron setup and equipment is labeled } \\
\text { Service Gate } 2\end{array}$ \\
\hline 5. & $\begin{array}{l}\text { Floodgate No. } 2 \text { position } \\
\text { transmitter }\end{array}$ & Whessoe Varec & 82000100 & $\begin{array}{l}\text { Analog transmitter with current output of } 4 \text { to } 20 \mathrm{~mA} \text { and input } \\
\text { of } 15 \text { to } 48 \mathrm{VDC}\end{array}$ \\
\hline 6. & $\begin{array}{l}\text { Wire for position transmitter } \\
\text { No. } 2\end{array}$ & -- & -- & $350 \mathrm{ft}$ of $16 \mathrm{AWG} / 2$ wires \\
\hline 7. & Stage shaft encoder & Handar & $436 \mathrm{~A}$ & ELEVATION in Sutron setup and SDI12 address 0 \\
\hline 8. & Rain gage & $\begin{array}{l}\text { Texas } \\
\text { Electronics, Inc. }\end{array}$ & TR-525I & -- \\
\hline 9. & Datalogger & Sutron & 8210 & -- \\
\hline 10. & Digital display & Precision Digital & PD690-3-N & $\begin{array}{l}\text { Displays the position of both floodgates and both emergency } \\
\text { gates }\end{array}$ \\
\hline 11. & DC signal isolator & SINEAX & TI 816-5110 & $\begin{array}{l}\text { Electrically insulates analog DC output from position } \\
\text { transmitters to } 4 \text { to } 20 \mathrm{~mA} \text { and limits voltage from digital } \\
\text { display to Sutron } 8210\end{array}$ \\
\hline 12. & Battery & Power Sonic & PS1-2550U & $12-\mathrm{V}, 55.0-\mathrm{A}-\mathrm{h}$ battery for Sutron 8210 \\
\hline 13. & Battery charger & Power Sonic & PSC-12500A & $12-\mathrm{V}, 500-\mathrm{mA}$ \\
\hline 14. & Voltage regulator & -- & -- & $\begin{array}{l}\text { On side of regulator, label reads USGS regulator, Serial No. } \\
85040093\end{array}$ \\
\hline 15. & Antenna & -- & YAGI & 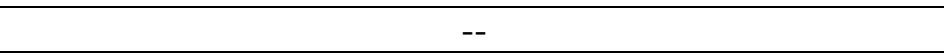 \\
\hline 16. & Antenna cable & $\begin{array}{l}\text { Pasternack } \\
\text { Enterprises }\end{array}$ & RG58 C/U & 20-ft cable from Sutron 8210 to antenna \\
\hline 17. & Antenna polyphaser & PolyPhaser & IS-50NX-C1 & -- \\
\hline
\end{tabular}




\section{Job Hazard Analysis}

Required protective clothing, safety equipment, and supplies: Personal flotation device (PFD), reflective vest, gloves, steel-toed shoes, waders, cell phone, first aid kit, fire extinguisher, rotating or strobe type emergency lights, drinking water.

\begin{tabular}{|c|c|c|}
\hline $\begin{array}{l}\text { Sequence of basic } \\
\text { job steps }\end{array}$ & $\begin{array}{l}\text { Potential } \\
\text { accident or hazard }\end{array}$ & Recommended safe job procedures \\
\hline $\begin{array}{l}\text { Upon job } \\
\text { assignment }\end{array}$ & $\begin{array}{l}\text { Water-related accident or } \\
\text { injury }\end{array}$ & $\begin{array}{l}\text { Employees working in and around water must receive } \\
\text { training specified in WRD Memo 2000.10, "Policy for } \\
\text { safety training associated with over-water activities. " }\end{array}$ \\
\hline $\begin{array}{l}\text { Loading and } \\
\text { unloading } \\
\text { equipment }\end{array}$ & $\begin{array}{l}\text { Pinched fingers, mashed } \\
\text { toes, or strained back }\end{array}$ & $\begin{array}{l}\text { Be aware of hand placement. Wear protective gloves and } \\
\text { steel-toed shoes. Use proper lifting techniques. Lift with } \\
\text { legs. Use extra caution lifting heavy sounding weights. }\end{array}$ \\
\hline $\begin{array}{l}\text { Driving to and } \\
\text { returning from work } \\
\text { site }\end{array}$ & $\begin{array}{l}\text { Traffic accidents, vehicle } \\
\text { flooding, or drowning }\end{array}$ & $\begin{array}{l}\text { Drivers of USGS vehicles must have Drivers Safety } \\
\text { Training (SM 445-2-H, chap. 16). Be alert to traffic in } \\
\text { area, obey all traffic laws, and reduce speed when weather } \\
\text { conditions are bad. Do not drive across flooded highways } \\
\text { unless water depth and bridge conditions are known to be } \\
\text { safe. }\end{array}$ \\
\hline Parking vehicle & $\begin{array}{l}\text { Personal and vehicle } \\
\text { safety when exiting } \\
\text { vehicle in traffic; bank } \\
\text { collapse or bridge failure }\end{array}$ & $\begin{array}{l}\text { Use rotating or strobe emergency lights, follow site } \\
\text { traffic-control plan, wear DOT Type III reflective vest } \\
\text { when working in or near roadway. Park away from stream } \\
\text { at a safe distance from banks. }\end{array}$ \\
\hline $\begin{array}{l}\text { Set up traffic- } \\
\text { control equipment }\end{array}$ & $\begin{array}{l}\text { Personal and public } \\
\text { safety }\end{array}$ & $\begin{array}{l}\text { Employees working in or near roadways must have Work } \\
\text { Zone Traffic-Control Safety Training. Remain alert to } \\
\text { traffic conditions. }\end{array}$ \\
\hline $\begin{array}{l}\text { Working at field } \\
\text { site }\end{array}$ & Drowning & $\begin{array}{l}\text { Employees are required to wear a PFD when working in, } \\
\text { on, or over any body of water. There are no exemptions } \\
\text { for employees in the Texas WSC. PFDs will be } \\
\text { international orange in color and equipped with reflective } \\
\text { tape in accordance with } 46 \text { CFR } 25.25-15 \text {. Self-inflating } \\
\text { PFDs are not to be worn by employees who have not had } \\
\text { In-Water Safety Training. }\end{array}$ \\
\hline $\begin{array}{l}\text { Working at field } \\
\text { site }\end{array}$ & Trips, slips, and falls & $\begin{array}{l}\text { Follow path clear of obstructions and with minimal slope; } \\
\text { avoid slippery surfaces. Walk cautiously on steep slopes } \\
\text { or paths with loose material. Use appropriate footwear for } \\
\text { the terrain and conditions. Follow the safest, not the } \\
\text { fastest path! }\end{array}$ \\
\hline $\begin{array}{l}\text { Working at field } \\
\text { site }\end{array}$ & $\begin{array}{l}\text { Dehydration, heat } \\
\text { exhaustion, heat stroke, } \\
\text { or sunburn }\end{array}$ & $\begin{array}{l}\text { Drink plenty of water or electrolyte drink. Wear } \\
\text { appropriate clothing. Take occasional breaks and watch } \\
\text { for symptoms of heat exhaustion. Use sun block. }\end{array}$ \\
\hline $\begin{array}{l}\text { Working at field } \\
\text { site }\end{array}$ & Hypothermia or frostbite & $\begin{array}{l}\text { Wear foul-weather gear during winter months. Keep } \\
\text { clothing dry. }\end{array}$ \\
\hline $\begin{array}{l}\text { Working at field } \\
\text { site }\end{array}$ & Snake bites & $\begin{array}{l}\text { Wear appropriate foot and leg protection. Watch path } \\
\text { ahead. Keep area around gage clear of brush. If bitten, } \\
\text { seek immediate medical help. }\end{array}$ \\
\hline
\end{tabular}




\begin{tabular}{|l|l|l|}
\hline $\begin{array}{l}\text { Working at field } \\
\text { site }\end{array}$ & Poisonous plants & $\begin{array}{l}\text { Know how to identify poisonous plants. Wear protective } \\
\text { clothing. Wash and flush exposed areas immediately with } \\
\text { cold water. Wash with degreasing type soap and flush } \\
\text { from skin. Seek medical attention for severe reactions. }\end{array}$ \\
\hline Entering gage house & $\begin{array}{l}\text { Infectious disease or } \\
\text { airborne pollutants; risk } \\
\text { of hantavirus exposure. }\end{array}$ & $\begin{array}{l}\text { Watch for bat or rodent nest and droppings. If nest or } \\
\text { droppings are present, do not disturb dust. Gage should be } \\
\text { periodically cleaned to minimize risk of exposure. See } \\
\text { WRD memo dated 10/28/97, "Preventing hantavirus } \\
\text { disease," and OP memo dated 01/94, "Instructions for } \\
\text { preventing hantavirus disease." }\end{array}$ \\
\hline Entering gage house & Insect or snake bite & $\begin{array}{l}\text { Inspect in and around shelter for harmful insects. Use } \\
\text { wasp or insect spray. Inspect in and around shelter for } \\
\text { snakes prior to entry. }\end{array}$ \\
\hline
\end{tabular}

\section{Site-Specific Job Hazards}

The items listed are safety issues specific to this site that deserve special emphasis.

- Descend in the elevator to the gate-sensing equipment with USACE staff and notify other staff at office when you expect to be done. Instruct staff remaining above that you will call them when you are out to prevent being stranded below for very long if elevator malfunctions. Gate-sensing equipment is about $150 \mathrm{ft}$ below the upper deck.

- Be careful descending spiral staircase from the floor where elevator stops to the floor below with the gate-sensing equipment. The ceiling is low and it is easy to bump your head. The difference between the two floors is about $25 \mathrm{ft}$.

- Be careful working in or around the digital displays. The digital displays are powered with $120 \mathrm{VAC}$. 
Figure 17. Canyon Lake Sutron 8210 wiring panel.
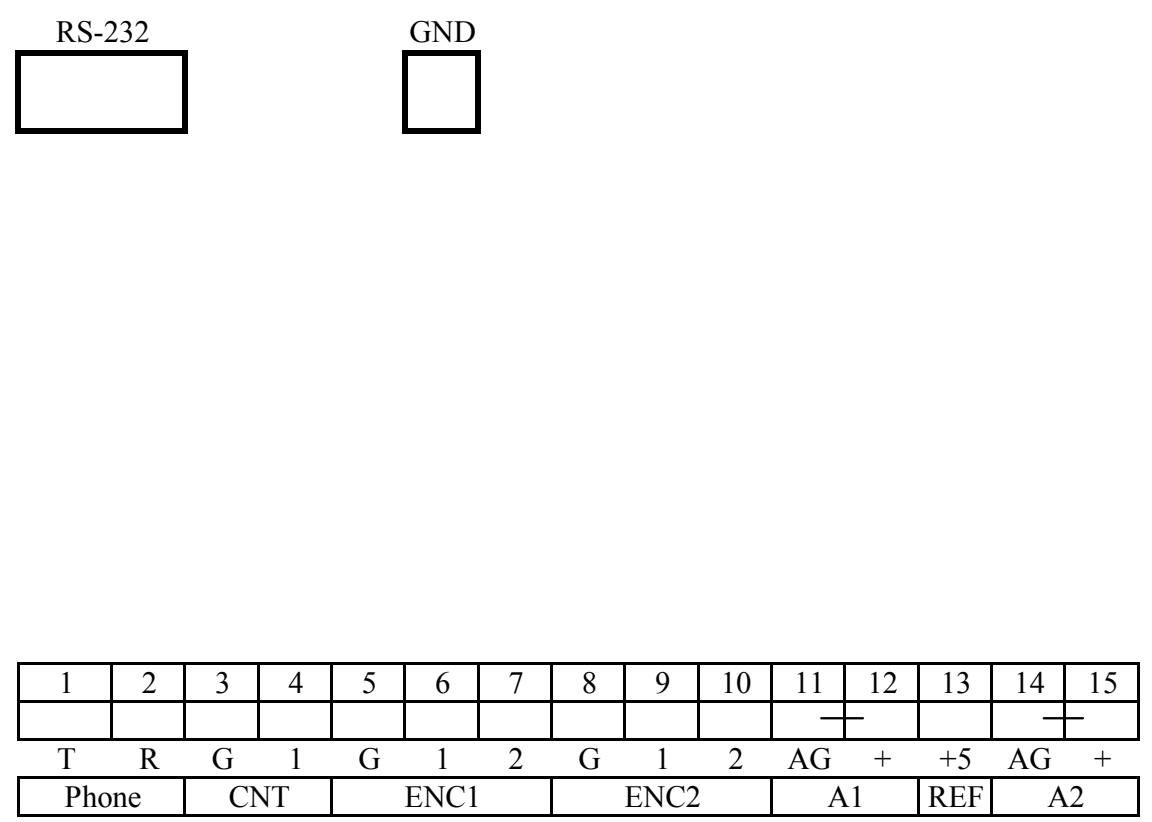

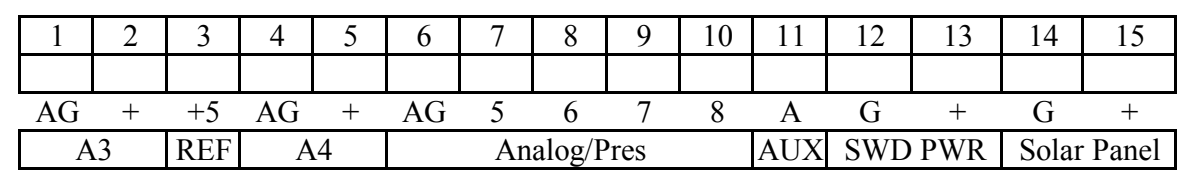

\begin{tabular}{|c|c|c|c|c|c|c|c|c|c|c|c|c|c|c|}
\hline \multicolumn{2}{|c|}{ Ext Batt } & \multicolumn{2}{|c|}{ RS485 } & \multicolumn{3}{|c|}{ SDI-12 } & \multicolumn{3}{|c|}{ SDI-12 } & \multicolumn{5}{|c|}{ Digital Output } \\
\hline G & + & $\bar{A}$ & $\bar{B}$ & $\bar{G}$ & + & $\mathrm{D}$ & $\bar{G}$ & + & $\mathrm{D}$ & 1 & 2 & 3 & 4 & 5 \\
\hline 1 & 2 & 3 & 4 & 5 & 6 & 7 & 8 & 9 & 10 & 11 & 12 & 13 & 14 & 15 \\
\hline
\end{tabular}

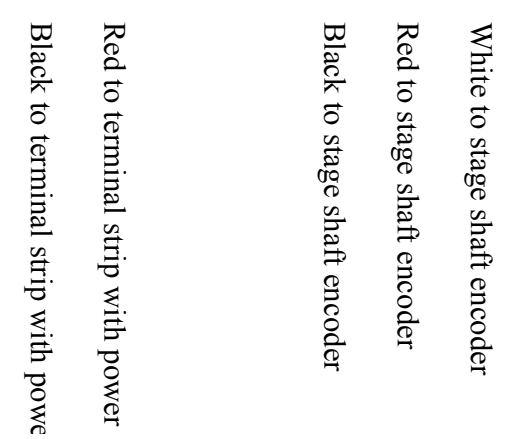

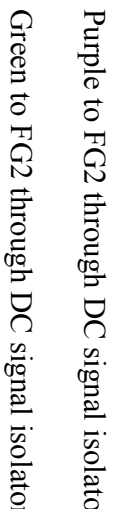

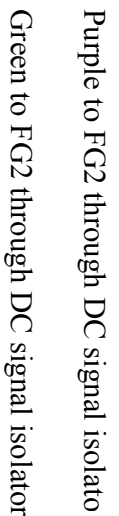

Note: FG1, Floodgate No. 1

FG2, Floodgate No. 2

$千$ denotes a resistor between the two ports of the Sutron. 
Figure 18. Canyon Lake equipment wiring diagram.
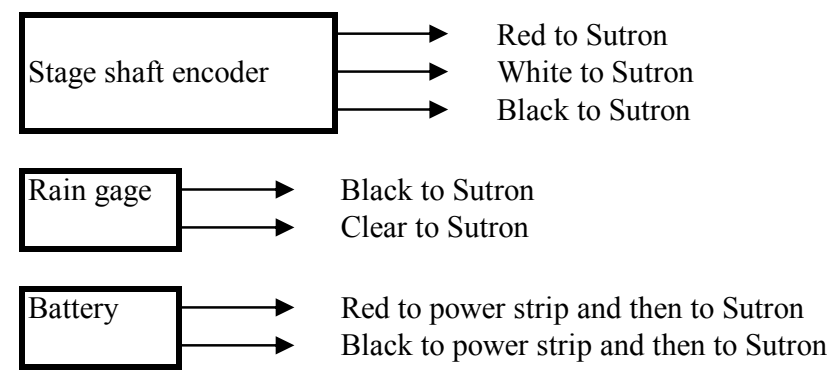

$\begin{array}{ll}\begin{array}{l}\text { Battery } \\ \text { charger }\end{array} & \text { Black to voltage regulator } \\ & \text { Red to voltage regulator }\end{array}$

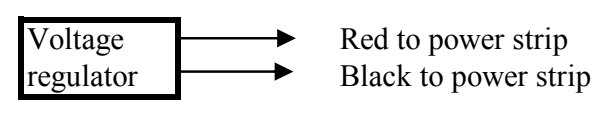

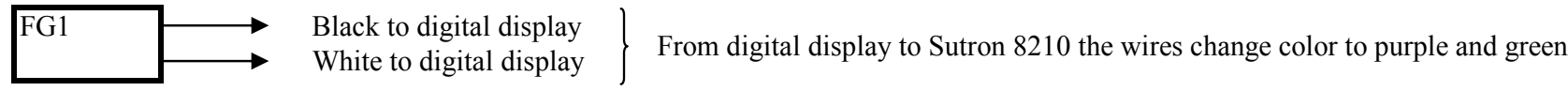

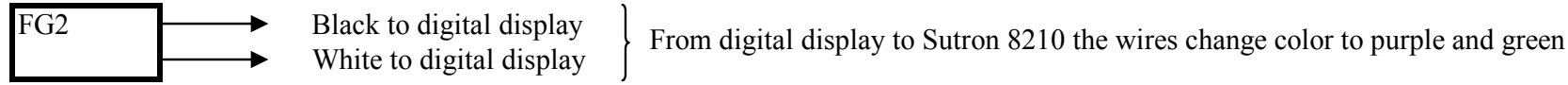

\begin{tabular}{c|c|l|}
\hline $\begin{array}{l}\text { Purple from Sutron } \\
\text { Green from Sutron }\end{array}$ & DC signal isolator & + \\
\hline
\end{tabular}

\begin{tabular}{|c|c|c|c|c|c|c|c|c|}
\hline \multicolumn{9}{|c|}{ Precision Digital display } \\
\hline $\mathrm{AK}$ & $\mathrm{H}$ & $\mathrm{CM}$ & $\mathrm{S}+$ & S- & P- & $\mathrm{P}+$ & $\mathrm{L}$ & $\mathrm{L}$ \\
\hline & & & 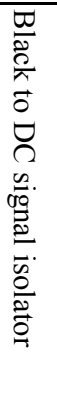 & & & 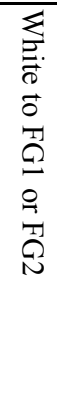 & 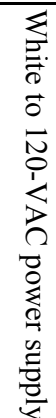 & 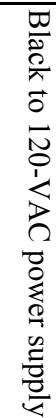 \\
\hline
\end{tabular}

Note: $\quad$ FG1, Floodgate No. 1.

FG2, Floodgate No. 2 . 


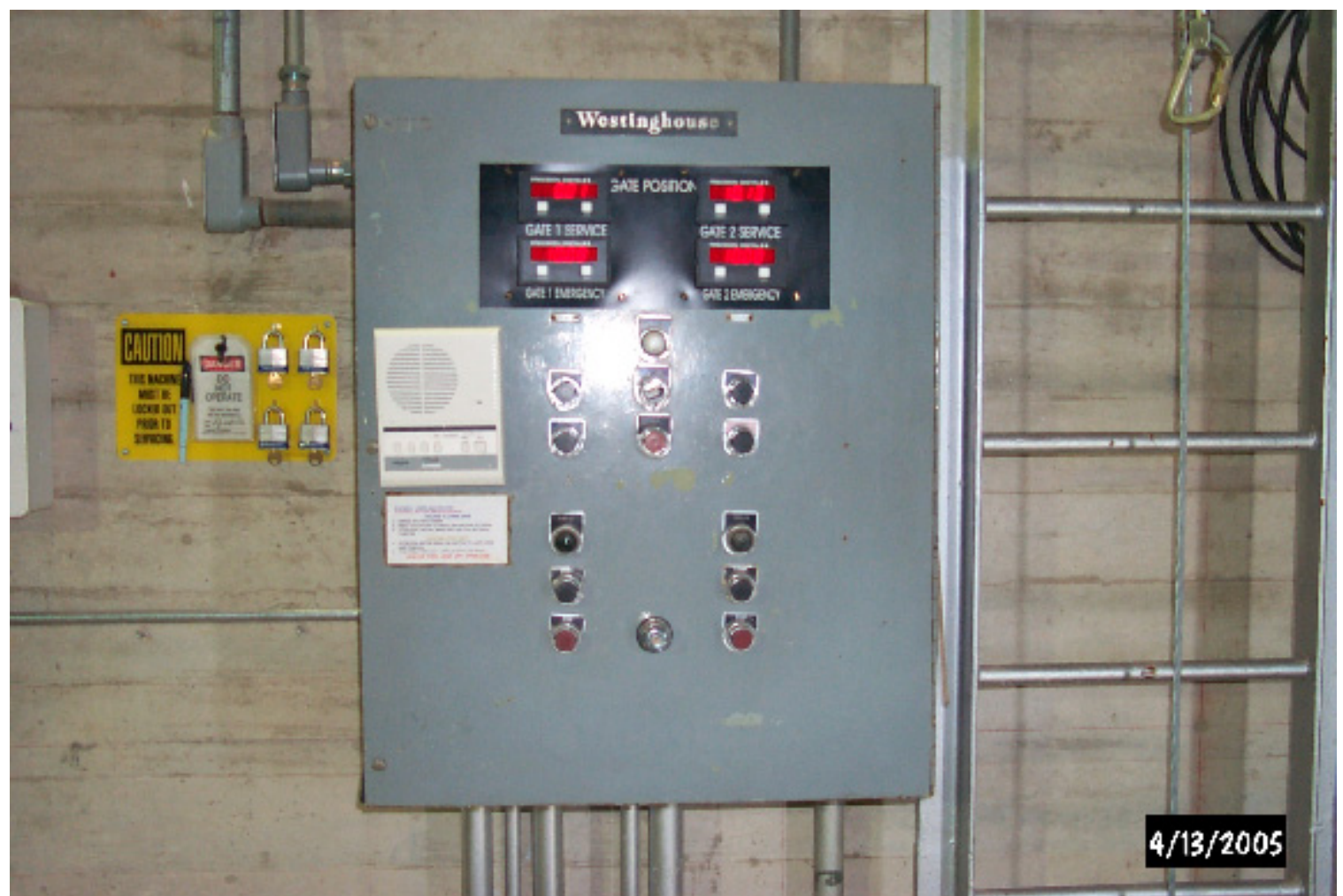

Figure 19. Precision Digital displays and control box at Canyon Lake.

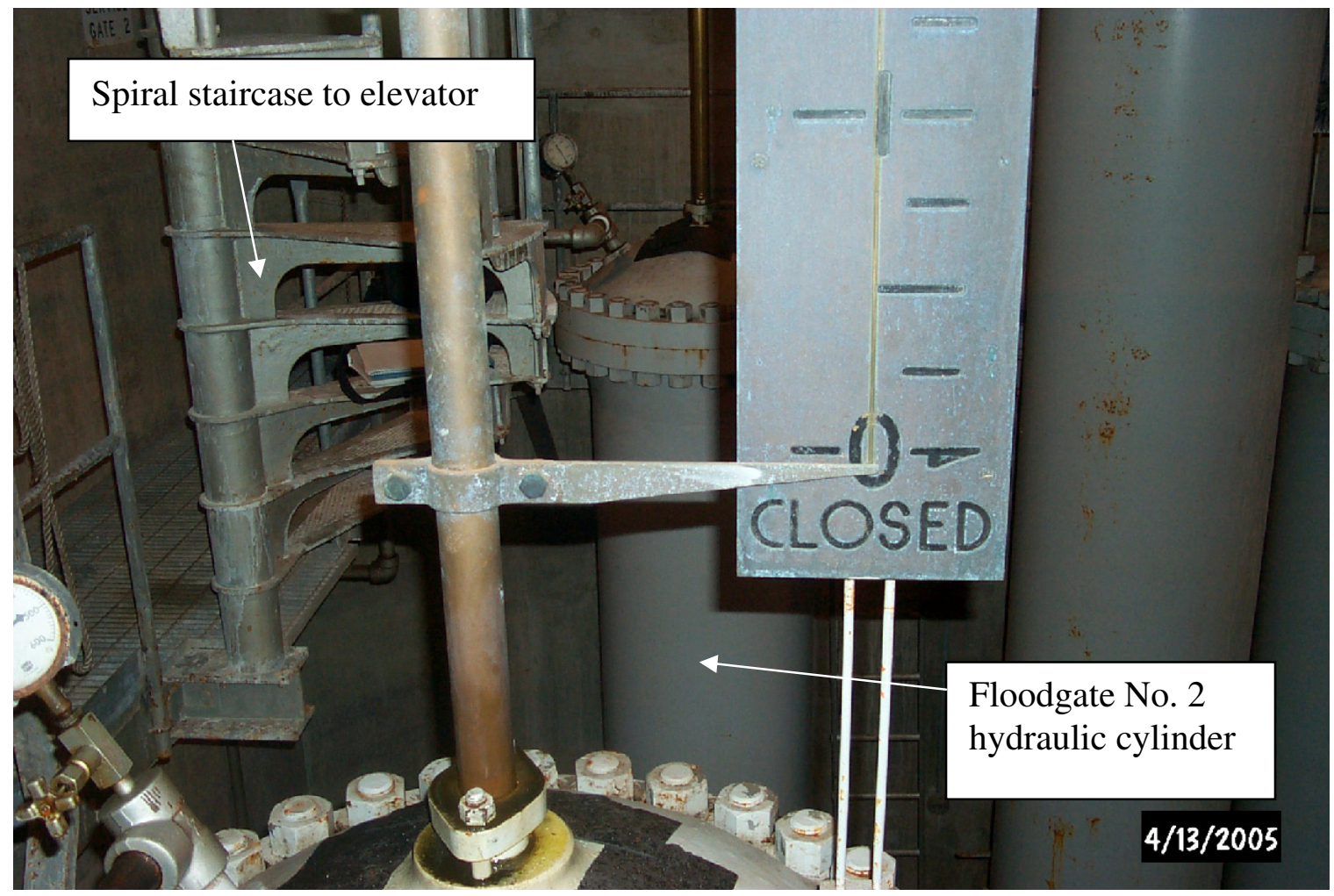

Figure 20. Floodgate No. 1 pointer and ruler at Canyon Lake. 


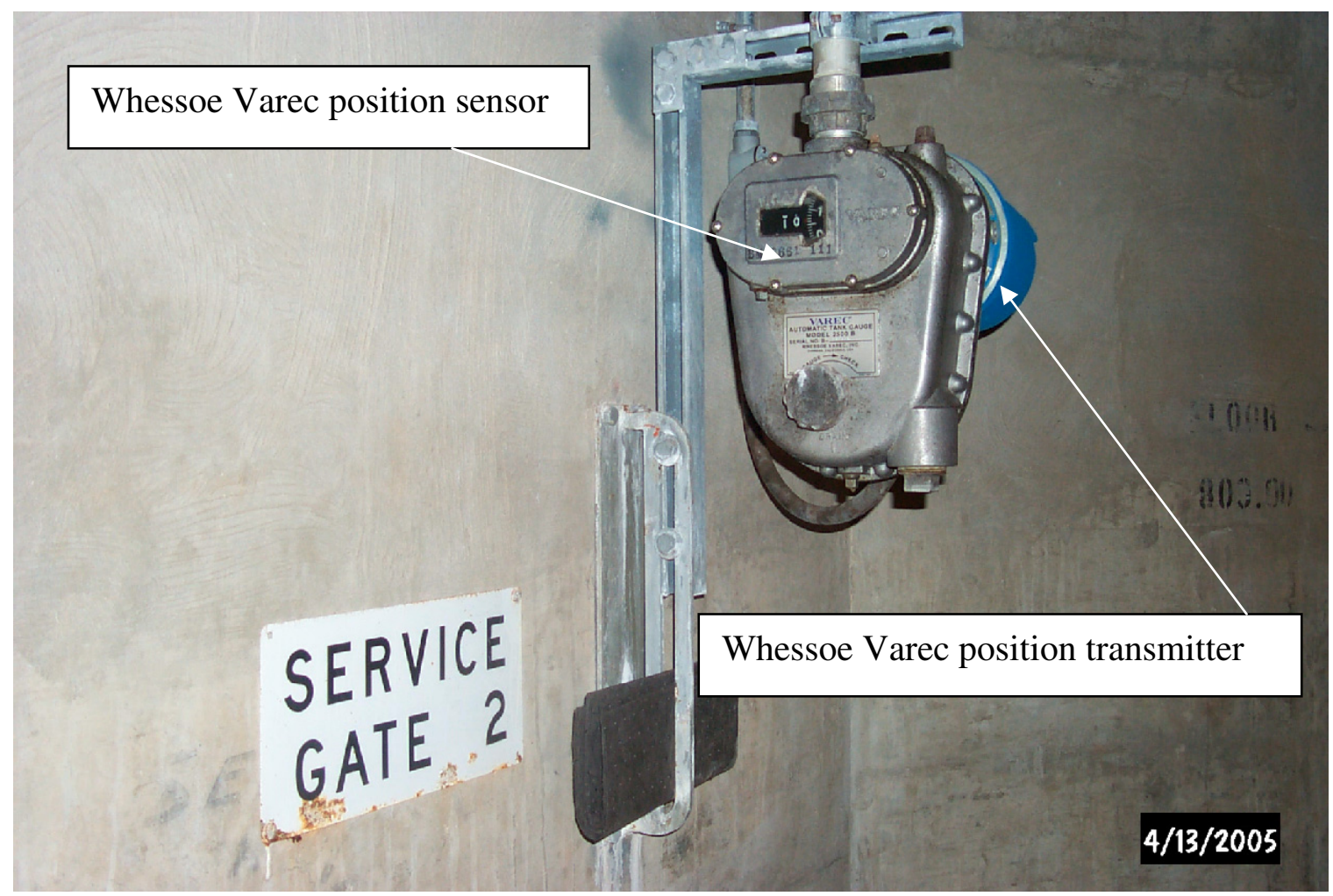

Figure 21. Floodgate No. 2 position sensor and transmitter at Canyon Lake. 


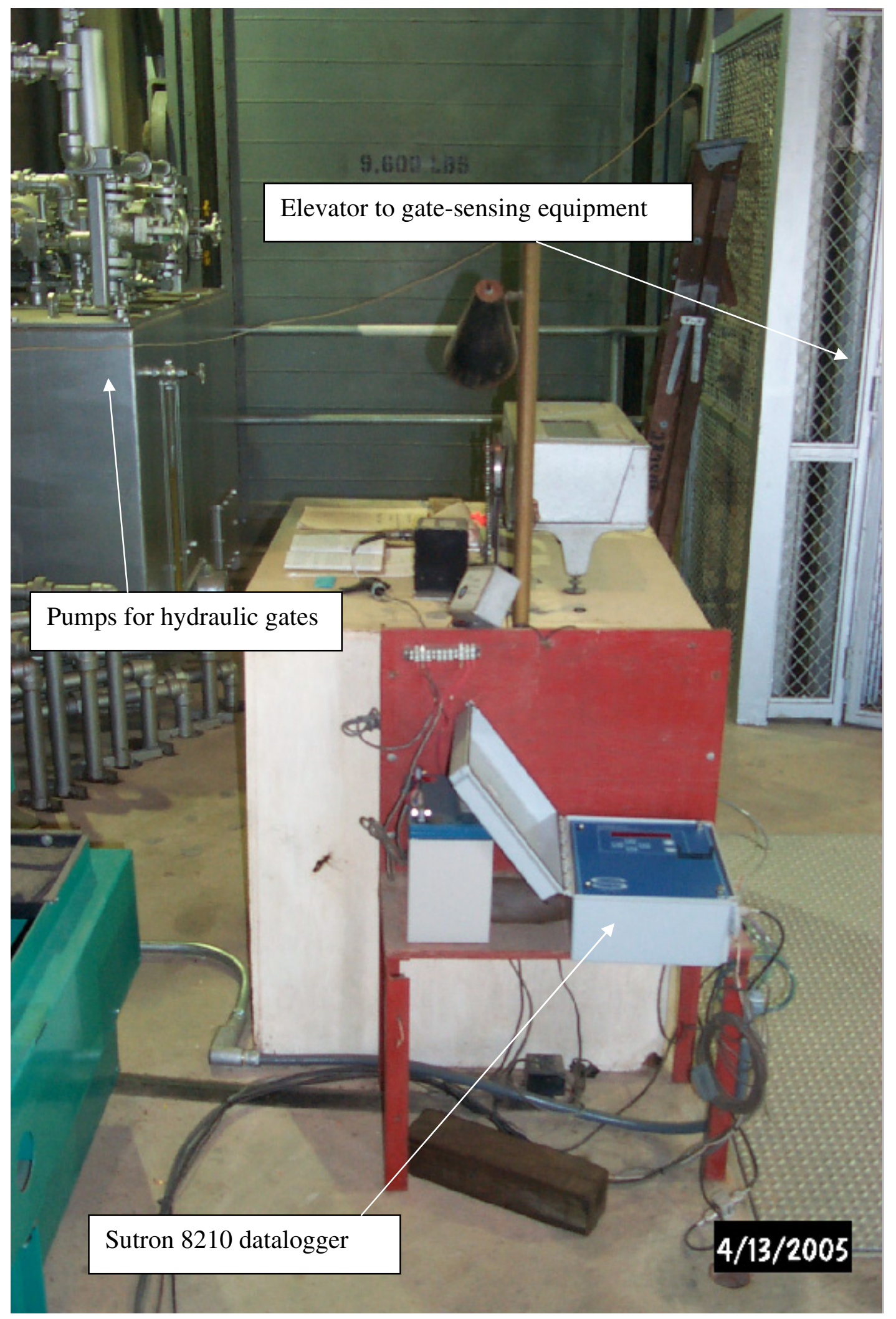

Figure 22. Sutron 8210 datalogger, elevator, and hydraulic pumps at Canyon Lake. 


\section{Canyon Lake Sutron 8210 Setup File (CANYONLK.SET)}

; 8210/8200 ASCII setup file, can be converted back to a .SET file with WSETMGR.EXE

;

; MAIN SETUP

;

Setup_Version $=$ V4X

Unit_ID=CANYONLK

Measurement_Interval=00:15:00

Sampling_Interval=00:00:00

Measurement_Time $=00: 00: 00$

Sampling_Time $=00: 00: 00$

Switched_Power_Time $=00: 00: 00$

Samples_to_Average $=0$

Measurements_per_Log $=1$

Switched_Power_Mode=OFF

Recording $=\mathrm{ON}$

Basic_Run_Interval=00:00:00

Basic_Run_Time $=00: 00: 00$

Password=

Number_Resets $=38$

Log_Size $=124928$

Rom_Checksum=10811

;

; EEROM SETUP

Serial_Port_Mode=USER

User_Baud_Rate $=9600$

Radio_Baud_Rate $=1200$

Com_Baud_Rate $=9600$

Transfer_Baud_Rate $=9600$

SDI_Baud_Rate $=1200$

Enter_Key_Reqd=ON

Log_Dump_Mode=ALL-BIN

User_Time_Limit=666

Power_Delay $=1$

Analog_Delay $=5$

Pressure_Delay $=5$

Auto_Startup_Keys=DDDDDDRRDDDD

Time_Format=NORMAL

Date_Format=MDY

Term_Xmit_Delay $=0$

Basic_Size $=1$

Amp_Gain=1.0

;

; PROTOCOL SETUP

Master_Name=

Carrier_Delay $=7$

Com_Port_Mode=

Reply_Delay $=0$

Ack_Delay $=100$ 


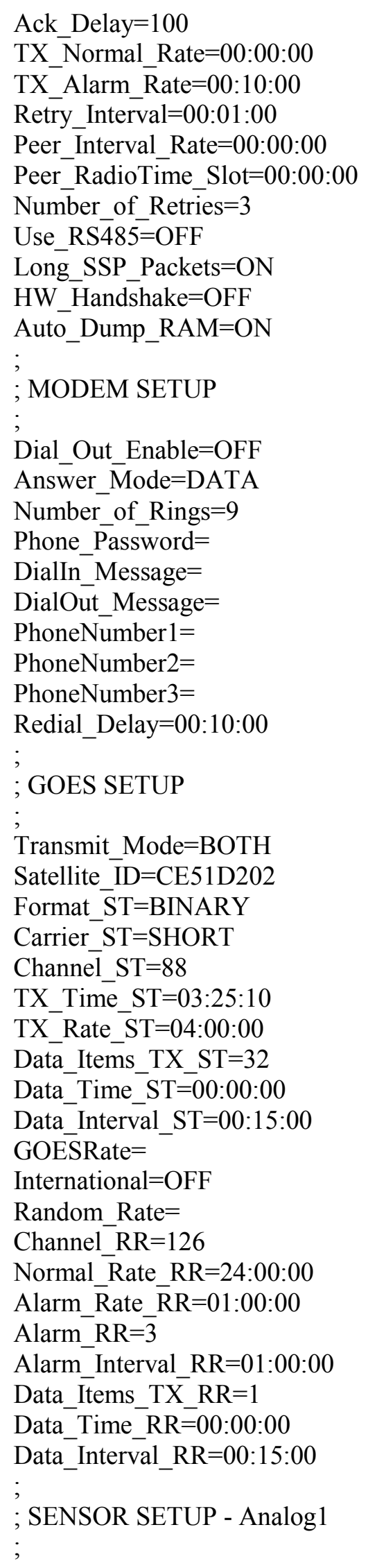




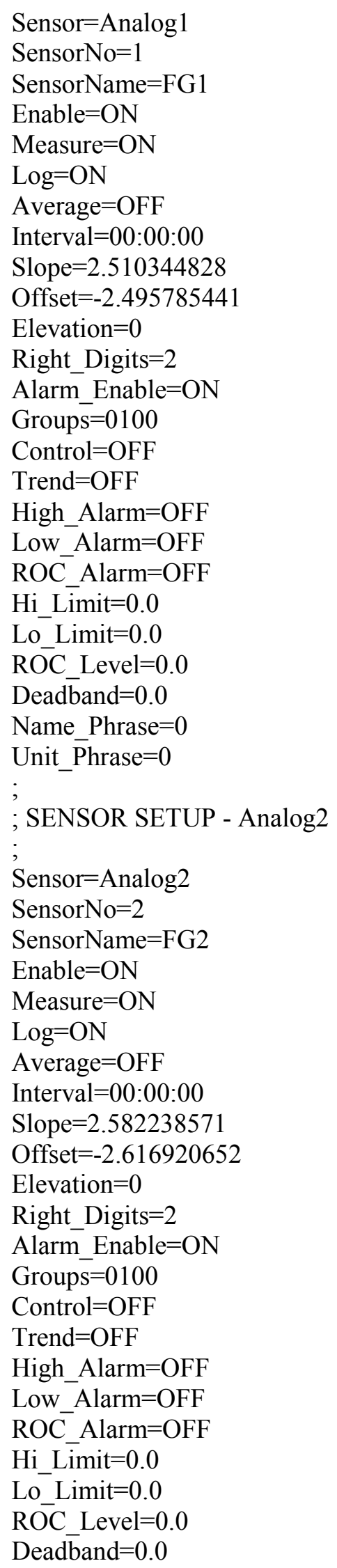




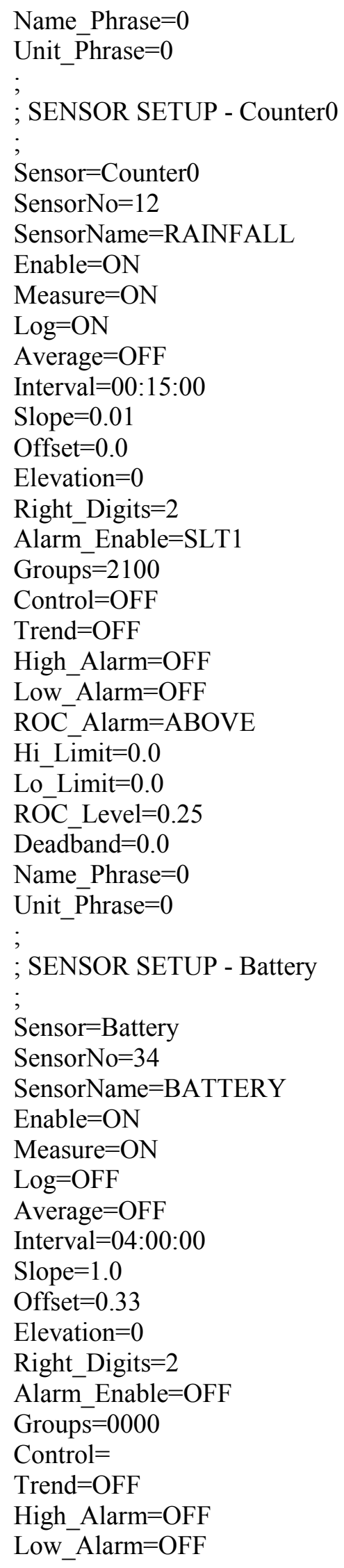


ROC_Alarm $=\mathrm{OFF}$

Hi_Limit $=0.0$

Lo_Limit $=0.0$

ROC Level $=0.0$

Deadband $=0.0$

Name Phrase $=0$

Unit_Phrase $=0$

;

; SENSOR SETUP - SDI0_1

;

Sensor=SDI0 1

SensorNo $=68$

SensorName $=$ ELEVATION

Enable $=\mathrm{ON}$

Measure $=\mathrm{ON}$

$\mathrm{Log}=\mathrm{ON}$

Average $=\mathrm{OFF}$

Interval $=00: 15: 00$

Slope $=1.0$

Offset $=29.23$

Elevation $=0$

Right Digits $=2$

Alarm_Enable $=$ SLT 1

Groups $=2100$

Control $=\mathrm{OFF}$

Trend $=\mathrm{OFF}$

High_Alarm $=\mathrm{OFF}$

Low Alarm $=$ OFF

ROC_Alarm $=\mathrm{OFF}$

Hi_Limit $=0.0$

Lo_Limit $=0.0$

ROC_Level $=0.0$

Deadband $=0.0$

Name Phrase $=0$

Unit_Phrase $=0$ 


\section{Georgetown Lake Near Georgetown, Tex.}

\section{Location}

Lat $30^{\circ} 40^{\prime} 03^{\prime \prime}$, long $97^{\circ} 43^{\prime} 38^{\prime \prime}$, Williamson County, at North San Gabriel Dam on North Fork San Gabriel River, 2.5 mi upstream from Middle Fork San Gabriel River, 3.7 mi northwest of Georgetown, and 4.4 mi upstream from confluence with South Fork San Gabriel River.

\section{Road Log}

From USGS Texas WSC-Fort Worth, follow I-35 south to Georgetown. Exit onto RR 2338 and travel west about $2.7 \mathrm{mi}$ to the brown sign that reads "Lake Georgetown Cedar Breaks Park." Turn left after sign onto DB Wood Rd. Continue on DB Wood Rd. until Lake Overlook Rd. Turn right onto Lake Overlook Rd.; the USACE office is to the right just after turning onto Lake Overlook Rd.

\section{Access}

Before visiting the site, call the Georgetown Dam USACE office at 512-930-5253. Go to the office, where arrangements will be made for USACE staff to escort USGS staff and to open the gate to the road across the top of the dam and the entrance to the intake structure. The intake structure also is protected by an alarm.

\section{Equipment Description}

Refer to table 5, "Georgetown Lake equipment inventory," for a complete list of equipment and to figures 23-29 for equipment wiring diagrams and photographs of equipment. Two main floodgates, two emergency gates, and a low-flow gate are raised and lowered by hydraulic pistons. Floodgates No. 1 and No. 2 are labeled Service 1 and 2; likewise the emergency gates are labeled Emergency 1 and 2. Floodgates No. 1 and No. 2 will be used in this description to be consistent with naming conventions at other dams. The low-flow gate is labeled Low Flow but will be referred to in this description as Low-Flow Gate for consistency as well. All of the gate-sensing equipment is on the seventh floor of the intake structure and is accessible by a small elevator. The elevator entrance is on the floor below the upper deck of the intake structure. Floodgate No. 1 is on the right side of the intake structure (facing upstream) and Floodgate No. 2 is on the left. Similarly, Emergency Gates No. 1 and No. 2 are located on the right and left side (facing upstream), respectively, of the intake structure. Low-Flow Gate is behind the emergency gates.

The positions of the two floodgates, the two emergency gates, and the low-flow gate are displayed on digital displays manufactured by Red Lion Controls. Display labels are Service Gate 1, Service Gate 2, Emergency Gate 1, Emergency Gate 2, and Low Flow. The positions of the two floodgates and the low-flow gate (not the emergency gates) also are recorded by a Sutron 8210 datalogger.

Whessoe Varec 2500B automatic tank level gages indicate the position of both floodgates. Position is relayed to the Sutron 8210 datalogger with Whessoe Varec 8200 
series liquid level transmitters. A steel tape runs from the top of each floodgate to the 2500B tank level gage where it wraps around a storage drum connected to a Neg'ator constant-force spring motor. The Neg'ator spring motor consists of a pre-stressed stainless-steel tape that is formed into a coil and stored on a small storage drum. The free end of the coil is wrapped backwards onto a larger output drum, then fastened to the drum. When the steel tape connected to the top of the gate winds up in the 2500B gage as the gate is raised, the tape of the Neg'ator spring motor will wind up onto the small storage drum. Conversely, when the steel tape connected to the top of the gate unwinds as the gate is lowered, the tape of the Neg'ator spring motor will unwind from the small storage drum and wind up on the output drum. In both instances the Neg'ator spring motor functions to provide a constant amount of force (torque) on the steel tape attached to the gate regardless of the amount of deflection. The movement of the small storage drum rotates a shaft inside the 8200 position transmitter. The shaft is coupled to a worm gear, which in turn drives the shaft of a potentiometer. Rotation of the shaft causes a change in the output current of the transmitter. The variations in current output are carried to the Sutron 8210 datalogger by two wires. At the datalogger, the current is passed through a resistor so a voltage can be measured. The output current of the transmitters varies from 4 to $20 \mathrm{~mA}$.

The Red Lion Controls digital display is different from Vorne displays at other dams (such as Benbrook, Wright Patman, Lake O' the Pines, and Jim Chapman) because the Vorne units only display the value that the datalogger measures and records. However, the Red Lion units are microprocessor-based digital process meters that display signals from inputs ranging from 4 to $20 \mathrm{~mA}$. Therefore, it is possible for the Sutron 8210 to measure and record a value different from the Red Lion units because each requires calibration. Refer to calibration procedures for instructions on how to calibrate the units.

Gate-sensing equipment that serves as a reference for the two floodgates and the low-flow gate is available at Georgetown Dam. The steel tape from the Whessoe Varec gages is attached to a rod that comes out of the top of the hydraulic cylinders. A pointer attached to the rod indicates gate position on a ruler. These are also located on the lower level of the intake structure.

The Sutron 8210 datalogger is powered by a 12-VDC battery, which is charged by an automatic sealed lead-acid battery charger connected to a $120-\mathrm{VAC}$ wall outlet. The position transmitters on the two floodgates and the low flow gate are powered by 24 VDC from the transformer inside the equipment box with the terminal strips (see wiring diagram). The Red Lion units have an input voltage of $120 \mathrm{VAC}$. The wires from the floodgates and low-flow gate and the digital displays pass through DC signal isolators before going to the datalogger. The signal isolator electrically insulates the analog DC output from the position transmitters for 4 to $20 \mathrm{~mA}$ and limits the voltage from the digital display to the Sutron 8210 to prevent damage to the equipment.

The setup file (LAKGEORG.SET) for the datalogger is stored on the RAM card that is kept inside the Sutron equipment box. A hard copy of the setup file is also kept in the station folder.

The positions of Floodgates No. 1 and No. 2 and the Low-Flow Gate are transmitted by satellite and posted on the USACE Web site (http://www.swfwc.usace.army.mil) under Daily Reports/Gate Sensor Report. The USACE reports hourly data; however, the Sutron datalogger measures and records the gate position for the three gates every 15 minutes. 
Floodgates No. 1 and No. 2 are GATE1 and GATE2, respectively, and Low-Flow Gate is LOWFLOW in the Sutron setup file.

\section{Operation and Maintenance}

Operation and maintenance information for the equipment at Georgetown Dam includes descriptions of different procedures required to maintain equipment such as routine inspections, recalibration of Floodgates No. 1 and No. 2 and Low-Flow Gate, recalibration of the Red Lion Controls digital displays, and annual inspections. The purpose of a site visit and the actions taken should be documented in the logbook kept near the datalogger. Include the date, time, actions, and personnel conducting the site visit in the logbook. This section lists some of the potential problems that might occur with the equipment in service and possible solutions to the problems. Refer to the Operations Manuals for the individual pieces of equipment when further detail is required. The information included here is basic operations and maintenance information.

For each visit to the site, personnel should carry all of the necessary tools required to service the equipment. The tools required to perform all of the tasks listed include the following:

- Screwdrivers, flat and Phillips head

- Crescent wrench, 10-in.

- Stepladder, 10-ft

- Electrical tape

- Digital multimeter

- Pliers

- Ruler

- Laptop computer capable of connecting (with RS-232 port and 9-pin cable) to Sutron 8210

- Sutron 8210 Operations Manual

- Whessoe Varec 2500 Installation and Operations Manual

- Whessoe Varec 8200 Installation and Operations Manual

- Red Lion Controls Apollo Intelligent Meter Series Model IMP Instruction Manual

- Battery load tester

- Spare battery

- Flashlight

- Silicone sealant

\section{Procedures during a routine inspection}

- Check the enclosure to the Sutron 8210 datalogger for damage and moisture. If moisture is entering the enclosure, seal any openings with silicone.

- Scroll through the VIEW DATA/LIVE READINGS menu and check that the datalogger is making measurements.

- Check the antennas (data and GPS) and make sure connections are secure and waterproofed. Replace electrical tape around connections if old and brittle.

- Check the battery voltage under the LIVE READINGS menu on the Sutron 8210. 
- If voltage is low (less than $11.5 \mathrm{~V}$ ), test the battery with a load tester and make sure the voltage remains above the recommended voltage specific to the load tester being used. Replace battery as needed.

- Remove drain plug on bottom of position sensor and allow water to drain out.

- Verify that the Whessoe Varec position sensors and the Sutron 8210 datalogger measure the same values (within $0.01 \mathrm{ft}$ ) for the positions of Floodgates No. 1 and No. 2 and the Low-Flow Gate. Next compare the values from the position sensors and the datalogger to the pointer reading. If the position sensors and datalogger values are within $0.01 \mathrm{ft}$ of each other and within $0.05 \mathrm{ft}$ of the pointer reading, no action is required. If the position sensors and the datalogger values differ by more than $0.01 \mathrm{ft}$ or by more than $0.05 \mathrm{ft}$ of the pointer reading, refer to the recalibration procedures.

- Compare the measurements on the Red Lion Controls digital displays to those in the Sutron datalogger. If the measurements are the same (within $0.01 \mathrm{ft}$ ), no action is required. If they are different, consider recalibrating the digital displays. Refer to the recalibration procedures.

- Before leaving the site, make sure the Sutron 8210 is reading ON \& TX under RECORDING.

\section{Procedures to recalibrate Floodgates No. 1 and No. 2 and Low-Flow Gate}

- Completely lower the gate requiring calibration and set the Whessoe Varec position sensor to measure 0.00 . To do this, refer to the Whessoe Varec 2500 Installation and Operations Manual (p. 33-34). If the position sensor measures 0.00 when the gate is lowered completely, only the Sutron requires calibration.

- Caution: Before executing this procedure, make sure the emergency gates are closed. To calibrate the Sutron after setting the Whessoe Varec unit to measure 0.00 , first record the current slope and offset for the gate being calibrated. Next, set the slope and the offset to 1.00 and 0.00 , respectively. With the gate still completely closed, scroll down to SYSTEM SETUP. Press the right arrow once and scroll down to CONFIG SENSORS. Press the right arrow once and scroll down to the gate that is being calibrated. With the correct gate selected, press the right arrow once and scroll down to VALUE. Enter the correct value, which would be 0.00 , then press the SET button. Next open the gate as much as possible so that the instrument will be calibrated over the entire range of gate positions. With the gate open as much as possible, enter the value from the Whessoe Varec dial into the VALUE field and press the SET button. The datalogger will calculate the slope and the offset from the two known positions entered.

- Verify that the Whessoe Varec position sensor and the Sutron 8210 datalogger are now measuring the same position with the gate open as much as possible. Also verify that the measurements are within $0.05 \mathrm{ft}$ of the pointer reading. After verification, close the gate completely and check that both measure 0.00 with the gate completely closed. If so, the calibration is complete; if not, perform the calibration again.

- Whenever a change is made to the setup file in the datalogger, download the new file to the RAM card kept at the site. To do this, insert the RAM card into the socket and turn on the 8210. Scroll down to the DUMP DATA menu. Press the 
right arrow once, then press the down arrow until WRITE CARD SETUP is displayed. Press the SET button and wait for the file to be transferred from the datalogger to the RAM card. To transfer the file from the RAM card to the datalogger, scroll down to the DUMP DATA menu. Press the right arrow once, then press the down arrow until READ CARD SETUP is displayed. Press the right arrow to access the setup file. Transfer the selected file to the datalogger by pressing the SET button.

- Record changes to the slope or the offset in the logbook.

\section{Procedures to recalibrate Red Lion Controls digital displays}

- Completely lower the gate requiring calibration, then press the P button on the digital display for the gate being calibrated. When the $\mathrm{P}$ button is pressed the display will flash "Pro" and "No." Press the up arrow and select " 1 " for programming module \#1 and press the P button (see Red Lion Controls Apollo Intelligent Meter Series Model IMP Instruction Manual, p. 6-7).

- "dECPNt" should appear, prompting the user to select the number of decimal points to report. Press the up and down arrows until " 0.00 " is displayed, then press the $\mathrm{P}$ button to select.

- "round" should appear, prompting the user to select the rounding increments. Press the up and down arrow until " 1 " appears, then press the P button to select.

- "SCALE" should appear next. Press the up and down arrows to select "YES," then press the $\mathrm{P}$ button to select.

- "dSP1" should appear next, prompting the user to enter the value that the digital display should read with the gate closed. Set to 0.00 and press the P button.

- "INP1" should appear next. Press the P button to instruct the instrument to read 0.00 with the input current that the instrument measures.

- "dSP2" should appear next, prompting the user to input the second point. Set this to the maximum allowable value, then press the $\mathrm{P}$ button.

- Raise the gate being calibrated to the value that was input in the previous step. Use the pointer and ruler and the Whessoe Varec dials as references.

- "INP2" should be displayed. Press the P button with the gates raised as much as possible. Pressing the $\mathrm{P}$ button instructs the instrument to read X.XX with the input current that the instrument measures.

- "SEGt" should appear next. Leave this set on 1 and press the P button.

- The display will now return to reading "Pro" and "No." Press the P button to exit the calibration.

- IMPORTANT NOTE. The Red Lion Controls digital displays do not have to be calibrated for the Sutron 8210 to record the correct values. The two are independent of one another. The only reason to calibrate the displays is for USACE staff to be able to read the positions of the gates easily.

- The values measured by the Sutron 8210 and the digital displays might be difficult to match within $0.01 \mathrm{ft}$. 


\section{Procedures during an annual inspection}

- During an inspection the emergency gates are lowered, and the floodgates are raised all the way up and cleaned and inspected. As the gates are lowered after being serviced, check that the position sensors and datalogger measure the same values. If not, follow the instructions to recalibrate the instruments.

- After the inspection, follow all of the procedures during a routine inspection. 
Table 5. Georgetown Lake equipment inventory.

[See table of contents for abbreviated units; --, not available or not applicable]

\begin{tabular}{|c|c|c|c|c|}
\hline $\begin{array}{l}\text { Item } \\
\text { no. }\end{array}$ & Item description & Manufacturer & Model no. & Remarks \\
\hline 1. & Floodgate No. 1 position sensor & Whessoe Varec & $2500 \mathrm{~B}$ & $\begin{array}{l}\text { Gate is GATE1 in Sutron setup and equipment is } \\
\text { labeled Service } 1\end{array}$ \\
\hline 2. & $\begin{array}{l}\text { Floodgate No. } 1 \text { position } \\
\text { transmitter }\end{array}$ & Whessoe Varec & 82000200 & $\begin{array}{l}\text { Analog transmitter with current output of } 4 \text { to } 20 \mathrm{~mA} \\
\text { and input of } 15 \text { to } 48 \text { VDC }\end{array}$ \\
\hline 3. & Wire for position transmitter No. 1 & -- & -- & $200 \mathrm{ft}$ of $18 \mathrm{AWG} / 2$ wires \\
\hline 4. & Floodgate No. 2 position sensor & Whessoe Varec & $2500 \mathrm{~B}$ & $\begin{array}{l}\text { Gate is GATE2 in Sutron setup and equipment is } \\
\text { labeled Service } 2\end{array}$ \\
\hline 5. & $\begin{array}{l}\text { Floodgate No. } 2 \text { position } \\
\text { transmitter }\end{array}$ & Whessoe Varec & 82000200 & $\begin{array}{l}\text { Analog transmitter with current output of } 4 \text { to } 20 \mathrm{~mA} \\
\text { and input of } 15 \text { to } 48 \text { VDC }\end{array}$ \\
\hline 6. & Wire for position transmitter No. 2 & -- & -- & $200 \mathrm{ft}$ of $18 \mathrm{AWG} / 2$ wires \\
\hline 7. & Low-Flow Gate position sensor & Whessoe Varec & 2500B & $\begin{array}{l}\text { Gate is LOWFLOW in Sutron setup and equipment is } \\
\text { labeled LOW FLOW }\end{array}$ \\
\hline 8. & $\begin{array}{l}\text { Low-Flow Gate position } \\
\text { transmitter }\end{array}$ & Whessoe Varec & 82000200 & $\begin{array}{l}\text { Analog transmitter with current output of } 4 \text { to } 20 \mathrm{~mA} \\
\text { and input of } 15 \text { to } 48 \text { VDC }\end{array}$ \\
\hline 9. & $\begin{array}{l}\text { Wire for Low-Flow Gate position } \\
\text { sensor }\end{array}$ & -- & -- & $200 \mathrm{ft}$ of $18 \mathrm{AWG} / 2$ wires \\
\hline 10. & Stage shaft encoder & Sutron & $5600-0530$ & -- \\
\hline 11. & Rain gage & $\begin{array}{l}\text { Texas Electronics, } \\
\text { Inc. }\end{array}$ & TR-525I & -- \\
\hline 12. & Datalogger & Sutron & 8210 & -- \\
\hline 13. & Digital display & Red Lion Controls & IMP & $\begin{array}{l}\text { Displays the position of both floodgates, both } \\
\text { emergency gates, and low-flow gate }\end{array}$ \\
\hline 14. & DC signal isolator & Acromag & 270I-20MA-DIN-NCR & $\begin{array}{l}\text { Electrically insulates analog DC output from position } \\
\text { transmitters to } 4 \text { to } 20 \mathrm{~mA} \text { and limits voltage from } \\
\text { digital display to Sutron } 8210\end{array}$ \\
\hline 15. & Battery & Power Sonic & PS-12550U & $12-\mathrm{V}, 55.0-\mathrm{A}-\mathrm{h}$ battery for Sutron 8210 \\
\hline 16. & Battery charger & Century Mfg. Co. & 1002 & $12-\mathrm{V}, 1.5-\mathrm{A}$ \\
\hline 17. & Transformer & Power-One & HB24-1.2-A & $\begin{array}{l}\text { Converts } 120 \mathrm{VAC} \text { to } 24 \mathrm{VDC} \text { for power to position } \\
\text { transmitters }\end{array}$ \\
\hline 18. & Antenna & Synergetics & YAGI & -- \\
\hline 19. & Antenna cable & Beldon & $8237 \mathrm{RG} 8 / \mathrm{U}$ & 30 -ft cable from Sutron 8210 to antenna \\
\hline 20. & Data transmitter & Sutron & Satlinks & Mounted to side of equipment box with Sutron 8210 \\
\hline 21. & GPS antenna & Trimble & Miniature 5V & Magnetic mount near pole with data antenna \\
\hline 22. & GPS antenna cable & Trimble & -- & Cable comes with antenna \\
\hline
\end{tabular}




\section{Job Hazard Analysis}

Required protective clothing, safety equipment, and supplies: Personal flotation device (PFD), reflective vest, gloves, steel-toed shoes, waders, cell phone, first aid kit, fire extinguisher, rotating or strobe type emergency lights, drinking water.

\begin{tabular}{|c|c|c|}
\hline $\begin{array}{l}\text { Sequence of basic } \\
\text { job steps }\end{array}$ & $\begin{array}{l}\text { Potential } \\
\text { accident or hazard }\end{array}$ & Recommended safe job procedures \\
\hline $\begin{array}{l}\text { Upon job } \\
\text { assignment }\end{array}$ & $\begin{array}{l}\text { Water-related accident or } \\
\text { injury }\end{array}$ & $\begin{array}{l}\text { Employees working in and around water must receive } \\
\text { training specified in WRD Memo } 2000.10 \text {, "Policy for } \\
\text { safety training associated with over-water activities." }\end{array}$ \\
\hline $\begin{array}{l}\text { Loading and } \\
\text { unloading } \\
\text { equipment }\end{array}$ & $\begin{array}{l}\text { Pinched fingers, mashed } \\
\text { toes, or strained back }\end{array}$ & $\begin{array}{l}\text { Be aware of hand placement. Wear protective gloves and } \\
\text { steel-toed shoes. Use proper lifting techniques. Lift with } \\
\text { legs. Use extra caution lifting heavy sounding weights. }\end{array}$ \\
\hline $\begin{array}{l}\text { Driving to and } \\
\text { returning from work } \\
\text { site }\end{array}$ & $\begin{array}{l}\text { Traffic accidents, vehicle } \\
\text { flooding, or drowning }\end{array}$ & $\begin{array}{l}\text { Drivers of USGS vehicles must have Drivers Safety } \\
\text { Training (SM 445-2-H, chap. 16). Be alert to traffic in } \\
\text { area, obey all traffic laws, and reduce speed when weather } \\
\text { conditions are bad. Do not drive across flooded highways } \\
\text { unless water depth and bridge conditions are known to be } \\
\text { safe. }\end{array}$ \\
\hline Parking vehicle & $\begin{array}{l}\text { Personal and vehicle } \\
\text { safety when exiting } \\
\text { vehicle in traffic; bank } \\
\text { collapse or bridge failure }\end{array}$ & $\begin{array}{l}\text { Use rotating or strobe emergency lights, follow site } \\
\text { traffic-control plan, wear DOT Type III reflective vest } \\
\text { when working in or near roadway. Park away from stream } \\
\text { at a safe distance from banks. }\end{array}$ \\
\hline $\begin{array}{l}\text { Set up traffic- } \\
\text { control equipment }\end{array}$ & $\begin{array}{l}\text { Personal and public } \\
\text { safety }\end{array}$ & $\begin{array}{l}\text { Employees working in or near roadways must have Work } \\
\text { Zone Traffic-Control Safety Training. Remain alert to } \\
\text { traffic conditions. }\end{array}$ \\
\hline $\begin{array}{l}\text { Working at field } \\
\text { site }\end{array}$ & Drowning & $\begin{array}{l}\text { Employees are required to wear a PFD when working in, } \\
\text { on, or over any body of water. There are no exemptions } \\
\text { for employees in the Texas WSC. PFDs will be } \\
\text { international orange in color and equipped with reflective } \\
\text { tape in accordance with } 46 \text { CFR } 25.25-15 \text {. Self-inflating } \\
\text { PFDs are not to be worn by employees who have not had } \\
\text { In-Water Safety Training. }\end{array}$ \\
\hline $\begin{array}{l}\text { Working at field } \\
\text { site }\end{array}$ & Trips, slips, and falls & $\begin{array}{l}\text { Follow path clear of obstructions and with minimal slope; } \\
\text { avoid slippery surfaces. Walk cautiously on steep slopes } \\
\text { or paths with loose material. Use appropriate footwear for } \\
\text { the terrain and conditions. Follow the safest, not the } \\
\text { fastest path! }\end{array}$ \\
\hline $\begin{array}{l}\text { Working at field } \\
\text { site }\end{array}$ & $\begin{array}{l}\text { Dehydration, heat } \\
\text { exhaustion, heat stroke, } \\
\text { or sunburn }\end{array}$ & $\begin{array}{l}\text { Drink plenty of water or electrolyte drink. Wear } \\
\text { appropriate clothing. Take occasional breaks and watch } \\
\text { for symptoms of heat exhaustion. Use sun block. }\end{array}$ \\
\hline $\begin{array}{l}\text { Working at field } \\
\text { site }\end{array}$ & Hypothermia or frostbite & $\begin{array}{l}\text { Wear foul-weather gear during winter months. Keep } \\
\text { clothing dry. }\end{array}$ \\
\hline $\begin{array}{l}\text { Working at field } \\
\text { site }\end{array}$ & Snake bites & $\begin{array}{l}\text { Wear appropriate foot and leg protection. Watch path } \\
\text { ahead. Keep area around gage clear of brush. If bitten, } \\
\text { seek immediate medical help. }\end{array}$ \\
\hline
\end{tabular}




\begin{tabular}{|l|l|l|}
\hline $\begin{array}{l}\text { Working at field } \\
\text { site }\end{array}$ & Poisonous plants & $\begin{array}{l}\text { Know how to identify poisonous plants. Wear protective } \\
\text { clothing. Wash and flush exposed areas immediately with } \\
\text { cold water. Wash with degreasing type soap and flush } \\
\text { from skin. Seek medical attention for severe reactions. }\end{array}$ \\
\hline Entering gage house & $\begin{array}{l}\text { Infectious disease or } \\
\text { airborne pollutants; risk } \\
\text { of hantavirus exposure. }\end{array}$ & $\begin{array}{l}\text { Watch for bat or rodent nest and droppings. If nest or } \\
\text { droppings are present, do not disturb dust. Gage should be } \\
\text { periodically cleaned to minimize risk of exposure. See } \\
\text { WRD memo dated 10/28/97, "Preventing hantavirus } \\
\text { disease," and OP memo dated 01/94, "Instructions for } \\
\text { preventing hantavirus disease." }\end{array}$ \\
\hline Entering gage house & Insect or snake bites & $\begin{array}{l}\text { Inspect in and around shelter for harmful insects. Use } \\
\text { wasp or insect spray. Inspect in and around shelter for } \\
\text { snakes prior to entry. }\end{array}$ \\
\hline
\end{tabular}

\section{Site-Specific Job Hazards}

The items listed are safety issues specific to this site that deserve special emphasis.

- Descend in the elevator to the gate-sensing equipment on the seventh floor with USACE staff and notify other staff at office when you expect to be done. Instruct staff remaining above that you will call them when you are out to prevent being stranded below for very long if elevator malfunctions.

- Be careful descending spiral staircase from the upper deck of the intake structure to the elevator.

- Be careful working in or around the digital displays and the equipment boxes with terminal strips A and B (see wiring diagrams). The digital displays are powered with $120 \mathrm{VAC}$ as well as the transformer in the equipment box with the terminal strips. 
Figure 23. Georgetown Lake Sutron 8210 wiring panel
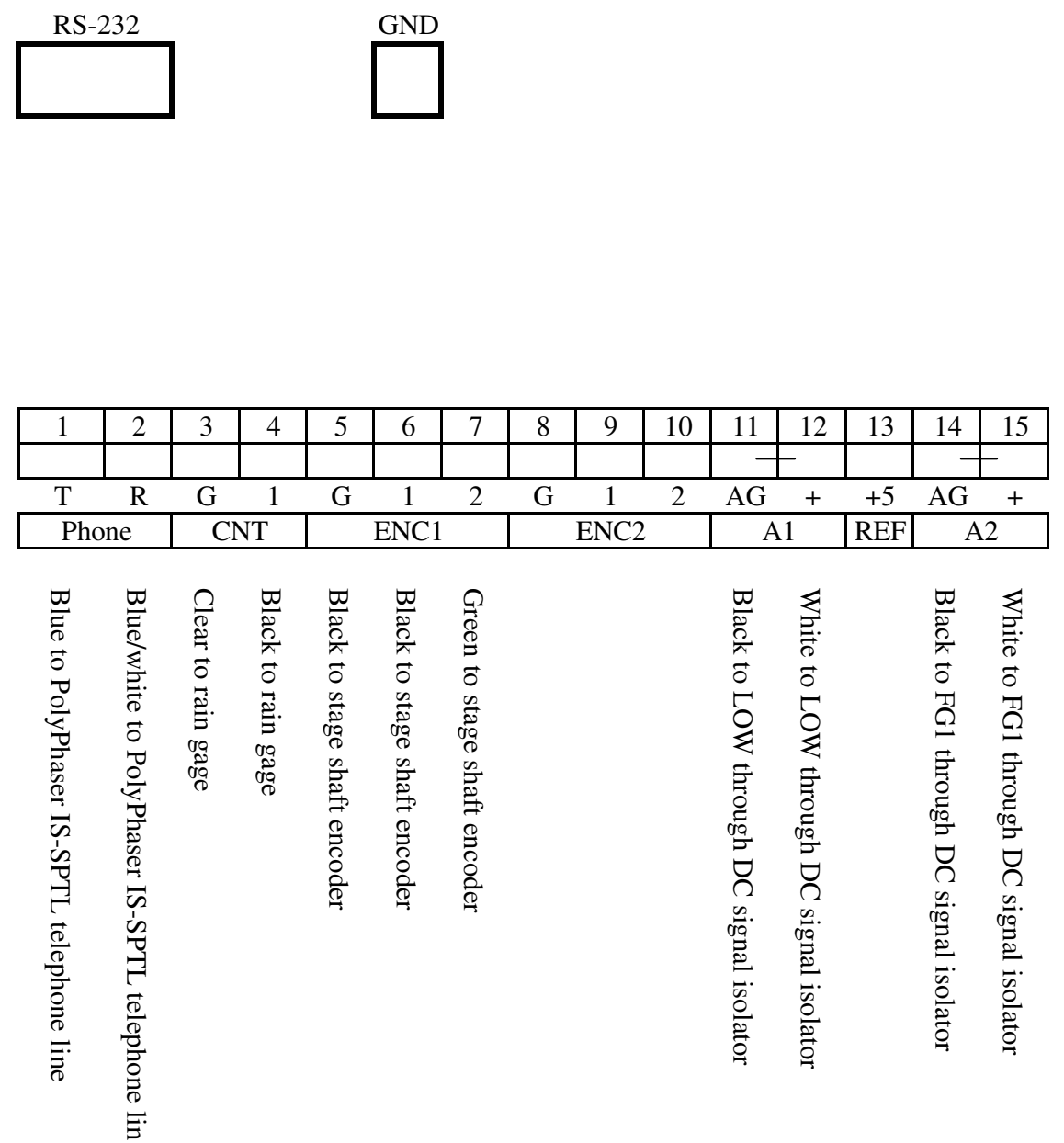

Note: LOW, Low-Flow Gate. FG1, Floodgate No. 1.

FG2, Floodgate No. 2.

+ denotes a resistor between the two ports of the Sutron

\begin{tabular}{|c|c|c|c|c|c|c|c|c|c|c|c|c|c|c|}
\hline \multicolumn{2}{|c|}{ Ext Batt } & \multicolumn{2}{|c|}{ RS485 } & \multicolumn{3}{|c|}{ SDI-12 } & \multicolumn{3}{|c|}{ SDI-12 } & \multicolumn{5}{|c|}{ Digital Output } \\
\hline$\overline{\mathrm{G}}$ & + & $\overline{\mathrm{A}}$ & $\bar{B}$ & $\overline{\mathrm{G}}$ & + & $\bar{D}$ & $\bar{G}$ & + & $\bar{D}$ & 1 & 2 & 3 & 4 & 5 \\
\hline & & & & & & & & & & & & & & \\
\hline 1 & 2 & 3 & $\overline{4}$ & 5 & 6 & 7 & 8 & 9 & 10 & 11 & $\overline{12}$ & 13 & 14 & 15 \\
\hline
\end{tabular}

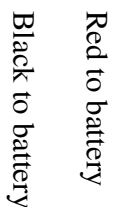

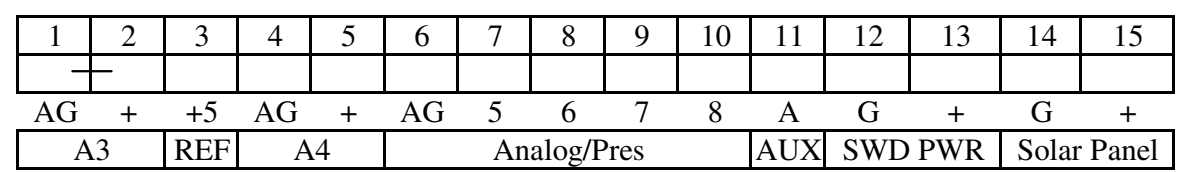

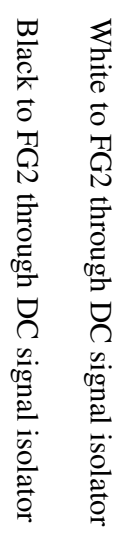

20
0
0
0
$n$
0
0
00
0
0
0
0
0
0
0
0
0
0
0 
Figure 24. Georgetown Lake Equipment Wiring Diagram
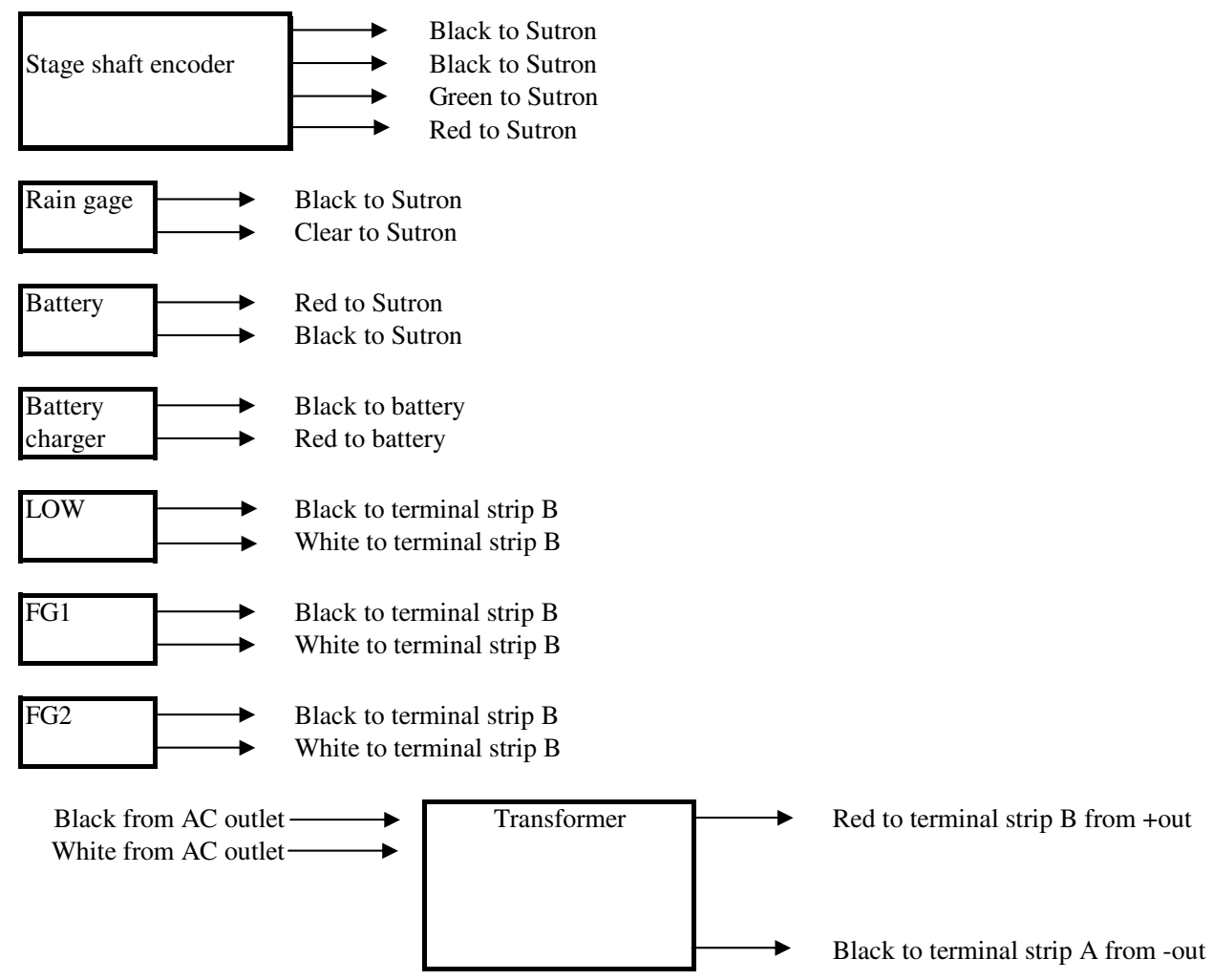

\begin{tabular}{l|c|r|} 
White from Sutron A2 & + & DC signal isolator \\
Black from Sutron A2 & A & + \\
\end{tabular}

\begin{tabular}{l|c|c|}
\hline White from Sutron A3 + & DC signal isolator & B \\
Black from Sutron A3 & - & $+\begin{array}{l}\text { White to FG2 through terminal strip B } \\
\text { Black to FG2 through terminal strip A }\end{array}$
\end{tabular}

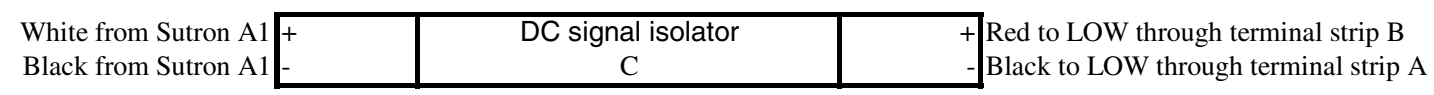

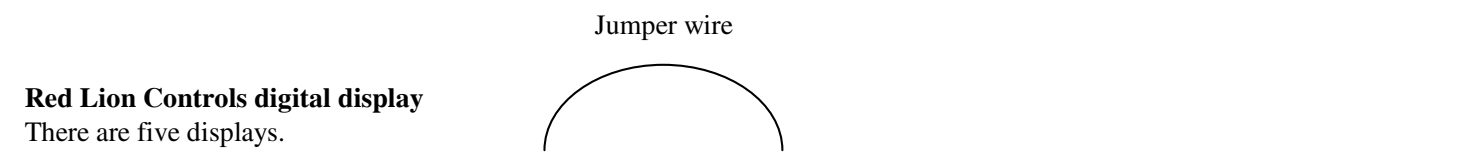

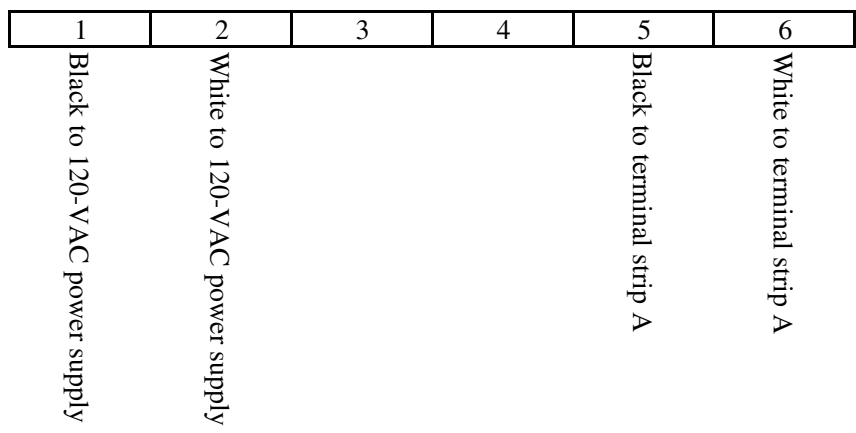

Note: $\quad$ FG1, Floodgate No. 1.

FG2, Floodgate No. 2.

LOW, Low-Flow Gate. 
Figure 24. Georgetown Lake Equipment Wiring Diagram--Continued

\section{Terminal strip A}

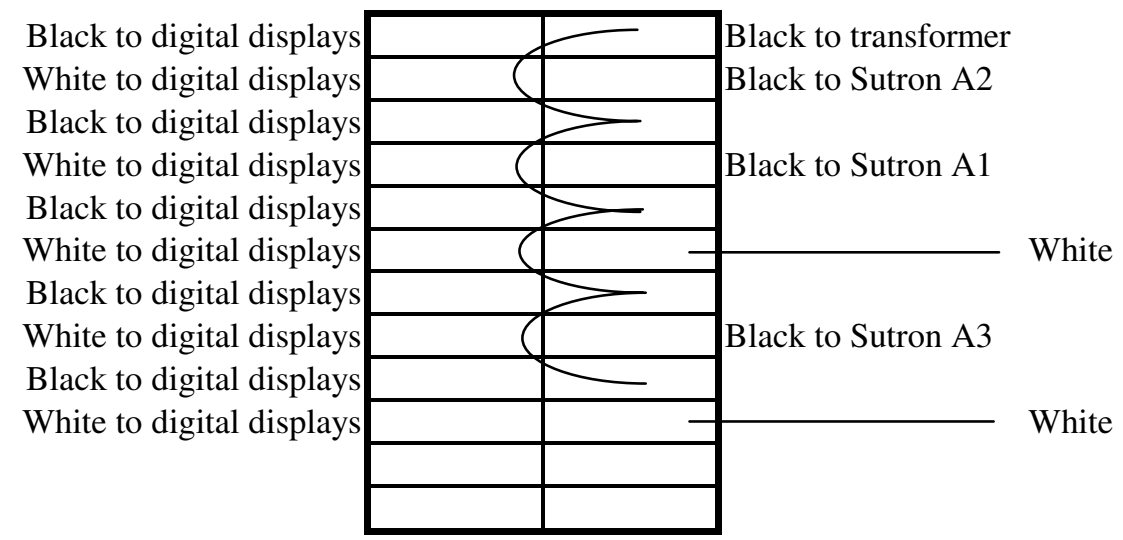

Terminal strip B

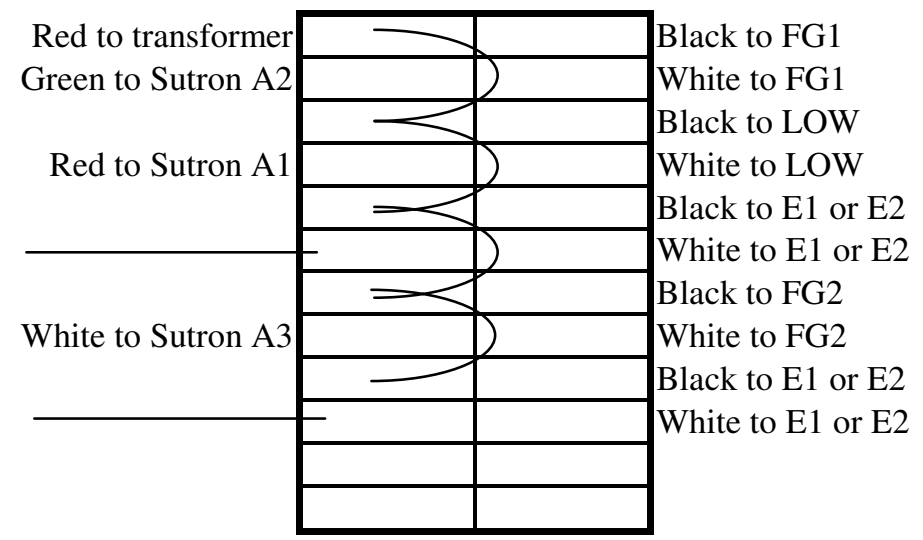

Note: $\quad$ FG1, Floodgate No. 1.

LOW, Low-Flow Gate.

E1, Emergency Gate No. 1.

E2, Emergency Gate No. 2.

FG2, Floodgate No. 2. 


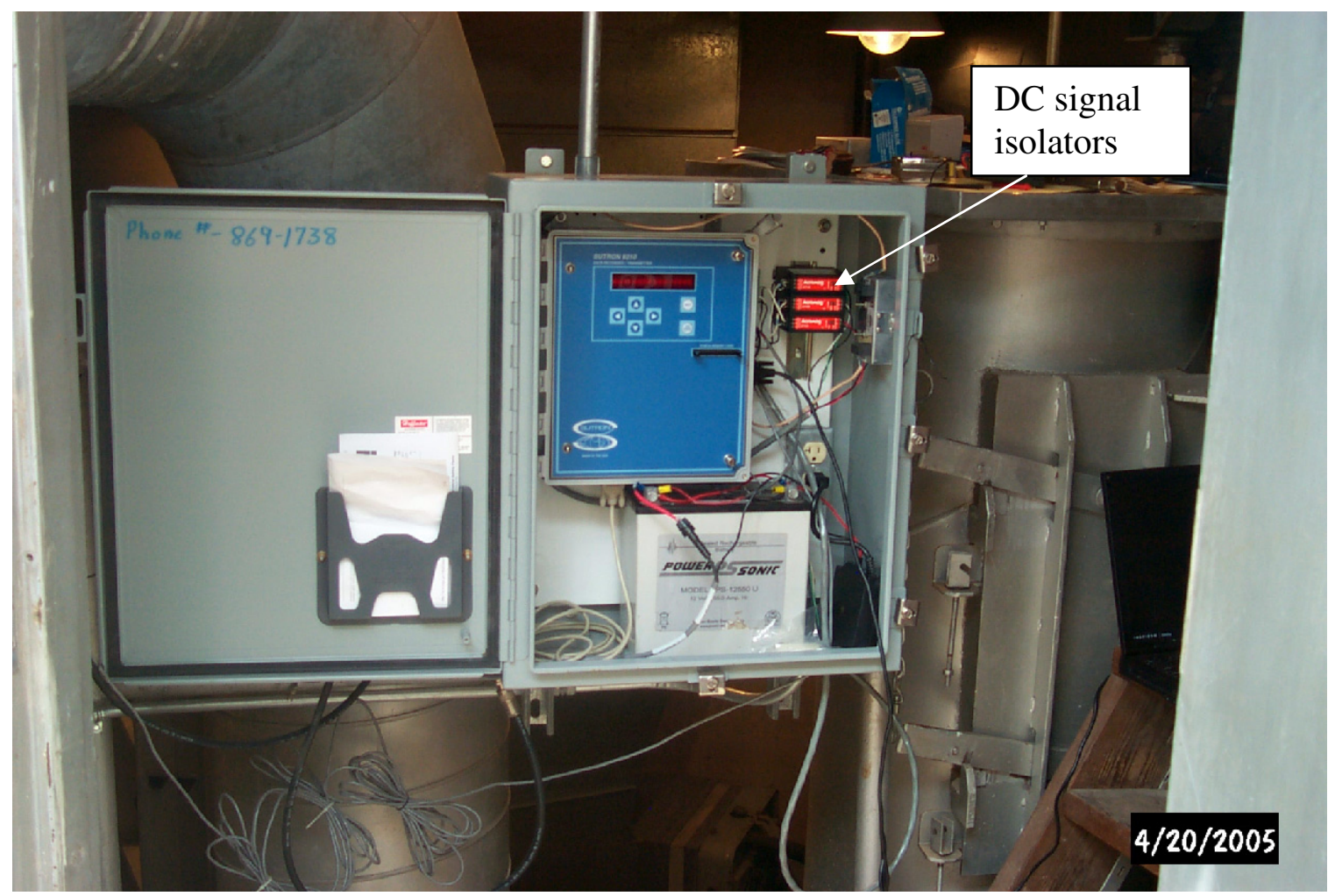

Figure 25. Equipment box with Sutron 8210 and battery at Georgetown Lake.

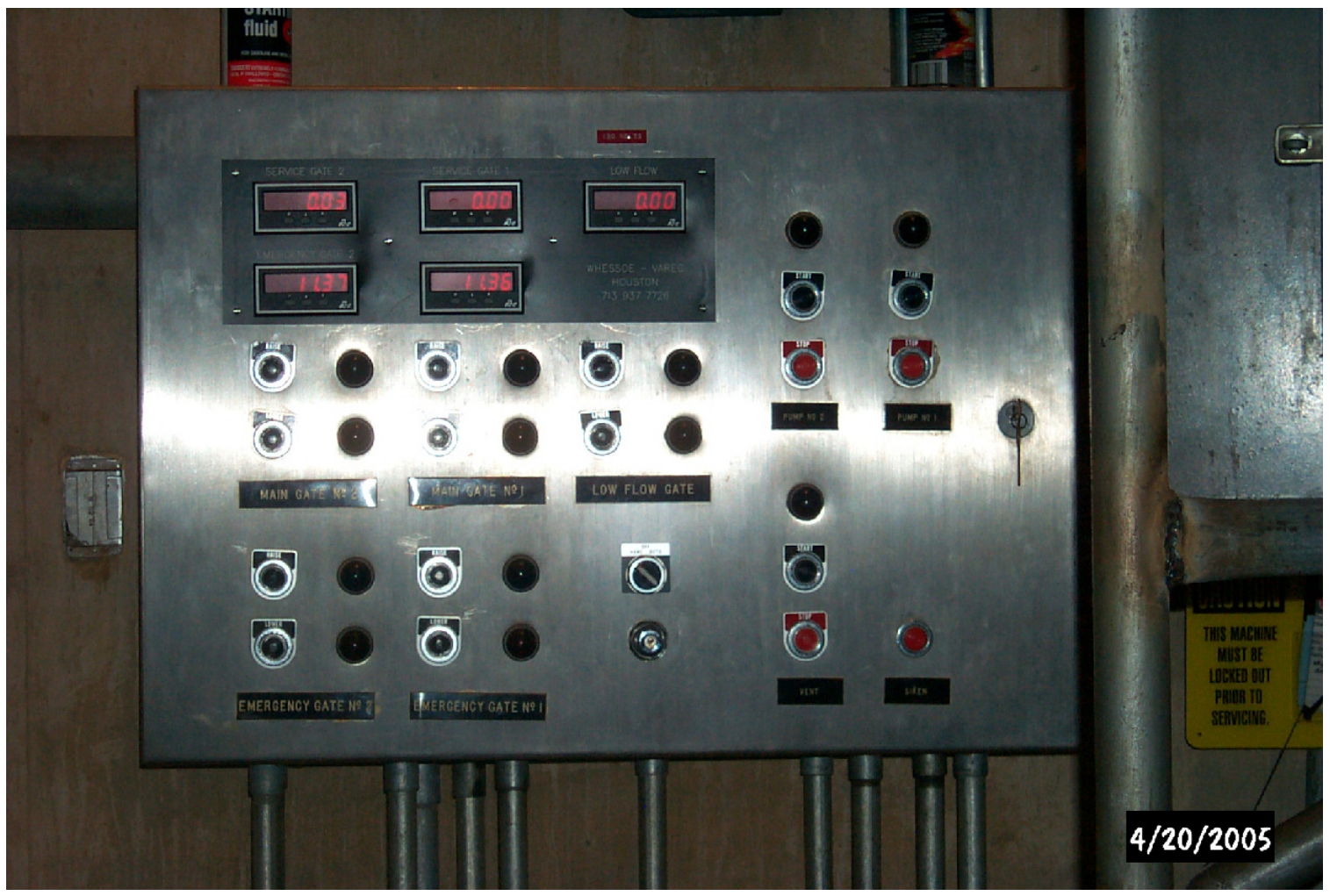

Figure 26. Digital displays and controls at Georgetown Lake. 


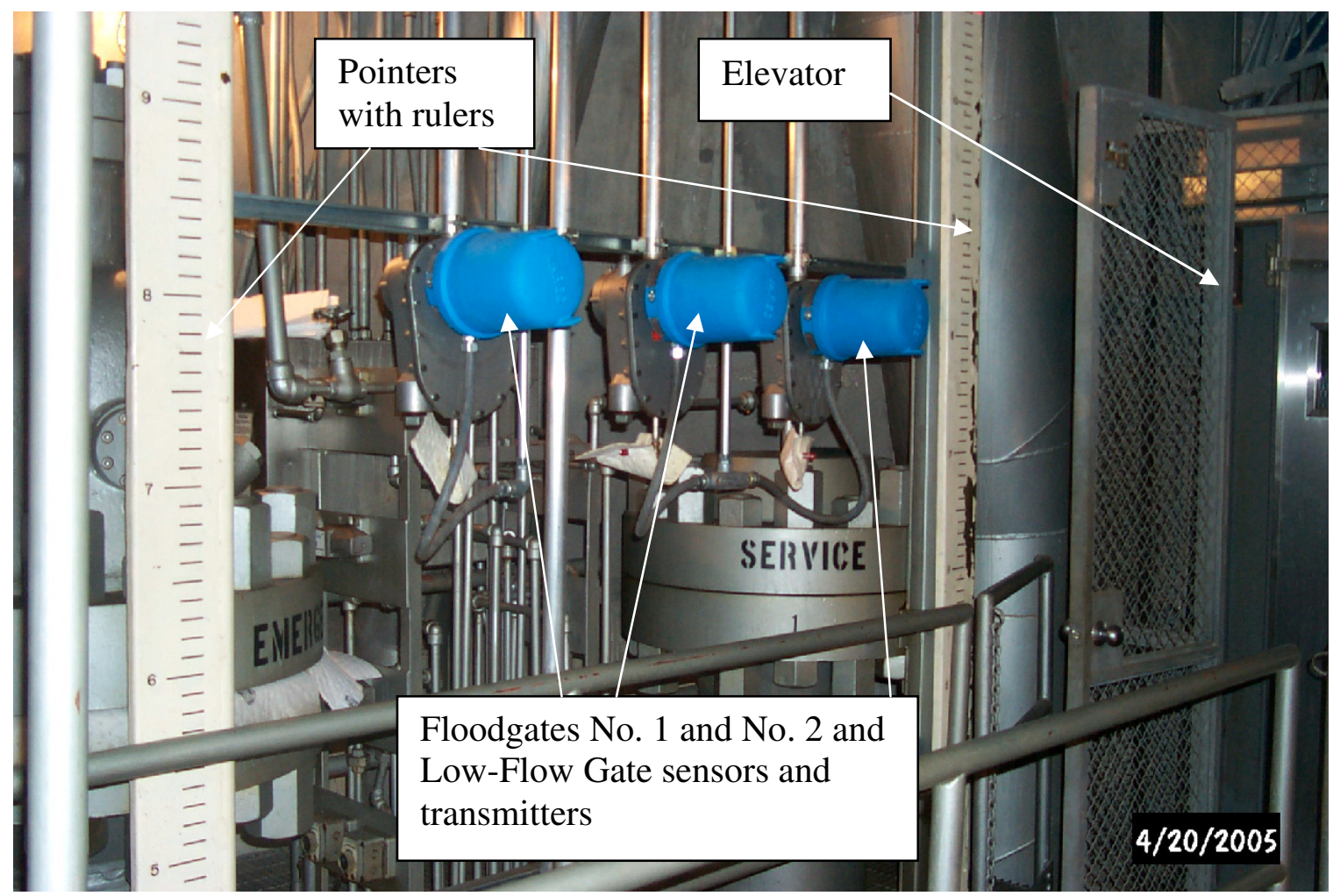

Figure 27. Gate-sensing equipment at Georgetown Lake. 


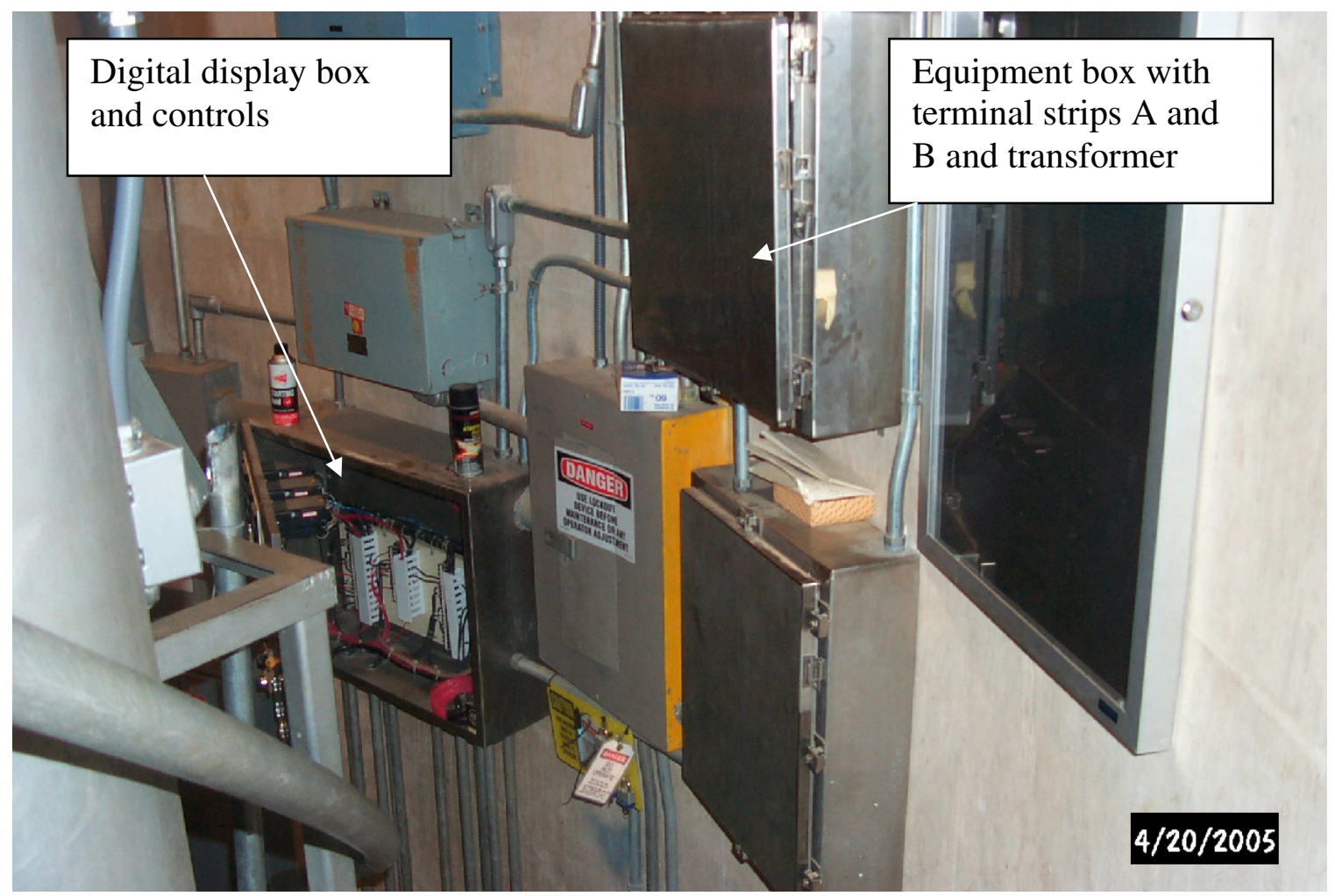

Figure 28. Equipment boxes with terminal strips connecting equipment and digital displays at Georgetown Lake (see fig. 24).

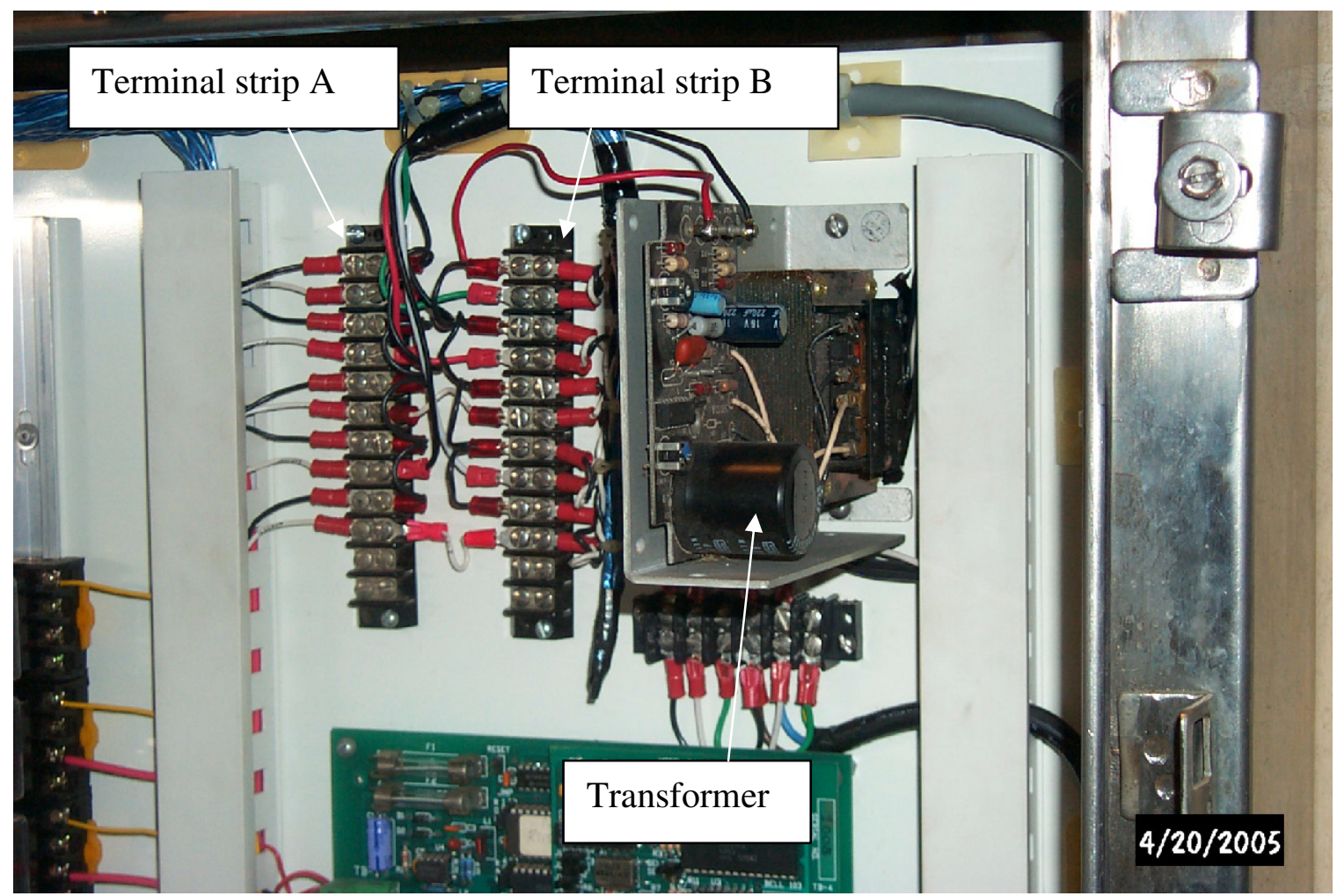

Figure 29. Terminal strips connecting equipment at Georgetown Lake. 


\section{Georgetown Lake Sutron 8210 Setup File (LAKGEORG.SET)}

; 8210/8200 ASCII setup file, can be converted back to a .SET file with WSETMGR.EXE

;

; MAIN SETUP

;

Setup_Version $=$ V6X

Unit_ID=LAKGEORG

Measurement_Interval=00:30:00

Sampling_Interval=00:00:00

Measurement_Time $=00: 00: 00$

Sampling_Time $=00: 00: 00$

Switched_Power_Time $=00: 00: 00$

Samples_to_Average $=0$

Measurements_per_Log $=1$

Switched_Power_Mode=ON

Recording $=\mathrm{ON}$

Basic_Run_Interval=00:00:00

Basic_Run_Time $=00: 00: 00$

Password=

Number_Resets $=9$

Log_Size $=124928$

Rom_Checksum=57134

;

; EEROM SETUP

Serial_Port_Mode=USER

User_Baud_Rate $=9600$

Radio_Baud_Rate $=1200$

Com_Baud_Rate $=9600$

Transfer_Baud_Rate $=9600$

SDI_Baud_Rate $=1200$

Enter_Key_Reqd=OFF

Log_Dump_Mode=ALL-BIN

User_Time_Limit $=900$

Power_Delay $=1$

Analog_Delay $=5$

Pressure_Delay $=5$

Auto_Startup_Keys=

Time_Format=NORMAL

Date_Format=MDY

Term_Xmit_Delay $=0$

Basic_Size $=1$

Amp_Gain=1.0

;

; PROTOCOL SETUP

Master_Name $=$

Carrier_Delay $=7$

Com_Port_Mode $=$

Reply_Delay $=0$

Ack_Delay $=100$ 


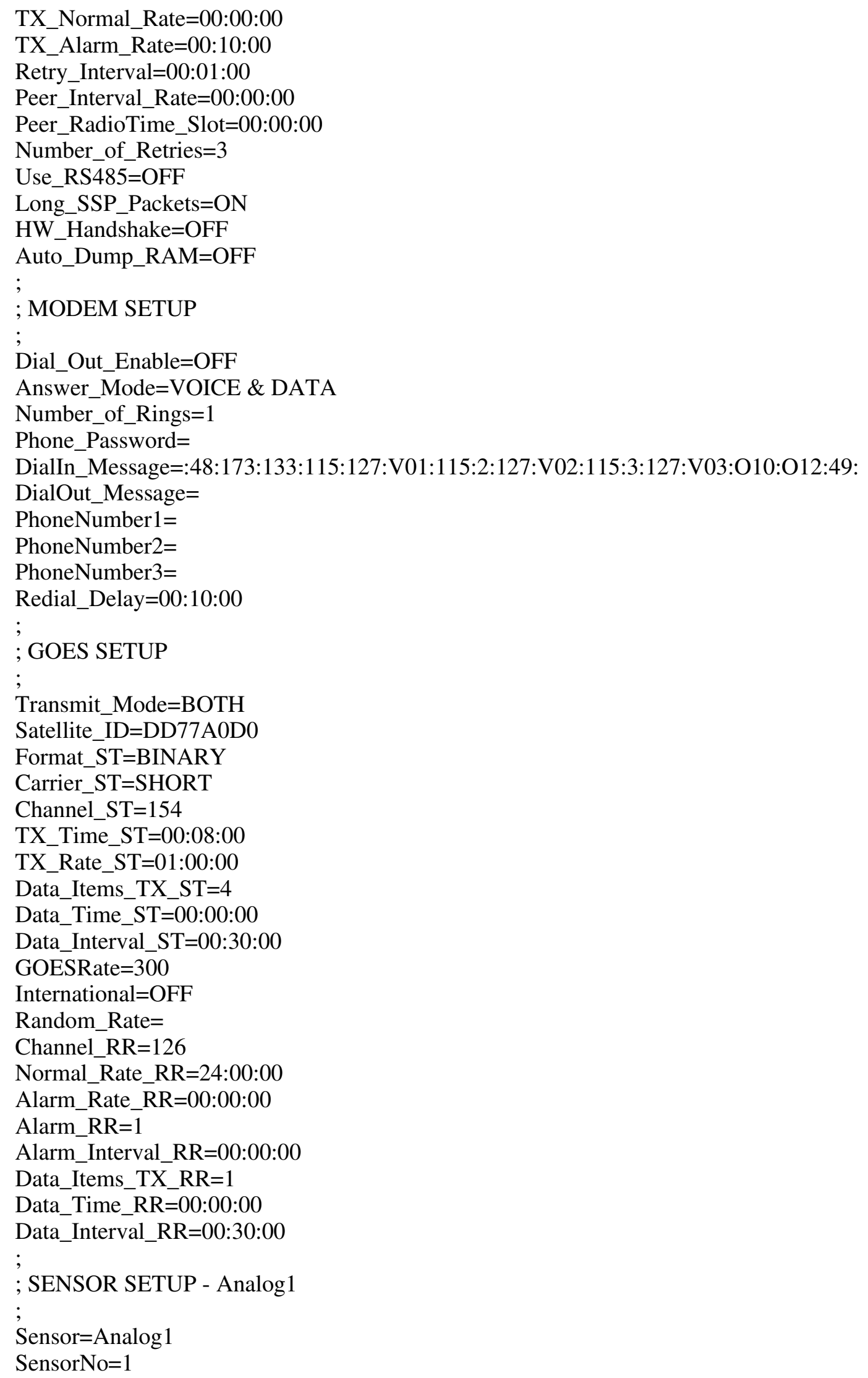




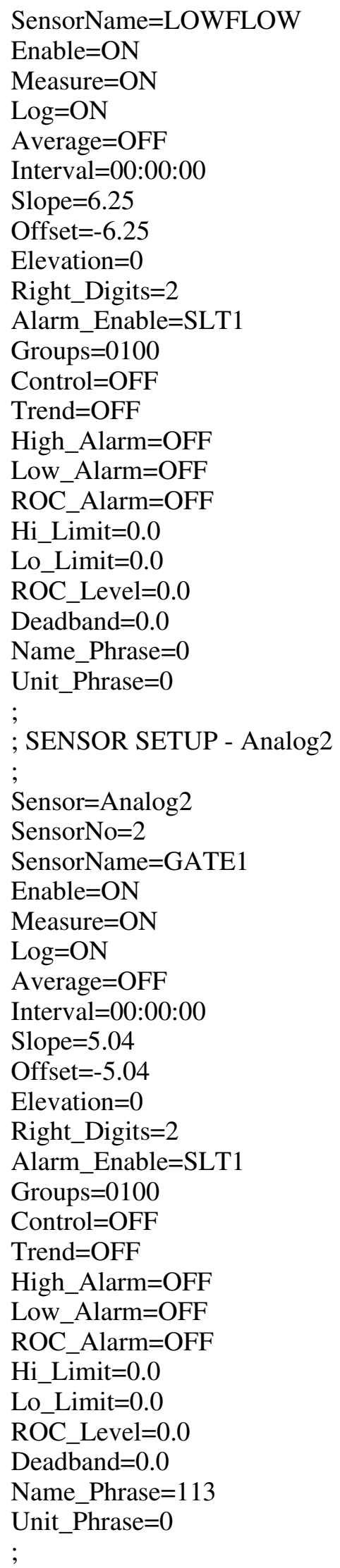




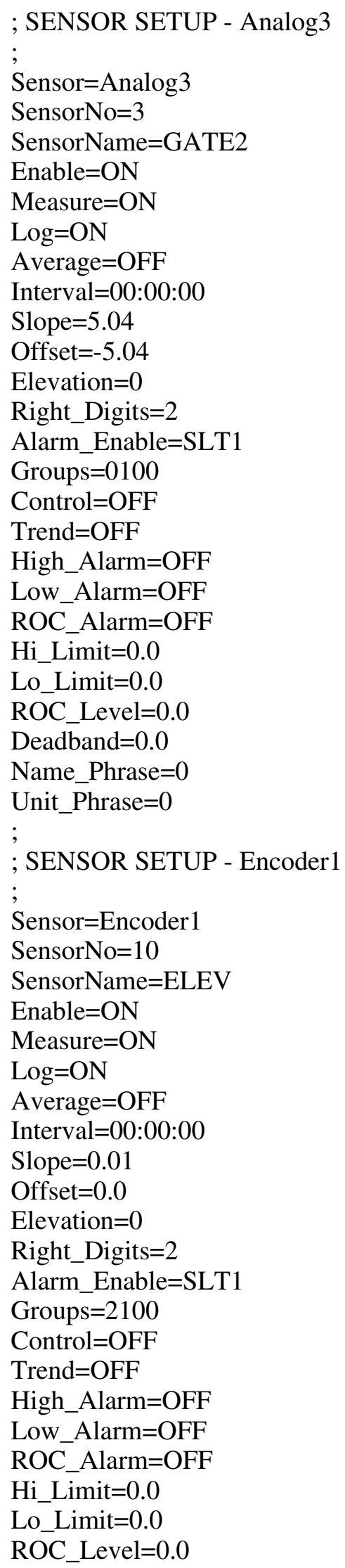




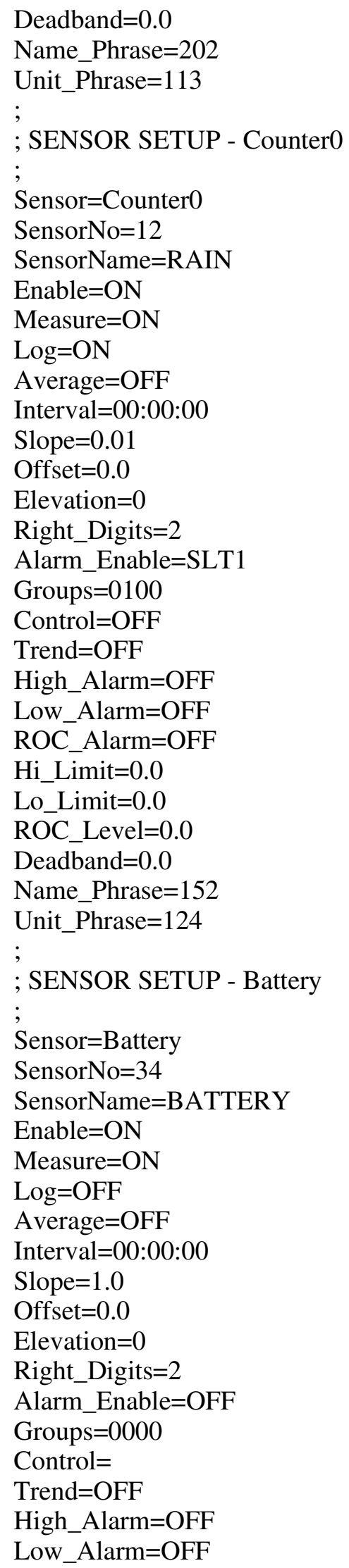


ROC_Alarm $=\mathrm{OFF}$

Hi_Limit $=0.0$

Lo_Limit $=0.0$

ROC_Level $=0.0$

Deadband $=0.0$

Name_Phrase $=0$

Unit_Phrase $=0$ 


\section{Granger Lake Near Granger, Tex.}

\section{Location}

Lat 3041'34", long 97¹9'34", Williamson County, at Granger Dam on the San Gabriel River, $1.5 \mathrm{mi}$ south of Friendship, 2.2 mi upstream from Willis Creek, $7.1 \mathrm{mi}$ east of Granger, and 31.9 mi upstream from mouth.

\section{Road Log}

From USGS Texas WSC-Fort Worth, take I-35 south to Temple. Exit onto SH 36 and travel south to SH 95. Exit onto SH 95 and travel south about 25 mi to FM 1331. Follow FM 1331 east about $8 \mathrm{mi}$ and turn left after the large brown sign pointing towards Granger Dam and Wilson Fox Park. The intake structure is about halfway across the dam, and the USACE office is on the north end of the dam.

\section{Access}

Before visiting the site, call the Granger Dam USACE office at 512-859-2668. USACE staff will escort USGS staff and open the gate to the intake structure. The intake structure also is protected by an alarm. Before going to the intake structure, the USACE staff will ask for identification such as a driver's license; someone from the USACE office will remain with USGS staff while the site is serviced.

\section{Equipment Description}

Refer to table 6, "Granger Lake equipment inventory," for a complete list of equipment and to figures 30-35 for equipment wiring diagrams and photographs of equipment. Two main floodgates are raised and lowered by hydraulic pistons. The floodgates are labeled 1 and 2 and will be referred to as Floodgates No. 1 and No. 2 in this description to be consistent with naming conventions used at other dams. Floodgate No. 1 is on the right side of the intake structure (facing upstream) and Floodgate No. 2 is on the left. Both are located on the lower level of the intake structure that is accessed by descending the two sets of spiral staircases on the right side (facing upstream) of the top deck. The low-flow gate (not labeled) is on the top deck of the intake structure between four selective withdrawal gates; a Limitorque electric valve operator raises and lowers the gate. The four selective withdrawal gates allow water to be pulled from different depths through the low-flow gate. They are labeled 1 through 4.

The gates (flood and low flow) use Shand \& Jurs 92020 automatic tank level gages to indicate the position of the gates. Position is relayed to a Sutron 8210 datalogger with Whessoe Varec 8200 series liquid level transmitters.

A steel tape runs from the top of each gate to the 92020 tank level gage, where it wraps around a storage drum connected to a Neg' ator constant-force spring motor. The Neg'ator spring motor consists of a prestressed stainless steel tape that is formed into a coil and stored on a small storage drum. The free end of the coil is wrapped backwards onto a larger output drum and then fastened to the drum. When the steel tape connected to the top of the gate winds up in the 92020 gage as the gate is raised, the tape of the Neg'ator spring motor will wind up onto the small storage drum. Conversely, when the 
steel tape connected to the top of the gate unwinds as the gate is lowered, the tape of the Neg'ator spring motor will unwind from the small storage drum and wind up on the output drum. In both instances the Neg'ator spring motor functions to provide a constant amount of force (torque) on the steel tape attached to the gate regardless of the amount of deflection. The movement of the small storage drum rotates a shaft inside the 8200 position transmitter. The shaft is coupled to a worm gear, which in turn drives the shaft of a potentiometer. Rotation of the shaft causes a change in the output current of the transmitter. The variations in current output are carried to the Sutron 8210 datalogger by two wires. At the datalogger, the current is passed through a resistor so the voltage can be measured. The output current of the transmitters varies from 4 to $20 \mathrm{~mA}$.

Gate-sensing equipment that serves as a reference for the two floodgates is not available at Granger Dam. The Shand \& Jurs and Whessoe Varec units are assumed to measure the true position of the gates.

The Low-Flow Gate has an independent reference. The steel tape that winds up in the 92020 gage passes through a clear tube with a ruler. The tape is attached to an eyebolt and as the gate is raised and lowered the eyebolt moves up and down along the ruler. Read the gate position as the point on the ruler where the top of the eyebolt is positioned. Currently (2005), the ruler is warped and should not be used as a reference until replaced.

The Sutron 8210 datalogger is powered by a 12-VDC battery, which is charged by an automatic sealed lead-acid battery charger connected to a 120-VAC wall outlet. The position transmitters are powered by 24 VDC from a transformer inside the equipment box with the Sutron 8210. Varec offers an onboard power source that would eliminate the transformer and AC power inside the equipment box. Instead, AC power would run directly to the position transmitter and be converted to 24 VDC by an internal transformer.

The setup file (GRANGER.SET) for the datalogger is stored on the RAM card that is kept inside the Sutron equipment box. A hard copy of the setup file is also kept in the station folder.

The positions of Floodgates No. 1 and No. 2 and the low-flow gate are transmitted by satellite and posted on the USACE Web site (http://www.swf-wc.usace.army.mil) under Daily Reports/Gate Sensor Report. The USACE reports hourly data; however, the Sutron datalogger measures and records the gate position for the three gates every 15 minutes.

Floodgates No. 1 and No. 2 are SERGATE1 and SERGATE2, respectively, and the low-flow gate is LOFLOGAT in the Sutron setup file.

\section{Operation and Maintenance}

Operation and maintenance information for the equipment at Granger Dam includes descriptions of different procedures required to maintain equipment such as routine inspections, recalibration of Floodgates No. 1 and No. 2, recalibration of the lowflow gate, and annual inspections. The purpose of a site visit and the actions taken should be documented in the logbook kept near the datalogger. Include the date, time, actions, and personnel conducting the site visit in the logbook. This section lists some of the potential problems that might occur with the equipment in service and possible solutions to the problems. Refer to the Operations Manuals for the individual pieces of equipment when further detail is required. The information included here is basic operations and maintenance information. 
For each visit to the site, personnel should carry all of the necessary tools required to service the equipment. The tools required to perform all of the tasks listed include the following:

- Screwdrivers, flat and Phillips head

- Crescent wrench, 10-in

- Stepladder, 10-ft

- Electrical tape

- Digital multimeter

- Pliers

- Ruler

- Laptop computer capable of connecting (with RS-232 port and 9-pin cable) to Sutron 8210

- Sutron 8210 Operations Manual

- Shand \& Jurs 92020 and 92021 Instruction Manuals

- Whessoe Varec 8200 Installation and Operations Manual

- Battery load tester

- Spare battery

- Flashlight

- Silicone sealant

\section{Procedures during a routine inspection}

- Check the enclosure to the Sutron 8210 datalogger for damage and moisture. If moisture is entering the enclosure, seal any openings with silicone.

- Scroll through the VIEW DATA/LIVE READINGS menu and check that the datalogger is making measurements.

- Check the antennas (data and GPS) and make sure connections are secure and waterproofed. Replace electrical tape around connections if old and brittle.

- Check the battery voltage under the LIVE READINGS menu on the Sutron 8210.

- If voltage is low (less than $11.5 \mathrm{~V}$ ), test the battery with a load tester and make sure the voltage remains above the recommended voltage specific to the load tester being used. Replace battery as needed.

- Remove drain plug on bottom of position sensor and allow water to drain out.

- Verify that the Shand \& Jurs position sensors and the Sutron 8210 datalogger measure the same values for the positions of Floodgates No. 1 and No. 2 and the low-flow gate. If they measure the same (within $0.01 \mathrm{ft}$ ), no action is required. If the values differ, refer to the recalibration procedures.

- Before leaving the site, make sure the Sutron 8210 is reading ON \& TX under RECORDING.

\section{Procedures to recalibrate Floodgates No. 1 and No. 2 and the low-flow gate}

- Completely lower the gate requiring calibration and set the Shand \& Jurs position sensor to measure 0.00 . To do this, open the counter access cover on top of the unit above the dial window. Hold the notched wheel, located to the right of the increments wheel, and turn the increments wheel until the counter measures the correct position, 0.00 . If the position sensor measures 0.00 when the gate is lowered completely, only the Sutron requires calibration. 
- Caution: Before executing this procedure, make sure the emergency bulkheads have been lowered. To calibrate the Sutron after setting the Shand \& Jurs unit to measure 0.00 , first record the current slope and offset for the gate being calibrated. Next, set the slope and the offset to 1.00 and 0.00 , respectively. With the gate still completely closed, scroll down to SYSTEM SETUP. Press the right arrow once and scroll down to CONFIG SENSORS. Press the right arrow once and scroll down to the gate that is being calibrated. With the correct gate selected, press the right arrow once and scroll down to VALUE. Enter the correct value, which would be 0.00 , then press the SET button. Next, open the gate as much as possible so that the instrument will be calibrated over the entire range of gate positions. With the gate open as much as possible, enter the value from the Shand \& Jurs dial into the VALUE field and press the SET button. The datalogger will calculate the slope and the offset from the two known positions entered.

- Verify that the Shand \& Jurs position sensor and the Sutron 8210 datalogger are now measuring the same position with the gate open as much as possible. After verification, close the gate completely and check that both measure 0.00 with the gate completely closed. If so, the calibration is complete; if not, perform the calibration again.

- Whenever a change is made to the setup file in the datalogger, download the new file to the RAM card kept at the site. To do this, insert the RAM card into the socket and turn on the 8210. Scroll down to the DUMP DATA menu. Press the right arrow once, then press the down arrow until WRITE CARD SETUP is displayed. Press the SET button and wait for the file to be transferred from the datalogger to the RAM card. To transfer the file from the RAM card to the datalogger, scroll down to the DUMP DATA menu. Press the right arrow once and then press the down arrow until READ CARD SETUP is displayed. Press the right arrow to access the setup file. Transfer the selected file to the datalogger by pressing the SET button.

- Record changes to the slope or the offset in the logbook.

\section{Procedures during an annual inspection}

- During an inspection the emergency bulkheads are lowered and the floodgates are raised all the way up and cleaned and inspected. As the gates are lowered after being serviced, check that the position sensors and datalogger measure the same values. If not, follow the instructions to recalibrate the instruments.

- After the inspection, follow all of the procedures during a routine inspection. 
Table 6. Granger Lake equipment inventory.

[See table of contents for abbreviated units; --, not available or not applicable]

\begin{tabular}{|c|c|c|c|c|}
\hline Item no. & Item description & Manufacturer & Model no. & Remarks \\
\hline 1. & $\begin{array}{l}\text { Floodgate No. } 1 \text { position } \\
\text { sensor }\end{array}$ & Shand \& Jurs & 92020 & $\begin{array}{l}\text { Gate is SERGATE1 in Sutron setup and equipment is } \\
\text { labeled with numeral } 1\end{array}$ \\
\hline 2. & $\begin{array}{l}\text { Floodgate No. } 1 \text { position } \\
\text { transmitter }\end{array}$ & Whessoe Varec & 82000200 & $\begin{array}{l}\text { Analog transmitter with current output of } 4 \text { to } 20 \mathrm{~mA} \\
\text { and input of } 15 \text { to } 48 \mathrm{VDC}\end{array}$ \\
\hline 3. & $\begin{array}{l}\text { Wire for position transmitter } \\
\text { No. } 1\end{array}$ & -- & -- & $20 \mathrm{ft}$ of $18 \mathrm{AWG} / 6$ wires but only 2 wires are used \\
\hline 4. & $\begin{array}{l}\text { Floodgate No. } 2 \text { position } \\
\text { sensor }\end{array}$ & Shand \& Jurs & 92020 & $\begin{array}{l}\text { Gate is SERGATE2 in Sutron setup and equipment is } \\
\text { labeled with numeral } 2\end{array}$ \\
\hline 5 . & $\begin{array}{l}\text { Floodgate No. } 2 \text { position } \\
\text { transmitter }\end{array}$ & Whessoe Varec & 82000200 & $\begin{array}{l}\text { Analog transmitter with current output of } 4 \text { to } 20 \mathrm{~mA} \\
\text { and input of } 15 \text { to } 48 \text { VDC }\end{array}$ \\
\hline 6. & $\begin{array}{l}\text { Wire for position transmitter } \\
\text { No. } 2\end{array}$ & -- & -- & $20 \mathrm{ft}$ of $18 \mathrm{AWG} / 6$ wires but only 2 wires are used \\
\hline 7. & Low-glow gate position sensor & Shand \& Jurs & 92020 & $\begin{array}{l}\text { Gate is LOFLOGAT in Sutron setup; no label on } \\
\text { equipment }\end{array}$ \\
\hline 8. & $\begin{array}{l}\text { Low-flow gate position } \\
\text { transmitter }\end{array}$ & Whessoe Varec & 82000100 & -- \\
\hline 9. & $\begin{array}{l}\text { Wire for low-flow gate } \\
\text { position sensor }\end{array}$ & -- & -- & $85 \mathrm{ft}$ of $18 \mathrm{AWG} / 6$ wires but only 2 wires are used \\
\hline 10. & Stage shaft encoder & Handar & $436 \mathrm{~A}$ & -- \\
\hline 11. & Rain gage & $\begin{array}{l}\text { Texas Electronics, } \\
\text { Inc. }\end{array}$ & TR-525I & -- \\
\hline 12. & Datalogger & Sutron & 8210 & -- \\
\hline 13. & Battery & Douglas Batteries & Guardian DG12-55JH & $12-\mathrm{V}, 55.0-\mathrm{A}-\mathrm{h}$ battery for Sutron 8210 \\
\hline 14. & Battery charger & -- & -- & No label or marker on charger \\
\hline 15 . & Transformer & Power-One & HB24-1.2-A & $\begin{array}{l}\text { Converts } 120 \text { VAC to } 24 \text { VDC for power to position } \\
\text { transmitters }\end{array}$ \\
\hline 16. & Antenna & Sutron & YAGI & $402 \mathrm{MHz}$ \\
\hline 17. & Antenna cable & Beldon & $8237 \mathrm{RG} 8 / \mathrm{U}$ & 60-ft cable from Sutron 8210 to antenna \\
\hline 18. & Antenna polyphaser & PolyPhaser & IS-B6OLN-C2-ME & -- \\
\hline 19. & Data transmitter & Sutron & Satlink & -- \\
\hline 20. & GPS antenna & Trimble & Miniature 5V & Magnetic mount on side of shelter \\
\hline 21. & GPS antenna cable & Trimble & -- & Cable comes with antenna \\
\hline
\end{tabular}




\section{Job Hazard Analysis}

Required protective clothing, safety equipment, and supplies: Personal flotation device (PFD), reflective vest, gloves, steel-toed shoes, waders, cell phone, first aid kit, fire extinguisher, rotating or strobe type emergency lights, drinking water.

\begin{tabular}{|c|c|c|}
\hline $\begin{array}{l}\text { Sequence of basic } \\
\text { job steps }\end{array}$ & $\begin{array}{l}\text { Potential } \\
\text { accident or hazard }\end{array}$ & Recommended safe job procedures \\
\hline $\begin{array}{l}\text { Upon job } \\
\text { assignment }\end{array}$ & $\begin{array}{l}\text { Water-related accident or } \\
\text { injury }\end{array}$ & $\begin{array}{l}\text { Employees working in and around water must receive } \\
\text { training specified in WRD Memo 2000.10, "Policy for } \\
\text { safety training associated with over-water activities." }\end{array}$ \\
\hline $\begin{array}{l}\text { Loading and } \\
\text { unloading } \\
\text { equipment }\end{array}$ & $\begin{array}{l}\text { Pinched fingers, mashed } \\
\text { toes, or strained back }\end{array}$ & $\begin{array}{l}\text { Be aware of hand placement. Wear protective gloves and } \\
\text { steel-toed shoes. Use proper lifting techniques. Lift with } \\
\text { legs. Use extra caution lifting heavy sounding weights. }\end{array}$ \\
\hline $\begin{array}{l}\text { Driving to and } \\
\text { returning from work } \\
\text { site }\end{array}$ & $\begin{array}{l}\text { Traffic accidents, vehicle } \\
\text { flooding, or drowning }\end{array}$ & $\begin{array}{l}\text { Drivers of USGS vehicles must have Drivers Safety } \\
\text { Training (SM 445-2-H, chap. 16). Be alert to traffic in } \\
\text { area, obey all traffic laws, and reduce speed when weather } \\
\text { conditions are bad. Do not drive across flooded highways } \\
\text { unless water depth and bridge conditions are known to be } \\
\text { safe. }\end{array}$ \\
\hline Parking vehicle & $\begin{array}{l}\text { Personal and vehicle } \\
\text { safety when exiting } \\
\text { vehicle in traffic; bank } \\
\text { collapse or bridge failure }\end{array}$ & $\begin{array}{l}\text { Use rotating or strobe emergency lights, follow site } \\
\text { traffic-control plan, wear DOT Type III reflective vest } \\
\text { when working in or near roadway. Park away from stream } \\
\text { at a safe distance from banks. }\end{array}$ \\
\hline $\begin{array}{l}\text { Set up traffic- } \\
\text { control equipment }\end{array}$ & $\begin{array}{l}\text { Personal and public } \\
\text { safety }\end{array}$ & $\begin{array}{l}\text { Employees working in or near roadways must have Work } \\
\text { Zone Traffic-Control Safety Training. Remain alert to } \\
\text { traffic conditions. }\end{array}$ \\
\hline $\begin{array}{l}\text { Working at field } \\
\text { site }\end{array}$ & Drowning & $\begin{array}{l}\text { Employees are required to wear a PFD when working in, } \\
\text { on, or over any body of water. There are no exemptions } \\
\text { for employees in the Texas WSC. PFDs will be } \\
\text { international orange in color and equipped with reflective } \\
\text { tape in accordance with } 46 \text { CFR } 25.25-15 \text {. Self-inflating } \\
\text { PFDs are not to be worn by employees who have not had } \\
\text { In-Water Safety Training. }\end{array}$ \\
\hline $\begin{array}{l}\text { Working at field } \\
\text { site }\end{array}$ & Trips, slips, and falls & $\begin{array}{l}\text { Follow path clear of obstructions and with minimal slope; } \\
\text { avoid slippery surfaces. Walk cautiously on steep slopes } \\
\text { or paths with loose material. Use appropriate footwear for } \\
\text { the terrain and conditions. Follow the safest, not the } \\
\text { fastest path! }\end{array}$ \\
\hline $\begin{array}{l}\text { Working at field } \\
\text { site }\end{array}$ & $\begin{array}{l}\text { Dehydration, heat } \\
\text { exhaustion, heat stroke, } \\
\text { or sunburn }\end{array}$ & $\begin{array}{l}\text { Drink plenty of water or electrolyte drink. Wear } \\
\text { appropriate clothing. Take occasional breaks and watch } \\
\text { for symptoms of heat exhaustion. Use sun block. }\end{array}$ \\
\hline $\begin{array}{l}\text { Working at field } \\
\text { site }\end{array}$ & Hypothermia or frostbite & $\begin{array}{l}\text { Wear foul-weather gear during winter months. Keep } \\
\text { clothing dry. }\end{array}$ \\
\hline $\begin{array}{l}\text { Working at field } \\
\text { site }\end{array}$ & Snake bites & $\begin{array}{l}\text { Wear appropriate foot and leg protection. Watch path } \\
\text { ahead. Keep area around gage clear of brush. If bitten, } \\
\text { seek immediate medical help. }\end{array}$ \\
\hline
\end{tabular}




\begin{tabular}{|l|l|l|}
\hline $\begin{array}{l}\text { Working at field } \\
\text { site }\end{array}$ & Poisonous plants & $\begin{array}{l}\text { Know how to identify poisonous plants. Wear protective } \\
\text { clothing. Wash and flush exposed areas immediately with } \\
\text { cold water. Wash with degreasing type soap and flush } \\
\text { from skin. Seek medical attention for severe reactions. }\end{array}$ \\
\hline Entering gage house & $\begin{array}{l}\text { Infectious disease or } \\
\text { airborne pollutants; risk } \\
\text { of hantavirus exposure. }\end{array}$ & $\begin{array}{l}\text { Watch for bat or rodent nest and droppings. If nest or } \\
\text { droppings are present, do not disturb dust. Gage should be } \\
\text { periodically cleaned to minimize risk of exposure. See } \\
\text { WRD memo dated 10/28/97, "Preventing hantavirus } \\
\text { disease," and OP memo dated 01/94, "Instructions for } \\
\text { preventing hantavirus disease." }\end{array}$ \\
\hline Entering gage house & Insect and snake bites & $\begin{array}{l}\text { Inspect in and around shelter for harmful insects. Use } \\
\text { wasp or insect spray. Inspect in and around shelter for } \\
\text { snakes prior to entry. }\end{array}$ \\
\hline
\end{tabular}

\section{Site-Specific Job Hazards}

The items listed are safety issues specific to this site that deserve special emphasis.

- Use caution when placing hands inside metal box containing Sutron datalogger. The two wires (white and red) from the AC terminal box to the transformer are hot (120 VAC).

- Use caution descending the two sets of spiral staircases to go from the upper deck of the intake structure to the lower level where the gate sensing equipment for the main floodgates is located. 
Figure 30. Granger Lake Sutron 8210 wiring panel.
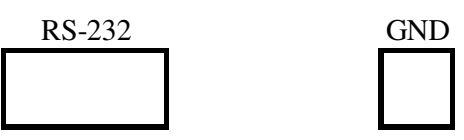

\begin{tabular}{|c|c|c|c|c|c|c|c|c|c|c|c|c|c|c|}
\hline Ext Batt & \multicolumn{1}{c|}{ RS485 } & \multicolumn{3}{c|}{ SDI-12 } & \multicolumn{5}{c|}{ SDI-12 } & \multicolumn{5}{c|}{ Digital Output } \\
\hline \begin{tabular}{|c|c|c|c|c|c|c|c|c|c|c|c|c|}
\hline \\
\hline
\end{tabular} & + & A & B & G & + & D & G & + & D & 1 & 2 & 3 & 4 & 5 \\
\hline 1 & 2 & 3 & 4 & 5 & 6 & 7 & 8 & 9 & 10 & 11 & 12 & 13 & 14 & 15 \\
\hline
\end{tabular}

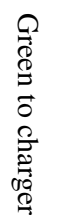

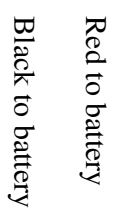

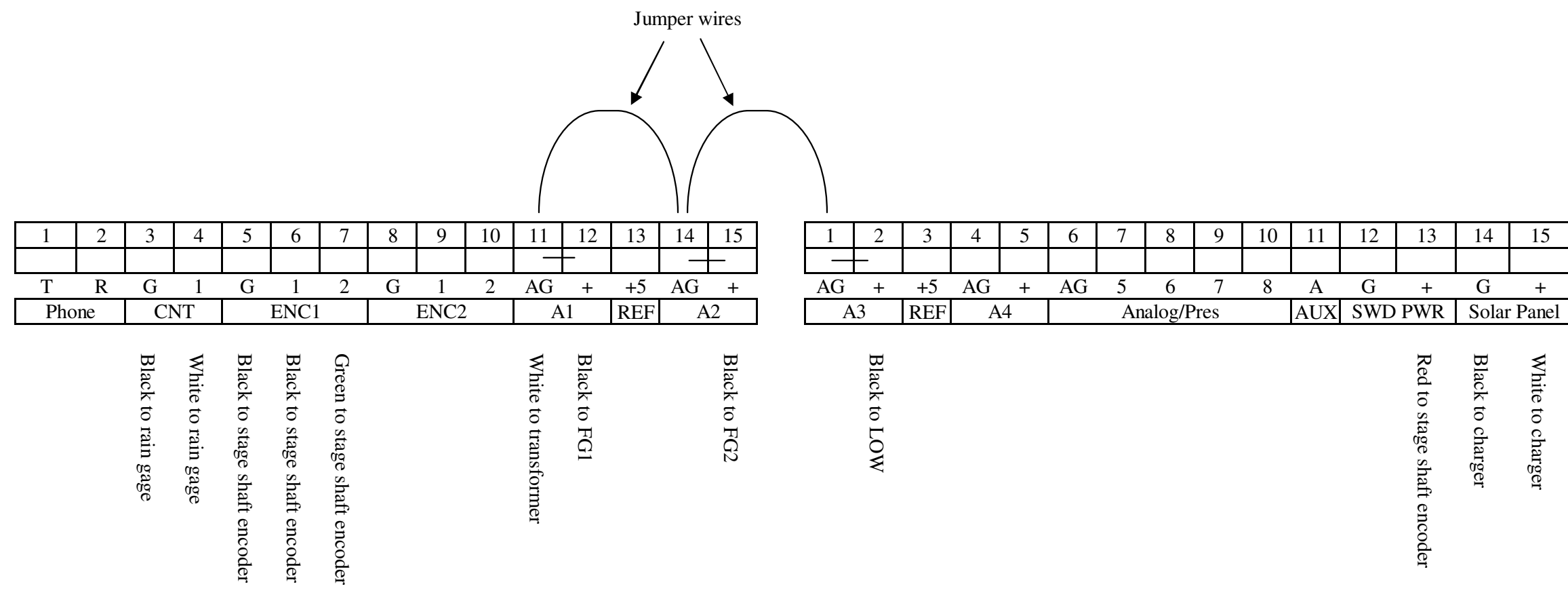

Note: FG1, Floodgate No. 1 or SERGATE1 (Sutron setup file name). FG2, Floodgate No. 2 or SERGATE2 (Sutron setup file name). LOW, low-flow gate or LOFLOGAT (Sutron setup file name).

+ denotes a resistor between the two ports of the Sutron 
Figure 31. Granger Lake Equipment wiringdiagram.

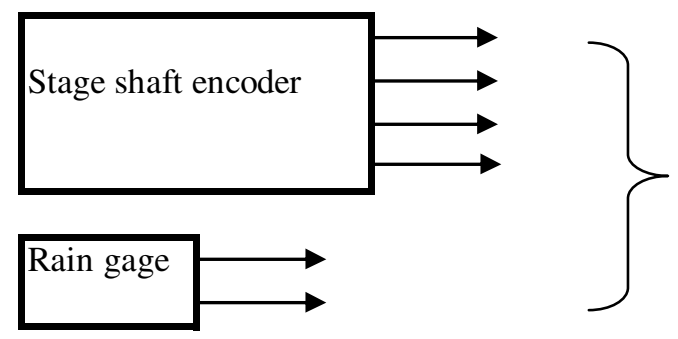

The six wires from the stage shaft encoder and the rain gage join a larger $18 \mathrm{AWG}$ wire with six separate wires and go to the Sutron.
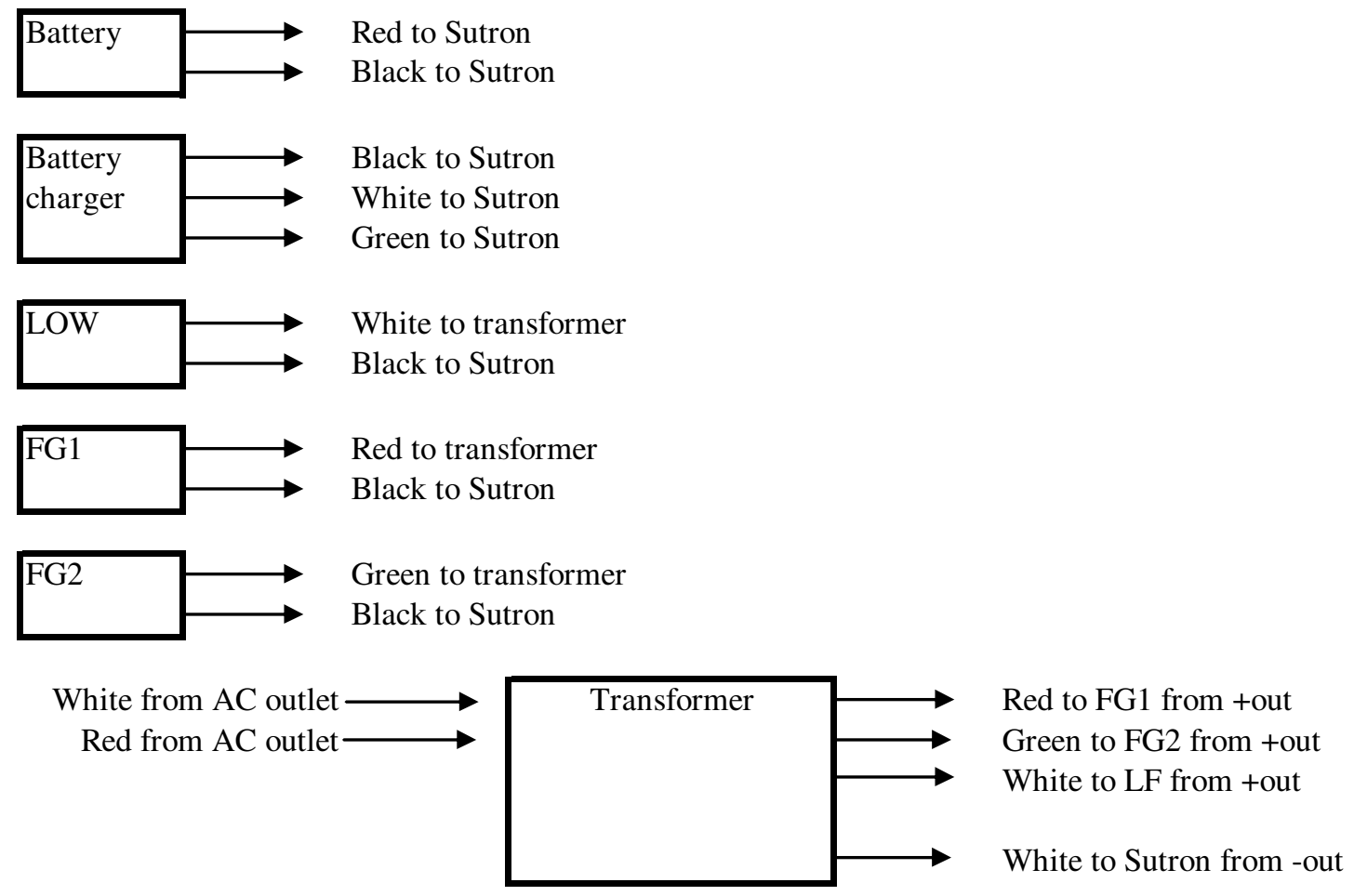

Note: $\quad$ LOW, low-flow gate or LOFLOGAT (Sutron setup file name).

FG1, Floodgate No. 1 or SERGATE1 (Sutron setup file name).

FG2, Floodgate No. 2 or SERGATE2 (Sutron setup file name). 


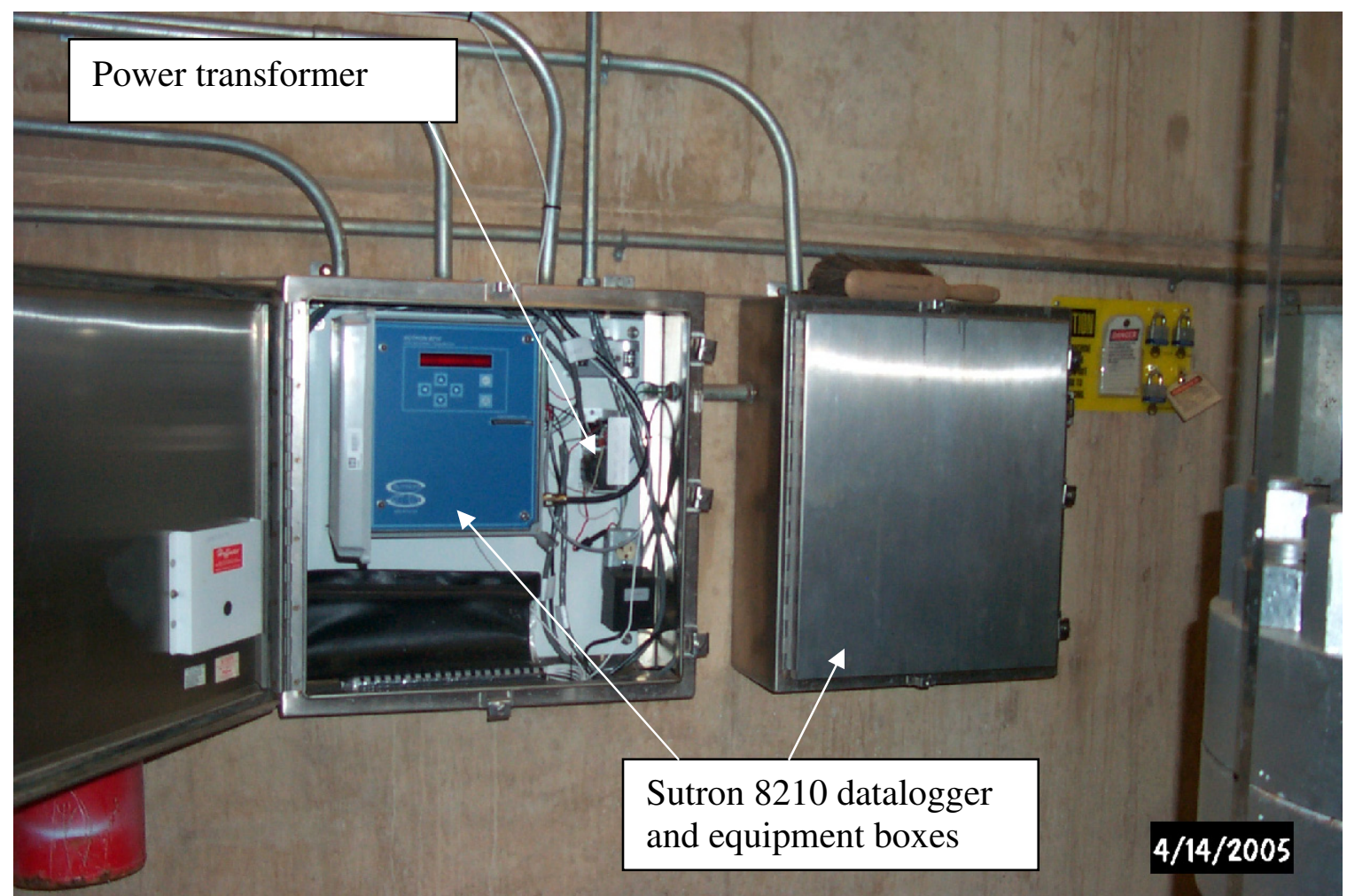

Figure 32. Equipment boxes at Granger Lake.

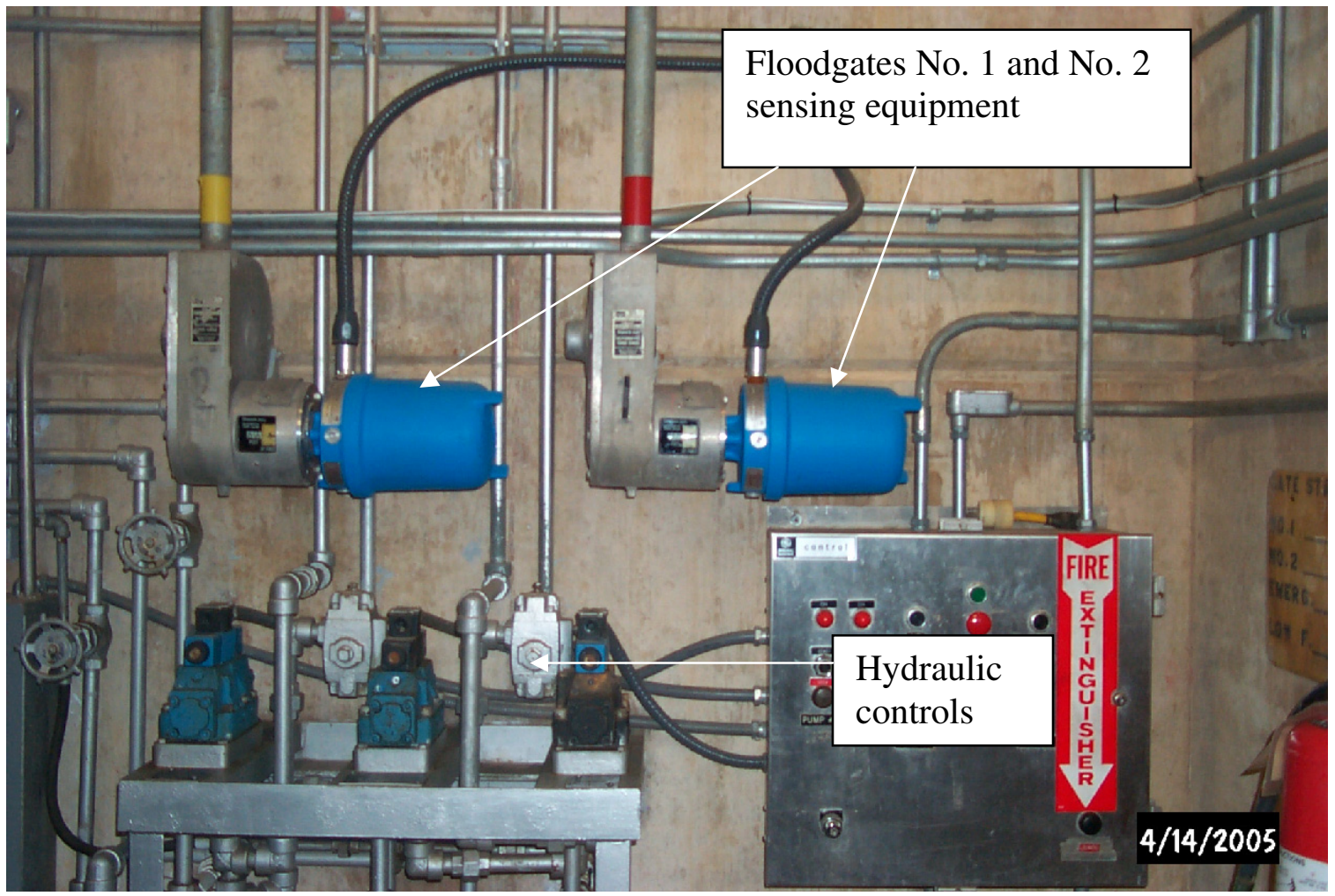

Figure 33. Gate-sensing equipment at Granger Lake. 


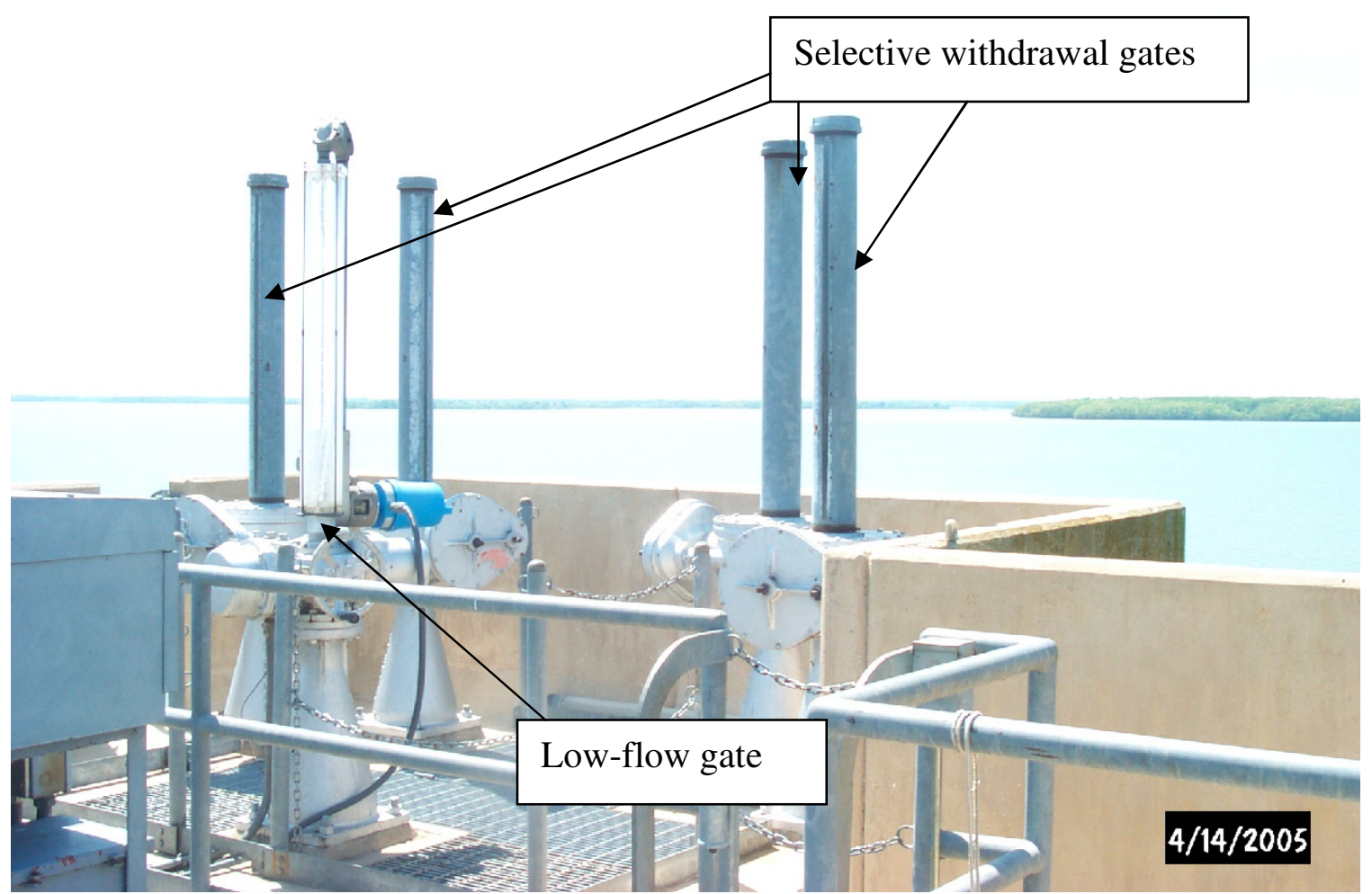

Figure 34. Low-flow gate and selective withdrawal gates at Granger Lake. 


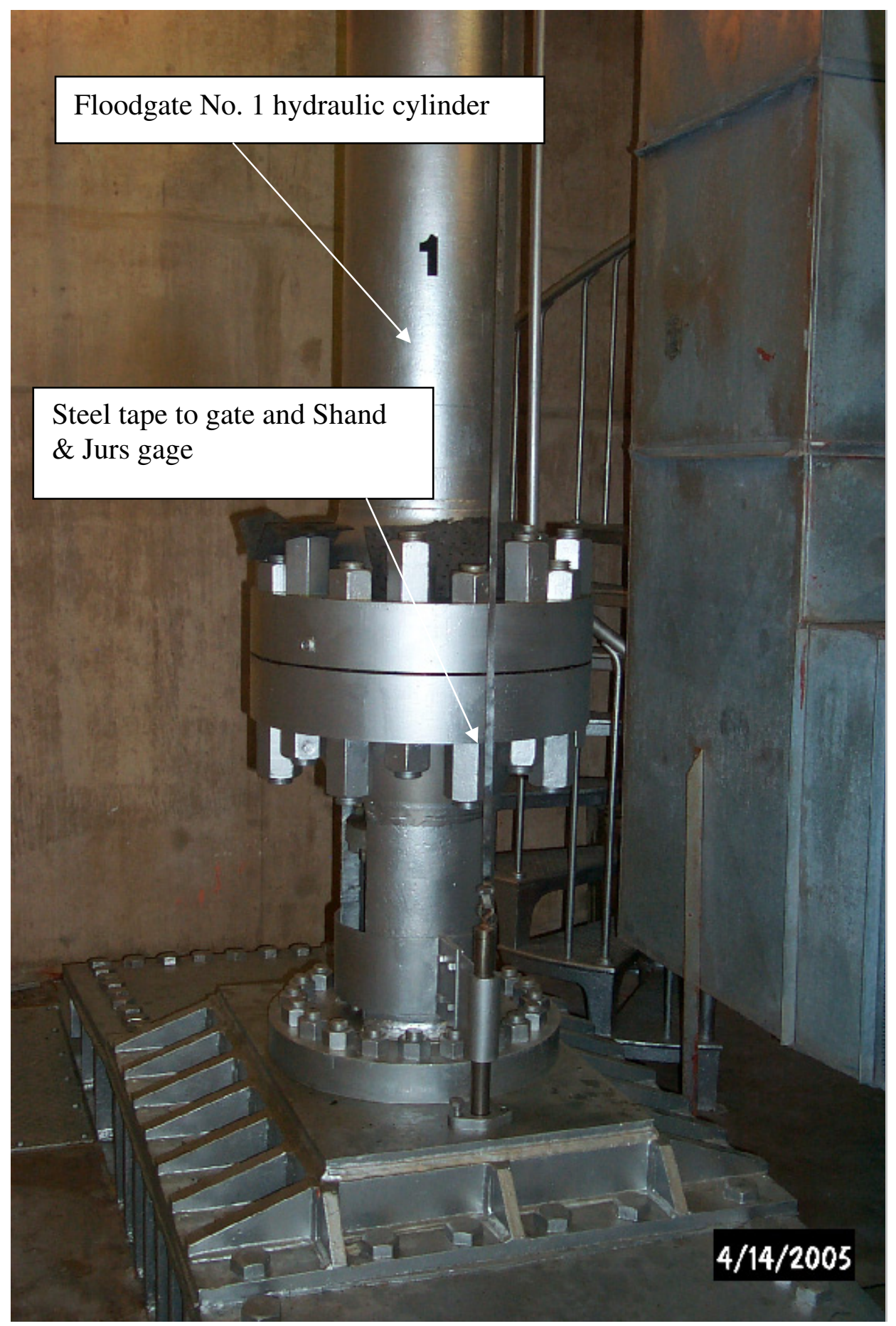

Figure 35. Hydraulic cylinder at Granger Lake. 


\section{Granger Lake Sutron 8210 Setup File (GRANGER.SET)}

; 8210/8200 ASCII setup file, can be converted back to a .SET file with WSETMGR.EXE

;

; MAIN SETUP

;

Setup_Version $=$ V6X

Unit_ID=GRANGER

Measurement_Interval=00:30:00

Sampling_Interval=00:00:00

Measurement_Time $=00: 00: 00$

Sampling_Time $=00: 00: 00$

Switched_Power_Time=00:00:00

Samples_to_Average $=0$

Measurements_per_Log=1

Switched_Power_Mode $=\mathrm{ON}$

Recording $=\mathrm{ON}$

Basic_Run_Interval $=00: 00: 00$

Basic_Run_Time $=00: 00: 00$

Password=

Number_Resets $=4$

Log_Size $=124928$

Rom_Checksum=57134

;

; EEROM SETUP

;

Serial_Port_Mode=USER

User_Baud_Rate $=9600$

Radio_Baud_Rate $=1200$

Com_Baud_Rate $=9600$

Transfer_Baud_Rate $=9600$

SDI_Baud_Rate $=1200$

Enter_Key_Reqd=OFF

Log_Dump_Mode=ALL-BIN

User_Time_Limit $=600$

Power_Delay $=1$

Analog_Delay $=5$

Pressure_Delay $=5$

Auto_Startup_Keys=

Time_Format=NORMAL

Date_Format=MDY

Term_Xmit_Delay $=0$

Basic_Size $=1$

Amp_Gain=1.0

;

; PROTOCOL SETUP

Master_Name=

Carrier_Delay=7

Com_Port_Mode=

Reply_Delay $=0$

Ack_Delay $=100$ 


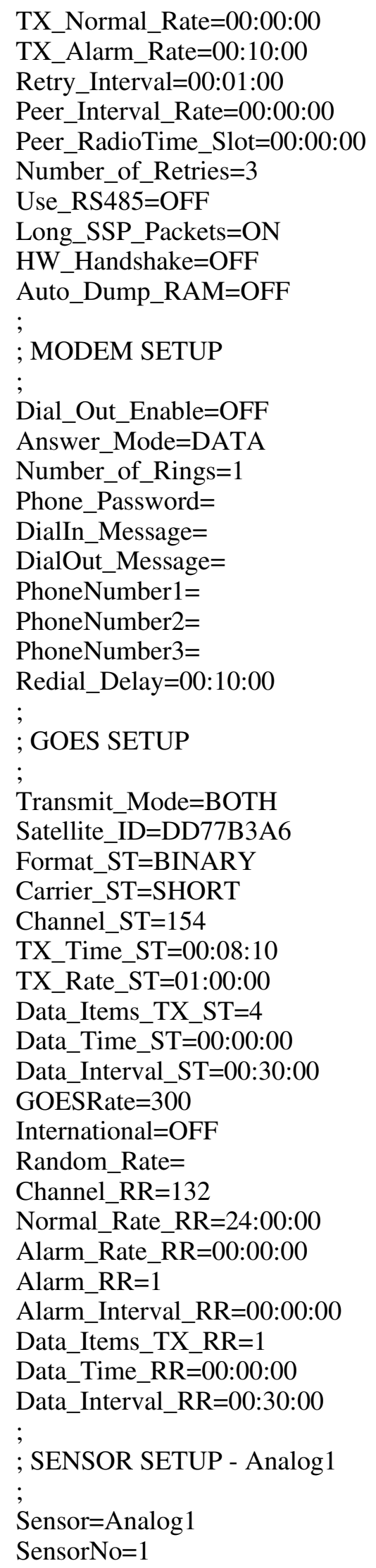




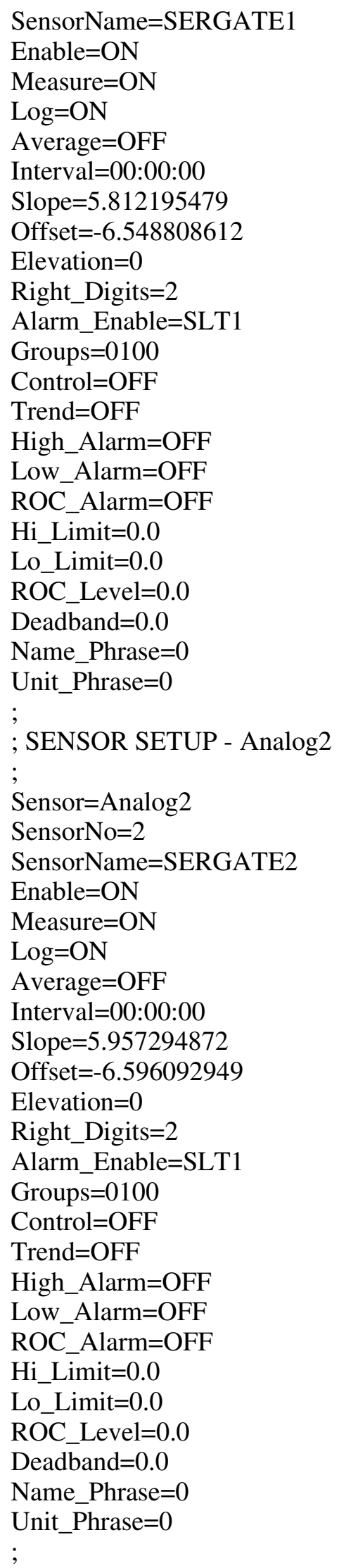




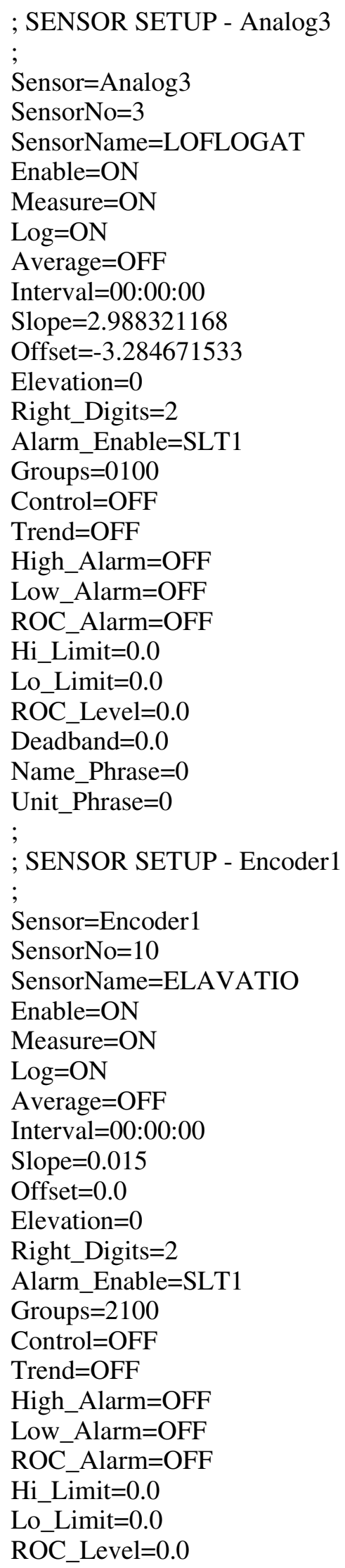




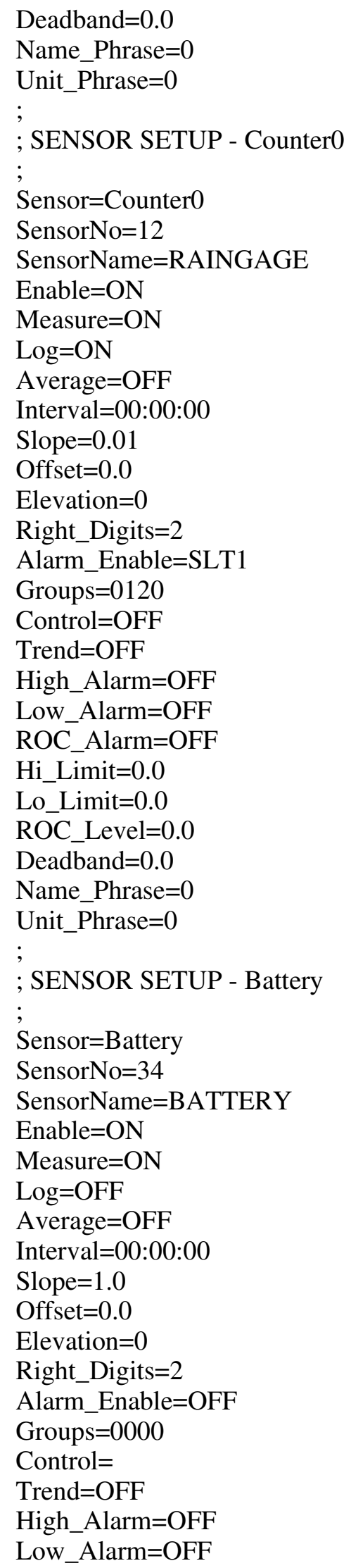


ROC_Alarm $=\mathrm{OFF}$

Hi_Limit $=0.0$

Lo_Limit $=0.0$

ROC_Level $=0.0$

Deadband $=0.0$

Name_Phrase $=0$

Unit_Phrase $=0$ 


\section{Grapevine Lake Near Grapevine, Tex.}

\section{Location}

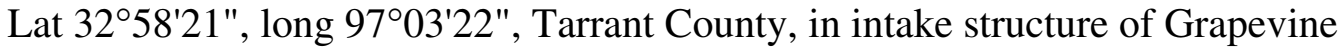
Dam on Denton Creek, $2.7 \mathrm{mi}$ northeast of Grapevine, $4.3 \mathrm{mi}$ upstream from bridge on SH 121, and 11.7 mi upstream from mouth.

\section{Road Log}

From USGS Texas WSC-Fort Worth, take I-20 east to I-820. Take I-820 north to SH 121. Travel north on SH 121 to Bass Pro Dr., exit on Bass Pro Dr., and travel north (turn left) $0.6 \mathrm{mi}$ to SH 26. Travel west (turn left) on SH 26 for 0.6 mi to Fairway Dr., turn right onto Fairway Dr. The USACE office is on the right. Continue on Fairway Dr. past the office to get to the intake structure. Fairway Dr. crosses the top of the dam and is open to the public.

\section{Access}

Before visiting the site, call the Grapevine Dam USACE office at 817-481-4541 to let them know you will be servicing the site and to get access to the intake structure. The USACE office has a key to the gate off Fairway Dr. and the keys to the main door of the intake structure.

\section{Equipment Description}

Refer to table 7, "Grapevine Lake equipment inventory," for a complete list of equipment and to figures 36-40 for equipment wiring diagrams and photographs of equipment. Two main floodgates (Floodgates No. 1 and No. 2) are raised and lowered by electric motors and cables. Floodgate No. 1 is on the right side of the intake structure (facing upstream) and Floodgate No. 2 is on the left.

Each gate has a Celesco VLS9600 series cable-extension transducer and a Schmitz Engineering 24MT series position transmitter, or shaft encoder that measures the position of the gates. As a gate moves up and down, a stainless steel cable attached to the top of the gate is wound and unwound around a precisely machined, constant-diameter cylindrical spool. The cable is wrapped around the cylinder with a traversing cable guide to create a single layer of wire, thereby preventing inaccuracies associated with a changing spool diameter. The spool is attached to a shaft coupled with a shaft encoder that measures the amount of linear displacement. The VLS9600 cable-extension position transducer is actually a PT9600 instrument with a VLS (velocity limiting system) attached as an option. The VLS limits cable retraction rates to a safe speed to prevent damage caused by accidental free release. The amount of cable on the spool is 1,500 in., or $125 \mathrm{ft}$.

For both gates, dials to indicate gate position are located on the spools on which the cables are wound and unwound to raise and lower the gates. Sometimes the dials do not function properly. They can malfunction (read incorrectly) because the dials turn as the spools turn and not necessarily when the gates are moving. The gates do not begin to move until all slack is out of the cables; however, the dials move as slack is taken out of 
the cables. Be careful using the dials as reference for the two floodgates. The Celesco units and the Schmitz shaft encoders are assumed to measure the true position of the gates because the wires attached to the top of the gates do not move until the gates themselves move.

Two low-flow gates are on the lower deck of the intake structure; they will be referred to here as Low-Flow Gates No. 1 and No. 2 to be consistent with naming conventions at other dams. Low-Flow Gate No. 1 is on the right side of the intake structure (facing upstream) and Low-Flow Gate No. 2 is on the left. Low-Flow Gate No. 1 has a Handar quadrature shaft encoder that is wired to a Water Log SDI12 Quadrature Model H-411 that converts the signal to SDI12. The Low-Flow Gate No. 2 shaft encoder is a Sutron SDI12 sensor. The shaft encoders send a signal to the Sutron datalogger to indicate gate position. A rod is attached to the gate, and as the gate is raised and lowered the rod travels up and down. A pointer is attached to the rod that also moves up and down and indicates gate position by pointing to a ruler mounted alongside the rod. The pointer and the ruler are assumed to display the true position of the gate; the shaft encoder is set to this reference. A metal tape attached to the top of the rod goes over a pulley attached to the shaft encoder. As the pulley turns, the shaft encoder wheel turns with it and ultimately indicates the amount of linear displacement. Unlike the electric motors and cables that open and close the service gates, the low-flow gates are raised and lowered with electric valve operators.

The Sutron 8210 datalogger is powered by a 12-VDC battery, which is charged by an automatic sealed lead-acid battery charger connected to a $120-\mathrm{VAC}$ wall outlet. The position transmitters are powered by the Sutron 8210 datalogger through the 12 VDC port (labeled +) on the terminal strip of the Sutron 8210.

The setup file (GPVT2.SET) is stored on the RAM card that is kept inside the Sutron equipment box. A hard copy of the setup file and the basic program file is also kept in the station folder.

The positions of Floodgates No. 1 and No. 2 and Low-Flow Gates No. 1 and No. 2 are transmitted by satellite and posted on the USACE Web site (http://www.swfwc.usace.army.mil) under Daily Reports/Gate Sensor Report. The USACE reports hourly data; however, the Sutron datalogger measures and records the gate position for the four gates every 15 minutes.

Floodgates No. 1 and No. 2 are FG1 and FG2, respectively, and Low-flow Gates No. 1 and No. 2 are LOW3 and LOW4, respectively, in the Sutron setup file.

\section{Operation and Maintenance}

Operation and maintenance information for the equipment at Grapevine Dam includes descriptions of different procedures required to maintain equipment such as routine inspections, recalibration of Floodgates No. 1 and No. 2, recalibration of LowFlow Gates No. 1 and No. 2, and annual inspections. The purpose of a site visit and the actions taken should be documented in the logbook kept near the datalogger. Include the date, time, actions, and personnel conducting the site visit in the logbook. This section lists some of the potential problems that might occur with the equipment in service and possible solutions to the problems. Refer to the Operations Manuals for the individual pieces of equipment when further detail is required. The information included here is basic operations and maintenance information. 
For each visit to the site, personnel should carry all of the necessary tools required to service the equipment. The tools required to perform all of the tasks listed include the following:

- Screwdrivers, flat and Phillips head

- Allen wrenches, 5/32- and 7/64-in.

- Crescent wrench, 10-in.

- Stepladder, 10-ft

- Electrical tape

- Digital multimeter

- Pliers

- Ruler

- Laptop computer capable of connecting (with RS-232 port and 9-pin cable) to Sutron 8210

- Sutron 8210 Operations Manual

- Battery load tester

- Spare battery

- Flashlight

- Silicone sealant

\section{Procedures during a routine inspection}

- Check the enclosure to the Sutron 8210 datalogger for damage and moisture. If moisture is entering the enclosure, seal any openings with silicone.

- Scroll through the VIEW DATA/LIVE READINGS menu and check that the datalogger is making measurements.

- Check the antennas (data and GPS) and make sure connections are secure and waterproofed. Replace electrical tape around connections if old and brittle.

- Check the battery voltage under the LIVE READINGS menu on the Sutron 8210.

- If voltage is low (less than $11.5 \mathrm{~V}$ ), test the battery with a load tester and make sure the voltage remains above the recommended voltage specific to the load tester being used. Replace battery as needed.

- Verify Floodgates No. 1 and No. 2 position sensors and transmitters are functioning properly by pulling down on the Celesco steel wire a known distance and checking the reading in the datalogger. Hold a ruler flush with the bottom of the Celesco unit. Pull the wire down $1 \mathrm{ft}$ and verify that the datalogger recorded a value $1 \mathrm{ft}$ less than the current reading. The datalogger and the Celesco units are too far apart for someone to pull down on the wire and view the readings on the datalogger. The datalogger records readings every 15 minutes, so this would have to be done just prior to the datalogger recording a new reading. If another person is available to call out the readings under LIVE READINGS on the datalogger then it would not be necessary to wait until the 15-minute mark. It also would not be necessary to wait until the 15-minute mark if the person servicing the site had about $40 \mathrm{ft}$ of 9-pin cable and a laptop with Sutron TS8210 software so that the live readings could be viewed on the laptop. If the actual amount of displacement and the measured amount do not agree, make a note of the difference. Make sure the difference is not caused by inaccuracies associated with trying to pull the wire down a known distance. According to the manufacturer, at $1 \mathrm{ft}$ of displacement 
the unit is accurate to within $0.0004 \mathrm{ft}$. Do not try to force agreement between the displaced amount and the measured amount by adjusting the slope or the offset in the Sutron 8210 setup. However, check that the slope is set properly to 1.0511 for both shaft encoders and adjust if set incorrectly (see "Procedures to Recalibrate Floodgates No. 1 and No. 2"). Check that the connections between the shaft encoders and the Celesco position sensors are good by making sure the Allen screws that connect the two are not loose. Open the cover on the position sensor where the wire enters the unit. Visually check that the wire appears to be winding up uniformly across the wheel and that no kinks are present. Do not try to remove the cylinder that holds the wire. If the wire is pulled down and the shaft encoder does not respond at all (no change in position), check that the SDI12 addresses are set correctly in the Sutron 8210 setup. Floodgates No. 1 and No. 2 should have addresses 3 and 4, respectively. If the slopes are set correctly, the connections and wire appear good, the shaft encoders are responding, and the SDI12 addresses are set correctly, then the shaft encoders or the Celesco position sensors need to be replaced or serviced. Try removing the shaft encoder first and testing it with another Celesco unit known to function properly to try to isolate the problem. If the shaft encoder is good, then the Celesco unit should probably be removed and serviced. This will have to be done during an annual inspection. Refer to the "Manufacturer Contact Information" section for address and phone number.

- Check that the Sutron 8210 is reading the same value (within $0.01 \mathrm{ft}$ ) as the pointer and ruler on Low-Flow Gates No. 1 and No. 2. If not, open the box with the shaft encoder and make sure the encoder tape has not come off the pulley. Check that the equipment box does not contain bee or wasp nests, or both, that interfere with rotation. If the tape is not off the pulley and the pulley appears to move freely, recalibrate the shaft encoder by following instructions under "Procedures to recalibrate Low-Flow Gates No. 1 and No. 2."

- Whenever a change is made to the setup file in the datalogger, download the new file to the RAM card kept at the site. To do this, insert the RAM card into the socket and turn on the 8210. Scroll down to the DUMP DATA menu. Press the right arrow once, then press the down arrow until WRITE CARD SETUP is displayed. Press the SET button and wait for the file to be transferred from the datalogger to the RAM card. To transfer the file from the RAM card to the datalogger, scroll down to the DUMP DATA menu. Press the right arrow once, then press the down arrow until READ CARD SETUP is displayed. Press the right arrow to access the setup file. Transfer the selected file to the datalogger by pressing the SET button.

- Before leaving the site, make sure the Sutron 8210 is reading ON \& TX under RECORDING.

\section{Procedures to recalibrate Floodgates No. 1 and No. 2}

- First make sure that the slope of the shaft encoders is set to 1.0511, as one revolution of the Celesco is 12.613 in. With the gates closed, set the instruments to read zero by adjusting the offset of the Schmitz Engineering shaft encoders.

- To change the offset or the slope, turn on the Sutron 8210 and press the down arrow to SYSTEM SETUP. Press the right arrow once and the down arrow twice to CONFIG SENSORS. Then press the right arrow once and the down arrow to 
select either FG1 or FG2. With the correct shaft encoder selected, press the right arrow once and then the down arrow to slope and offset. Press the SET button once when either slope or offset are highlighted. Change the value using the arrow buttons. Right and left arrow buttons move from one digit to the next. Up and down arrow buttons increase or decrease the value, respectively. When finished, press the SET button to save the new value. Check LIVE READINGS or the digital display to see the new measured value.

- Record changes to the slope or the offset in the logbook and save the new setup file to the RAM card.

\section{Procedures to recalibrate Low-Flow Gates No. 1 and No. 2}

- Lower the selected gate so that it is closed and the rod and pointer read zero. Set the Sutron shaft encoder to read zero by adjusting the offset in the datalogger setup file. First check that the slope values for the Handar (Low-Flow Gate No. 1) and the Sutron (Low-Flow Gate No. 2) shaft encoders are set to 1.00.

- To change the offset or the slope, follow the same instructions as those given for changing the offset or the slope to Floodgates No. 1 and No. 2 except select LOW3 and LOW4 instead of FG1 or FG2.

- Open Low-Flow Gate No. 1 or No. 2 to its previous position (if open) and verify that the Sutron and the rod and pointer read the same.

- Record changes to the slope or the offset in the logbook and save the new setup file to the RAM card.

\section{Procedures during an annual inspection}

- During an inspection the emergency gates are lowered, and the floodgates are raised all the way up into the intake structure where they are cleaned and inspected. As the gates are raised, check and clean the wire as it winds up into the Celesco position sensor. Check the wire for worn areas and clean debris off the wire. If the wire appears substantially damaged do not try to replace the wire. Send the unit to Celesco for service. Refer to the "Manufacturer Contact Information" section for address and phone number.

- When the gates are lowered and closed after being serviced, check that the shaft encoders and datalogger measure zero. If not, follow the instructions on how to recalibrate the instruments.

- After the inspection, follow all of the procedures for a routine inspection. 
Table 7. Grapevine Lake equipment inventory.

[See table of contents for abbreviated units; --, not available or not applicable]

\begin{tabular}{|c|c|c|c|c|}
\hline $\begin{array}{c}\text { Item } \\
\text { no. }\end{array}$ & Item description & Manufacturer & Model no. & Remarks \\
\hline 1. & Floodgate No. 1 position sensor & Celesco & VLS9600-1500-114-SCH-24MTF & $\begin{array}{l}\text { Gate is FG1 in Sutron setup and equipment is } \\
\text { labeled with numeral } 1\end{array}$ \\
\hline 2. & Floodgate No. 1 position transmitter & $\begin{array}{l}\text { Schmitz } \\
\text { Engineering } \\
\end{array}$ & 24MT-256-4096-AX-SDI-12-F-CR6 & Shaft encoder with SDI12 address 3 \\
\hline 3. & Wire for position transmitter No. 1 & -- & -- & $\begin{array}{l}24 \text { AWG with } 3 \text { wires going from transmitter } \\
\text { to junction box less than } 1 \mathrm{ft} \text { away }\end{array}$ \\
\hline 4. & $\begin{array}{l}\text { Wire from junction box at No. } 1 \text { to } \\
\text { terminal strip A }\end{array}$ & -- & -- & $\begin{array}{l}\text { Approximately } 50 \mathrm{ft} \text { of } 18 \mathrm{AWG} / 5 \text { wires but } \\
\text { only } 3 \text { wires are needed }\end{array}$ \\
\hline 5. & Floodgate No. 2 position sensor & Celesco & VLS9600-1500-114-SCH-24MTF & $\begin{array}{l}\text { Gate is FG2 in Sutron setup and equipment is } \\
\text { labeled with numeral } 2\end{array}$ \\
\hline 6. & Floodgate No. 2 position transmitter & \begin{tabular}{|l|} 
Schmitz \\
Engineering
\end{tabular} & 24MT-256-4096-AX-SDI-12-F-CR6 & Shaft encoder with SDI12 address 4 \\
\hline 7. & Wire for position transmitter No. 2 & -- & -- & $\begin{array}{l}24 \text { AWG with } 3 \text { wires going from transmitter } \\
\text { to junction box less than } 1 \mathrm{ft} \text { away }\end{array}$ \\
\hline 8. & $\begin{array}{l}\text { Wire from junction box at No. } 2 \text { to } \\
\text { terminal strip A }\end{array}$ & -- & -- & $\begin{array}{l}\text { Approximately } 30 \mathrm{ft} \text { of } 22 \mathrm{AWG} / 4 \text { wires but } \\
\text { only } 3 \text { wires are needed }\end{array}$ \\
\hline 9. & $\begin{array}{l}\text { Low-Flow Gate No. } 1 \text { position } \\
\text { sensor }\end{array}$ & Handar & $436 \mathrm{~A}$ & $\begin{array}{l}\text { Gate is LOW3 in Sutron setup and has SDI12 } \\
\text { address } 1\end{array}$ \\
\hline 10. & $\begin{array}{l}\text { Wire from Low-Flow Gate No. } 1 \\
\text { position sensor to terminal strip B }\end{array}$ & -- & -- & Approximately $95 \mathrm{ft}$ of $22 \mathrm{AWG} / 4$ wires \\
\hline 11. & $\begin{array}{l}\text { Low-Flow Gate No. } 2 \text { position } \\
\text { sensor }\end{array}$ & Sutron & $56-0540$ & $\begin{array}{l}\text { Gate is LOW4 in Sutron setup and has SDI12 } \\
\text { address } 2\end{array}$ \\
\hline 12. & $\begin{array}{l}\text { Wire from Low-Flow Gate No. } 2 \\
\text { position sensor to terminal strip A }\end{array}$ & -- & -- & Approximately $70 \mathrm{ft}$ of $22 \mathrm{AWG} / 3$ wires \\
\hline 13. & Stage shaft encoder & Handar & $436 \mathrm{~A}$ & Named LAKE STAGE in Sutron setup \\
\hline 14. & Rain gage & Design Analysis & $\mathrm{H}-340$ & $-{ }^{2-}$ \\
\hline 15. & Datalogger & Sutron & 8210 & -- \\
\hline 16. & Data recorder sensor & Design Analysis & Water Log SDI-12 Quadrature H-411 & $\begin{array}{l}\text { Converts analog output from Handar Low- } \\
\text { Flow Gate No. } 1 \text { to SDI12 }\end{array}$ \\
\hline 17. & Battery & Power Sonic & PS-12550U & $12-\mathrm{V}, 55.0-\mathrm{A}-\mathrm{h}$ battery for Sutron 8210 \\
\hline 18. & Battery charger & Power Sonic & PSC-12800A & $12-\mathrm{V}, 800-\mathrm{mA}$ \\
\hline 19. & Antenna & -- & -- & Mounted on upstream side of intake structure \\
\hline 20. & Antenna cable & Manhattan & M4206 RG 8/U & 30-ft cable from Sutron 8210 to antenna \\
\hline 21. & Data transmitter & Sutron & Satlink & -- \\
\hline 22. & GPS antenna & Trimble & Miniature 5V & $\begin{array}{l}\text { Magnetic mount on railing outside of entrance } \\
\text { to intake structure }\end{array}$ \\
\hline 23. & GPS antenna cable & Trimble & -- & Cable comes with antenna \\
\hline
\end{tabular}




\section{Job Hazard Analysis}

Required protective clothing, safety equipment, and supplies: Personal flotation device (PFD), reflective vest, gloves, steel-toed shoes, waders, cell phone, first aid kit, fire extinguisher, rotating or strobe type emergency lights, drinking water.

\begin{tabular}{|c|c|c|}
\hline $\begin{array}{l}\text { Sequence of basic } \\
\text { job steps }\end{array}$ & $\begin{array}{l}\text { Potential } \\
\text { accident or hazard }\end{array}$ & Recommended safe job procedures \\
\hline $\begin{array}{l}\text { Upon job } \\
\text { assignment }\end{array}$ & $\begin{array}{l}\text { Water-related accident or } \\
\text { injury }\end{array}$ & $\begin{array}{l}\text { Employees working in and around water must receive } \\
\text { training specified in WRD Memo 2000.10, "Policy for } \\
\text { safety training associated with over-water activities." }\end{array}$ \\
\hline $\begin{array}{l}\text { Loading and } \\
\text { unloading } \\
\text { equipment }\end{array}$ & $\begin{array}{l}\text { Pinched fingers, mashed } \\
\text { toes, or strained back }\end{array}$ & $\begin{array}{l}\text { Be aware of hand placement. Wear protective gloves and } \\
\text { steel-toed shoes. Use proper lifting techniques. Lift with } \\
\text { legs. Use extra caution lifting heavy sounding weights. }\end{array}$ \\
\hline $\begin{array}{l}\text { Driving to and } \\
\text { returning from work } \\
\text { site }\end{array}$ & $\begin{array}{l}\text { Traffic accidents, vehicle } \\
\text { flooding, or drowning }\end{array}$ & $\begin{array}{l}\text { Drivers of USGS vehicles must have Drivers Safety } \\
\text { Training (SM 445-2-H, chap. 16). Be alert to traffic in } \\
\text { area, obey all traffic laws, and reduce speed when weather } \\
\text { conditions are bad. Do not drive across flooded highways } \\
\text { unless water depth and bridge conditions are known to be } \\
\text { safe. }\end{array}$ \\
\hline Parking vehicle & $\begin{array}{l}\text { Personal and vehicle } \\
\text { safety when exiting } \\
\text { vehicle in traffic; bank } \\
\text { collapse or bridge failure }\end{array}$ & $\begin{array}{l}\text { Use rotating or strobe emergency lights, follow site } \\
\text { traffic-control plan, wear DOT Type III reflective vest } \\
\text { when working in or near roadway. Park away from stream } \\
\text { at a safe distance from banks. }\end{array}$ \\
\hline $\begin{array}{l}\text { Set up traffic- } \\
\text { control equipment }\end{array}$ & $\begin{array}{l}\text { Personal and public } \\
\text { safety }\end{array}$ & $\begin{array}{l}\text { Employees working in or near roadways must have Work } \\
\text { Zone Traffic-Control Safety Training. Remain alert to } \\
\text { traffic conditions. }\end{array}$ \\
\hline $\begin{array}{l}\text { Working at field } \\
\text { site }\end{array}$ & Drowning & $\begin{array}{l}\text { Employees are required to wear a PFD when working in, } \\
\text { on, or over any body of water. There are no exemptions } \\
\text { for employees in the Texas WSC. PFDs will be } \\
\text { international orange in color and equipped with reflective } \\
\text { tape in accordance with } 46 \text { CFR } 25.25-15 \text {. Self-inflating } \\
\text { PFDs are not to be worn by employees who have not had } \\
\text { In-Water Safety Training. }\end{array}$ \\
\hline $\begin{array}{l}\text { Working at field } \\
\text { site }\end{array}$ & Trips, slips, and falls & $\begin{array}{l}\text { Follow path clear of obstructions and with minimal slope; } \\
\text { avoid slippery surfaces. Walk cautiously on steep slopes } \\
\text { or paths with loose material. Use appropriate footwear for } \\
\text { the terrain and conditions. Follow the safest, not the } \\
\text { fastest path! }\end{array}$ \\
\hline $\begin{array}{l}\text { Working at field } \\
\text { site }\end{array}$ & $\begin{array}{l}\text { Dehydration, heat } \\
\text { exhaustion, heat stroke, } \\
\text { or sunburn }\end{array}$ & $\begin{array}{l}\text { Drink plenty of water or electrolyte drink. Wear } \\
\text { appropriate clothing. Take occasional breaks and watch } \\
\text { for symptoms of heat exhaustion. Use sun block. }\end{array}$ \\
\hline $\begin{array}{l}\text { Working at field } \\
\text { site }\end{array}$ & Hypothermia or frostbite & $\begin{array}{l}\text { Wear foul-weather gear during winter months. Keep } \\
\text { clothing dry. }\end{array}$ \\
\hline $\begin{array}{l}\text { Working at field } \\
\text { site }\end{array}$ & Snake bites & $\begin{array}{l}\text { Wear appropriate foot and leg protection. Watch path } \\
\text { ahead. Keep area around gage clear of brush. If bitten, } \\
\text { seek immediate medical help. }\end{array}$ \\
\hline
\end{tabular}




\begin{tabular}{|l|l|l|}
\hline $\begin{array}{l}\text { Working at field } \\
\text { site }\end{array}$ & Poisonous plants & $\begin{array}{l}\text { Know how to identify poisonous plants. Wear protective } \\
\text { clothing. Wash and flush exposed areas immediately with } \\
\text { cold water. Wash with degreasing type soap and flush } \\
\text { from skin. Seek medical attention for severe reactions. }\end{array}$ \\
\hline Entering gage house & $\begin{array}{l}\text { Infectious disease or } \\
\text { airborne pollutants; risk } \\
\text { of hantavirus exposure }\end{array}$ & $\begin{array}{l}\text { Watch for bat or rodent nests and droppings. If nest or } \\
\text { droppings are present, do not disturb dust. Gage should be } \\
\text { periodically cleaned to minimize risk of exposure. See } \\
\text { WRD memo dated 10/28/97, "Preventing hantavirus } \\
\text { disease," and OP memo dated 01/94, "Instructions for } \\
\text { preventing hantavirus disease." }\end{array}$ \\
\hline Entering gage house & Insect or snake bite & $\begin{array}{l}\text { Inspect in and around shelter for harmful insects. Use } \\
\text { wasp or insect spray. Inspect in and around shelter for } \\
\text { snakes prior to entry. }\end{array}$ \\
\hline
\end{tabular}

\section{Site-Specific Job Hazards}

The items listed are safety issues specific to this site that deserve special emphasis.

- Be careful removing or installing the Celesco position transmitters or the Schmitz shaft encoders on Floodgates No. 1 and No. 2. The gaps between the spools holding the cable that raises and lowers the gates are a fall hazard.

- Be careful descending the spiral staircase to the lower deck of the intake structure to service or check the low-flow gates.

- When servicing or checking the shaft encoders on Low-Flow Gates No. 1 and No. 2, use a stepladder (not an extension ladder) about $10 \mathrm{ft}$ tall. The shaft encoders are about $12 \mathrm{ft}$ from the floor of the lower deck. Be careful opening the equipment box because bee or wasp nests in the box are common. 
Figure 36. Grapevine Lake Sutron 8210 wiring panel
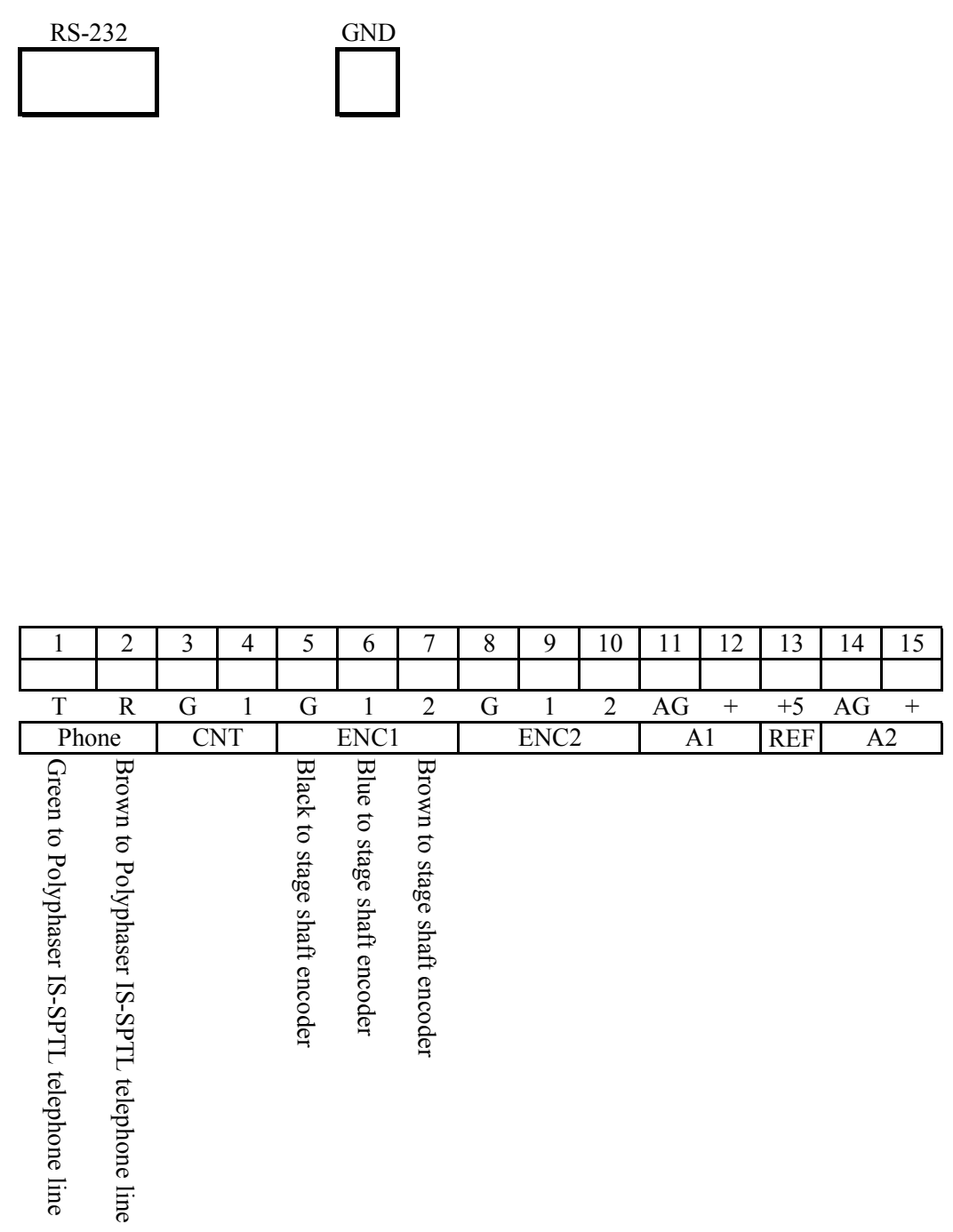

Note: FG1, Floodgate No. 1.

FG2, Floodgate No. 2.

Low-Flow Gates No. 1 and No. 2 are LOW3 and LOW4 in Sutron setup.

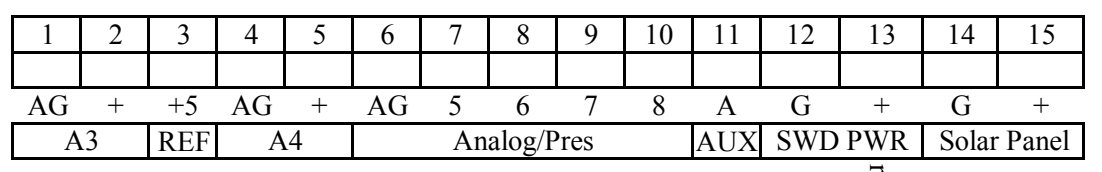

Goes to terminal strip A but ultimately to

FG1, FG2, Low-Flow Gate No. 1, Low-Flow Gate No. 2 , and rain gage.

\begin{tabular}{|c|c|c|c|c|c|c|c|c|c|c|c|c|c|c|}
\hline \multicolumn{2}{|c|}{ Ext Batt } & \multicolumn{2}{|c|}{ RS485 } & \multicolumn{3}{|c|}{ SDI-12 } & \multicolumn{3}{|c|}{ SDI-12 } & \multicolumn{5}{|c|}{ Digital Output } \\
\hline $\bar{G}$ & + & $\overline{\mathrm{A}}$ & $\bar{B}$ & $\overline{\mathrm{G}}$ & + & $\bar{D}$ & $\overline{\mathrm{G}}$ & + & $\bar{D}$ & 1 & 2 & 3 & 4 & 5 \\
\hline$\overline{1}$ & 2 & 3 & 4 & 5 & 6 & 7 & 8 & 9 & $\overline{10}$ & 11 & 12 & 13 & 14 & 15 \\
\hline
\end{tabular}

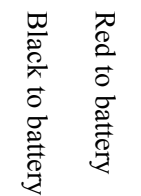

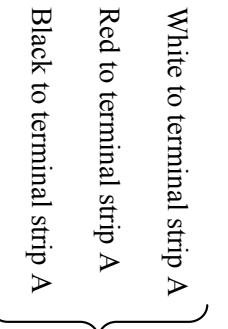

$\stackrel{\overrightarrow{0}}{\circ}$

$\frac{n}{\pi}$ 
Figure 37. Grapevine Lake equipment wiring diagram.
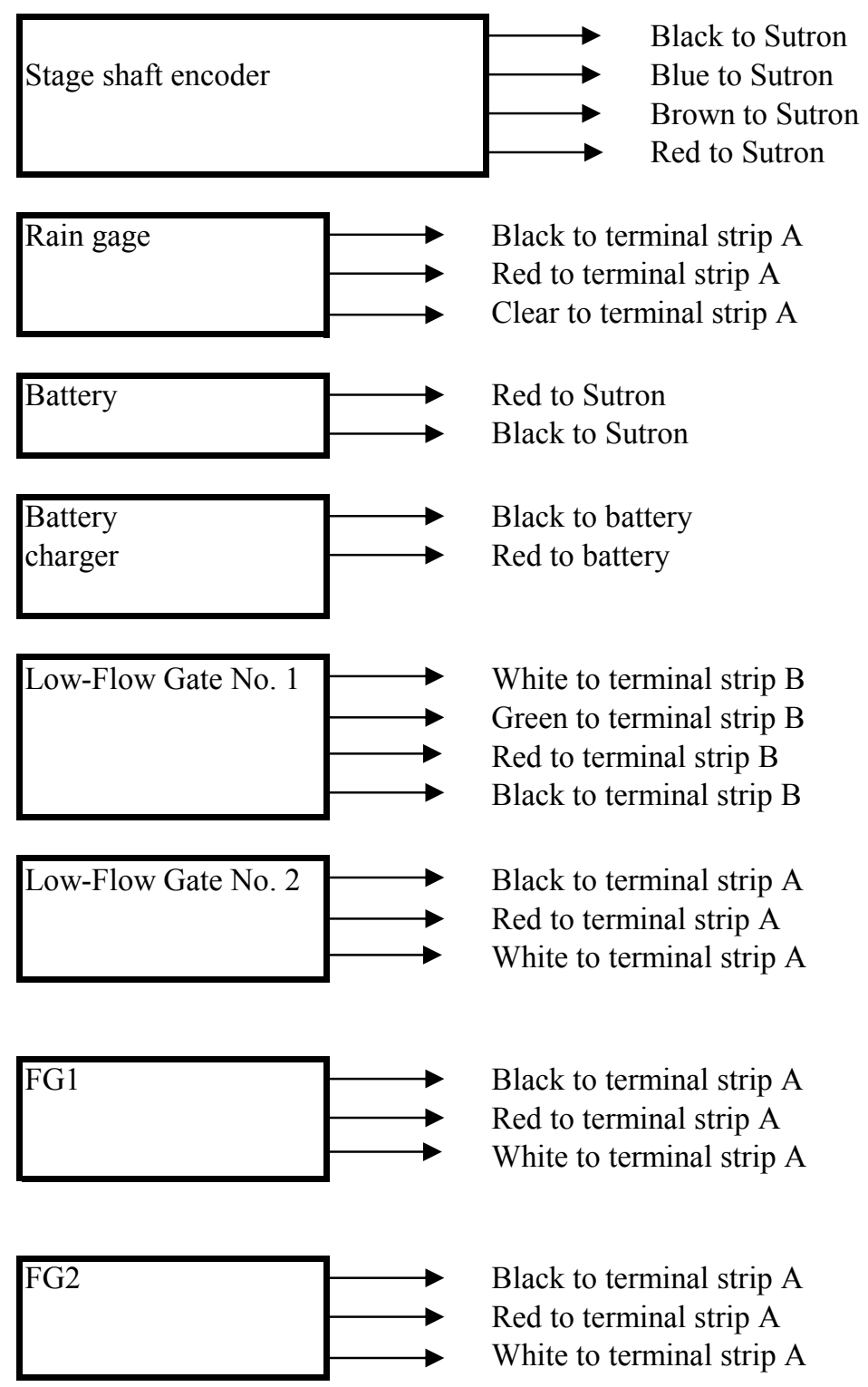

Red from terminal strip B White from terminal strip B Black from terminal strip B Black from terminal strip B

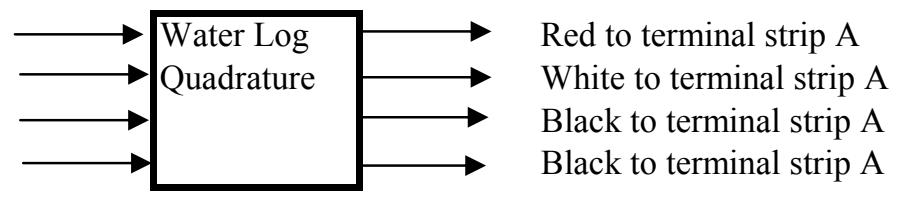

Note:

Low-Flow Gates No. 1 and No. 2 are LOW3 and LOW4 in Sutron setup.

FG1, Floodgate No. 1.

FG2, Floodgate No. 2. 
Figure 37. Grapevine Lake equipment wiring diagram--Continued

\section{Terminal strip A}

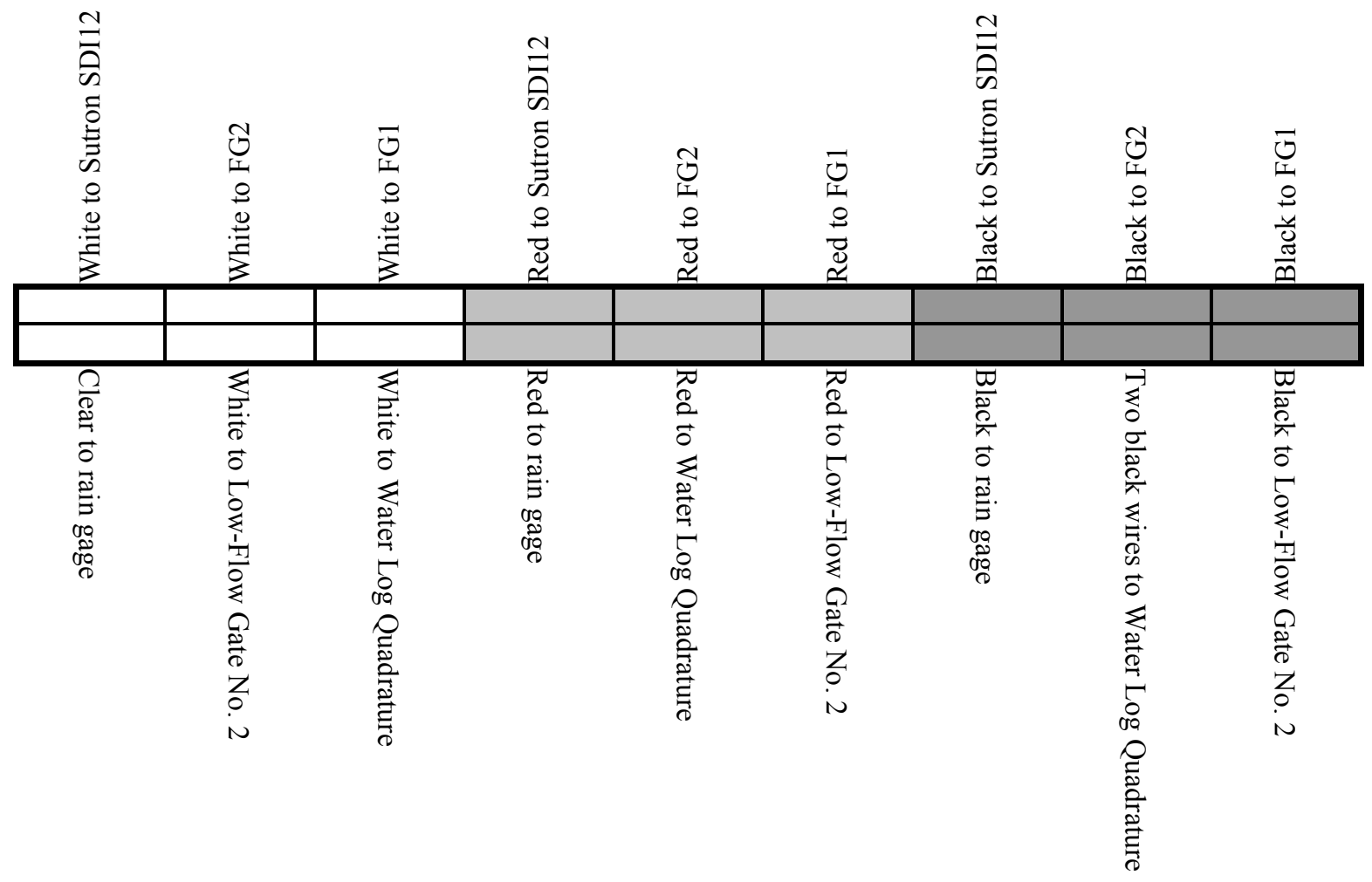

\section{Terminal strip B}

Red from Low-Flow Gate No. 1 Green from Low-Flow Gate No. 1 White from Low-Flow Gate No. Black from Low-Flow Gate No.

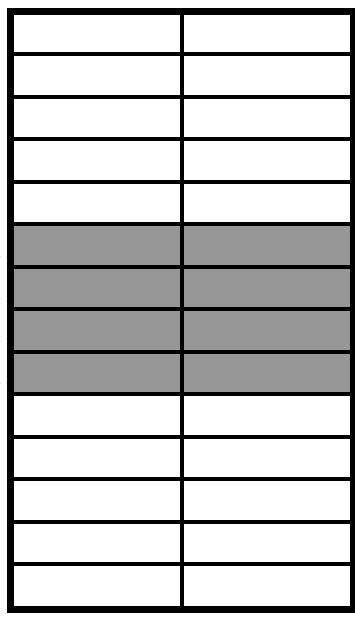

Red to Water Log Quadrature White to Water Log Quadrature Black to Water Log Quadrature Black to Water Log Quadrature

Note: $\quad$ FG2, Floodgate No. 2.

FG1, Floodgate No. 1.

Low-Flow Gates No. 1 and No. 2 are LOW3 and LOW4 in Sutron setup.

Similarly shaded cells are connected with jumpers. 


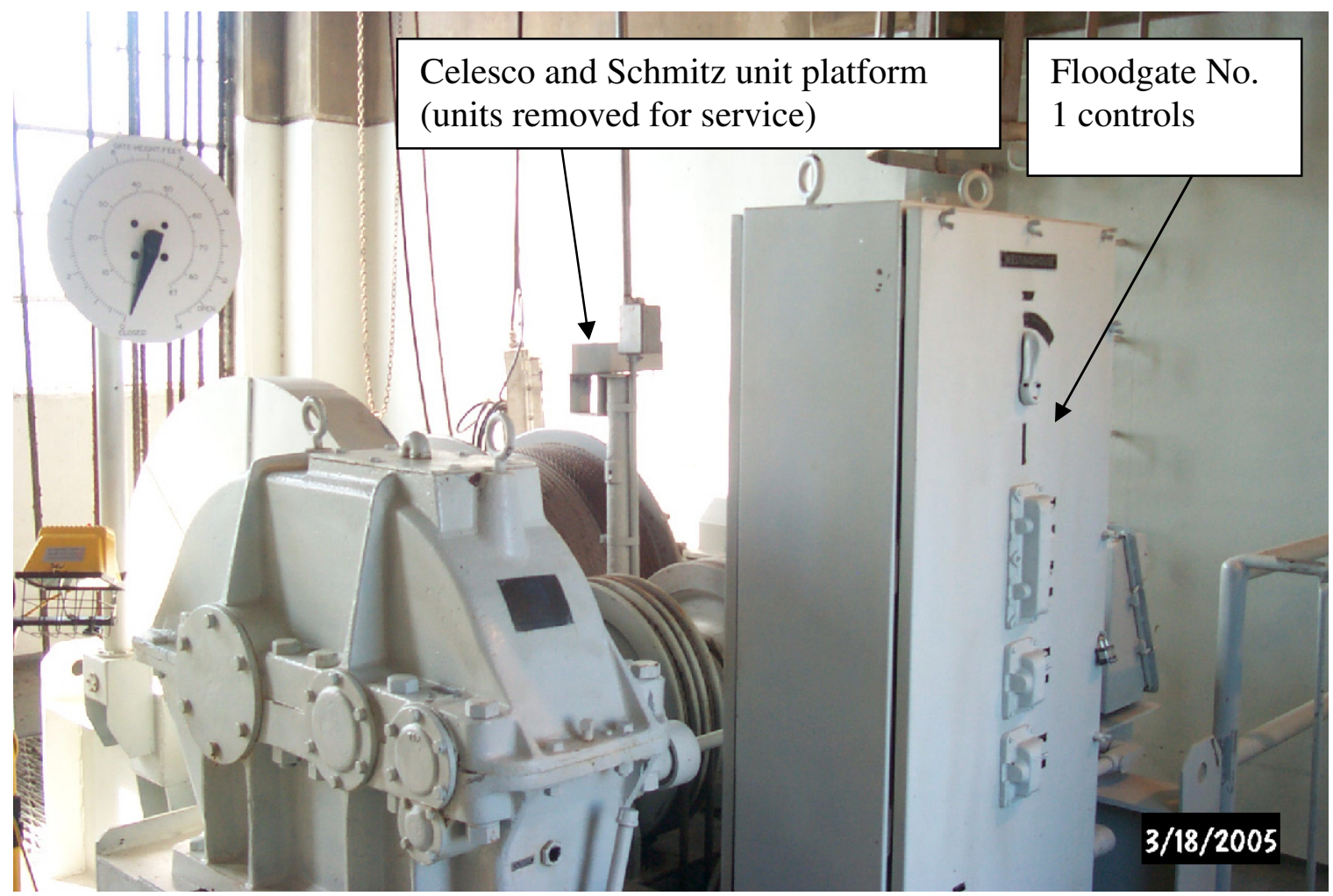

Figure 38. Gate-sensing equipment at Grapevine Lake.

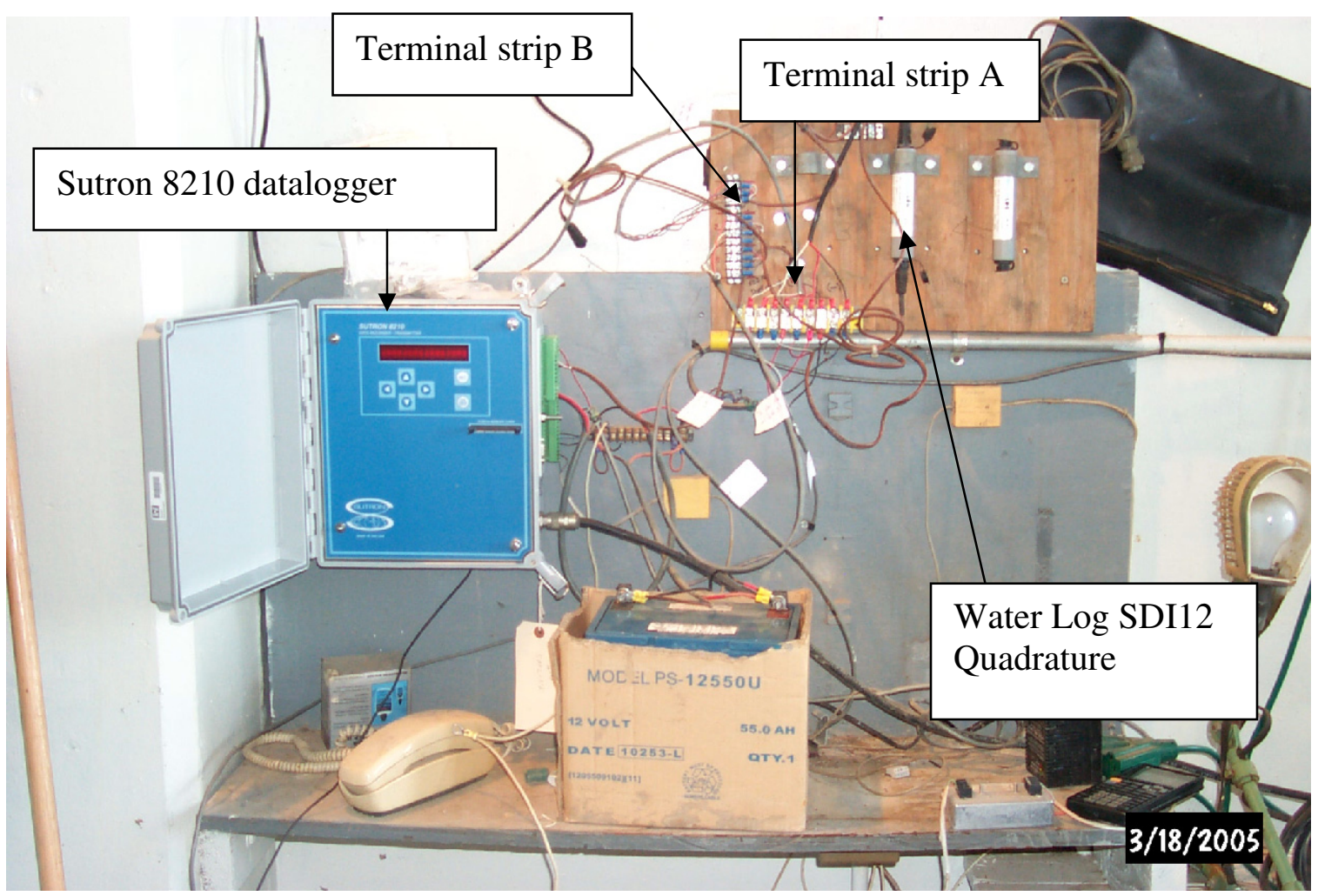

Figure 39. Sutron 8210 datalogger and wiring layout for Grapevine Lake. 


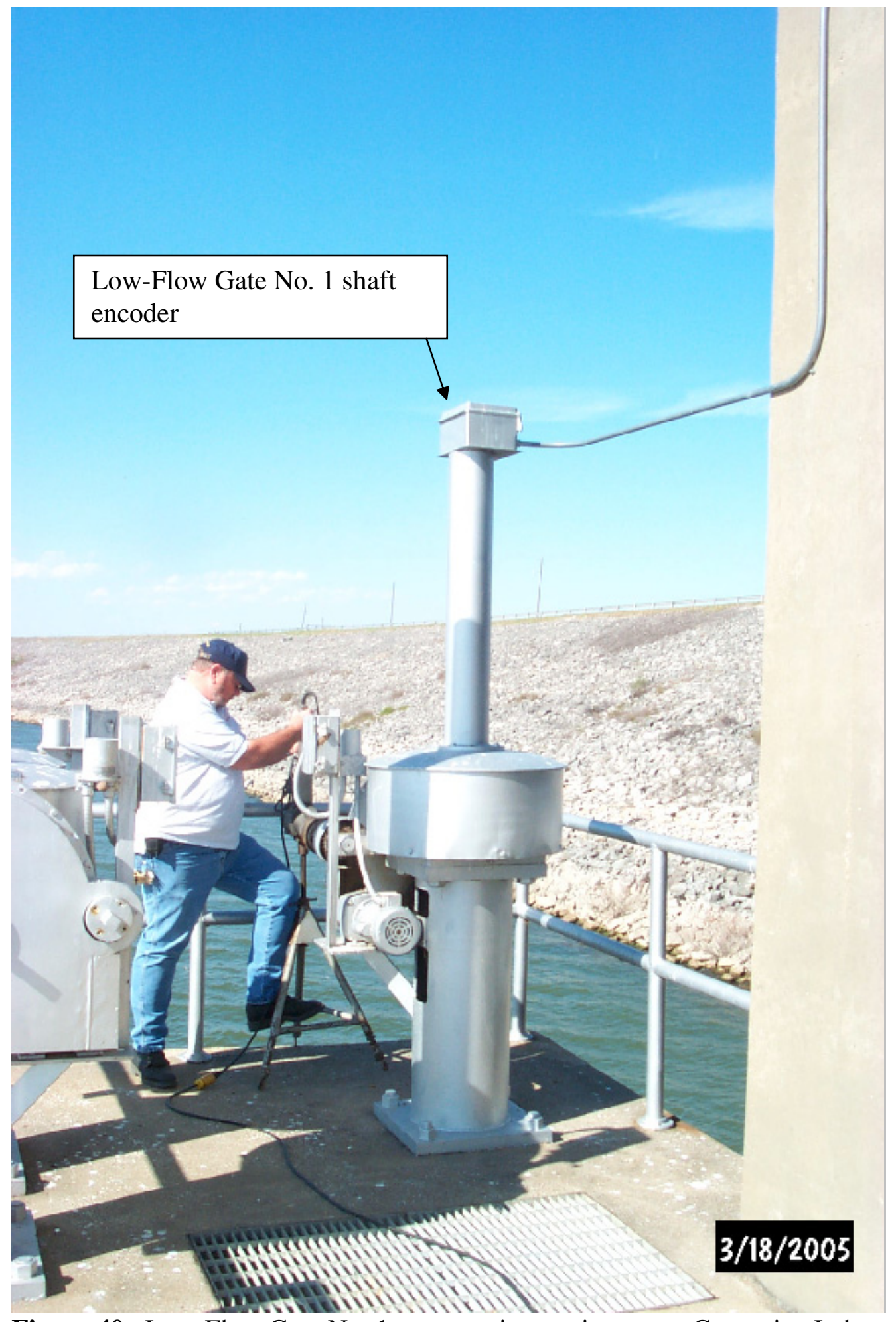

Figure 40. Low-Flow Gate No. 1 gate-sensing equipment at Grapevine Lake. 


\section{Grapevine Lake Sutron 8210 Setup File (GPVT2.SET)}

; 8210/8200 ASCII setup file, can be converted back to a .SET file with WSETMGR.EXE

;

; MAIN SETUP

;

Setup_Version $=$ V6X

Unit_ID=GPVT2

Measurement_Interval=00:15:00

Sampling_Interval=00:00:00

Measurement_Time $=00: 00: 00$

Sampling_Time $=00: 00: 00$

Switched_Power_Time $=00: 00: 00$

Samples_to_Average $=10$

Measurements_per_Log $=1$

Switched_Power_Mode $=\mathrm{ON}$

Recording $=\mathrm{ON}$

Basic_Run_Interval=00:00:00

Basic_Run_Time $=00: 00: 00$

Password=

Number_Resets $=2$

Log_Size $=124928$

Rom_Checksum=57134

; EEROM SETUP

Serial_Port_Mode=USER

User_Baud_Rate $=9600$

Radio_Baud_Rate $=9600$

Com_Baud_Rate $=9600$

Transfer_Baud_Rate $=9600$

SDI_Baud_Rate $=1200$

Enter_Key_Reqd=ON

Log_Dump_Mode=ALL-BIN

User_Time_Limit $=600$

Power_Delay=1

Analog_Delay $=5$

Pressure_Delay $=5$

Auto_Startup_Keys=SSDDDDDDRRPPPDPPDPPD

Time_Format=NORMAL

Date_Format=MDY

Term_Xmit_Delay $=0$

Basic_Size $=1$

Amp_Gain=1.0

;

; PROTOCOL SETUP

Master_Name=

Carrier_Delay $=7$

Com_Port_Mode=

Reply_Delay $=0$

Ack_Delay $=100$ 


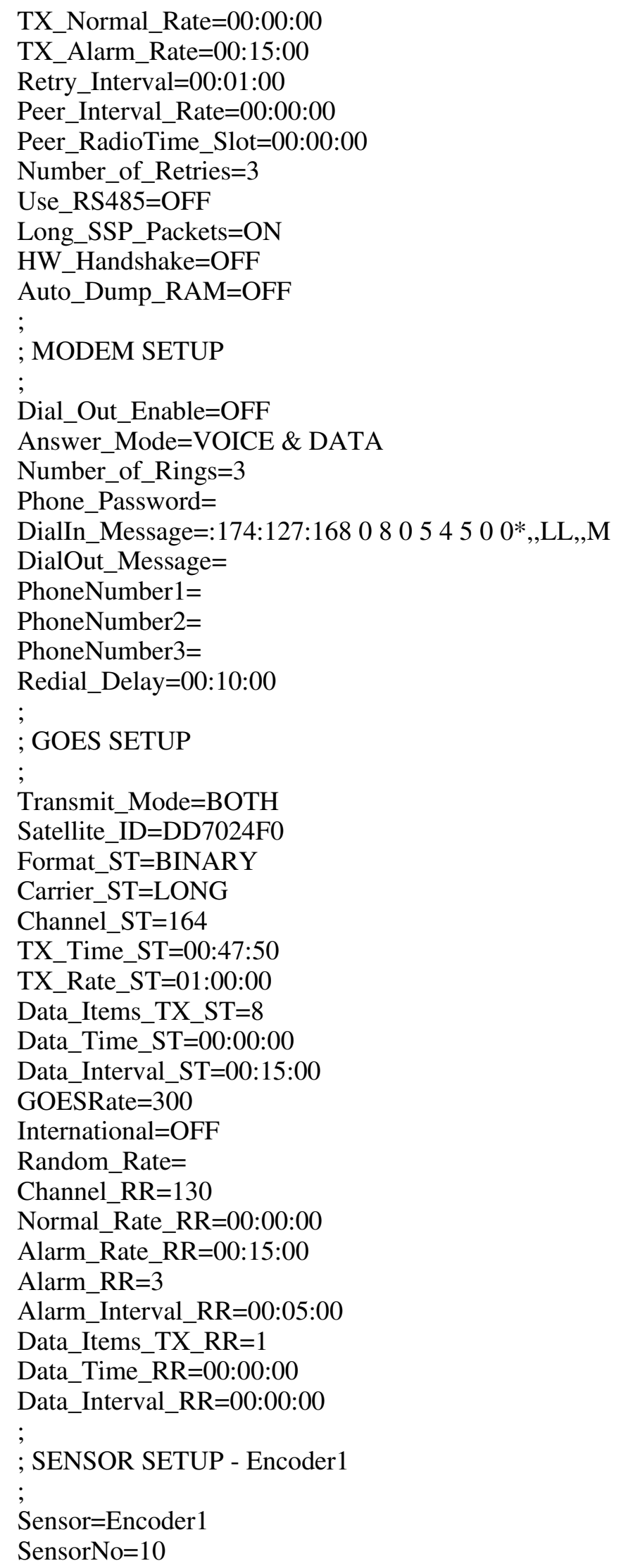




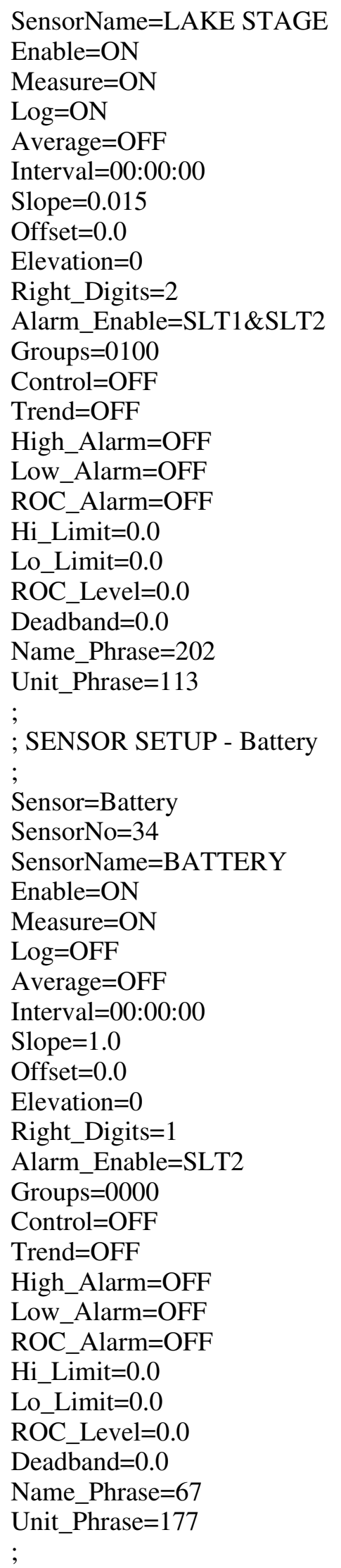




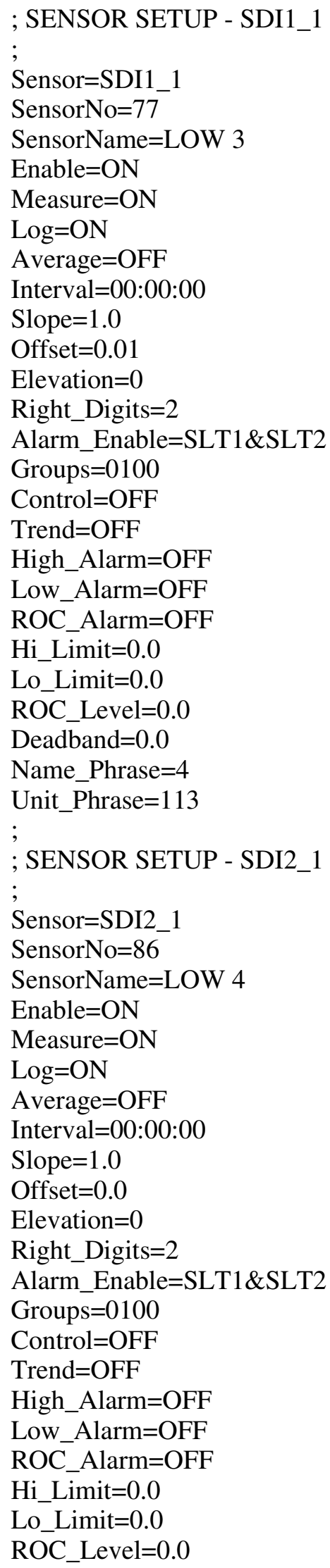




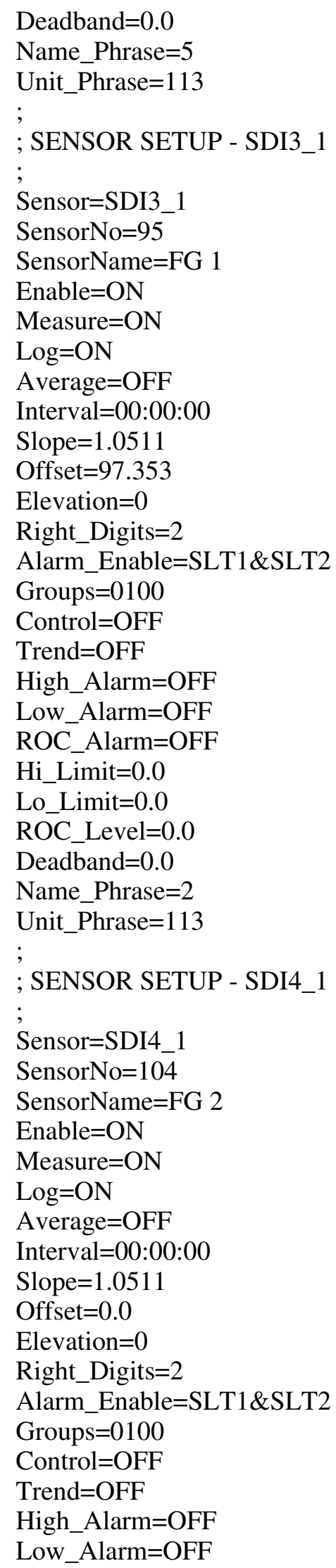


ROC_Alarm=OFF

Hi_Limit $=0.0$

Lo_Limit $=0.0$

ROC_Level $=0.0$

Deadband $=0.0$

Name_Phrase $=3$

Unit_Phrase $=113$

;

; SENSOR SETUP - SDI5_3

Sensor=SDI5 3

SensorNo $=115$

SensorName=TOT_RFACM

Enable $=\mathrm{ON}$

Measure $=\mathrm{ON}$

$\mathrm{Log}=\mathrm{ON}$

Average $=\mathrm{OFF}$

Interval=00:00:00

Slope $=1.0$

Offset $=0.0$

Elevation $=0$

Right_Digits=3

Alarm_Enable=SLT1 $\&$ SLT2

Groups $=0100$

Control $=\mathrm{OFF}$

Trend $=\mathrm{OFF}$

High_Alarm=OFF

Low_Alarm $=\mathrm{OFF}$

ROC_Alarm $=$ OFF

Hi_Limit $=0.0$

Lo_Limit $=0.0$

ROC_Level $=0.0$

Deadband $=0.0$

Name_Phrase $=152$

Unit_Phrase $=124$ 


\section{Jim Chapman Lake Near Cooper, Tex.}

\section{Location}

Lat $33^{\circ} 20^{\prime} 00^{\prime \prime}$, long 95³7'30", Hopkins County, in intake structure on South Sulphur River, about 4.0 mi southeast of Cooper, and 23.2 mi from mouth.

\section{Road Log}

From USGS Texas WSC-Fort Worth, follow I-20 east to I-635 north. Follow I-635 north to I-30 east. Continue on I-30 east to SH 19 near Sulphur Springs. Exit onto SH 19 and travel north about 15 mi to Cooper Lake sign (USACE office). Turn left at sign and continue on road past USACE office to intake structure on dam.

\section{Access}

Before visiting the site, call the Jim Chapman Lake USACE office at 903-945-2108 to let them know you will be servicing the site. The keys required to access the equipment are available from staff at the WSC-Fort Worth. An alarm is on the door to the intake structure; the code to disarm the system is in the field folder for the site. If the keys are not available, have USACE staff open the gate to the intake structure and the intake structure itself.

\section{Equipment Description}

Refer to table 8, "Jim Chapman lake equipment inventory," for a complete list of equipment and to figures 41-45 for equipment wiring diagrams and photographs of equipment. Two main floodgates and two emergency gates are raised and lowered by Limitorque electric valve operators. The naming convention at Jim Chapman Lake is confusing because there are several names for the same piece of equipment. Floodgates No. 1 and No. 2 are labeled Service Gates \#10 and \#9, respectively. The Vorne digital display labels for the two floodgates are FG10 and FG9. Throughout this discussion they will be referred to as Floodgates No. 1 and No. 2, or FG1 and FG2. Floodgate No. 1 is on the right side of the intake structure (facing upstream) and Floodgate No. 2 is on the left. The emergency gates are labeled Emergency Gates \#8 and \#7 and are on the right and left side, respectively, of the intake structure. Also in operation are two low-flow gates labeled Low-Flow Service Gates \#6 and \#5. They will be referred to in this discussion as Low-Flow Gates No. 1 and No. 2 or LOW1 and LOW2 to be consistent with naming conventions at other dams. Low-Flow Gate No. 1 is the same as G-6 and Low-Flow Gate No. 2 is the same as G-5. Both of these also use Limitorque electric valve operators to raise and lower the gates. Four selective withdrawal gates allow water to be pulled from different depths through the two low-flow gates. They are labeled Low-Flow Selector Gates \#1, \#2, \#3, and \#4.

Both floodgates use Shand \& Jurs 92020 automatic tank level gages to indicate the position of the gates. Position is relayed to a Sutron 8210 datalogger with Whessoe Varec 8200 series liquid level transmitters.

A steel tape runs from the top of each floodgate to the 92020 tank level gage where it wraps around a storage drum connected to a Neg' ator constant-force spring 
motor. The Neg'ator spring motor consists of a pre-stressed stainless steel tape that is formed into a coil and stored on a small storage drum. The free end of the coil is wrapped backwards onto a larger output drum and then fastened to the drum. When the steel tape connected to the top of the gate winds up in the 92020 gage as the gate is raised, the tape of the Neg'ator spring motor will wind up onto the small storage drum. Conversely, when the steel tape connected to the top of the gate unwinds as the gate is lowered, the tape of the Neg'ator spring motor will unwind from the small storage drum and wind up on the output drum. In both instances the Neg'ator spring motor functions to provide a constant amount of force (torque) on the steel tape attached to the gate regardless of the amount of deflection. The movement of the small storage drum rotates a shaft inside the 8200 position transmitter. The shaft is coupled to a worm gear, which in turn drives the shaft of a potentiometer. Rotation of the shaft causes a change in the output current of the transmitter. The variations in current output are carried to the Sutron 8210 datalogger by two wires. At the datalogger, the current is passed through a resistor so a voltage can be measured. The output current of the transmitters varies from 4 to $20 \mathrm{~mA}$.

Gate-sensing equipment that serves as a reference for the two floodgates is not available at Jim Chapman Dam. The Shand \& Jurs and Whessoe Varec units are assumed to measure the true position of the gates. Both floodgates also have shaft encoders in place but currently (2005) they are not being used. The pointer and ruler on both of the low-flow gates serve as the reference for the shaft encoders.

The low-flow gates have Handar shaft encoders that send a signal to the Sutron datalogger to indicate the position of the gates. A metal tape goes over the pulley of the shaft encoder and is connected to a pointer that protrudes from the stem cover. As the gate is raised and lowered, the tape rotates around the pulley and the pointer moves up and down along a ruler that indicates gate position. The rotation of the pulley indicates the amount of linear displacement. The positions of both low-flow gates are recorded by the Sutron datalogger.

The Sutron 8210 datalogger is powered by a 12-VDC battery, which is charged by an automatic sealed lead-acid battery charger connected to a 120-VAC wall outlet. The position transmitters on the two floodgates are powered by 24 VDC from an onboard transformer inside the Whessoe Varec transmitter. The power going to the transmitters is $120 \mathrm{VAC}$. The wires supplying $120 \mathrm{VAC}$ begin inside the terminal box between the Vorne digital displays.

The setup file (SCLT2.SET) and a basic program file (SCLT2.BAS) for the datalogger are stored on the RAM card that is kept inside the Sutron equipment box. The basic program enables transmission of gate positions from the Sutron datalogger to the Vorne digital displays. A hard copy of the setup file and the basic program file is also kept in the station folder.

The positions of Floodgates No. 1 and No. 2 and Low-Flow Gates No. 1 and No. 2 are transmitted by satellite and posted on the USACE Web site (http://www.swfwc.usace.army.mil) under Daily Reports/Gate Sensor Report. The USACE reports hourly data; however, the Sutron datalogger measures and records the gate position for the four gates every 15 minutes.

Floodgates No. 1 and No. 2 are FG1 and FG2, respectively, in the Sutron datalogger setup file and basic program file. Low-Flow Gates No. 1 and No. 2 (LOW1 and LOW2) are G-6 and G-5, respectively, in the Sutron datalogger setup file. 


\section{Operation and Maintenance}

Operation and maintenance information for the equipment at Jim Chapman Dam includes descriptions of different procedures required to maintain equipment such as routine inspections, recalibration of Floodgates No. 1 and No. 2, recalibration of LowFlow Gates No. 1 and No. 2, and annual inspections. The purpose of a site visit and the actions taken should be documented in the logbook kept near the datalogger. Include the date, time, actions, and personnel conducting the site visit in the logbook. This section lists some of the potential problems that might occur with the equipment in service and possible solutions to the problems. Refer to the Operations Manuals for the individual pieces of equipment when further detail is required. The information included here is basic operations and maintenance information.

For each visit to the site, personnel should carry all of the necessary tools required to service the equipment. The tools required to perform all of the tasks listed include the following:

- Screwdrivers, flat and Phillips head

- Crescent wrench, 10-in.

- Stepladder, 10-ft

- Electrical tape

- Digital multimeter

- Pliers

- Ruler

- Laptop computer capable of connecting (with RS-232 port and 9-pin cable) to Sutron 8210

- Sutron 8210 Operations Manual

- Shand \& Jurs 92020 and 92021 Instruction Manuals

- Whessoe Varec 8200 Installation and Operations Manual

- Battery load tester

- Spare battery

- Flashlight

- Silicone sealant

\section{Procedures during a routine inspection}

- Check the enclosure to the Sutron 8210 datalogger for damage and moisture. If moisture is entering the enclosure, seal any openings with silicone.

- Scroll through the VIEW DATA/LIVE READINGS menu and check that the datalogger is making measurements.

- Check the antennas (data and GPS) and make sure connections are secure and waterproofed. Replace electrical tape around connections if old and brittle.

- Check the battery voltage under the LIVE READINGS menu on the Sutron 8210.

- If voltage is low (less than $11.5 \mathrm{~V}$ ), test the battery with a load tester and make sure the voltage remains above the recommended voltage specific to the load tester being used. Replace battery as needed.

- Remove drain plug on bottom of position sensor and allow water to drain out.

- Check the Vorne digital displays and verify that the displays are reporting the same gate positions as the Sutron 8210 and that display digits are illuminated. 
Note that the digital displays only report the gate positions to two significant figures (0.0) and that the Sutron reports the positions to three (0.00).

- Verify that the Shand \& Jurs position sensors and the Sutron 8210 datalogger measure the same values for the positions of Floodgates No. 1 and No. 2. If they measure the same (within $0.01 \mathrm{ft}$ ), no action is required. If the values differ, refer to the recalibration procedures.

- Verify that the ruler and the pointer on Low-Flow Gates No. 1 and No. 2 measure the same as the shaft encoder and the Sutron datalogger. If they measure the same (within $0.05 \mathrm{ft}$ ), no action is required. If the values differ, check that the tape is not disconnected from the pulley and that the pulley moves freely. If the tape and the pulley check out, refer to the recalibration procedure.

- Before leaving the site, make sure the Sutron 8210 is reading ON \& TX under RECORDING.

\section{Procedures to recalibrate Floodgates No. 1 and No. 2}

- Completely lower the gate requiring calibration and set the Shand \& Jurs position sensor to measure 0.00 . To do this, open the counter access cover on top of the unit above the dial window. Hold the notched wheel, located to the right of the increments wheel, and turn the increments wheel until the counter measures the correct position, 0.00 . If the position sensor measures 0.00 when the gate is lowered completely, only the Sutron requires calibration.

- Caution: Before executing this procedure, make sure the emergency gates are closed. To calibrate the Sutron after setting the Shand \& Jurs unit to measure 0.00 , first record the current slope and offset for the gate being calibrated. Next, set the slope and the offset to 1.00 and 0.00 , respectively. With the gate still completely closed, scroll down to SYSTEM SETUP. Press the right arrow once and scroll down to CONFIG SENSORS. Press the right arrow once and scroll down to the gate that is being calibrated. With the correct gate selected, press the right arrow once and scroll down to VALUE. Enter the correct value, which would be 0.00 , then press the SET button. Next, open the gate as much as possible so that the instrument will be calibrated over the entire range of gate positions. With the gate open as much as possible, enter the value from the Shand \& Jurs dial into the VALUE field and press the SET button. The datalogger will calculate the slope and the offset from the two known positions entered.

- Verify that the Shand \& Jurs position sensor and the Sutron 8210 datalogger are now measuring the same position with the gate open as much as possible. After verification, close the gate completely and check that both measure 0.00 with the gate completely closed. If so, the calibration is complete; if not perform the calibration again.

- Whenever a change is made to the setup file or the basic program in the datalogger, download the new files to the RAM card kept at the site. To do this, insert the RAM card into the socket and turn on the 8210. Scroll down to the DUMP DATA menu. Press the right arrow once, then press the down arrow until WRITE CARD SETUP is displayed. Press the SET button and wait for the files to be transferred from the datalogger to the RAM card. Note that when doing this both the setup file and the basic program get transferred to the RAM card. To transfer the files from the RAM card to the datalogger, scroll down to the DUMP 
DATA menu. Press the right arrow once, then press the down arrow until READ CARD SETUP is displayed. Press the right arrow to access the setup file and the basic program. Press the down arrow to select which file to transfer to the datalogger. Transfer the selected file to the datalogger by pressing the SET button. Transfer both the setup file and the basic program.

- Record changes to the slope or the offset in the logbook.

\section{Procedures to recalibrate Low-Flow Gates No. 1 and No. 2}

- Lower the gate requiring calibration so that it is closed and the rod and pointer read zero. Set the shaft encoder to read zero by adjusting the offset in the datalogger setup file. The slope of the shaft encoders should be set to 0.01 .

- To change the offset or the slope, turn on the Sutron 8210 and press the down arrow to SYSTEM SETUP. Press the right arrow once and the down arrow twice to CONFIG SENSORS. Then press the right arrow once and the down arrow to select LOW FLOW. Next, press the right arrow once, then the down arrow to slope and offset. Press the SET button once when either slope or offset are highlighted. Change the value using the arrow buttons. Right and left arrow buttons move from one digit to the next. Up and down arrow buttons increase or decrease the value, respectively. When finished, press the SET button to save the new value. Check LIVE READINGS to verify that the new measured value is 0.00 with the gate closed.

- Open the gate to its previous position (if open) and verify that the Sutron and the rod and pointer read the same.

- Record changes to the slope or offset in the logbook and save the new setup file to the RAM card.

\section{Procedures during an annual inspection}

- During an inspection the emergency gates are lowered, and the floodgates are raised all the way up and cleaned and inspected. As the gates are lowered after being serviced, check that the position sensors and datalogger measure the same values. If not, follow the instructions to recalibrate the instruments.

- After the inspection, follow all of the procedures during a routine inspection. 
Table 8. Jim Chapman Lake equipment inventory

[See table of contents for abbreviated units; --, not available or not applicable]

\begin{tabular}{|c|c|c|c|c|}
\hline $\begin{array}{l}\text { Item } \\
\text { no. }\end{array}$ & Item description & Manufacturer & Model no. & Remarks \\
\hline 1. & Floodgate No. 1 position sensor & Shand \& Jurs & 92020 & $\begin{array}{l}\text { Gate is FG1 in Sutron setup and equipment is labeled Service } \\
\text { Gate \#10 }\end{array}$ \\
\hline 2. & $\begin{array}{l}\text { Floodgate No. } 1 \text { position } \\
\text { transmitter }\end{array}$ & Whessoe Varec & 82001200 & $\begin{array}{l}\text { Analog transmitter with current output of } 4 \text { to } 20 \mathrm{~mA} \text { and input } \\
\text { of } 15 \text { to } 48 \mathrm{VDC}\end{array}$ \\
\hline 3. & Wire for position transmitter No. 1 & -- & -- & $30 \mathrm{ft}$ of $16 \mathrm{AWG} / 2$ wires \\
\hline 4. & Floodgate No. 2 position sensor & Shand \& Jurs & 92020 & $\begin{array}{l}\text { Gate is FG2 in Sutron setup and equipment is labeled Service } \\
\text { Gate \#9 }\end{array}$ \\
\hline 5. & $\begin{array}{l}\text { Floodgate No. } 2 \text { position } \\
\text { transmitter }\end{array}$ & Whessoe Varec & 82001200 & $\begin{array}{l}\text { Analog transmitter with current output of } 4 \text { to } 20 \mathrm{~mA} \text { and input } \\
\text { of } 15 \text { to } 48 \mathrm{VDC}\end{array}$ \\
\hline 6. & Wire for position transmitter No. 2 & -- & -- & $45 \mathrm{ft}$ of $16 \mathrm{AWG} / 2$ wires \\
\hline 7. & $\begin{array}{l}\text { Low-Flow Gate No. } 1 \text { position } \\
\text { sensor }\end{array}$ & Handar & $436 \mathrm{~A}$ & $\begin{array}{l}\text { Gate is G-6 in Sutron setup and equipment is labeled Low- } \\
\text { Flow Service Gate \#6 }\end{array}$ \\
\hline 8. & $\begin{array}{l}\text { Wire for Low-Flow Gate No. } 1 \\
\text { position sensor }\end{array}$ & -- & -- & $45 \mathrm{ft}$ of $22 \mathrm{AWG} / 4$ wires \\
\hline 9. & $\begin{array}{l}\text { Low-Flow Gate No. } 2 \text { position } \\
\text { sensor }\end{array}$ & Handar & $436 \mathrm{~A}$ & $\begin{array}{l}\text { Gate is G-5 in Sutron setup and equipment is labeled Low- } \\
\text { Flow Service Gate \#5 }\end{array}$ \\
\hline 10. & $\begin{array}{l}\text { Wire for Low-Flow Gate No. } 2 \\
\text { position sensor }\end{array}$ & -- & -- & $65 \mathrm{ft}$ of $22 \mathrm{AWG} / 4$ wires \\
\hline 11. & Stage shaft encoder & Sutron & $56-0540$ & -- \\
\hline 12. & Rain gage & Design Analysis & $\mathrm{H}-340$ & -- \\
\hline 13. & Datalogger & Sutron & 8210 & -- \\
\hline 14. & $\begin{array}{l}\text { Digital display for Floodgates No. } \\
1 \text { and No. } 2\end{array}$ & Vorne Industries & GY2200 & $\begin{array}{l}\text { Connected to Sutron } 8210 \text { through RS-232 9-pin cable and } \\
\text { powered by } 120 \text {-VAC wall outlet }\end{array}$ \\
\hline 15. & Battery & Power Sonic & PS-12550U & $12-\mathrm{V}, 55.0-\mathrm{A}-\mathrm{h}$. battery for Sutron 8210 \\
\hline 16. & Battery charger & Ever Start & WM-1-12A & $12-\mathrm{V}, 1.5-\mathrm{A}$ \\
\hline 17. & Antenna & -- & YAGI & Mounted on side of intake structure \\
\hline 18. & Antenna cable & Olympic & RG 8/U & 20 -ft cable from Sutron 8210 to antenna \\
\hline 19. & Antenna polyphaser & PolyPhaser & IS-50NX-C1 & -- \\
\hline 20. & Data transmitter & Sutron & Satlink & -- \\
\hline 21. & GPS antenna & Trimble & Miniature 5V & Magnetic mount \\
\hline 22. & GPS antenna cable & Trimble & -- & Cable comes with antenna \\
\hline
\end{tabular}




\section{Job Hazard Analysis}

Required protective clothing, safety equipment, and supplies: Personal flotation device (PFD), reflective vest, gloves, steel-toed shoes, waders, cell phone, first aid kit, fire extinguisher, rotating or strobe type emergency lights, drinking water.

\begin{tabular}{|c|c|c|}
\hline $\begin{array}{l}\text { Sequence of basic } \\
\text { job steps }\end{array}$ & $\begin{array}{l}\text { Potential } \\
\text { accident or hazard }\end{array}$ & Recommended safe job procedures \\
\hline $\begin{array}{l}\text { Upon job } \\
\text { assignment }\end{array}$ & $\begin{array}{l}\text { Water-related accident or } \\
\text { injury }\end{array}$ & $\begin{array}{l}\text { Employees working in and around water must receive } \\
\text { training specified in WRD Memo 2000.10, "Policy for } \\
\text { safety training associated with over-water activities." }\end{array}$ \\
\hline $\begin{array}{l}\text { Loading and } \\
\text { unloading } \\
\text { equipment }\end{array}$ & $\begin{array}{l}\text { Pinched fingers, mashed } \\
\text { toes, or strained back }\end{array}$ & $\begin{array}{l}\text { Be aware of hand placement. Wear protective gloves and } \\
\text { steel-toed shoes. Use proper lifting techniques. Lift with } \\
\text { legs. Use extra caution lifting heavy sounding weights. }\end{array}$ \\
\hline $\begin{array}{l}\text { Driving to and } \\
\text { returning from work } \\
\text { site }\end{array}$ & $\begin{array}{l}\text { Traffic accidents, vehicle } \\
\text { flooding, or drowning }\end{array}$ & $\begin{array}{l}\text { Drivers of USGS vehicles must have Drivers Safety } \\
\text { Training (SM 445-2-H, chap. 16). Be alert to traffic in } \\
\text { area, obey all traffic laws, and reduce speed when weather } \\
\text { conditions are bad. Do not drive across flooded highways } \\
\text { unless water depth and bridge conditions are known to be } \\
\text { safe. }\end{array}$ \\
\hline Parking vehicle & $\begin{array}{l}\text { Personal and vehicle } \\
\text { safety when exiting } \\
\text { vehicle in traffic; bank } \\
\text { collapse or bridge failure }\end{array}$ & $\begin{array}{l}\text { Use rotating or strobe emergency lights, follow site } \\
\text { traffic-control plan, wear DOT Type III reflective vest } \\
\text { when working in or near roadway. Park away from stream } \\
\text { at a safe distance from banks. }\end{array}$ \\
\hline $\begin{array}{l}\text { Set up traffic- } \\
\text { control equipment }\end{array}$ & $\begin{array}{l}\text { Personal and public } \\
\text { safety }\end{array}$ & $\begin{array}{l}\text { Employees working in or near roadways must have Work } \\
\text { Zone Traffic-Control Safety Training. Remain alert to } \\
\text { traffic conditions. }\end{array}$ \\
\hline $\begin{array}{l}\text { Working at field } \\
\text { site }\end{array}$ & Drowning & $\begin{array}{l}\text { Employees are required to wear a PFD when working in, } \\
\text { on, or over any body of water. There are no exemptions } \\
\text { for employees in the Texas WSC. PFDs will be } \\
\text { international orange in color and equipped with reflective } \\
\text { tape in accordance with } 46 \text { CFR } 25.25-15 \text {. Self-inflating } \\
\text { PFDs are not to be worn by employees who have not had } \\
\text { In-Water Safety Training. }\end{array}$ \\
\hline $\begin{array}{l}\text { Working at field } \\
\text { site }\end{array}$ & Trips, slips, and falls & $\begin{array}{l}\text { Follow path clear of obstructions and with minimal slope; } \\
\text { avoid slippery surfaces. Walk cautiously on steep slopes } \\
\text { or paths with loose material. Use appropriate footwear for } \\
\text { the terrain and conditions. Follow the safest, not the } \\
\text { fastest path! }\end{array}$ \\
\hline $\begin{array}{l}\text { Working at field } \\
\text { site }\end{array}$ & $\begin{array}{l}\text { Dehydration, heat } \\
\text { exhaustion, heat stroke, } \\
\text { or sunburn }\end{array}$ & $\begin{array}{l}\text { Drink plenty of water or electrolyte drink. Wear } \\
\text { appropriate clothing. Take occasional breaks and watch } \\
\text { for symptoms of heat exhaustion. Use sun block. }\end{array}$ \\
\hline $\begin{array}{l}\text { Working at field } \\
\text { site }\end{array}$ & Hypothermia or frostbite & $\begin{array}{l}\text { Wear foul-weather gear during winter months. Keep } \\
\text { clothing dry. }\end{array}$ \\
\hline $\begin{array}{l}\text { Working at field } \\
\text { site }\end{array}$ & Snake bites & $\begin{array}{l}\text { Wear appropriate foot and leg protection. Watch path } \\
\text { ahead. Keep area around gage clear of brush. If bitten, } \\
\text { seek immediate medical help. }\end{array}$ \\
\hline
\end{tabular}




\begin{tabular}{|l|l|l|}
\hline $\begin{array}{l}\text { Working at field } \\
\text { site }\end{array}$ & Poisonous plants & $\begin{array}{l}\text { Know how to identify poisonous plants. Wear protective } \\
\text { clothing. Wash and flush exposed areas immediately with } \\
\text { cold water. Wash with degreasing type soap and flush } \\
\text { from skin. Seek medical attention for severe reactions. }\end{array}$ \\
\hline Entering gage house & $\begin{array}{l}\text { Infectious disease or air } \\
\text { borne pollutants; risk of } \\
\text { hantavirus exposure. }\end{array}$ & $\begin{array}{l}\text { Watch for bat or rodent nests and droppings. If nest or } \\
\text { droppings are present, do not disturb dust. Gage should be } \\
\text { periodically cleaned to minimize risk of exposure. See } \\
\text { WRD memo dated 10/28/97, "Preventing hantavirus } \\
\text { disease," and OP memo dated 01/94, "Instructions for } \\
\text { preventing hantavirus disease." }\end{array}$ \\
\hline Entering gage house & Insect or snake bite & $\begin{array}{l}\text { Inspect in and around shelter for harmful insects. Use } \\
\text { wasp or insect spray. Inspect in and around shelter for } \\
\text { snakes prior to entry. }\end{array}$ \\
\hline
\end{tabular}

\section{Site-Specific Job Hazards}

The items listed are safety issues specific to this site that deserve special emphasis.

- Use caution when removing cover to the Whessoe Varec position transmitters. The power supply line going to the units are $120 \mathrm{VAC}$. Disconnect power to transmitters prior to opening them up.

- The Vorne digital displays are about $12 \mathrm{ft}$ off the floor of the intake structure and therefore require a stepladder when being checked or changed out.

- The low-flow gate shaft encoders are about $12 \mathrm{ft}$ off the floor and also require a stepladder to service. 
Figure 41. Jim Chapman Lake Sutron 8210 wiring panel.

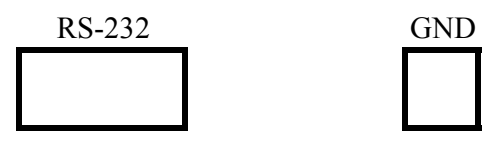

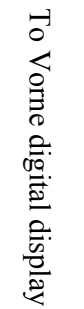

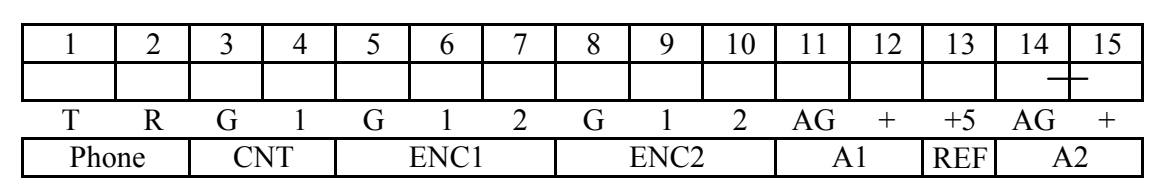

\begin{tabular}{|c|c|c|c|c|c|c|c|}
\hline 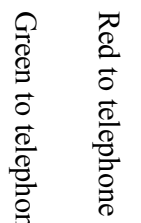 & 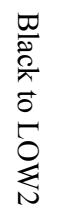 & 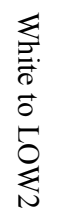 & $\begin{array}{l}\stackrel{0}{0} \\
\mathbb{0} \\
\stackrel{\Xi}{\Xi} \\
0 \\
5 \\
0 \\
\sum_{N}\end{array}$ & 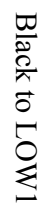 & 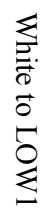 & 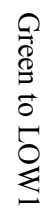 & $\begin{array}{l}\square \\
\widetilde{\sigma} \\
0 \\
0 \\
\mathbb{T} \\
\Omega\end{array}$ \\
\hline
\end{tabular}

Note: LOW2, Low-Flow Gate No. 2 or G-5 (Sutron setup file name). LOW1, Low-Flow Gate No. 1 or G-6 (Sutron setup file name).

FG1, Floodgate No. 1.

FG2, Floodgate No. 2.

+ denotes a resistor between the two ports of the Sutron.

\begin{tabular}{|c|c|c|c|c|c|c|c|c|c|c|c|c|c|c|}
\hline Ext Batt & \multicolumn{1}{c|}{ RS485 } & \multicolumn{5}{c|}{ SDI-12 } & \multicolumn{5}{c|}{ SDI-12 } & \multicolumn{5}{c|}{ Digital Output } \\
\hline $\mathrm{G}$ & + & A & B & G & + & D & G & + & D & 1 & 2 & 3 & 4 & 5 \\
\hline & & & & & & & & & & & & & & \\
\hline 1 & 2 & 3 & 4 & 5 & 6 & 7 & 8 & 9 & 10 & 11 & 12 & 13 & 14 & 15 \\
\hline
\end{tabular}

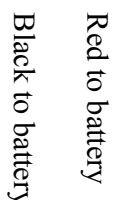
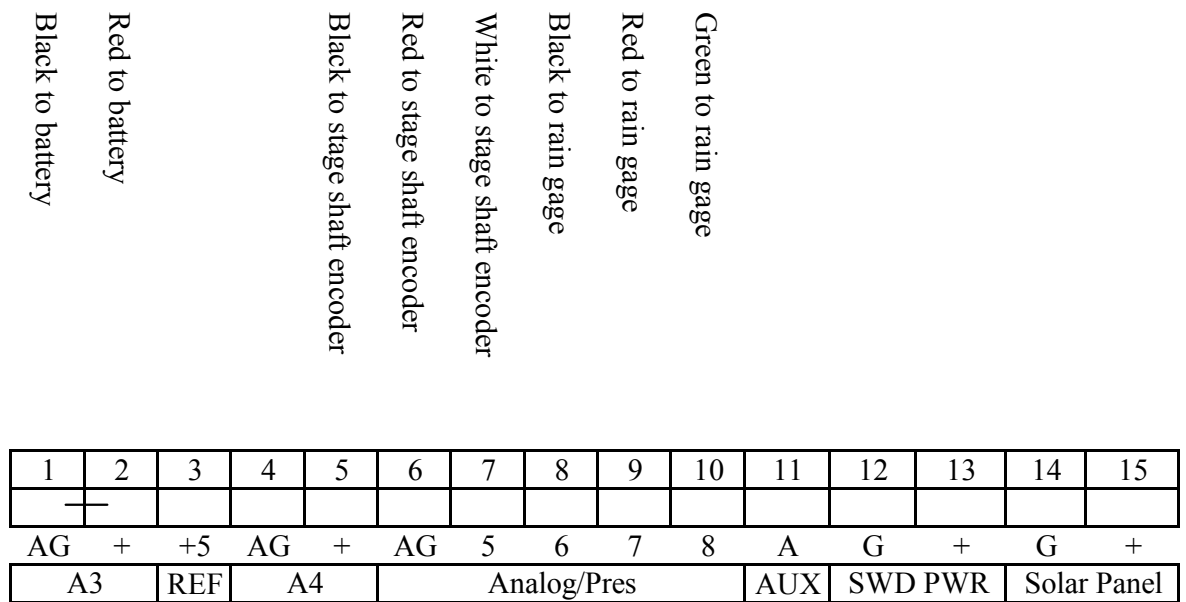

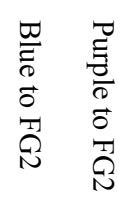

0
0
0
0
0
$\vdots$
0
0
0
0
0
0 
Figure 42. Jim Chapman Lake equipment wiring diagram.
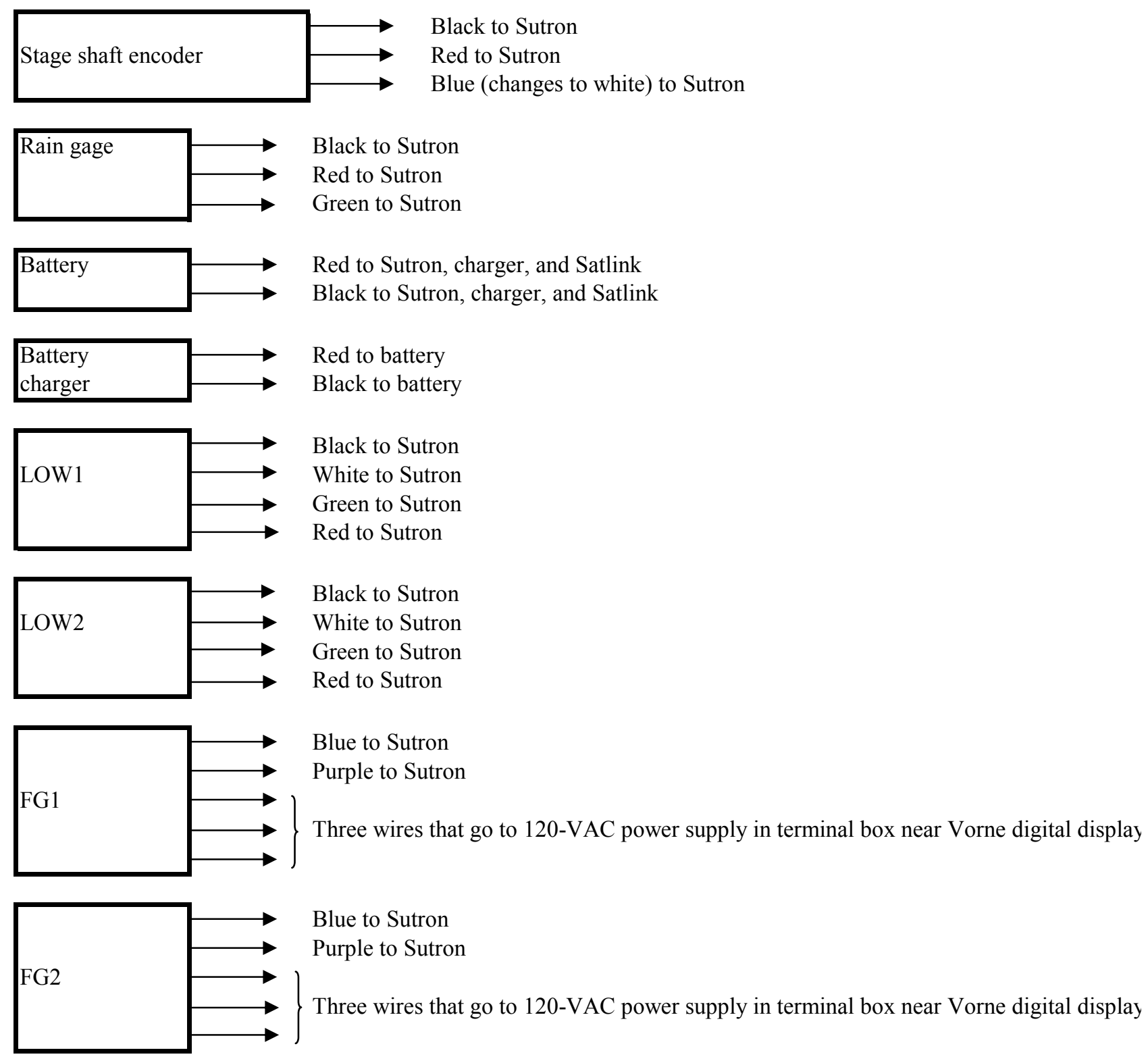

Note: $\quad$ LOW1, Low-Flow Gate No. 1 or G-6 (Sutron setup file name).

LOW2, Low-Flow Gate No. 2 or G-5 (Sutron setup file name).

FG1, Floodgate No. 1.

FG2, Floodgate No. 2. 


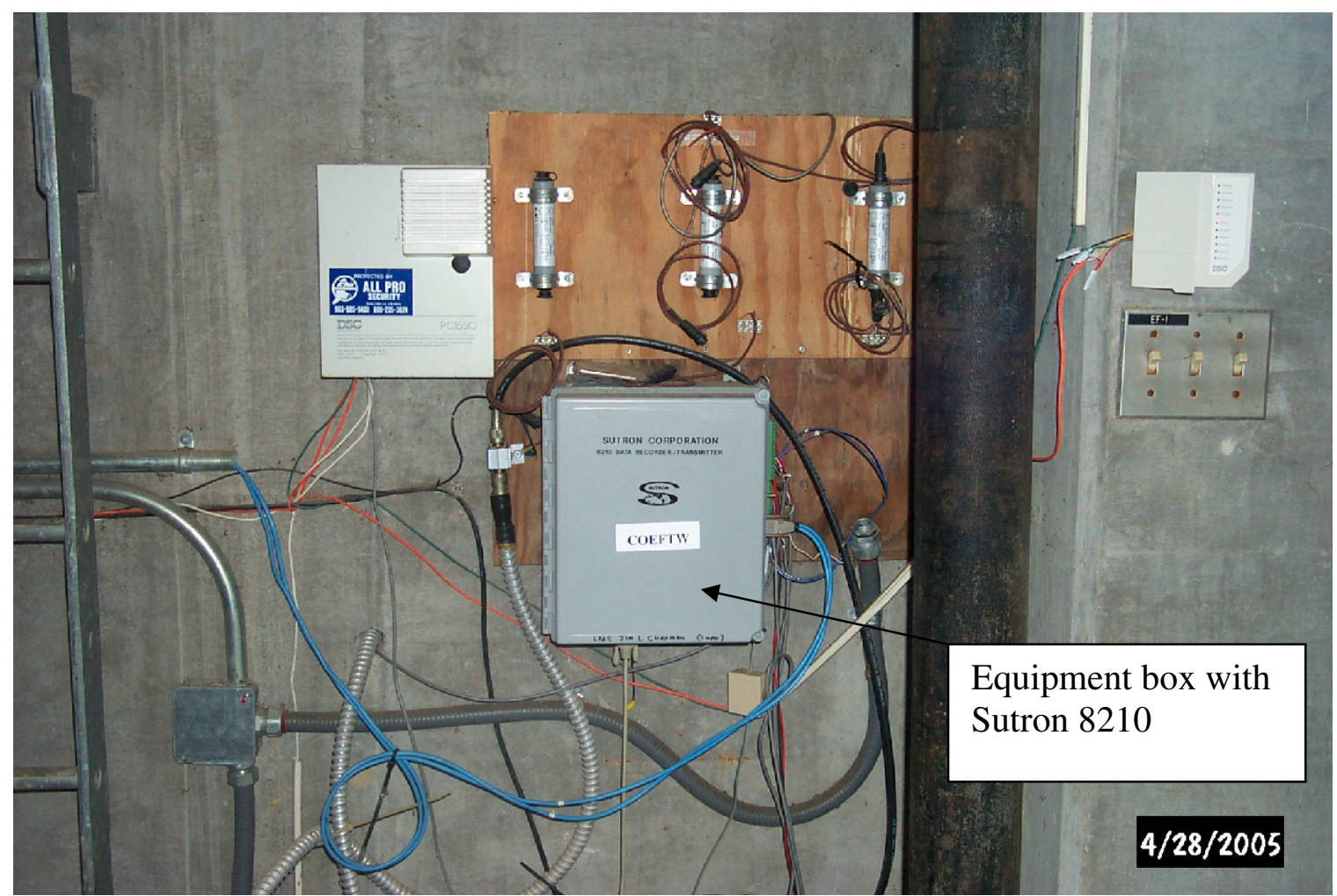

Figure 43. Equipment box at Jim Chapman Lake.

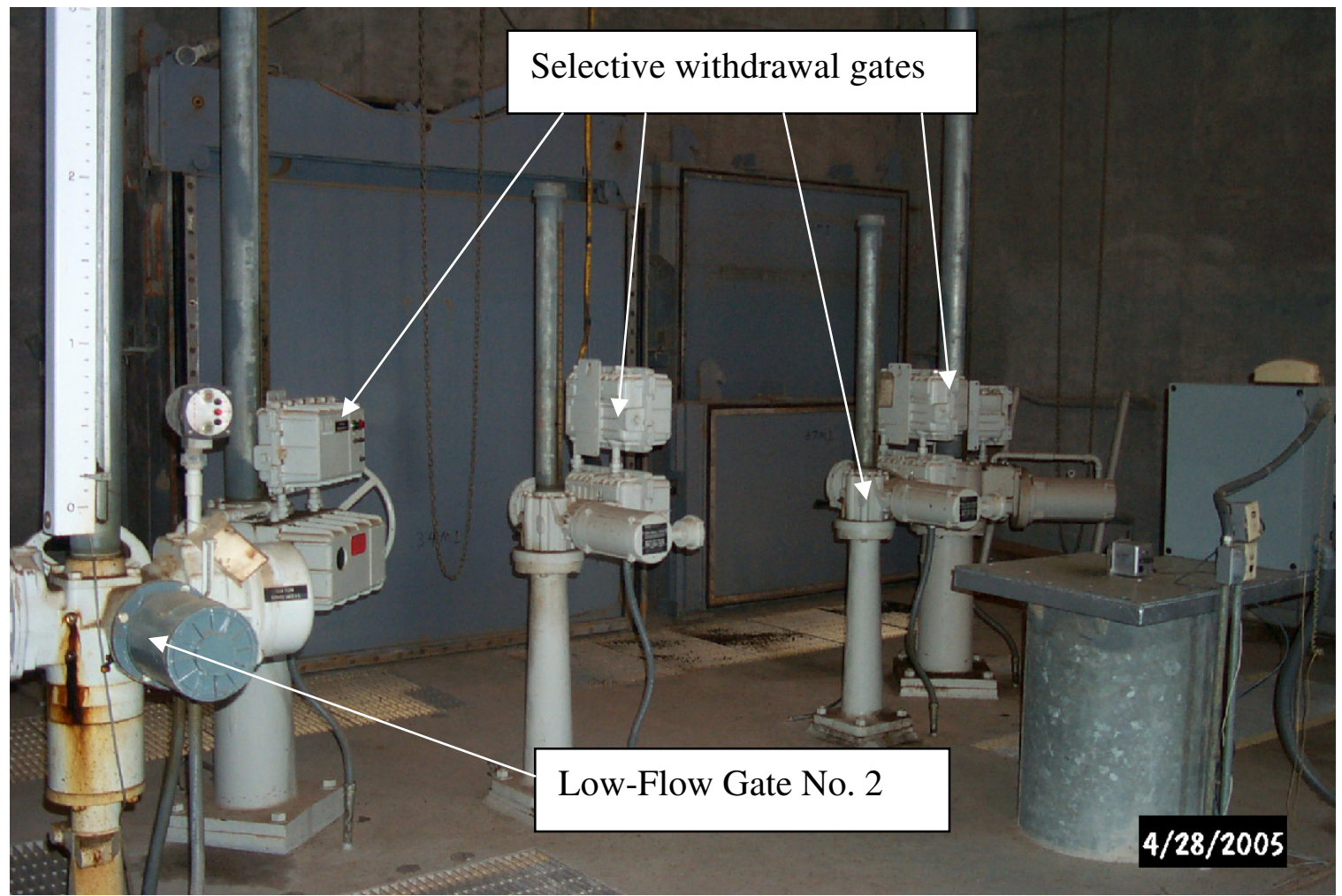

Figure 44. Low-Flow Gate No. 2 and withdrawal gates at Jim Chapman Lake. 


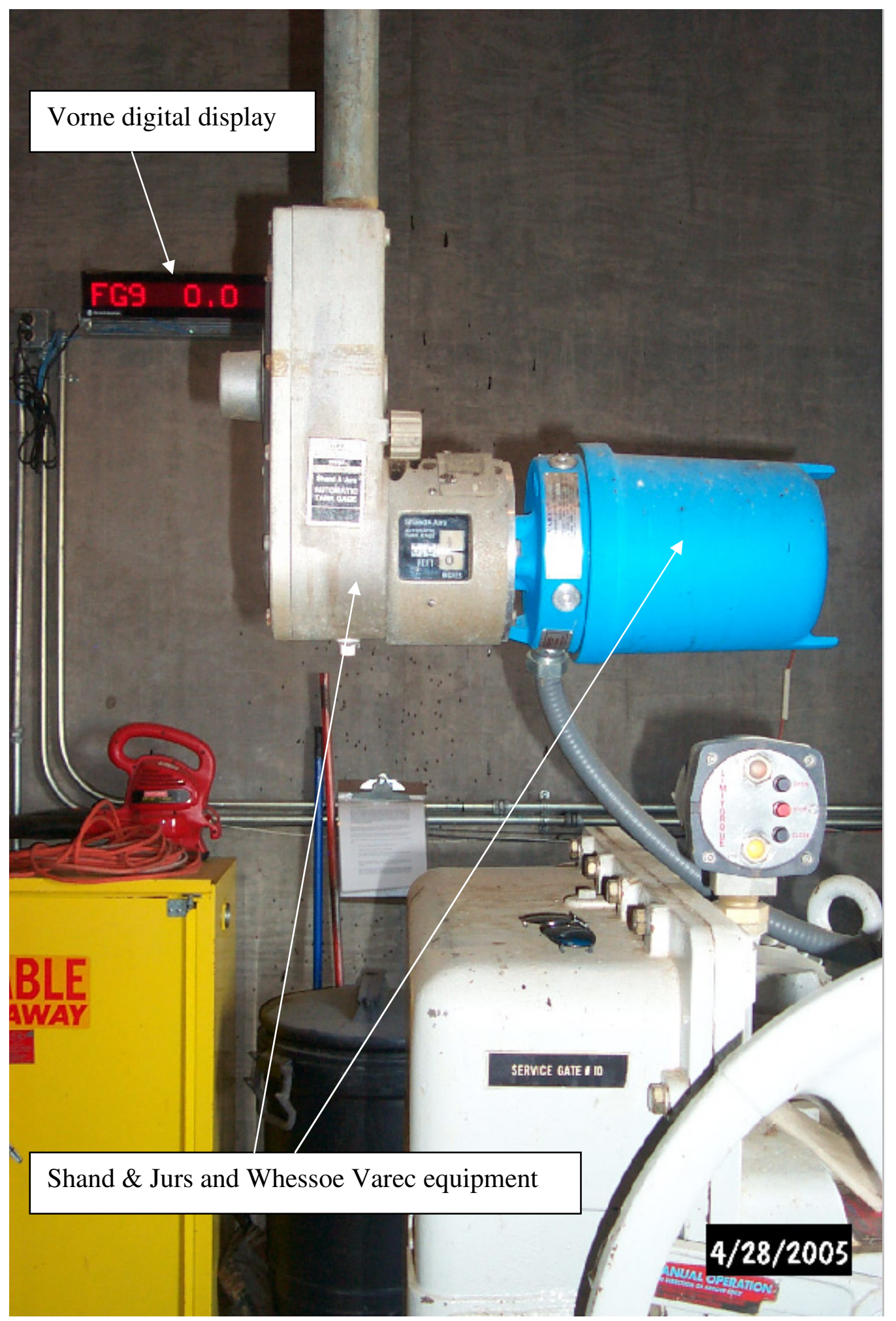

Figure 45. Floodgate No. 1 equipment and digital display at Jim Chapman Lake. 


\section{Jim Chapman Lake Sutron 8210 Setup File (SCLT2.SET)}

; 8210/8200 ASCII setup file, can be converted back to a .SET file with WSETMGR.EXE

;

; MAIN SETUP

;

Setup_Version $=$ V6X

Unit_ID=SCLT2

Measurement_Interval=00:15:00

Sampling_Interval=00:00:00

Measurement_Time $=00: 00: 00$

Sampling_Time $=00: 00: 00$

Switched_Power_Time $=00: 00: 00$

Samples_to_Average $=10$

Measurements_per_Log=1

Switched_Power_Mode $=\mathrm{ON}$

Recording $=\mathrm{ON}$

Basic_Run_Interval $=00: 00: 02$

Basic_Run_Time $=00: 00: 00$

Password=

Number_Resets $=23$

Log_Size $=124928$

Rom_Checksum=57134

;

; EEROM SETUP

Serial_Port_Mode=USER

User_Baud_Rate $=9600$

Radio_Baud_Rate $=9600$

Com_Baud_Rate $=9600$

Transfer_Baud_Rate $=9600$

SDI_Baud_Rate $=1200$

Enter_Key_Reqd=ON

Log_Dump_Mode=ALL-BIN

User_Time_Limit $=600$

Power_Delay $=1$

Analog_Delay $=5$

Pressure_Delay $=5$

Auto_Startup_Keys=SS

Time_Format=NORMAL

Date_Format=MDY

Term_Xmit_Delay $=0$

Basic_Size $=1$

Amp_Gain=1.0

;

; PROTOCOL SETUP

Master_Name=

Carrier_Delay=7

Com_Port_Mode=

Reply_Delay $=0$

Ack_Delay $=100$ 


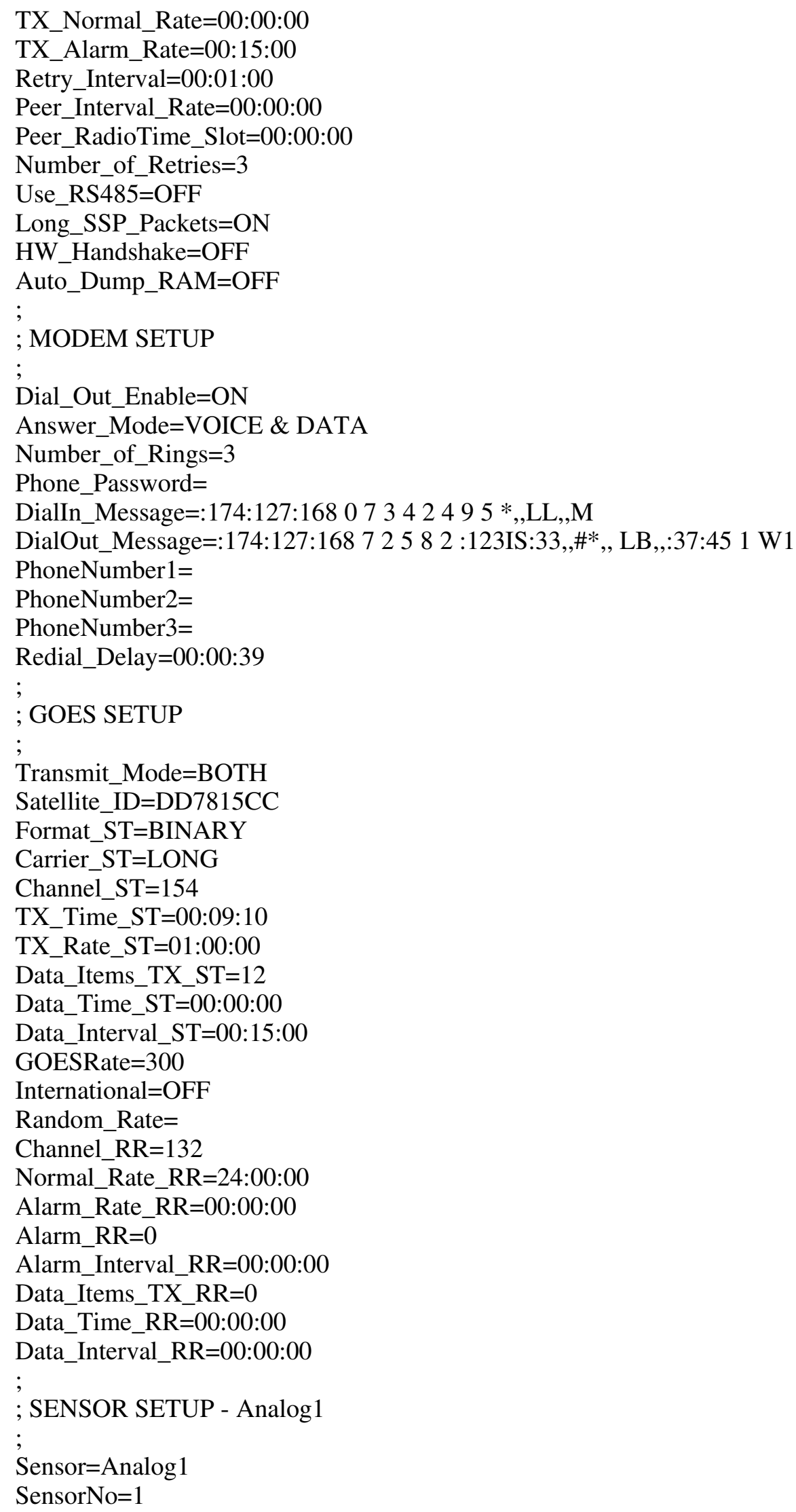




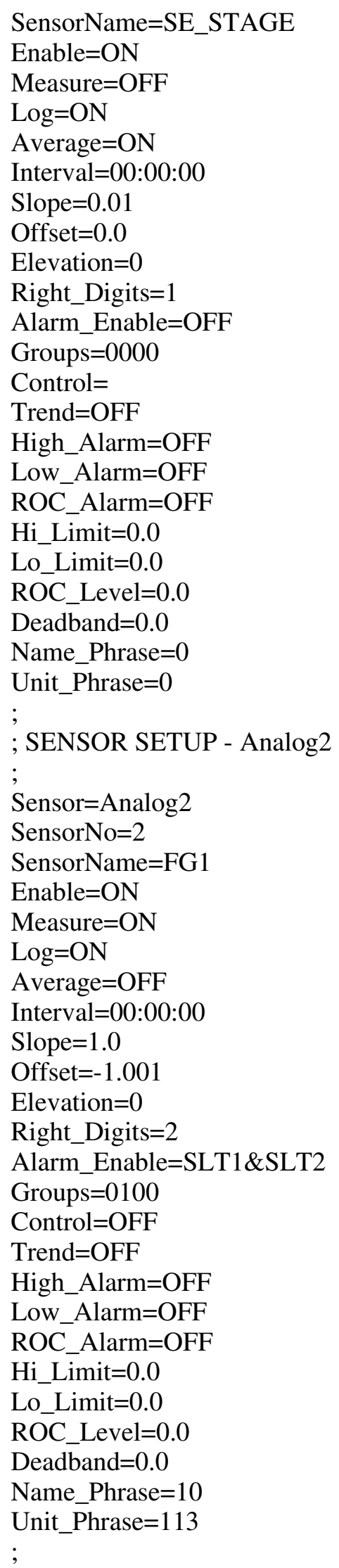




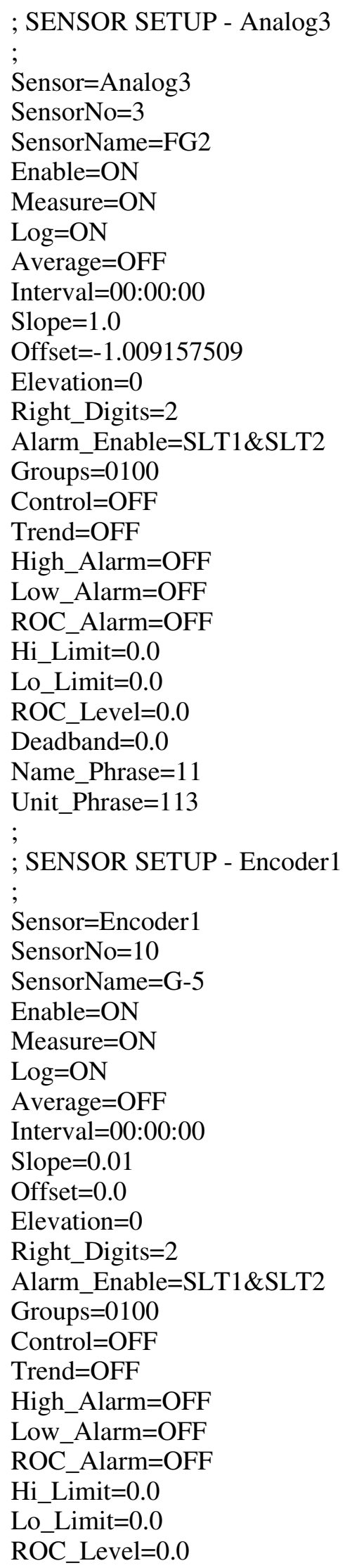




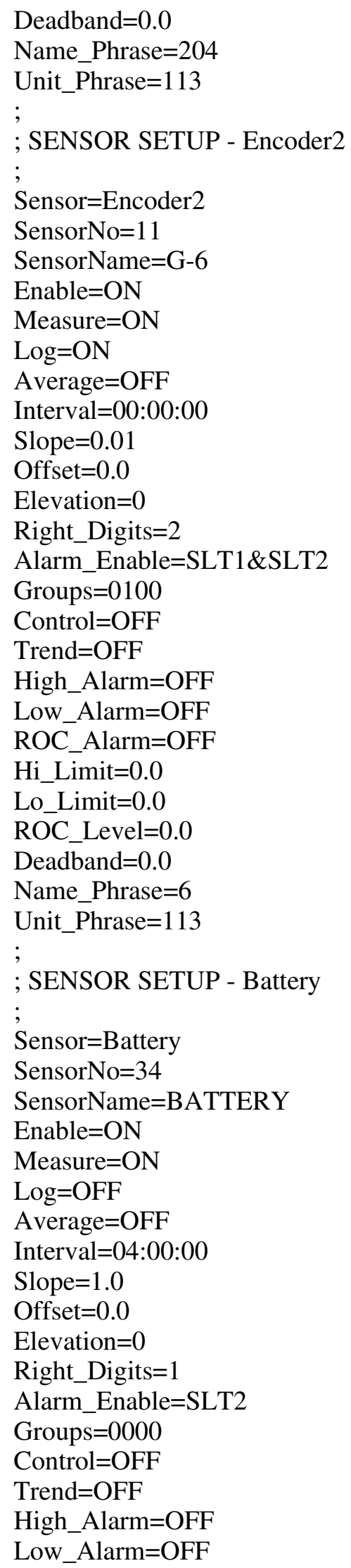




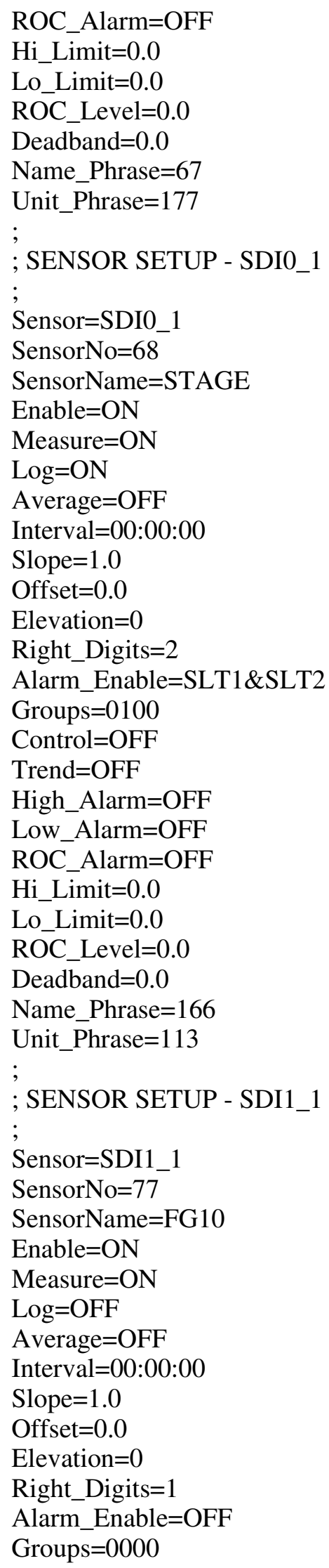




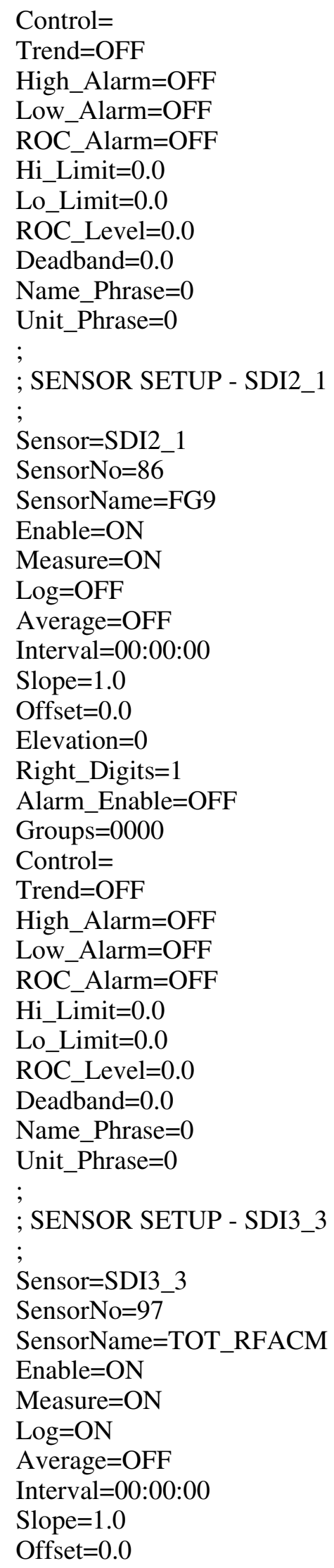


Elevation $=0$

Right_Digits=3

Alarm_Enable=SLT1\&SLT2

Groups $=0100$

Control $=\mathrm{OFF}$

Trend $=\mathrm{OFF}$

High_Alarm=OFF

Low_Alarm $=\mathrm{OFF}$

ROC_Alarm $=$ OFF

Hi_Limit $=0.0$

Lo_Limit $=0.0$

ROC_Level $=0.0$

Deadband $=0.0$

Name_Phrase $=152$

Unit_Phrase=124

\section{Jim Chapman Lake Sutron 8210 Basic Program (SCLT2.BAS)}

5 ' COE Ft Worth Dam Automation Cooper Lake

$10 \mathrm{a}=$ Measure(FG1)

$20 \mathrm{~b}=$ Measure(FG2)

30 ' $\mathrm{c}=$ Measure(SDI0_3)

40 ' $\mathrm{d}=$ Measure(SDI0_4)

50 Open "TERM:" nowait

60 Control 1,2

70 Control 11, 9600

80 ?27\$;48\$449;

90 ?"FG10 ";:?A!2!1

100 Print $27 \$ ; 48 \$ ; 50 \$ ;$

110 Print "FG9 ";:PRINT B!2!1

120 ' Print 27\$;48;51\$;

130 ' Print "G3 ";:PRINT C!2!2

140 ' Print 27\$;48;52\$;

150 ' Print "G4 ";:PRINT D!2!2

160 control 2 : close

$162 \log$ time ,FG10,a:log time ,FG9,b:log time ,SE_STAGE,STAGE

170 Stop

$1000 \mathrm{z}=$ MEASURE(STAGE):SE_STAGE $=\mathrm{z}$

65100 RUNLINE SE_STAGE, 1000 


\section{Joe Pool Lake Near Duncanville, Tex.}

\section{Location}

Lat $32^{\circ} 38^{\prime} 36^{\prime \prime}$, long $97^{\circ} 00^{\prime} 03^{\prime \prime}$, Dallas County, in intake structure of Joe Pool Dam, 0.7 mi upstream from bridge over Mountain Creek on Camp Wisdom Rd., $1.0 \mathrm{mi}$ downstream from John Penn Branch, $5.5 \mathrm{mi}$ west of water towers in downtown Duncanville, 7.1 mi upstream from Mountain Creek Dam on Mountain Creek, and 11.2 mi upstream from mouth.

\section{Road Log}

From USGS Texas WSC-Fort Worth, take I-20 east to Grand Prairie (about 15 mi). Exit onto FM 1382 (also called Belt Line Rd.) and travel south about 4 mi. Turn right onto the road that leads to the USACE office.

\section{Access}

Before visiting the site, call the Joe Pool Dam USACE office at 972-299-2227 to let them know you will be servicing the site. The keys required to access the equipment are available from staff at the WSC-Fort Worth. One key is for the gate to the restricted road (on top of the dam) that leads to the intake structure; one key is for the gate leading to the intake structure; and one key is for the door of the intake structure. There is also a key to disable the alarm system before entering the intake structure. Ask USACE staff how to disable the alarm system and how to enable when leaving.

\section{Equipment Description}

Refer to table 9, "Joe Pool Lake equipment inventory," for a complete list of equipment and to figures 46-51 for equipment wiring diagrams and photographs of equipment. Two main floodgates and two emergency gates are raised and lowered by Limitorque electric valve operators. Floodgates No. 1 and No. 2 are labeled FG1 and FG2; the emergency gates are labeled EG1 and EG2. Floodgate No. 1 is on the right side of the intake structure (facing upstream) and Floodgate No. 2 is on the left. Similarly, Emergency Gates No. 1 and No. 2 are located on the right and left sides (facing upstream), respectively, of the intake structure. The low-flow gate (not labeled) is between the two emergency gates; a Limitorque electric valve operator also is used to raise and lower the low-flow gate. Four selective withdrawal gates allow water to be pulled from different depths through the low-flow gate. They are labeled LF1, LF2, LF3, and LF4.

The positions of the two floodgates are displayed on Vorne digital displays. Floodgate No. 1 is posted on the left display and Floodgate No. 2 is on the right. They are labeled G1 and G2 on the displays.

Both floodgates use Shand \& Jurs 92020 automatic tank level gages to indicate the position of the gates. Position is relayed to a Sutron 8210 datalogger with Whessoe Varec 8200 series liquid level transmitters. The emergency gates do not have Shand \& 
Jurs gages or Whessoe Varec transmitters; therefore, the position of the gates is not recorded by the datalogger.

A steel tape runs from the top of each floodgate to the 92020 tank level gage, where it wraps around a storage drum connected to a Neg'ator constant-force spring motor. The Neg'ator spring motor consists of a prestressed stainless steel tape that is formed into a coil and stored on a small storage drum. The free end of the coil is wrapped backwards onto a larger output drum, then fastened to the drum. When the steel tape connected to the top of the gate winds up in the 92020 gage as the gate is raised, the tape of the Neg'ator spring motor will wind up onto the small storage drum. Conversely, when the steel tape connected to the top of the gate unwinds as the gate is lowered, the tape of the Neg'ator spring motor will unwind from the small storage drum and wind up on the output drum. In both instances the Neg'ator spring motor functions to provide a constant amount of force (torque) on the steel tape attached to the gate regardless of the amount of deflection. The movement of the small storage drum rotates a shaft inside the 8200 position transmitter. The shaft is coupled to a worm gear, which in turn drives the shaft of a potentiometer. Rotation of the shaft causes a change in the output current of the transmitter. The variations in current output are carried to the Sutron 8210 datalogger by two wires. At the datalogger, the current is passed through a resistor so the voltage can be measured. The output current of the transmitters varies from 4 to $20 \mathrm{~mA}$.

Gate-sensing equipment that serves as a reference for the two floodgates is not available at Joe Pool Dam. The Shand \& Jurs and Whessoe Varec units are assumed to measure the true position of the gates. The pointer and ruler on the low-flow gate serve as the reference for the shaft encoder.

The low-flow gate has a Sutron shaft encoder that sends a signal to the Sutron datalogger to indicate gate position. A metal tape goes over the pulley of the shaft encoder and is connected to a pointer that protrudes from the stem cover. As the gate is raised and lowered, the tape rotates around the pulley and the pointer moves up and down along a ruler that indicates gate position. The rotation of the pulley indicates the amount of linear displacement and is recorded by the datalogger.

The Sutron 8210 datalogger is powered by a 12-VDC battery, which is charged by an automatic sealed lead-acid battery charger connected to a $120-\mathrm{VAC}$ wall outlet. The position transmitters on the two floodgates are powered by 24 VDC from an onboard transformer inside the Whessoe Varec transmitter. The power going to the transmitters is $120 \mathrm{VAC}$. The wires supplying $120 \mathrm{VAC}$ begin inside the terminal box between the Vorne digital displays.

The setup file (JPLK.SET) and a basic program file (JPLK.BAS) for the datalogger are stored on the RAM card that is kept inside the Sutron equipment box. The basic program enables transmission of gate positions from the Sutron datalogger to the Vorne digital displays. A hard copy of the setup file and the basic program file is also kept in the station folder.

The positions of Floodgates No. 1 and No. 2 and the low-flow gate are transmitted by satellite and posted on the USACE Web site (http://www.swf-wc.usace.army.mil) under Daily Reports/Gate Sensor Report. The USACE reports hourly data; however, the Sutron datalogger measures and records the gate position for the three gates every 15 minutes. 
Floodgates No. 1 and No. 2 are ANALOG1 and ANALOG2, respectively, and the low-flow gate is LOW FLOW in the Sutron setup file.

The floodgates also have shaft encoders but they are not in service. In the Sutron setup file two sensors, FG1 and FG2, are setup as SDI12 sensors with addresses 0 and 1, respectively. In the past these probably were for the shaft encoders, but currently (2005) they are not being used.

\section{Operation and Maintenance}

Operation and maintenance information for the equipment at Joe Pool Dam includes descriptions of different procedures required to maintain equipment such as routine inspections, recalibration of Floodgates No. 1 and No. 2, recalibration of the lowflow gate, and annual inspections. The purpose of a site visit and the actions taken should be documented in the logbook kept near the datalogger. Include the date, time, actions, and personnel conducting the site visit in the logbook. This section lists some of the potential problems that might occur with the equipment in service and possible solutions to the problems. Refer to the Operations Manuals for the individual pieces of equipment when further detail is required. The information included here is basic operations and maintenance information.

For each visit to the site, personnel should carry all of the necessary tools required to service the equipment. The tools required to perform all of the tasks listed include the following:

- Screwdrivers, flat and Phillips head

- Crescent wrench, 10-in.

- Stepladder, 10-ft

- Electrical tape

- Digital multimeter

- Pliers

- Ruler

- Laptop computer capable of connecting (with RS-232 port and 9-pin cable) to Sutron 8210

- Sutron 8210 Operations Manual

- Shand \& Jurs 92020 and 92021 Instruction Manuals

- Whessoe Varec 8200 Installation and Operations Manual

- Battery load tester

- Spare battery

- Flashlight

- Silicone sealant

\section{Procedures during a routine inspection}

- Check the enclosure to the Sutron 8210 datalogger for damage and moisture. If moisture is entering the enclosure, seal any openings with silicone.

- Scroll through the VIEW DATA/LIVE READINGS menu and check that the datalogger is making measurements. 
- Check the antennas (data and GPS) and make sure connections are secure and waterproofed. Replace electrical tape around connections if old and brittle.

- Check the battery voltage under the LIVE READINGS menu on the Sutron 8210.

- If voltage is low (less than $11.5 \mathrm{~V}$ ), test the battery with a load tester and make sure the voltage remains above the recommended voltage specific to the load tester being used. Replace battery as needed.

- Remove drain plug on bottom of position sensor and allow water to drain out.

- Check the Vorne digital displays and verify that the displays are reporting the same gate positions as the Sutron 8210 and that display digits are illuminated. Note that the digital displays only report the gate positions to two significant figures (0.0) and that the Sutron reports the positions to three (0.00).

- Verify that the Shand \& Jurs position sensors and the Sutron 8210 datalogger measure the same values for the positions of Floodgates No. 1 and No. 2. If they measure the same (within $0.01 \mathrm{ft}$ ), no action is required. If the values differ, refer to the recalibration procedures.

- Verify that the ruler and the pointer on the low-flow gate measure the same as the shaft encoder and the Sutron datalogger. If they measure the same (within $0.05 \mathrm{ft}$ ), no action is required. If the values differ, check that the tape is not disconnected from the pulley and that the pulley moves freely. If the tape and the pulley check out, refer to the recalibration procedure.

- Before leaving the site, make sure the Sutron 8210 is reading ON \& TX under RECORDING.

\section{Procedures to recalibrate Floodgates No. 1 and No. 2}

- Completely lower the gate requiring calibration and set the Shand \& Jurs position sensor to measure 0.00 . To do this, open the counter access cover on top of the unit above the dial window. Hold the notched wheel, located to the right of the increments wheel, and turn the increments wheel until the counter measures the correct position, 0.00 . If the position sensor measures 0.00 when the gate is lowered completely, only the Sutron requires calibration.

- Caution: Before executing this procedure, make sure the emergency gates are closed. To calibrate the Sutron after setting the Shand \& Jurs unit to measure 0.00 , first record the current slope and offset for the gate being calibrated. Next, set the slope and the offset to 1.00 and 0.00 , respectively. With the gate still completely closed, scroll down to SYSTEM SETUP. Press the right arrow once and scroll down to CONFIG SENSORS. Press the right arrow once and scroll down to the gate that is being calibrated. With the correct gate selected, press the right arrow once and scroll down to VALUE. Enter the correct value, which would be 0.00 , then press the SET button. Next, open the gate as much as possible so that the instrument will be calibrated over the entire range of gate positions. With the gate open as much as possible, enter the value from the Shand \& Jurs dial into the VALUE field and press the SET button. The datalogger will calculate the slope and the offset from the two known positions entered.

- Verify that the Shand \& Jurs position sensor and the Sutron 8210 datalogger are now measuring the same position with the gate open as much as possible. After verification, close the gate completely and check that both measure 0.00 with the 
gate completely closed. If so, the calibration is complete; if not, perform the calibration again.

- Whenever a change is made to the setup file or the basic program in the datalogger, download the new files to the RAM card kept at the site. To do this, insert the RAM card into the socket and turn on the 8210. Scroll down to the DUMP DATA menu. Press the right arrow once, then press the down arrow until WRITE CARD SETUP is displayed. Press the SET button and wait for the files to be transferred from the datalogger to the RAM card. Note that when doing this both the setup file and the basic program get transferred to the RAM card. To transfer the files from the RAM card to the datalogger, scroll down to the DUMP DATA menu. Press the right arrow once, then press the down arrow until READ CARD SETUP is displayed. Press the right arrow to access the setup file and the basic program. Press the down arrow to select which file to transfer to the datalogger. Transfer the selected file to the datalogger by pressing the SET button. Transfer both the setup file and the basic program.

- Record changes to the slope or the offset in the logbook.

\section{Procedures to recalibrate the low-flow gate}

- Lower the gate so that it is closed and the rod and pointer read zero. Set the Sutron shaft encoder to read zero by adjusting the offset in the datalogger setup file. The slope of the shaft encoder should be set to 1.0 as one revolution of the wheel is $1 \mathrm{ft}$.

- To change the offset or the slope, turn on the Sutron 8210 and press the down arrow to SYSTEM SETUP. Press the right arrow once and the down arrow twice to CONFIG SENSORS. Then press the right arrow once and the down arrow to select LOW FLOW. Next, press the right arrow once, then the down arrow to slope and offset. Press the SET button once when either slope or offset are highlighted. Change the value using the arrow buttons. Right and left arrow buttons move from one digit to the next. Up and down arrow buttons increase or decrease the value, respectively. When finished, press the SET button to save the new value. Check LIVE READINGS to verify that the new measured value is 0.00 with the gate closed.

- Open the low-flow gate to its previous position (if open) and verify that the Sutron and the rod and pointer read within $0.05 \mathrm{ft}$ of each other.

- Record changes to the slope or offset in the logbook and save the new setup file to the RAM card.

\section{Procedures during an annual inspection}

- During an inspection the emergency gates are lowered, and the floodgates are raised all the way up and cleaned and inspected. As the gates are lowered after being serviced, check that the position sensors and datalogger measure the same values. If not, follow the instructions to recalibrate the instruments.

- After the inspection, follow all of the procedures during a routine inspection. 
Table 9. Joe Pool Lake equipment inventory.

[See table of contents for abbreviated units; --, not available or not applicable]

\begin{tabular}{|c|c|c|c|c|}
\hline $\begin{array}{c}\text { Item } \\
\text { no. }\end{array}$ & Item description & Manufacturer & Model no. & Remarks \\
\hline 1. & Floodgate No. 1 position sensor & Shand \& Jurs & 92020 & $\begin{array}{l}\text { Gate is ANALOG1 in Sutron setup and equipment is } \\
\text { labeled FG1 }\end{array}$ \\
\hline 2. & $\begin{array}{l}\text { Floodgate No. } 1 \text { position } \\
\text { transmitter }\end{array}$ & Whessoe Varec & 82001200 & $\begin{array}{l}\text { Analog transmitter with current output of } 4 \text { to } 20 \mathrm{~mA} \text {; } \\
120 \text { VAC to transmitter with onboard power supply } \\
\text { converting to } 24 \text { VDC }\end{array}$ \\
\hline 3. & Wire for position transmitter No. 1 & -- & -- & $95 \mathrm{ft}$ of $16 \mathrm{AWG} / 2$ wires \\
\hline 4. & Floodgate No. 2 position sensor & Shand \& Jurs & 92020 & $\begin{array}{l}\text { Gate is ANALOG2 in Sutron setup and equipment is } \\
\text { labeled FG2 }\end{array}$ \\
\hline 5. & $\begin{array}{l}\text { Floodgate No. } 2 \text { position } \\
\text { transmitter }\end{array}$ & Whessoe Varec & 82001200 & $\begin{array}{l}\text { Analog transmitter with current output of } 4 \text { to } 20 \mathrm{~mA} \text {; } \\
120 \text { VAC to transmitter with onboard power supply } \\
\text { converting to } 24 \text { VDC }\end{array}$ \\
\hline 6. & Wire for position transmitter No. 2 & -- & -- & $80 \mathrm{ft}$ of $16 \mathrm{AWG} / 2$ wires \\
\hline 7. & Low-flow gate position sensor & Sutron & SE8500 & $\begin{array}{l}\text { Gate is LOW FLOW in Sutron setup but no label on } \\
\text { equipment; shaft encoder has SDI12 address } 3\end{array}$ \\
\hline 8. & $\begin{array}{l}\text { Wire from low-flow gate position } \\
\text { sensor to Sutron } 8210\end{array}$ & -- & -- & $26 \mathrm{ft}$ of $24 \mathrm{AWG} / 6$ wires with only 3 wires used \\
\hline 9. & Stage shaft encoder & Sutron & SE8500 & STAGE in Sutron setup; has SDI12 address 2 \\
\hline 10. & Rain gage & $\begin{array}{l}\text { Texas Electronics, } \\
\text { Inc. }\end{array}$ & TR-525I & -- \\
\hline 11. & Datalogger & Sutron & 8210 & -- \\
\hline 12. & $\begin{array}{l}\text { Digital display for Floodgates No. } \\
1 \text { and No. } 2\end{array}$ & Vorne Industries & GY2200 & $\begin{array}{l}\text { Connected to Sutron } 8210 \text { through RS-232 9-pin cable ( } 35 \\
\text { ft) and powered by } 120-\text { VAC wall outlet }\end{array}$ \\
\hline 13. & Battery & Power Sonic & PS-12550U & $12-\mathrm{V}, 55.0-\mathrm{A}-\mathrm{h}$. battery for Sutron 8210 \\
\hline 14. & Battery charger & Power Sonic & PSC-12500A & $12-\mathrm{V}, 500-\mathrm{mA}$ \\
\hline 15. & Antenna & -- & -- & Mounted on upstream side of intake structure \\
\hline 16. & Antenna cable & Saxton & $8282 \mathrm{RG} 8 / \mathrm{U}$ & 14-ft cable from Sutron 8210 to antenna \\
\hline 17. & Data transmitter & Sutron & Satlink & $\begin{array}{l}\text { Mounted inside intake structure on upstream side; requires } \\
\text { about } 14 \mathrm{ft} \text { of GPS cable to go from transmitter to antenna }\end{array}$ \\
\hline 18. & $\begin{array}{l}\text { Wire from data transmitter to } \\
\text { battery }\end{array}$ & -- & -- & $\begin{array}{l}30 \mathrm{ft} \text { of } 16 \mathrm{AWG} / 4 \text { wires (only two are used) to carry } \\
\text { power from battery to transmitter }\end{array}$ \\
\hline 19. & $\begin{array}{l}\text { Cable (9-pin) from data transmitter } \\
\text { to Sutron } 8210\end{array}$ & -- & -- & $30 \mathrm{ft}$ of cable required \\
\hline
\end{tabular}




\section{Job Hazard Analysis}

Required protective clothing, safety equipment, and supplies: Personal flotation device (PFD), reflective vest, gloves, steel-toed shoes, waders, cell phone, first aid kit, fire extinguisher, rotating or strobe type emergency lights, drinking water.

\begin{tabular}{|c|c|c|}
\hline $\begin{array}{l}\text { Sequence of basic } \\
\text { job steps }\end{array}$ & $\begin{array}{l}\text { Potential } \\
\text { accident or hazard }\end{array}$ & Recommended safe job procedures \\
\hline $\begin{array}{l}\text { Upon job } \\
\text { assignment }\end{array}$ & $\begin{array}{l}\text { Water-related accident or } \\
\text { injury }\end{array}$ & $\begin{array}{l}\text { Employees working in and around water must receive } \\
\text { training specified in WRD Memo 2000.10, "Policy for } \\
\text { safety training associated with over-water activities." }\end{array}$ \\
\hline $\begin{array}{l}\text { Loading and } \\
\text { unloading } \\
\text { equipment }\end{array}$ & $\begin{array}{l}\text { Pinched fingers, mashed } \\
\text { toes, or strained back }\end{array}$ & $\begin{array}{l}\text { Be aware of hand placement. Wear protective gloves and } \\
\text { steel-toed shoes. Use proper lifting techniques. Lift with } \\
\text { legs. Use extra caution lifting heavy sounding weights. }\end{array}$ \\
\hline $\begin{array}{l}\text { Driving to and } \\
\text { returning from work } \\
\text { site }\end{array}$ & $\begin{array}{l}\text { Traffic accidents, vehicle } \\
\text { flooding, or drowning }\end{array}$ & $\begin{array}{l}\text { Drivers of USGS vehicles must have Drivers Safety } \\
\text { Training (SM 445-2-H, chap. 16). Be alert to traffic in } \\
\text { area, obey all traffic laws, and reduce speed when weather } \\
\text { conditions are bad. Do not drive across flooded highways } \\
\text { unless water depth and bridge conditions are known to be } \\
\text { safe. }\end{array}$ \\
\hline Parking vehicle & $\begin{array}{l}\text { Personal and vehicle } \\
\text { safety when exiting } \\
\text { vehicle in traffic; bank } \\
\text { collapse or bridge failure }\end{array}$ & $\begin{array}{l}\text { Use rotating or strobe emergency lights, follow site } \\
\text { traffic-control plan, wear DOT Type III reflective vest } \\
\text { when working in or near roadway. Park away from stream } \\
\text { at a safe distance from banks. }\end{array}$ \\
\hline $\begin{array}{l}\text { Set up traffic- } \\
\text { control equipment }\end{array}$ & $\begin{array}{l}\text { Personal and public } \\
\text { safety }\end{array}$ & $\begin{array}{l}\text { Employees working in or near roadways must have Work } \\
\text { Zone Traffic-Control Safety Training. Remain alert to } \\
\text { traffic conditions. }\end{array}$ \\
\hline $\begin{array}{l}\text { Working at field } \\
\text { site }\end{array}$ & Drowning & $\begin{array}{l}\text { Employees are required to wear a PFD when working in, } \\
\text { on, or over any body of water. There are no exemptions } \\
\text { for employees in the Texas WSC. PFDs will be } \\
\text { international orange in color and equipped with reflective } \\
\text { tape in accordance with } 46 \text { CFR } 25.25-15 \text {. Self-inflating } \\
\text { PFDs are not to be worn by employees who have not had } \\
\text { In-Water Safety Training. }\end{array}$ \\
\hline $\begin{array}{l}\text { Working at field } \\
\text { site }\end{array}$ & Trips, slips, and falls & $\begin{array}{l}\text { Follow path clear of obstructions and with minimal slope; } \\
\text { avoid slippery surfaces. Walk cautiously on steep slopes } \\
\text { or paths with loose material. Use appropriate footwear for } \\
\text { the terrain and conditions. Follow the safest, not the } \\
\text { fastest path! }\end{array}$ \\
\hline $\begin{array}{l}\text { Working at field } \\
\text { site }\end{array}$ & $\begin{array}{l}\text { Dehydration, heat } \\
\text { exhaustion, heat stroke, } \\
\text { or sunburn }\end{array}$ & $\begin{array}{l}\text { Drink plenty of water or electrolyte drink. Wear } \\
\text { appropriate clothing. Take occasional breaks and watch } \\
\text { for symptoms of heat exhaustion. Use sun block. }\end{array}$ \\
\hline $\begin{array}{l}\text { Working at field } \\
\text { site }\end{array}$ & Hypothermia or frostbite & $\begin{array}{l}\text { Wear foul-weather gear during winter months. Keep } \\
\text { clothing dry. }\end{array}$ \\
\hline $\begin{array}{l}\text { Working at field } \\
\text { site }\end{array}$ & Snake bites & $\begin{array}{l}\text { Wear appropriate foot and leg protection. Watch path } \\
\text { ahead. Keep area around gage clear of brush. If bitten, } \\
\text { seek immediate medical help. }\end{array}$ \\
\hline
\end{tabular}




\begin{tabular}{|l|l|l|}
\hline $\begin{array}{l}\text { Working at field } \\
\text { site }\end{array}$ & Poisonous plants & $\begin{array}{l}\text { Know how to identify poisonous plants. Wear protective } \\
\text { clothing. Wash and flush exposed areas immediately with } \\
\text { cold water. Wash with degreasing type soap and flush } \\
\text { from skin. Seek medical attention for severe reactions. }\end{array}$ \\
\hline Entering gage house & $\begin{array}{l}\text { Infectious disease or } \\
\text { airborne pollutants; risk } \\
\text { of hantavirus exposure. }\end{array}$ & $\begin{array}{l}\text { Watch for bat or rodent nests and droppings. If nest or } \\
\text { droppings are present, do not disturb dust. Gage should be } \\
\text { periodically cleaned to minimize risk of exposure. See } \\
\text { WRD memo dated 10/28/97, "Preventing hantavirus } \\
\text { disease," and OP memo dated 01/94, "Instructions for } \\
\text { preventing hantavirus disease." }\end{array}$ \\
\hline Entering gage house & Insect or snake bite & $\begin{array}{l}\text { Inspect in and around shelter for harmful insects. Use } \\
\text { wasp or insect spray. Inspect in and around shelter for } \\
\text { snakes prior to entry. }\end{array}$ \\
\hline
\end{tabular}

\section{Site-Specific Job Hazards}

The items listed are safety issues specific to this site that deserve special emphasis.

- Use caution when removing cover to the Whessoe Varec position transmitters. The power supply line going to the units are $120 \mathrm{VAC}$. Disconnect power to transmitters prior to opening them up.

- The Vorne digital displays are about $12 \mathrm{ft}$ off the floor of the intake structure and therefore require a stepladder when being checked or changed out.

- The low-flow gate shaft encoder is about $12 \mathrm{ft}$ off the floor and also requires a stepladder to service. 
Figure 46. Joe Pool Lake Sutron 8210 wiring panel.
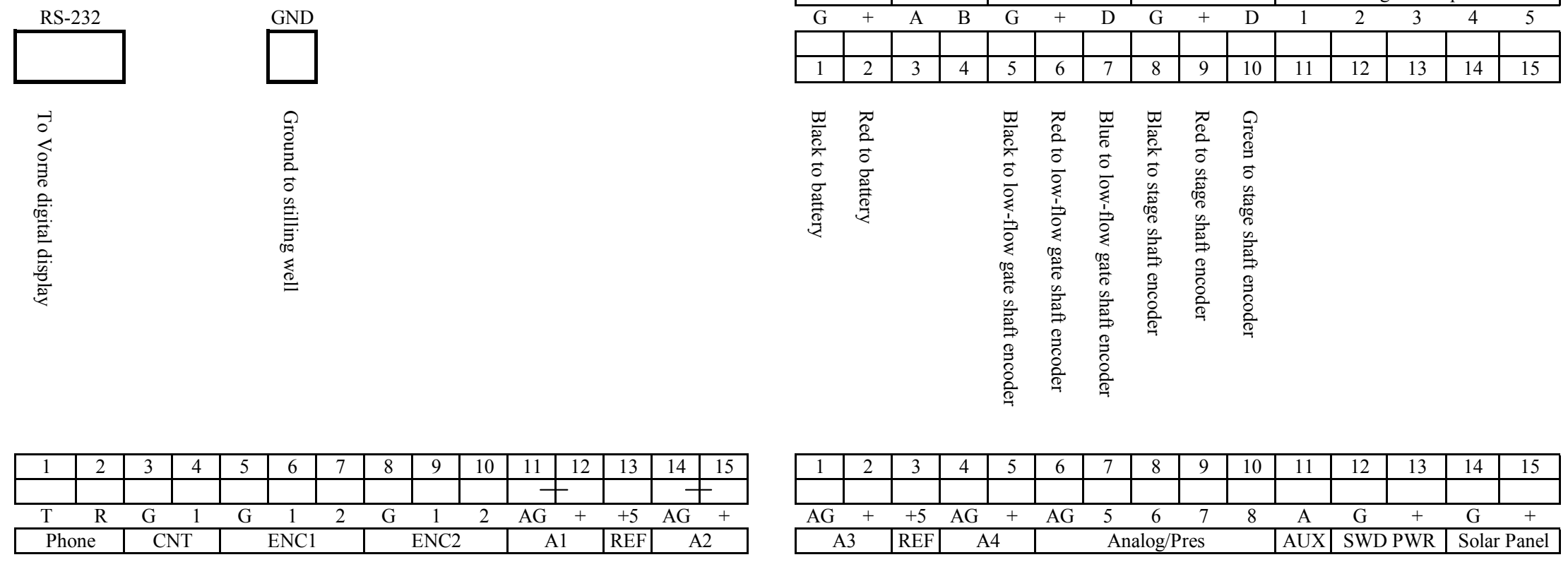

\begin{tabular}{|c|c|c|c|c|c|c|c|c|c|c|c|c|c|c|}
\hline \multicolumn{2}{|c|}{ Ext Batt } & \multicolumn{2}{|c|}{ RS485 } & \multicolumn{3}{|c|}{ SDI-12 } & \multicolumn{3}{|c|}{ SDI-12 } & \multicolumn{5}{|c|}{ Digital Output } \\
\hline $\mathrm{G}$ & + & $\mathrm{A}$ & $\mathrm{B}$ & $\mathrm{G}$ & + & $\mathrm{D}$ & $\mathrm{G}$ & + & $\mathrm{D}$ & 1 & 2 & 3 & 4 & 5 \\
\hline & & & & & & & & & & & & & & \\
\hline 1 & 2 & 3 & 4 & 5 & 6 & 7 & 8 & 9 & 10 & 11 & 12 & 13 & 14 & 15 \\
\hline
\end{tabular}

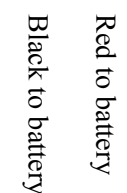

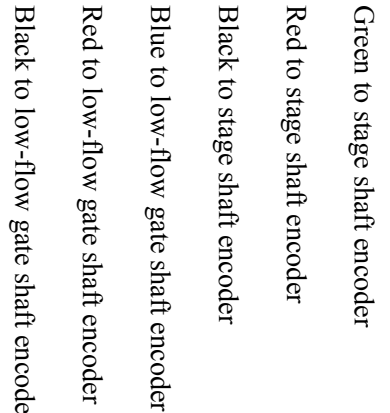
\begin{tabular}{l|l|l|l}
\hline & REF & A4 & Analog/Pres \\
\hline
\end{tabular}

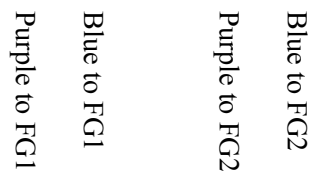

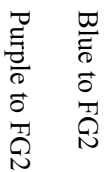

Note: Low-low gate is LOW FLOW in Sutron setup file.

FG1, Floodgate No. 1 or ANALOG1 (Sutron setup file name).

FG2, Floodgate No. 2 or ANALOG2 (Sutron setup file name).

4 denotes a resistor between the two ports of the Sutron. 
Figure 47. Joe Pool Lake equipment wiring diagram.
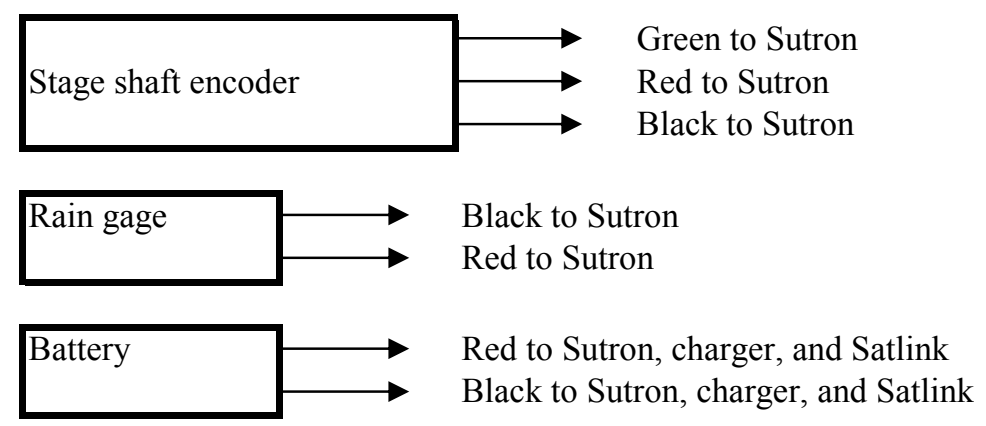

Battery
charger
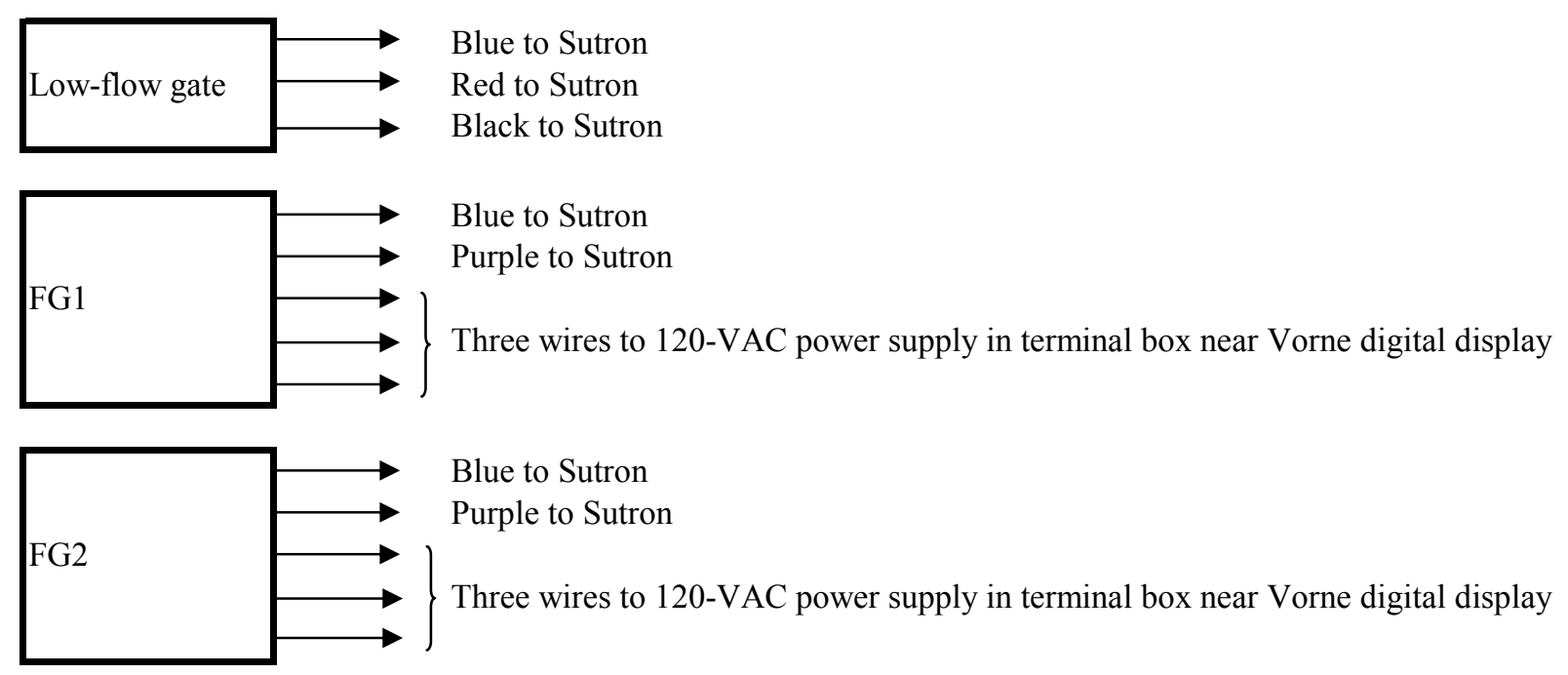

Note: $\quad$ Low-flow gate is LOW FLOW in Sutron setup file.

FG1, Floodgate No. 1 or ANALOG1 (Sutron setup file name).

FG2, Floodgate No. 2 or ANALOG2 (Sutron setup file name). 


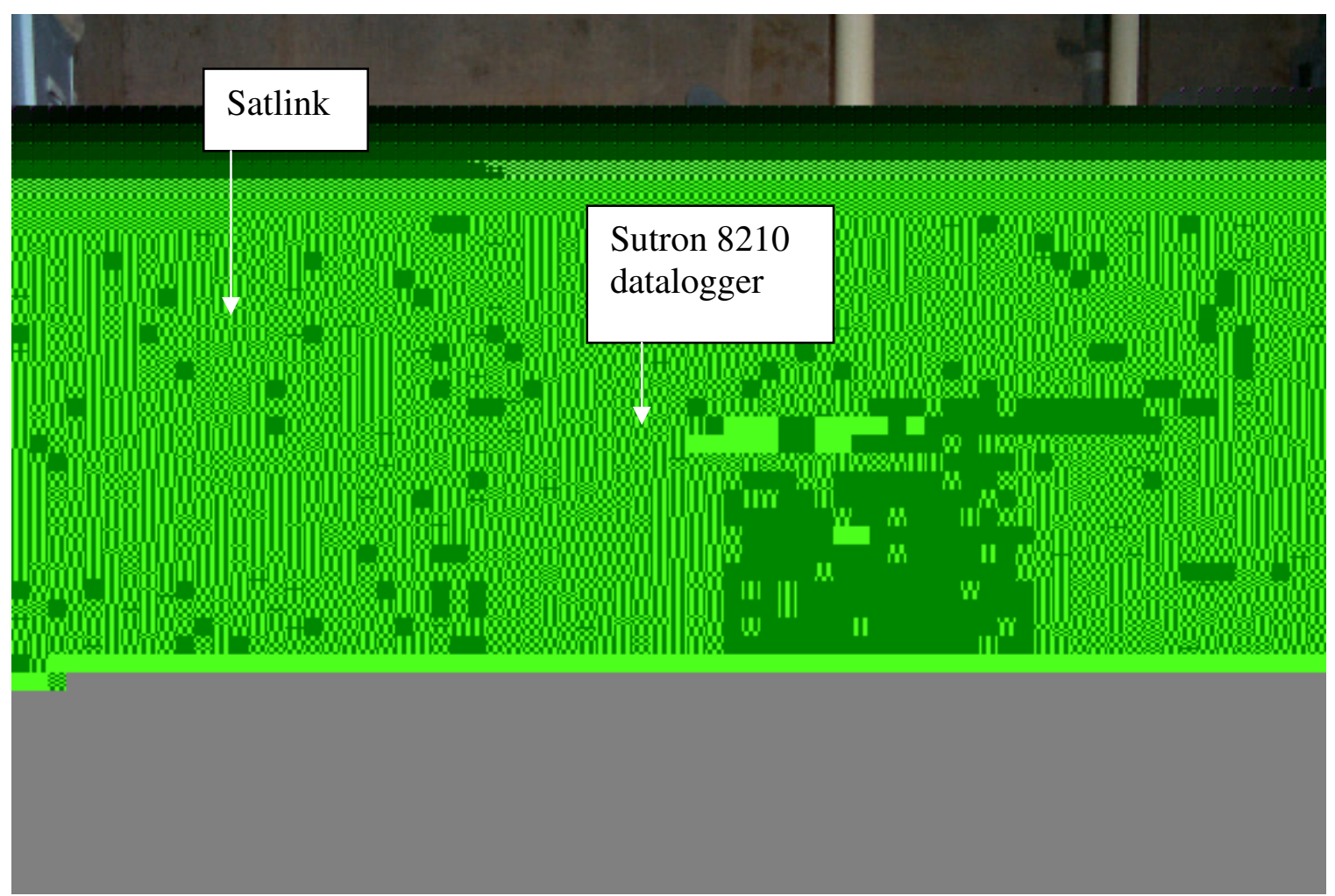

Figure 48. Sutron 8210 datalogger and Satlink at Joe Pool Lake.

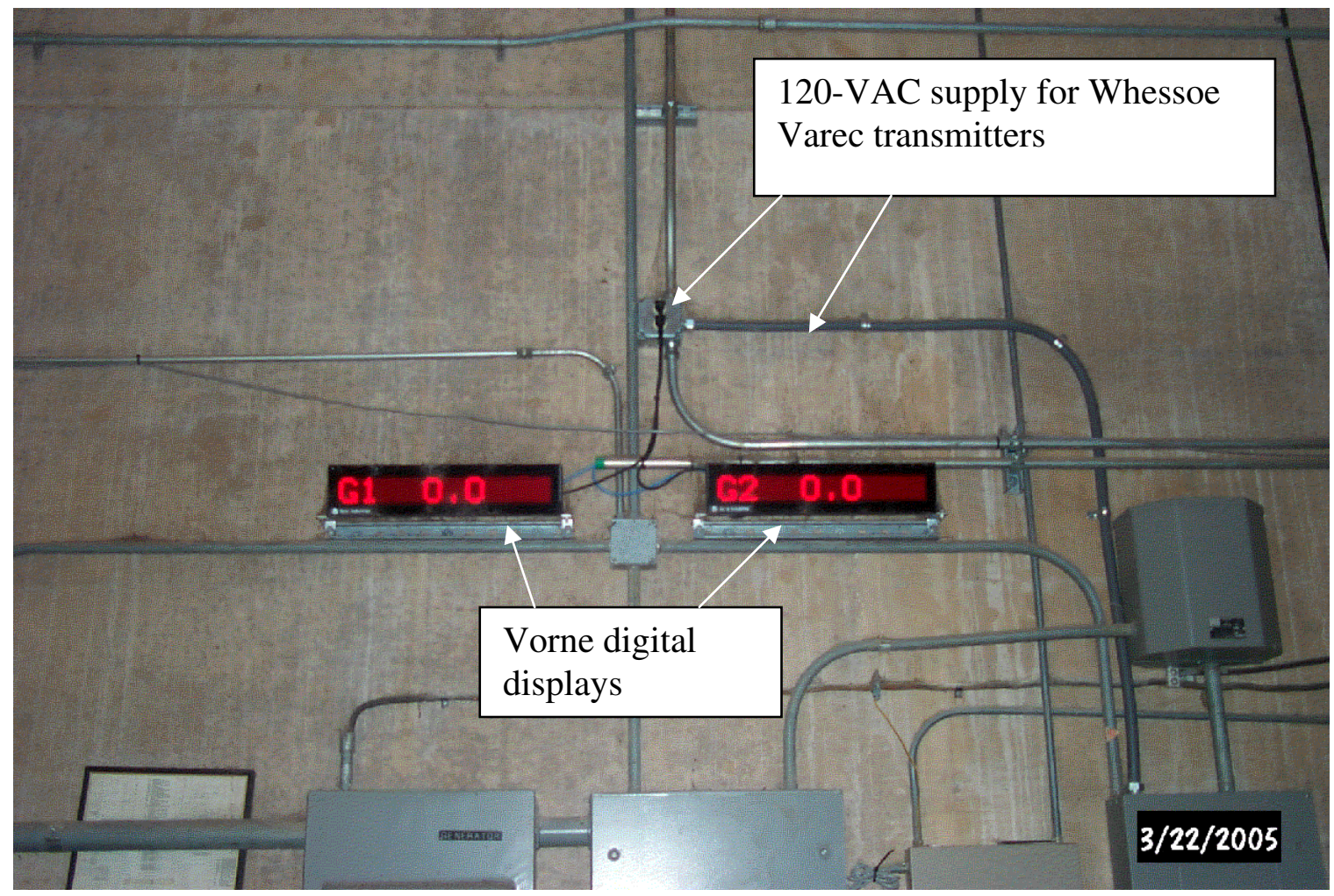

Figure 49. Digital displays and electricity supply at Joe Pool Lake. 


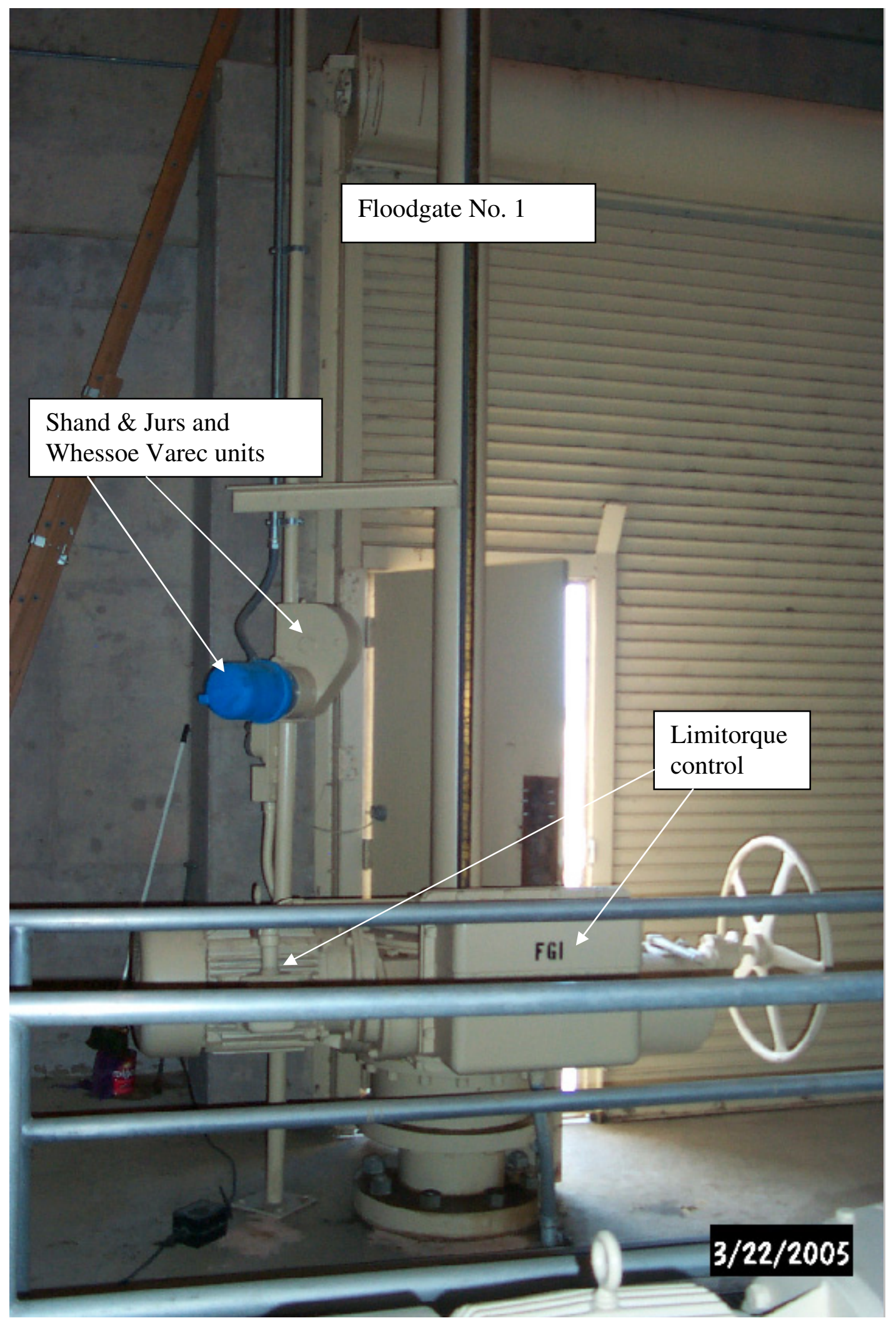

Figure 50. Gate-sensing equipment at Joe Pool Lake. 


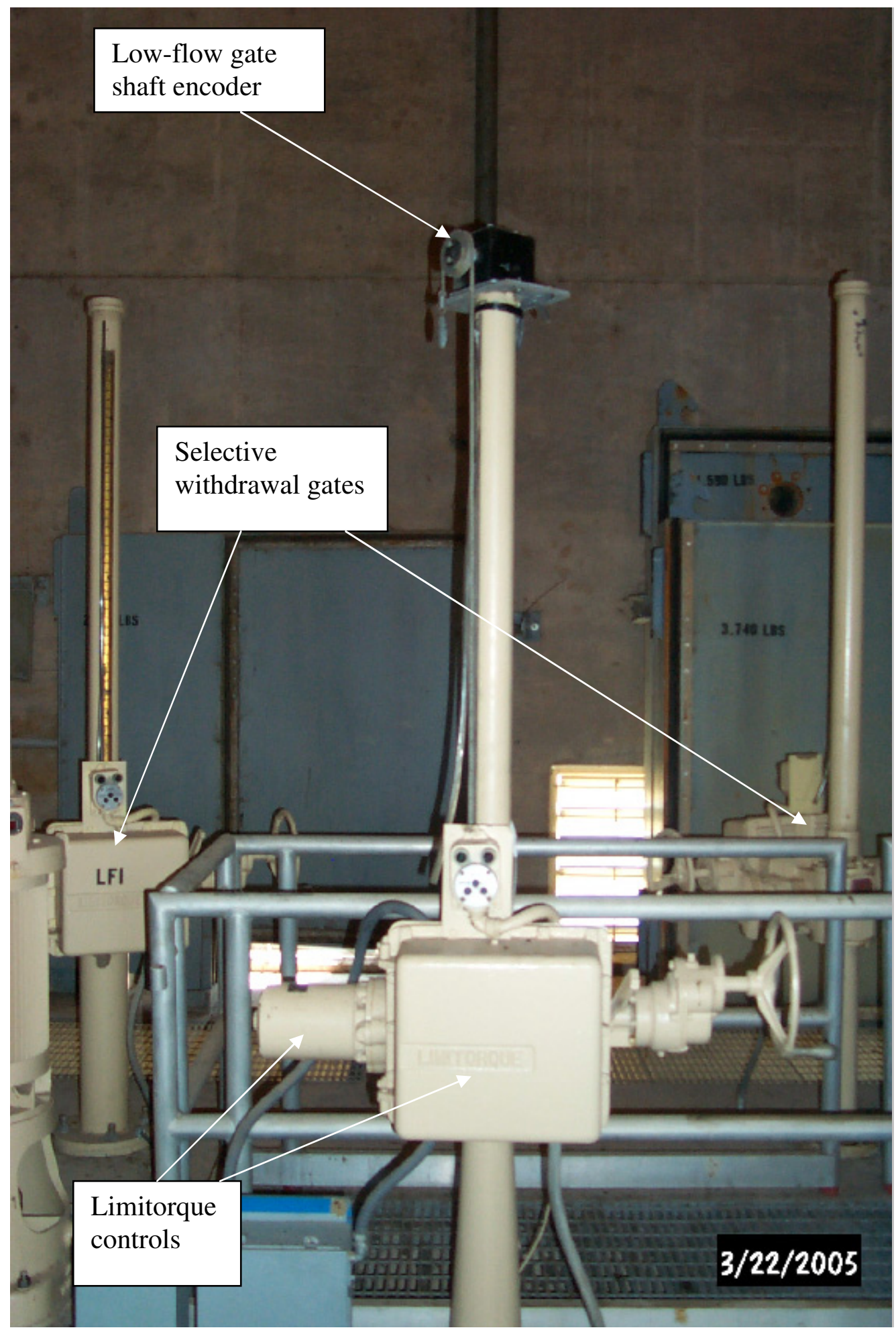

Figure 51. Low-flow gate and withdrawal gates at Joe Pool Lake. 


\section{Joe Pool Lake Sutron 8210 Setup File (JPLK.SET)}

; 8210/8200 ASCII setup file, can be converted back to a .SET file with WSETMGR.EXE

;

; MAIN SETUP

;

Setup_Version $=$ V6X

Unit_ID=JPLK

Measurement_Interval=00:15:00

Sampling_Interval=00:00:00

Measurement_Time $=00: 00: 00$

Sampling_Time $=00: 00: 00$

Switched_Power_Time $=00: 00: 00$

Samples_to_Average $=10$

Measurements_per_Log=1

Switched_Power_Mode $=\mathrm{ON}$

Recording $=\mathrm{ON}$

Basic_Run_Interval $=00: 00: 02$

Basic_Run_Time $=00: 00: 00$

Password=

Number_Resets $=18$

Log_Size $=124928$

Rom_Checksum=57134

;

; EEROM SETUP

;

Serial_Port_Mode=USER

User_Baud_Rate $=9600$

Radio_Baud_Rate $=9600$

Com_Baud_Rate $=9600$

Transfer_Baud_Rate $=9600$

SDI_Baud_Rate $=1200$

Enter_Key_Reqd=ON

Log_Dump_Mode=ALL-BIN

User_Time_Limit $=600$

Power_Delay $=1$

Analog_Delay $=5$

Pressure_Delay $=5$

Auto_Startup_Keys=SSDDDDDDRRDDPPPDPPPDDD

Time_Format=NORMAL

Date_Format=MDY

Term_Xmit_Delay $=0$

Basic_Size $=8$

Amp_Gain=1.0

;

; PROTOCOL SETUP

Master_Name $=$

Carrier_Delay $=7$

Com_Port_Mode=

Reply_Delay $=0$

Ack_Delay $=100$ 


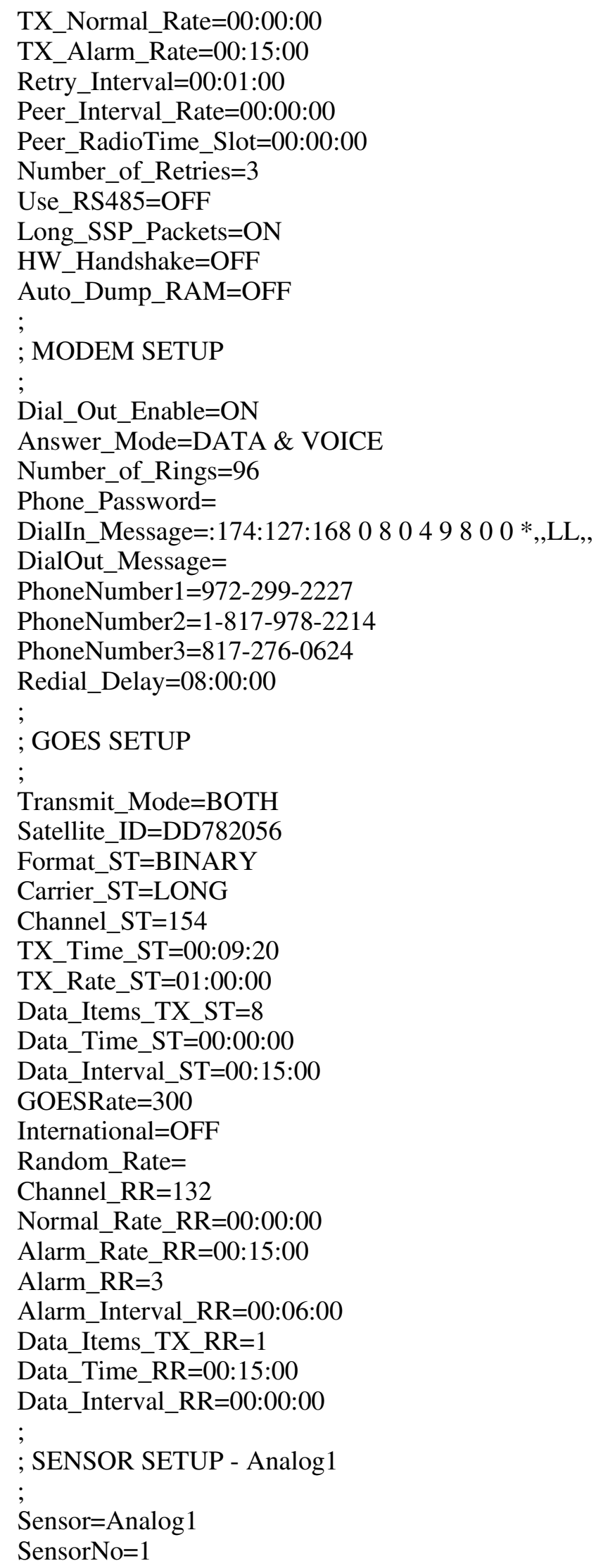




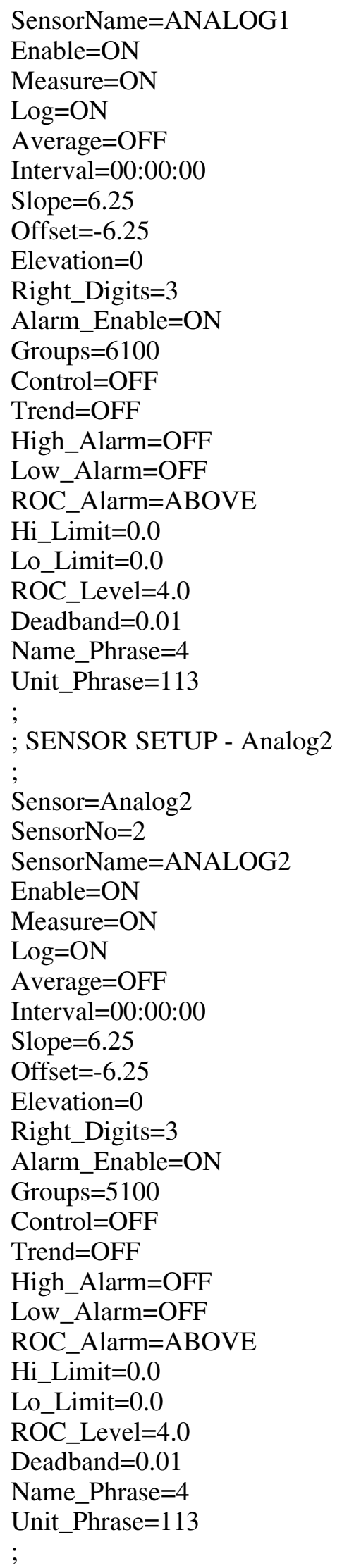




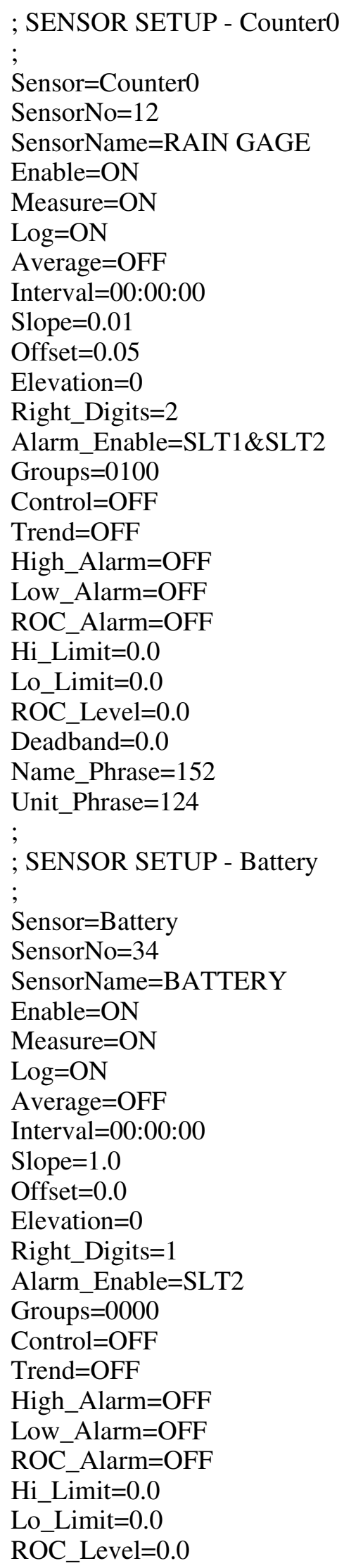




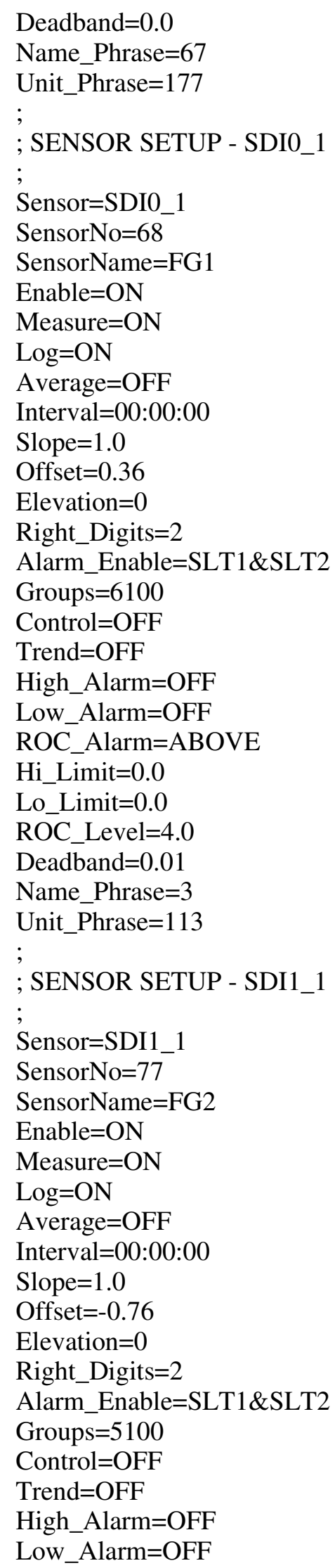




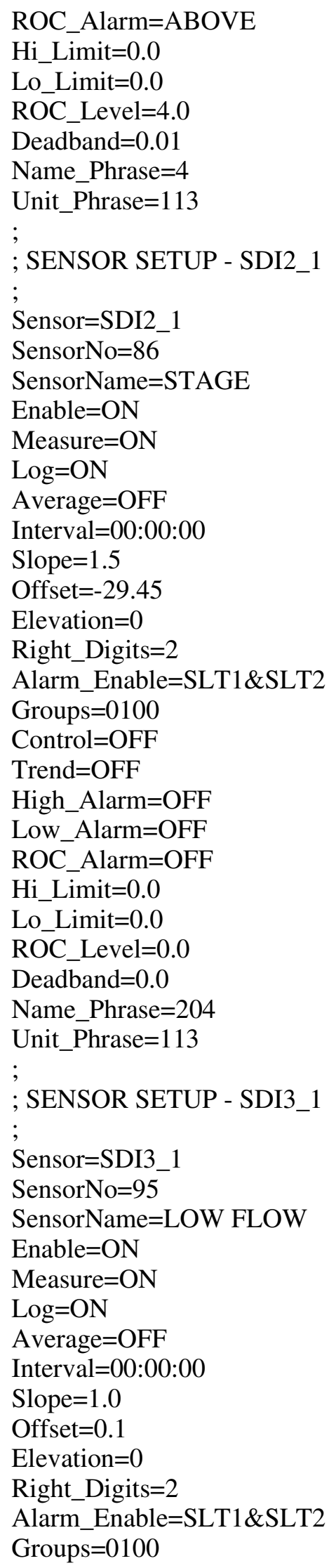




\author{
Control=OFF \\ Trend=OFF \\ High_Alarm=ABOVE \\ Low_Alarm=OFF \\ ROC_Alarm $=$ OFF \\ Hi_Limit $=1.0$ \\ Lo_Limit $=0.0$ \\ ROC_Level $=0.0$ \\ Deadband $=0.0$ \\ Name_Phrase $=133$ \\ Unit_Phrase $=0$
}

\title{
Joe Pool Lake Sutron 8210 Basic Program (JPLK.BAS)
}

5 ' COE Ft Worth Dam Automation joe pool

$10 \mathrm{a}=$ Measure $(\operatorname{analog} 1)$

$20 \mathrm{~b}=$ Measure $(\operatorname{analog} 2)$

30 ' $\mathrm{c}=$ Measure(SDI0_3)

40 ' d = Measure(SDI0_4)

50 Open "TERM:" nowait

60 Control 1,2

70 Control 11, 9600

80 Print $27 \$ ; 48 \$ 49 \$ ;$

90 Print "G1 ";:PRINT A!2!1

100 Print $27 \$ ; 48 ; 50 \$ ;$

110 Print "G2 ";:PRINT B!2!1

120 ' Print 27\$;48\$; $\$$;

130 ' Print "G3 ";:PRINT C!2!2

140 ' Print 27\$;48;52\$;

150 ' Print "G4 ";:PRINT D!2!2

160 control 2 : close

$162 \log$ time,FG1,a:log time,FG2,b

164 LOG TIME,SE_STAGE,STAGE:LOG TIME,LOW_FLOW,LOW

170 Stop 


\section{Lake O' the Pines Near Jefferson, Tex.}

\section{Location}

Lat 3245'18", long 94²9'57", Marion County, on Big Cypress Creek, $9.0 \mathrm{mi}$ west of Jefferson, and 80.1 mi upstream from mouth.

\section{Road Log}

From USGS Texas WSC-Fort Worth, take I-20 east to US 59 in Marshall, approximately $140 \mathrm{mi}$. Travel north on US 59 to SH 49 in Jefferson, approximately 18 mi. Turn left and travel west on SH 49 to FM 729, approximately 8 mi. Turn left onto FM 729 and travel west to FM 726, approximately 5 mi. Turn left onto FM 726 and travel about 3 mi to dam on Lake O' the Pines. The USACE office is on FM 726 and adjacent to the intake structure.

\section{Access}

Before visiting the site, call the Lake O' the Pines USACE office at 903-665-2336 to let them know you will be servicing the site. USACE staff will provide access to the intake structure. The door to the intake structure has an alarm.

\section{Equipment Description}

Refer to table 10, "Lake O' the Pines equipment inventory," for a complete list of equipment and to figures 52-56 for equipment wiring diagrams and photographs of equipment. Two main gates (Floodgates No. 1 and No. 2) are raised and lowered by electric motors and cables. Floodgate No. 1 is on the right side of the intake structure (facing upstream) and Floodgate No. 2 is on the left.

Each gate has a Celesco VLS9600 series cable-extension transducer and a Schmitz Engineering 24MT series position transmitter, or shaft encoder, that measures the position of the gates. As a gate moves up and down, a stainless steel cable attached to the top of the gate is wound and unwound around a precisely machined, constantdiameter cylindrical spool. The cable is wrapped around the cylinder with a traversing cable guide to create a single layer of wire, thereby preventing inaccuracies associated with a changing spool diameter. The spool is attached to a shaft coupled with a shaft encoder that measures the amount of linear displacement. The VLS9600 cable-extension position transducer is actually a PT9600 instrument with a VLS (velocity limiting system) attached as an option. The VLS system limits cable retraction rates to a safe speed to prevent damage caused by accidental free release. The amount of cable on the spool is 1,500 in., or $125 \mathrm{ft}$.

The positions of the two floodgates are displayed on Vorne digital displays on the wall to the left of the entrance to the intake structure. Gate No. 1 is posted on the left display and Gate No. 2 is on the right. On the displays Floodgates No. 1 and No. 2 are G1 and G2, respectively. For both gates, dials to indicate gate position are located on the spools on which the cables are wound and unwound to raise and lower the gates. Sometimes the dials do not function properly. They can malfunction (read incorrectly) 
because the dials turn as the spools turn and not necessarily when the gates are moving. The gates do not begin to move until all slack is out of the cables; however, the dials move as slack is taken out of the cables. Be careful using the dials as reference for the two floodgates. The Celesco units and the Schmitz shaft encoders are assumed to measure the true position of the gates because the wires attached to the top of the gates do not move until the gates themselves move.

The Sutron 8210 datalogger is powered by a 12-VDC battery, which is charged by an automatic sealed lead-acid battery charger connected to a $120-\mathrm{VAC}$ wall outlet. The position transmitters are powered by the Sutron 8210 datalogger through the 12-VDC port (labeled +) on the terminal strip of the Sutron 8210. A 120-VAC wall outlet powers the digital display.

The setup file (JFST2.SET) and a basic program file (JFST2.BAS) for the datalogger are stored on the RAM card that is kept inside the Sutron equipment box. The basic program enables transmission of gate positions from the Sutron datalogger to the Vorne digital displays. A hard copy of the setup file and the basic program file is also kept in the station folder.

The positions of Floodgates No. 1 and No. 2 are transmitted by satellite and posted on the USACE Web site (http://www.swf-wc.usace.army.mil) under Daily Reports/Gate Sensor Report. The USACE reports hourly data; however, the Sutron datalogger measures and records the gate position for the two gates every 15 minutes.

Floodgates No. 1 and No. 2 are FG1 and FG2, respectively, in the Sutron datalogger setup file and basic program file.

\section{Operation and Maintenance}

Operation and maintenance information for the equipment at Lake $\mathrm{O}$ ' the Pines Dam includes descriptions of different procedures required to maintain equipment such as routine inspections, recalibration of Floodgates No. 1 and No. 2, and annual inspections. The purpose of a site visit and the actions taken should be documented in the logbook kept near the datalogger. Include the date, time, actions, and personnel conducting the site visit in the logbook. This section lists some of the potential problems that might occur with the equipment in service and possible solutions to the problems. Refer to the Operations Manuals for the individual pieces of equipment when further detail is required. The information included here is basic operations and maintenance information.

For each visit to the site, personnel should carry all of the necessary tools required to service the equipment. The tools required to perform all of the tasks listed include the following:

- Screwdrivers, flat and Phillips head

- Allen wrenches, 5/32- and 7/64-in.

- Crescent wrench, 10-in.

- Stepladder, 10-ft

- Electrical tape

- Digital multimeter

- Pliers

- Ruler 
- Laptop computer capable of connecting (with RS-232 port and 9-pin cable) to Sutron 8210

- Sutron 8210 Operations Manual

- Battery load tester

- Spare battery

- Flashlight

- Silicone sealant

\section{Procedures during a routine inspection}

- Check the enclosure to the Sutron 8210 datalogger for damage and moisture. If moisture is entering the enclosure, seal any openings with silicone.

- Scroll through the VIEW DATA/LIVE READINGS menu and check that the datalogger is making measurements.

- Check the antenna and make sure connections are secure and waterproofed. Replace electrical tape around connections if old and brittle.

- Check the battery voltage under the LIVE READINGS menu on the Sutron 8210.

- If voltage is low (less than $11.5 \mathrm{~V}$ ), test the battery with a load tester and make sure the voltage remains above the recommended voltage specific to the load tester being used. Replace battery as needed.

- Check the Vorne digital displays and verify that the displays are reporting the same gate positions as the Sutron 8210 and that display digits are illuminated.

- Verify Floodgates No. 1 and No. 2 position sensors and transmitters are functioning properly by pulling down on the Celesco steel wire a known distance and checking the reading on the display. Hold a ruler flush with the bottom of the Celesco unit. Pull the wire down $1 \mathrm{ft}$ and verify that the Vorne display reads $1 \mathrm{ft}$ less than the current reading. If the actual amount of displacement and the measured amount do not agree, make a note of the difference. Make sure the difference is not caused by inaccuracies associated with trying to pull the wire down a known distance. According to the manufacturer, at $1 \mathrm{ft}$ of displacement the unit is accurate to within $0.0004 \mathrm{ft}$. Do not try to force agreement between the displaced amount and the measured amount by adjusting the slope or the offset in the Sutron 8210 setup. However, check that the slope is set properly to 1.0511 for both shaft encoders and adjust if set incorrectly (see "Procedures to Recalibrate Floodgates No. 1 and No. 2"). Check that the connections between the shaft encoders and the Celesco position sensors are good by making sure the Allen screws that connect the two are not loose. Open the cover on the position sensor where the wire enters the unit. Visually check that the wire appears to be winding up uniformly across the wheel and that no kinks are present. Do not try to remove the cylinder that holds the wire. If the wire is pulled down and the shaft encoder does not respond at all (no change in position), check that the SDI12 addresses are set correctly in the Sutron 8210 setup. Floodgates No. 1 and No. 2 should have addresses 1 and 2, respectively. If the slopes are set correctly, the connections and wire appear good, the shaft encoders are responding, and the SDI12 addresses are set correctly, then the shaft encoders or the Celesco position sensors need to be replaced or serviced. Try removing the shaft encoder first and testing it with another Celesco unit known to function 
properly to try to isolate the problem. If the shaft encoder is good, the Celesco unit should probably be removed and serviced. This will have to be done during an annual inspection. Refer to the "Manufacturer Contact Information" section for address and phone number.

- Whenever a change is made to the setup file or the basic program in the datalogger, download the new files to the RAM card kept at the site. To do this, insert the RAM card into the socket and turn on the 8210. Scroll down to the DUMP DATA menu. Press the right arrow once and then press the down arrow until WRITE CARD SETUP is displayed. Press the SET button and wait for the files to be transferred from the datalogger to the RAM card. Note that when doing this both the setup file and the basic program get transferred to the RAM card. To transfer the files from the RAM card to the datalogger, scroll down to the DUMP DATA menu. Press the right arrow once, then press the down arrow until READ CARD SETUP is displayed. Press the right arrow to access the setup file and the basic program. Press the down arrow to select which file to transfer to the datalogger. Transfer the selected file to the datalogger by pressing the SET button. Transfer both the setup file and the basic program.

- Before leaving the site, make sure the Sutron 8210 is reading ON \& TX under RECORDING.

\section{Procedures to recalibrate Floodgates No. 1 and No. 2}

- First make sure that the slope of the shaft encoders is set to 1.0511, as one revolution of the Celesco is 12.613 in. With the gates closed, set the instruments to read zero by adjusting the offset of the Schmitz Engineering shaft encoders.

- To change the offset or the slope, turn on the Sutron 8210 and press the down arrow to SYSTEM SETUP. Press the right arrow once and the down arrow twice to CONFIG SENSORS. Then press the right arrow once and the down arrow to select either FG1 or FG2. With the correct shaft encoder selected, press the right arrow once and then the down arrow to slope and offset. Press the SET button once when either slope or offset are highlighted. Change the value using the arrow buttons. Right and left arrow buttons move from one digit to the next. Up and down arrow buttons increase or decrease the value, respectively. When finished, press the SET button to save the new value. Check LIVE READINGS or the digital display to see the new measured value.

- Record changes to the slope or the offset in the logbook and save the new setup file to the RAM card.

\section{Procedures during an annual inspection}

- During an inspection the emergency bulkheads are lowered, and the floodgates are raised all the way up into the intake structure where they are cleaned and inspected. As the gates are raised, check and clean the wire as it winds up into the Celesco position sensor. Check the wire for worn areas and clean debris off the wire. If the wire appears substantially damaged do not try to replace the wire. Send the unit to Celesco for service. Refer to the "Manufacturer Contact Information" section for address and phone number. 
- When the gates are lowered and closed after being serviced, check that the shaft encoders and datalogger measure zero. If not, follow the instructions to recalibrate the instruments.

- After the inspection, follow all of the procedures during a routine inspection. 
Table 10. Lake O' the Pines equipment inventory.

[See table of contents for abbreviated units; --, not available or not applicable]

\begin{tabular}{|c|c|c|c|c|}
\hline $\begin{array}{c}\text { Item } \\
\text { no. }\end{array}$ & Item description & Manufacturer & Model no. & Remarks \\
\hline 1. & Floodgate No. 1 position sensor & Celesco & VLS9600-1500-114-SCH-24MTF & $\begin{array}{l}\text { Gate is FG1 in Sutron setup; equipment } \\
\text { is not labeled }\end{array}$ \\
\hline 2. & $\begin{array}{l}\text { Floodgate No. } 1 \text { position } \\
\text { transmitter }\end{array}$ & $\begin{array}{l}\text { Schmitz } \\
\text { Engineering }\end{array}$ & $\begin{array}{l}\text { 24MT-256-4096-SDI12-CR6- } \\
\text { 375/879-SUT }\end{array}$ & Shaft encoder with SDI12 address 1 \\
\hline 3. & $\begin{array}{l}\text { Wire for position transmitter } \\
\text { No. } 1\end{array}$ & -- & -- & $\begin{array}{l}68 \mathrm{ft} \text { of } 24 \mathrm{AWG} / 8 \text { wires (only } 6 \text { wires } \\
\text { needed) from transmitter to Sutron } 8210\end{array}$ \\
\hline 4. & Floodgate No. 2 position sensor & Celesco & VLS9600-1500-114-SCH-24MTF & $\begin{array}{l}\text { Gate is FG2 in Sutron setup; equipment } \\
\text { is not labeled }\end{array}$ \\
\hline 5 . & $\begin{array}{l}\text { Floodgate No. } 2 \text { position } \\
\text { transmitter }\end{array}$ & $\begin{array}{l}\text { Schmitz } \\
\text { Engineering }\end{array}$ & $\begin{array}{l}\text { 24MT-256-4096-SDI12-CR6- } \\
\text { 375/879-SUT }\end{array}$ & Shaft encoder with SDI12 address 2 \\
\hline 6. & $\begin{array}{l}\text { Wire for position transmitter } \\
\text { No. } 2\end{array}$ & -- & -- & $\begin{array}{l}45 \mathrm{ft} \text { of } 24 \mathrm{AWG} / 8 \text { wires (only } 6 \text { wires } \\
\text { needed) from transmitter to Sutron } 8210\end{array}$ \\
\hline 7. & Rain gage & -- & -- & Instrument is not labeled \\
\hline 8. & Datalogger & Sutron & 8210 & -- \\
\hline 9 . & $\begin{array}{l}\text { Digital displays for Floodgates } \\
\text { No. } 1 \text { and No. } 2\end{array}$ & Vorne Industries & GY2200 & $\begin{array}{l}\text { Connected to Sutron } 8210 \text { through RS- } \\
2329 \text {-pin cable }(25 \mathrm{ft}) \text { and powered by } \\
120 \text {-VAC wall outlet }\end{array}$ \\
\hline 10. & Battery & Power Sonic & PS-12550U & $12-\mathrm{V}, 55.0-\mathrm{A}-\mathrm{h}$ battery for Sutron 8210 \\
\hline 11. & Battery charger & Power Sonic & PSC-12800A & $12-\mathrm{V}, 800-\mathrm{mA}$ \\
\hline 12. & Antenna & Sutron & YAGI & Mounted on side of intake structure \\
\hline 13. & Antenna cable & Alpha Wire-J & PN 9008 RG 8/U & 10 -ft cable from Sutron 8210 to antenna \\
\hline 14. & Antenna polyphaser & Polyphaser & IS-50NX-C1 & -- \\
\hline
\end{tabular}




\section{Job Hazard Analysis}

Required protective clothing, Safety Equipment, and supplies: Personal flotation device (PFD), reflective vest, gloves, steel-toed shoes, waders, cell phone, first aid kit, fire extinguisher, rotating or strobe type emergency lights, drinking water.

\begin{tabular}{|c|c|c|}
\hline $\begin{array}{l}\text { Sequence of basic } \\
\text { job steps }\end{array}$ & $\begin{array}{l}\text { Potential } \\
\text { accident or hazard }\end{array}$ & Recommended safe job procedures \\
\hline $\begin{array}{l}\text { Upon job } \\
\text { assignment }\end{array}$ & $\begin{array}{l}\text { Water-related accident or } \\
\text { injury }\end{array}$ & $\begin{array}{l}\text { Employees working in and around water must receive } \\
\text { training specified in WRD Memo } 2000.10 \text {, "Policy for } \\
\text { safety training associated with over-water activities." }\end{array}$ \\
\hline $\begin{array}{l}\text { Loading and } \\
\text { unloading } \\
\text { equipment }\end{array}$ & $\begin{array}{l}\text { Pinched fingers, mashed } \\
\text { toes, or strained back }\end{array}$ & $\begin{array}{l}\text { Be aware of hand placement. Wear protective gloves and } \\
\text { steel-toed shoes. Use proper lifting techniques. Lift with } \\
\text { legs. Use extra caution lifting heavy sounding weights. }\end{array}$ \\
\hline $\begin{array}{l}\text { Driving to and } \\
\text { returning from work } \\
\text { site }\end{array}$ & $\begin{array}{l}\text { Traffic accidents, vehicle } \\
\text { flooding, or drowning }\end{array}$ & $\begin{array}{l}\text { Drivers of USGS vehicles must have Drivers Safety } \\
\text { Training (SM 445-2-H, chap. 16). Be alert to traffic in } \\
\text { area, obey all traffic laws, and reduce speed when weather } \\
\text { conditions are bad. Do not drive across flooded highways } \\
\text { unless water depth and bridge conditions are known to be } \\
\text { safe. }\end{array}$ \\
\hline Parking vehicle & $\begin{array}{l}\text { Personal and vehicle } \\
\text { safety when exiting } \\
\text { vehicle in traffic; bank } \\
\text { collapse or bridge failure }\end{array}$ & $\begin{array}{l}\text { Use rotating or strobe emergency lights, follow site } \\
\text { traffic-control plan, wear DOT Type III reflective vest } \\
\text { when working in or near roadway. Park away from stream } \\
\text { at a safe distance from banks. }\end{array}$ \\
\hline $\begin{array}{l}\text { Set up traffic- } \\
\text { control equipment }\end{array}$ & $\begin{array}{l}\text { Personal and public } \\
\text { safety }\end{array}$ & $\begin{array}{l}\text { Employees working in or near roadways must have Work } \\
\text { Zone Traffic-Control Safety Training. Remain alert to } \\
\text { traffic conditions. }\end{array}$ \\
\hline $\begin{array}{l}\text { Working at field } \\
\text { site }\end{array}$ & Drowning & $\begin{array}{l}\text { Employees are required to wear a PFD when working in, } \\
\text { on, or over any body of water. There are no exemptions } \\
\text { for employees in the Texas WSC. PFDs will be } \\
\text { international orange in color and equipped with reflective } \\
\text { tape in accordance with } 46 \text { CFR } 25.25-15 \text {. Self-inflating } \\
\text { PFDs are not to be worn by employees who have not had } \\
\text { In-Water Safety Training. }\end{array}$ \\
\hline $\begin{array}{l}\text { Working at field } \\
\text { site }\end{array}$ & Trips, slips, and falls & $\begin{array}{l}\text { Follow path clear of obstructions and with minimal slope; } \\
\text { avoid slippery surfaces. Walk cautiously on steep slopes } \\
\text { or paths with loose material. Use appropriate footwear for } \\
\text { the terrain and conditions. Follow the safest, not the } \\
\text { fastest path! }\end{array}$ \\
\hline $\begin{array}{l}\text { Working at field } \\
\text { site }\end{array}$ & $\begin{array}{l}\text { Dehydration, heat } \\
\text { exhaustion, heat stroke, } \\
\text { or sunburn }\end{array}$ & $\begin{array}{l}\text { Drink plenty of water or electrolyte drink. Wear } \\
\text { appropriate clothing. Take occasional breaks and watch } \\
\text { for symptoms of heat exhaustion. Use sun block. }\end{array}$ \\
\hline $\begin{array}{l}\text { Working at field } \\
\text { site }\end{array}$ & Hypothermia or frostbite & $\begin{array}{l}\text { Wear foul-weather gear during winter months. Keep } \\
\text { clothing dry. }\end{array}$ \\
\hline $\begin{array}{l}\text { Working at field } \\
\text { site }\end{array}$ & Snake bites & $\begin{array}{l}\text { Wear appropriate foot and leg protection. Watch path } \\
\text { ahead. Keep area around gage clear of brush. If bitten, } \\
\text { seek immediate medical help. }\end{array}$ \\
\hline
\end{tabular}




\begin{tabular}{|l|l|l|}
\hline $\begin{array}{l}\text { Working at field } \\
\text { site }\end{array}$ & Poisonous plants & $\begin{array}{l}\text { Know how to identify poisonous plants. Wear protective } \\
\text { clothing. Wash and flush exposed areas immediately with } \\
\text { cold water. Wash with degreasing type soap and flush } \\
\text { from skin. Seek medical attention for severe reactions. }\end{array}$ \\
\hline Entering gage house & $\begin{array}{l}\text { Infectious disease or } \\
\text { airborne pollutants; risk } \\
\text { of hantavirus exposure }\end{array}$ & $\begin{array}{l}\text { Watch for bats or rodent nests and droppings. If nest or } \\
\text { droppings are present, do not disturb dust. Gage should be } \\
\text { periodically cleaned to minimize risk of exposure. See } \\
\text { WRD memo dated 10/28/97, "Preventing hantavirus } \\
\text { disease," and OP memo dated 01/94, "Instructions for } \\
\text { preventing hantavirus disease." }\end{array}$ \\
\hline Entering gage house & Insect or snake bites & $\begin{array}{l}\text { Inspect in and around shelter for harmful insects. Use } \\
\text { wasp or insect spray. Inspect in and around shelter for } \\
\text { snakes prior to entry. }\end{array}$ \\
\hline
\end{tabular}

\section{Site-Specific Job Hazards}

The items listed are safety issues specific to this site that deserve special emphasis.

- Be careful removing or installing the Celesco position transmitters or the Schmitz shaft encoders on Floodgates No. 1 and No. 2. The gaps between the spools holding the cable that raises and lowers the gates are a fall hazard.

- Be careful backing out of the driveway to the intake structure. Cars travel quickly on the road over the dam, and it is difficult to back out without entering both lanes of traffic.

- The Vorne digital displays are about $12 \mathrm{ft}$ off the floor of the intake structure and therefore require a stepladder when being checked or changed out. 
Figure 52. Lake O' the Pines Sutron 8210 wiring panel.

\begin{tabular}{|c|}
\hline \\
\hline
\end{tabular}

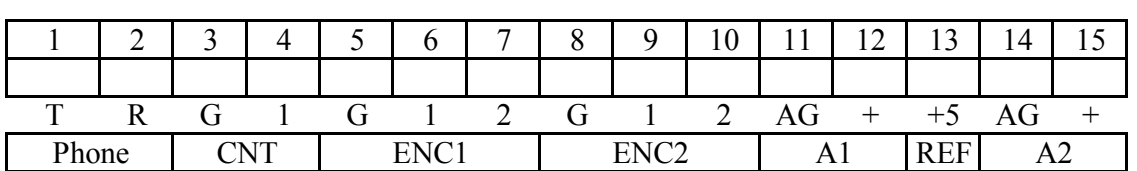

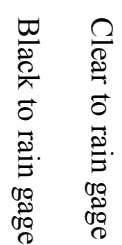

Note: FG1, Floodgate No. 1

FG2, Floodgate No. 2.

Orange wires from SDI-12 D port have faded and appear yellow.

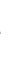

\begin{tabular}{|c|c|c|c|c|c|c|c|c|c|c|c|c|c|c|}
\hline \multicolumn{2}{|c|}{ Ext Batt } & \multicolumn{2}{|c|}{ RS485 } & \multicolumn{3}{|c|}{ SDI-12 } & \multicolumn{3}{|c|}{ SDI-12 } & \multicolumn{5}{|c|}{ Digital output } \\
\hline $\bar{G}$ & + & $\overline{\mathrm{A}}$ & $\mathrm{B}$ & $\mathrm{G}$ & + & $\bar{D}$ & $\mathrm{G}$ & + & $\mathrm{D}$ & 1 & 2 & 3 & 4 & 5 \\
\hline & & & & & & & & & & & & & & \\
\hline 1 & 2 & 3 & 4 & 5 & 6 & 7 & 8 & 9 & 10 & 11 & 12 & 13 & 14 & 15 \\
\hline
\end{tabular}

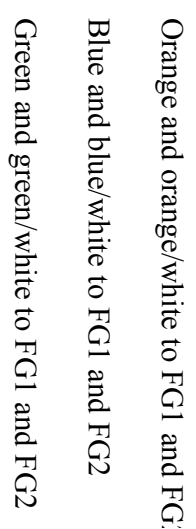

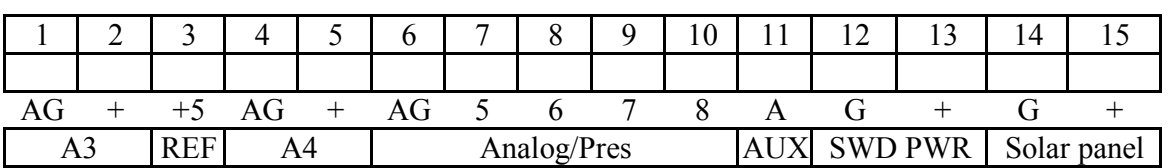

年
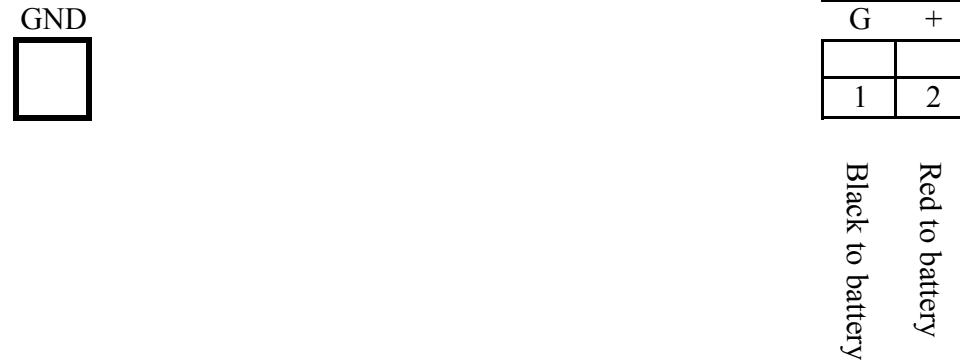

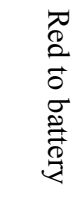


Figure 53. Lake $\mathrm{O}^{\prime}$ the Pines equipment wiring diagram.

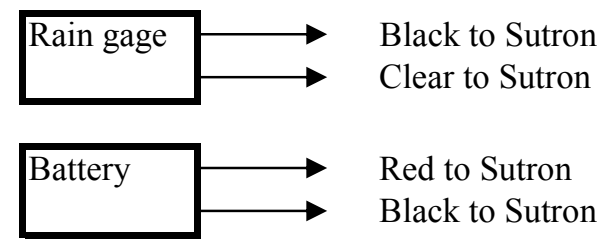

\begin{tabular}{l}
$\begin{array}{l}\text { Battery } \\
\text { charger }\end{array} \longrightarrow \quad \begin{array}{l}\text { Black with ribs to red battery terminal } \\
\text { Black to black battery terminal }\end{array}$ \\
\hline
\end{tabular}
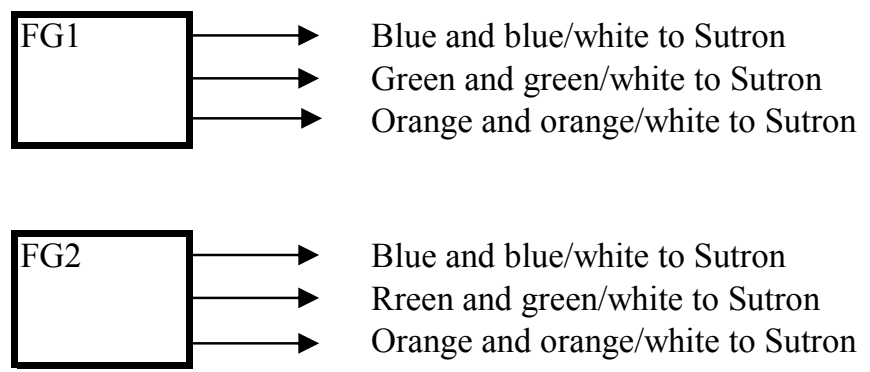

Note: $\quad$ FG1, Floodgate No. 1.

FG2, Floodgate No. 2. 


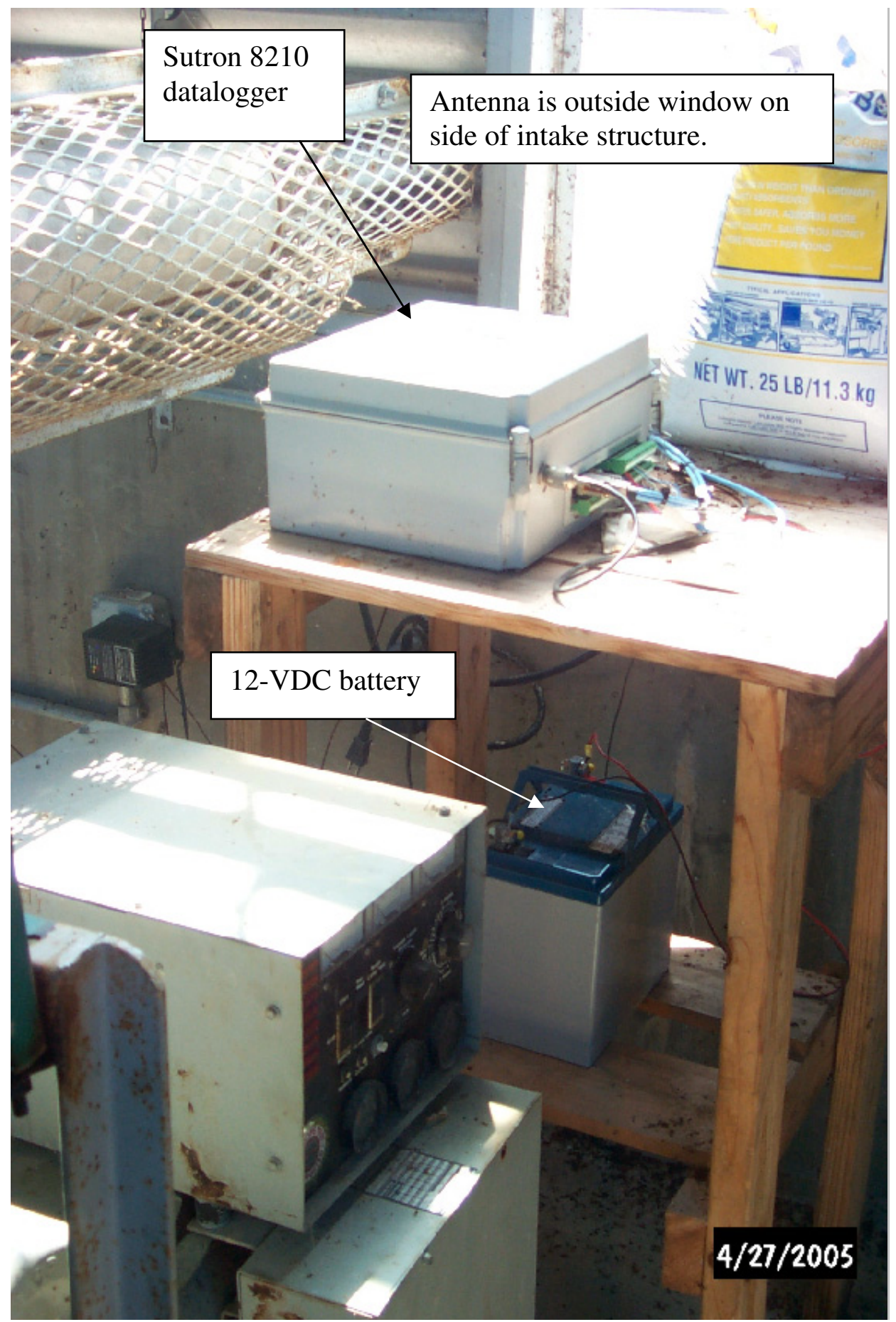

Figure 54. Sutron 8210 datalogger at Lake O’ the Pines. 


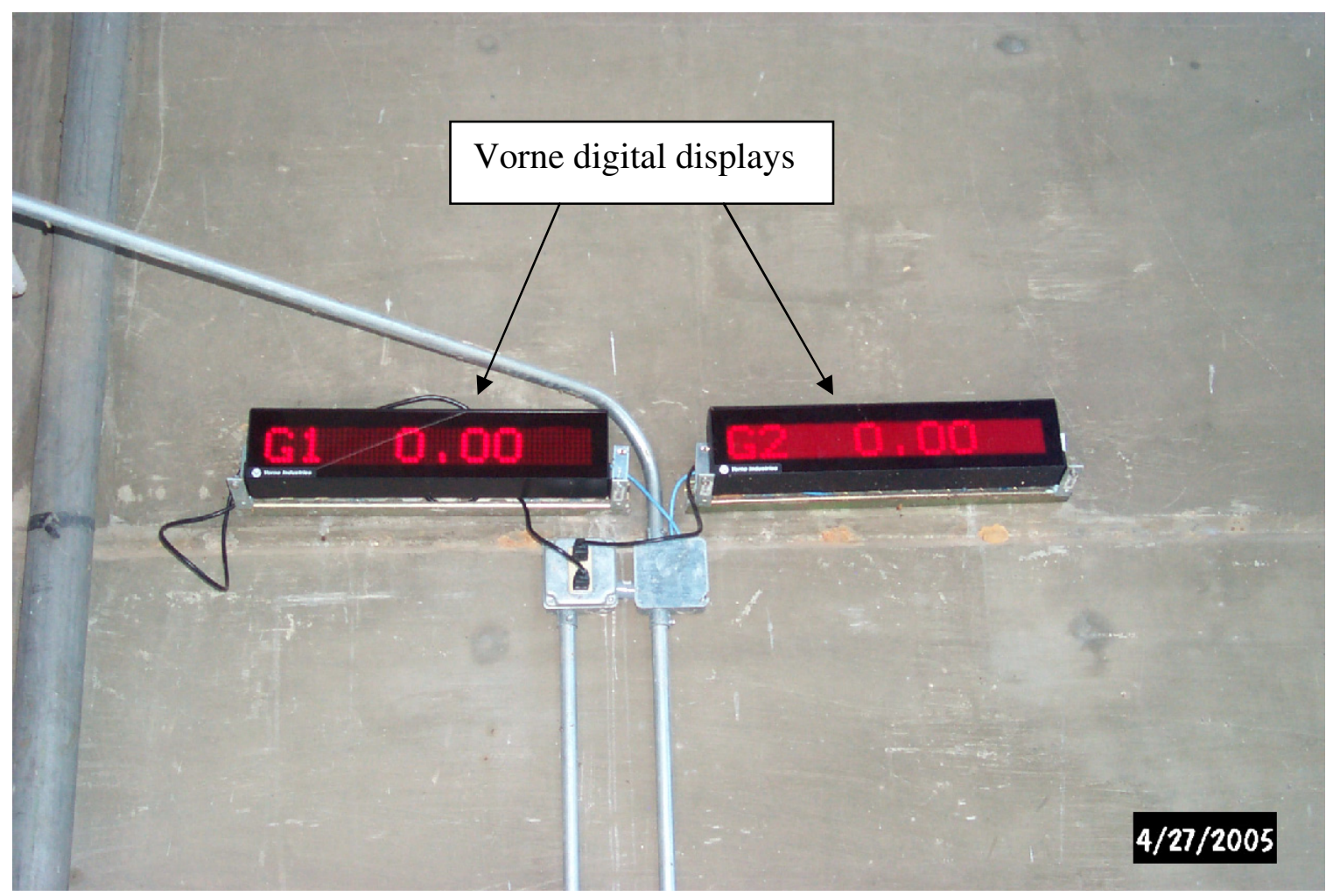

Figure 55. Digital displays at Lake O' the Pines.

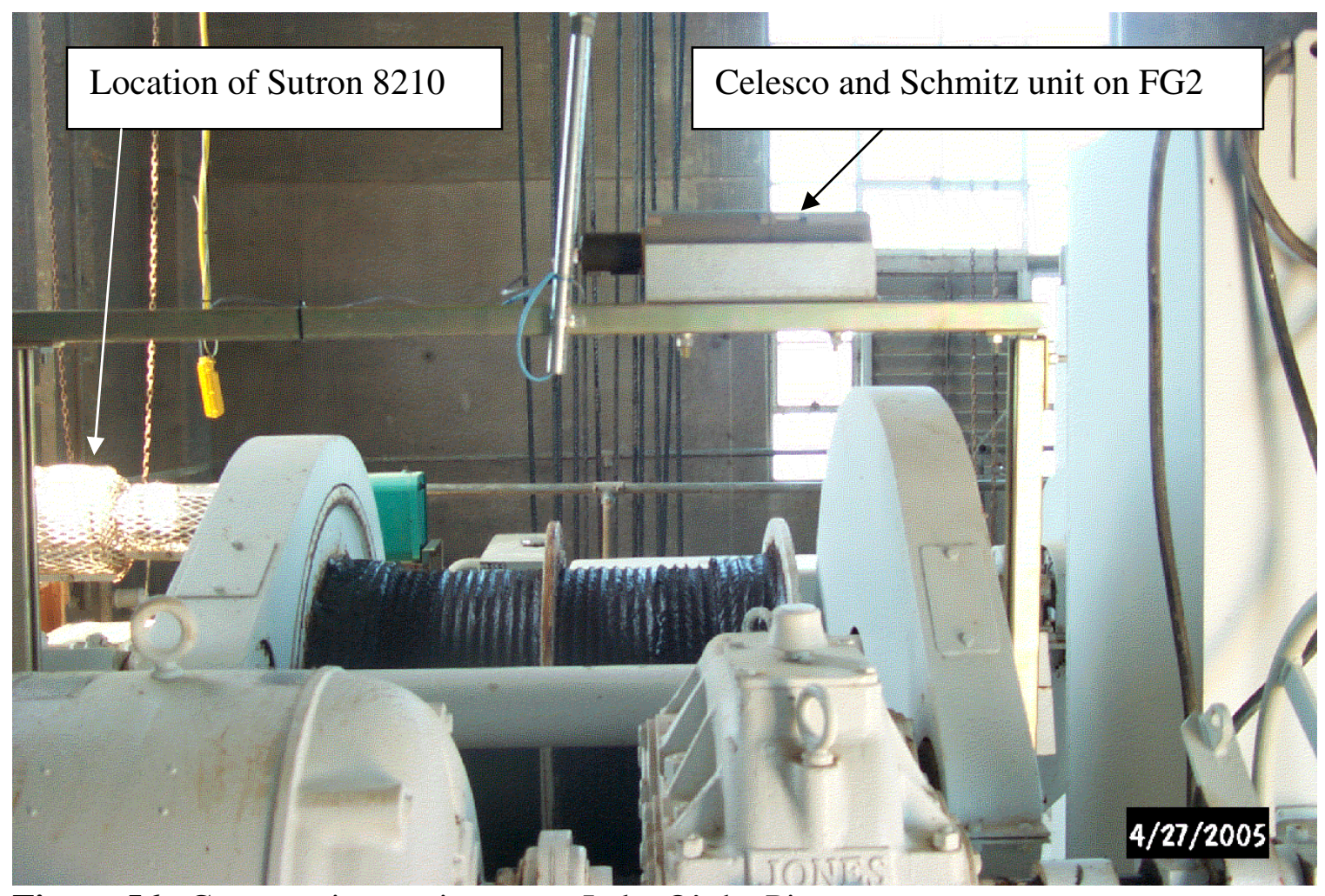

Figure 56. Gate-sensing equipment at Lake $O^{\prime}$ the Pines. 


\section{Lake O' the Pines Sutron 8210 Setup File (JFST2.SET)}

; 8210/8200 ASCII setup file, can be converted back to a .SET file with WSETMGR.EXE

;

; MAIN SETUP

;

Setup_Version $=$ V4X

Unit_ID=JFST2

Measurement_Interval=00:15:00

Sampling_Interval=00:00:00

Measurement_Time $=00: 00: 00$

Sampling_Time $=00: 00: 00$

Switched_Power_Time $=00: 00: 00$

Samples_to_Average $=10$

Measurements_per_Log $=1$

Switched_Power_Mode=OFF

Recording $=\mathrm{ON}$

Basic_Run_Interval=00:00:02

Basic_Run_Time $=00: 00: 00$

Password=

Number_Resets $=14$

Log_Size $=124928$

Rom_Checksum=10811

;

; EEROM SETUP

Serial_Port_Mode=USER

User_Baud_Rate $=9600$

Radio_Baud_Rate $=1200$

Com_Baud_Rate $=9600$

Transfer_Baud_Rate $=9600$

SDI_Baud_Rate $=1200$

Enter_Key_Reqd=OFF

Log_Dump_Mode=ALL-BIN

User_Time_Limit $=960$

Power_Delay $=1$

Analog_Delay $=5$

Pressure_Delay $=5$

Auto_Startup_Keys=SS

Time_Format=NORMAL

Date_Format=MDY

Term_Xmit_Delay $=0$

Basic_Size $=1$

Amp_Gain=1.0

;

; PROTOCOL SETUP

Master_Name $=$

Carrier_Delay $=7$

Com_Port_Mode $=$

Reply_Delay $=0$

Ack_Delay $=100$ 


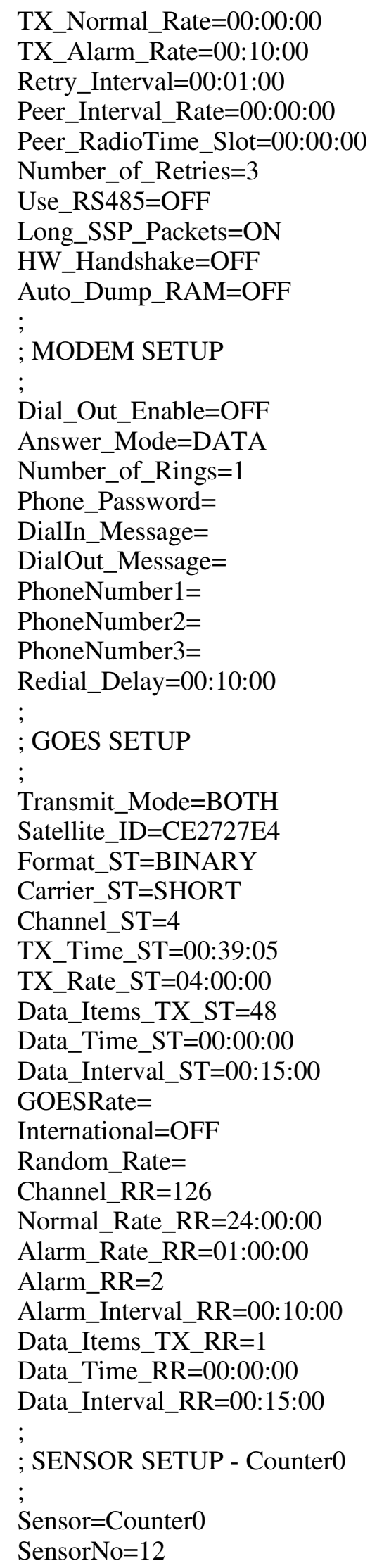




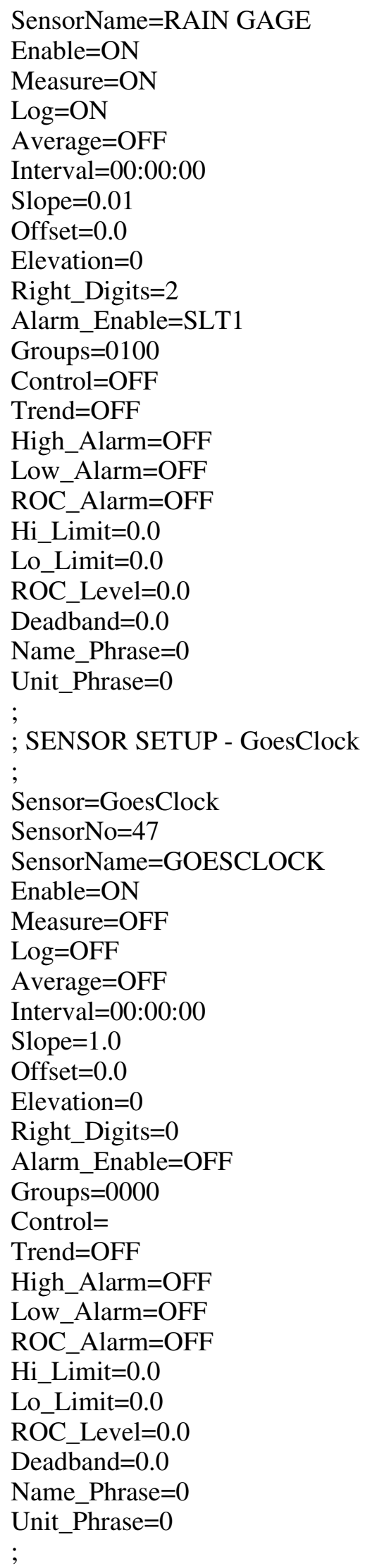




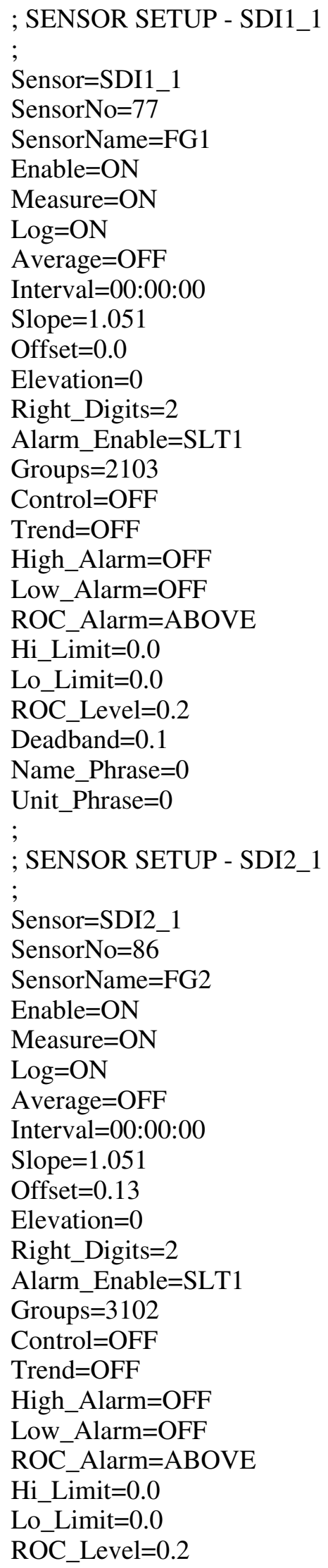


Deadband $=0.1$

Name_Phrase $=0$

Unit_Phrase $=0$

\section{Lake O' the Pines Sutron 8210 Basic Program (JFST2.BAS)}

5 ' COE Ft Worth Dam Automation Lake o the Pines

$10 \mathrm{a}=$ Measure(FG1)

$20 \mathrm{~b}=$ Measure(FG2)

30 ' $\mathrm{c}=$ Measure(SDI0_3)

40 ' d = Measure(SDI0_4)

50 Open "TERM:" nowait

60 Control 1,2

70 Control 11, 9600

80 Print $27 \$ ; 48$ \$49\$;

90 Print "G1 ";:PRINT A!2!2

100 Print $27 \$ ; 48 \$ ; 50 \$$;

110 Print "G2 ";:PRINT B!2!2

120 ' Print $27 \$ ; 48 \$ ; 51 \$$;

130 ' Print "G3 ";:PRINT C!2!2

140 ' Print $27 \$ ; 48$;52\$;

150 ' Print "G4 ";:PRINT D!2!2

160 control 2 : close

170 Stop 


\section{Ray Roberts Lake Near Pilot Point, Tex.}

\section{Location}

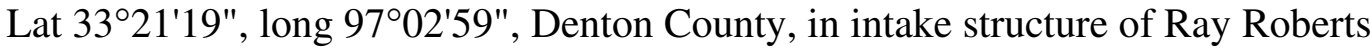
Dam on Elm Fork Trinity River, 3.7 mi upstream from Bray Branch, 5.7 mi southwest of Pilot Point, and 60.0 mi upstream from mouth.

\section{Road Log}

From USGS Texas WSC-Fort Worth, proceed north on I-35 to FM 455 in Sanger. Travel east on FM 455 approximately 8.0 mi to intake structure on Ray Roberts Dam.

\section{Access}

Before visiting the site, call the Ray Roberts Dam USACE office at 972-434-1667 to let them know you will be servicing the site. The lock on the fence to the road along the top of the dam and the lock at the intake structure both use a USACE key that is available from USGS staff at the WSC-Fort Worth. The door to the intake structure does not have an alarm.

\section{Equipment Description}

Refer to table 11, "Ray Roberts Lake equipment inventory," for a complete list of equipment and to figures 57-60 for equipment wiring diagrams and photographs of equipment. Two main floodgates are raised and lowered by hydraulic pistons. The floodgates are labeled 1 and 2 and will be referred to as Floodgates No. 1 and No. 2 in this description to be consistent with naming conventions at other dams. Floodgate No. 1 is on the left side of the intake structure (facing upstream) and Floodgate No. 2 is on the right. Note that the location of the gates is different from all other dams inspectedtypically the gate on the right is No. 1 and the gate on the left is No. 2. Both are located on the lower level of the intake structure that is accessed by descending the spiral staircase on the right side (facing upstream) of the upper deck. The low-flow gate (not labeled) is on the top deck of the intake structure between four selective withdrawal gates; a Limitorque electric valve operator raises and lowers the low-flow gate. The four selective withdrawal gates allow water to be pulled from different depths through the low-flow gate. They are labeled 1 through 4.

The gates (flood and low flow) use Shand \& Jurs 92020 automatic tank level gages to indicate the position of the gates. The floodgate positions are relayed to a Sutron 8210 datalogger with Whessoe Varec 8200 series liquid level transmitters. The low-flow gate does not have a transmitter; therefore, the position of this gate is not recorded by the datalogger.

A steel tape runs from the top of each gate to the 92020 tank level gage, where it wraps around a storage drum connected to a Neg' ator constant-force spring motor. The Neg'ator spring motor consists of a prestressed stainless steel tape that is formed into a coil and stored on a small storage drum. The free end of the coil is wrapped backwards onto a larger output drum and then fastened to the drum. When the steel tape connected 
to the top of the gate winds up in the 92020 gage as the gate is raised, the tape of the Neg'ator spring motor will wind up onto the small storage drum. Conversely, when the steel tape connected to the top of the gate unwinds as the gate is lowered, the tape of the Neg'ator spring motor will unwind from the small storage drum and wind up on the output drum. In both instances the Neg' ator spring motor functions to provide a constant amount of force (torque) on the steel tape attached to the gate regardless of the amount of deflection. The movement of the small storage drum rotates a shaft inside the 8200 position transmitter. The shaft is coupled to a worm gear, which in turn drives the shaft of a potentiometer. Rotation of the shaft causes a change in the output current of the transmitter. The variations in current output are carried to the Sutron 8210 datalogger by two wires. At the datalogger, the current is passed through a resistor so the voltage can be measured. The output current of the transmitters varies from 4 to $20 \mathrm{~mA}$.

Gate-sensing equipment serves as a reference for the two floodgates at Ray Roberts Dam. The steel tape that runs from the Shand \& Jurs gages to the gates runs alongside a ruler. A pointer is attached to the steel tape and as the gates are raised and lowered, the pointer moves up and down the ruler to indicate the position of the gates. The low-flow gate does not have reference equipment. The Shand \& Jurs gage value is assumed correct.

The Sutron 8210 datalogger is powered by a 12-VDC battery, which is charged by an automatic sealed lead-acid battery charger connected to a $120-\mathrm{VAC}$ wall outlet. The position transmitters are powered by 24 VDC from a DC-DC converter that converts 12 VDC to 24 VDC.

The setup file (RRLT2.SET) for the datalogger is stored on the RAM card that is kept inside the Sutron equipment box. A hard copy of the setup file is also kept in the station folder.

The positions of Floodgates No. 1 and No. 2 are transmitted by satellite and posted on the USACE Web site (http://www.swf-wc.usace.army.mil) under Daily Reports/Gate Sensor Report. The USACE reports hourly data; however, the Sutron datalogger measures and records the gate position for the two gates every 15 minutes.

Floodgates No. 1 and No. 2 are FG1 and FG2, respectively, in the Sutron setup file.

\section{Operation and Maintenance}

Operation and maintenance information for the equipment at Ray Roberts Dam includes descriptions of different procedures required to maintain equipment such as routine inspections, recalibration of Floodgates No. 1 and No. 2, and annual inspections. The purpose of a site visit and the actions taken should be documented in the logbook kept near the datalogger. Include the date, time, actions, and personnel conducting the site visit in the logbook. This section lists some of the potential problems that might occur with the equipment in service and possible solutions to the problems. Refer to the Operations Manuals for the individual pieces of equipment when further detail is required. The information included here is basic operations and maintenance information.

For each visit to the site, personnel should carry all of the necessary tools required to service the equipment. The tools required to perform all of the tasks listed include the following:

- Screwdrivers, flat and Phillips head

- Crescent wrench, 10-in. 
- Stepladder, $10-\mathrm{ft}$

- Electrical tape

- Digital multimeter

- Pliers

- Ruler

- Laptop computer capable of connecting (with RS-232 port and 9-pin cable) to Sutron 8210

- Sutron 8210 Operations Manual

- Shand \& Jurs 92020 and 92021 Instruction Manuals

- Whessoe Varec 8200 Installation and Operations Manual

- Battery load tester

- Spare battery

- Flashlight

- Silicone sealant

\section{Procedures during a routine inspection}

- Check the enclosure to the Sutron 8210 datalogger for damage and moisture. If moisture is entering the enclosure, seal any openings with silicone.

- Scroll through the VIEW DATA/LIVE READINGS menu and check that the datalogger is making measurements.

- Check the antennas (data and GPS) and make sure connections are secure and waterproofed. Replace electrical tape around connections if old and brittle.

- Check the battery voltage under the LIVE READINGS menu on the Sutron 8210.

- If voltage is low (less than $11.5 \mathrm{~V}$ ), test the battery with a load tester and make sure the voltage remains above the recommended voltage specific to the load tester being used. Replace battery as needed.

- Remove drain plug on bottom of position sensor and allow water to drain out.

- Verify that the Shand \& Jurs position sensors and the Sutron 8210 datalogger measure the same values (within $0.01 \mathrm{ft}$ ) for the positions of Floodgates No. 1 and No. 2. Next, compare the values from the position sensors and the datalogger to the pointer reading. If the position sensors and datalogger values are within $0.01 \mathrm{ft}$ of each other and within $0.05 \mathrm{ft}$ of the pointer reading, no action is required. If the position sensors and the datalogger values differ by more than $0.01 \mathrm{ft}$ or by more than $0.05 \mathrm{ft}$ of the pointer reading, refer to the recalibration procedures.

- Before leaving the site, make sure the Sutron 8210 is reading ON \& TX under RECORDING.

\section{Procedures to recalibrate Floodgates No. 1 and No. 2}

- Completely lower the gate requiring calibration and set the Shand \& Jurs position sensor to measure 0.00. Make sure the pointer and the ruler also are reading 0.00. To set the position sensor to read 0.00 , open the counter access cover on top of the unit above the dial window. Hold the notched wheel, located to the right of the increments wheel, and turn the increments wheel until the counter measures the correct position, 0.00 . If the position sensor measures 0.00 when the gate is lowered completely, only the Sutron requires calibration. 
- Caution: Before executing this procedure, make sure the emergency bulkheads have been lowered. To calibrate the Sutron after setting the Shand \& Jurs unit to measure 0.00 , first record the current slope and offset for the gate being calibrated. Next, set the slope and the offset to 1.00 and 0.00 , respectively. With the gate still completely closed, scroll down to SYSTEM SETUP. Press the right arrow once and scroll down to CONFIG SENSORS. Press the right arrow once and scroll down to the gate that is being calibrated. With the correct gate selected, press the right arrow once and scroll down to VALUE. Enter the correct value, which would be 0.00 , then press the SET button. Next, open the gate as much as possible so that the instrument will be calibrated over the entire range of gate positions. With the gate open as much as possible, enter the value from the Shand $\&$ Jurs dial into the VALUE field and press the SET button. The datalogger will calculate the slope and the offset from the two known positions entered.

- Verify that the Shand \& Jurs position sensor and the Sutron 8210 datalogger are now measuring the same position with the gate open as much as possible. Also verify that the measurements are within $0.05 \mathrm{ft}$ of the pointer reading. After verification, close the gate completely and check that both measure 0.00 with the gate completely closed; if so, the calibration is complete; if not, perform the calibration again.

- Whenever a change is made to the setup file in the datalogger, download the new file to the RAM card kept at the site. To do this, insert the RAM card into the socket and turn on the 8210. Scroll down to the DUMP DATA menu. Press the right arrow once, then press the down arrow until WRITE CARD SETUP is displayed. Press the SET button and wait for the file to be transferred from the datalogger to the RAM card. To transfer the file from the RAM card to the datalogger, scroll down to the DUMP DATA menu. Press the right arrow once, then press the down arrow until READ CARD SETUP is displayed. Press the right arrow to access the setup file. Transfer the selected file to the datalogger by pressing the SET button.

- Record changes to the slope or the offset in the logbook.

\section{Procedures during an annual inspection}

- During an inspection the emergency bulkheads are lowered, and the floodgates are raised all the way up and cleaned and inspected. As the gates are lowered after being serviced, check that the position sensors and datalogger measure the same values. If not, follow the instructions to recalibrate the instruments.

- After the inspection, follow all of the procedures during a routine inspection. 
Table 11. Ray Roberts Lake equipment inventory

[See table of contents for abbreviated units; --, not available or not applicable]

\begin{tabular}{|c|c|c|c|c|}
\hline Item no. & Item description & Manufacturer & Model no. & Remarks \\
\hline 1. & $\begin{array}{l}\text { Floodgate No. } 1 \text { position } \\
\text { sensor }\end{array}$ & Shand \& Jurs & 92020 & $\begin{array}{l}\text { Gate is FG1 in Sutron setup and equipment is labeled } \\
\text { with numeral } 1\end{array}$ \\
\hline 2. & $\begin{array}{l}\text { Floodgate No. } 1 \text { position } \\
\text { transmitter }\end{array}$ & Whessoe Varec & 82000200 & $\begin{array}{l}\text { Analog transmitter with current output of } 4 \text { to } 20 \mathrm{~mA} \text { and } \\
\text { input of } 15 \text { to } 48 \text { VDC }\end{array}$ \\
\hline 3. & $\begin{array}{l}\text { Wire for position transmitter } \\
\text { No. } 1\end{array}$ & -- & -- & $55 \mathrm{ft}$ of $14 \mathrm{AWG} / 5$ wires but only 2 wires are used \\
\hline 4. & $\begin{array}{l}\text { Floodgate No. } 2 \text { position } \\
\text { sensor }\end{array}$ & Shand \& Jurs & 92020 & $\begin{array}{l}\text { Gate is FG2 in Sutron setup and equipment is labeled } \\
\text { with numeral } 2\end{array}$ \\
\hline 5. & $\begin{array}{l}\text { Floodgate No. } 2 \text { position } \\
\text { transmitter }\end{array}$ & Whessoe Varec & 82000200 & $\begin{array}{l}\text { Analog transmitter with current output of } 4 \text { to } 20 \mathrm{~mA} \text { and } \\
\text { input of } 15 \text { to } 48 \text { VDC }\end{array}$ \\
\hline 6. & $\begin{array}{l}\text { Wire for position transmitter } \\
\text { No. } 2\end{array}$ & -- & -- & $55 \mathrm{ft}$ of $14 \mathrm{AWG} / 5$ wires but only 2 wires are used \\
\hline 7. & Stage shaft encoder & Handar & $436 \mathrm{~A}$ & -- \\
\hline 8. & Rain gage & $\begin{array}{l}\text { Texas Electronics, } \\
\text { Inc. }\end{array}$ & TR-525I & -- \\
\hline 9. & Datalogger & Sutron & 8210 & -- \\
\hline 10. & Battery & Power Sonic & PS-12550U & 12-V, 55.0-A-h battery for Sutron 8210 \\
\hline 11. & Battery charger & Power Sonic & PSC-12800A & $12-\mathrm{V}, 800-\mathrm{mA}$ \\
\hline 12. & DC-DC converter & Power-One & DFC10U24D12 & $\begin{array}{l}\text { Converts } 12 \text { VDC to } 24 \text { VDC to power position } \\
\text { transmitters }\end{array}$ \\
\hline 13. & Antenna & -- & YAGI & Mounted on downstream side of intake structure \\
\hline 14. & Antenna cable & Alpha Wire-J & RG 8/U & 30-ft cable from Sutron 8210 to antenna \\
\hline 15. & Data transmitter & Sutron & Satlink & -- \\
\hline 16. & GPS antenna & Trimble & Bullet III & -- \\
\hline 17. & GPS antenna cable & Belden-T & $1189 \mathrm{~A}$ & 70-ft cable from Sutron 8210 to antenna \\
\hline
\end{tabular}




\section{Job Hazard Analysis}

Required protective clothing, safety equipment, and supplies: Personal flotation device (PFD), reflective vest, gloves, steel-toed shoes, waders, cell phone, first aid kit, fire extinguisher, rotating or strobe type emergency lights, drinking water.

\begin{tabular}{|c|c|c|}
\hline $\begin{array}{l}\text { Sequence of basic } \\
\text { job steps }\end{array}$ & $\begin{array}{l}\text { Potential } \\
\text { accident or hazard }\end{array}$ & Recommended safe job procedures \\
\hline $\begin{array}{l}\text { Upon job } \\
\text { assignment }\end{array}$ & $\begin{array}{l}\text { Water-related accident or } \\
\text { injury }\end{array}$ & $\begin{array}{l}\text { Employees working in and around water must receive } \\
\text { training specified in WRD Memo 2000.10, "Policy for } \\
\text { safety training associated with over-water activities." }\end{array}$ \\
\hline $\begin{array}{l}\text { Loading and } \\
\text { unloading } \\
\text { equipment }\end{array}$ & $\begin{array}{l}\text { Pinched fingers, mashed } \\
\text { toes, or strained back }\end{array}$ & $\begin{array}{l}\text { Be aware of hand placement. Wear protective gloves and } \\
\text { steel-toed shoes. Use proper lifting techniques. Lift with } \\
\text { legs. Use extra caution lifting heavy sounding weights. }\end{array}$ \\
\hline $\begin{array}{l}\text { Driving to and } \\
\text { returning from work } \\
\text { site }\end{array}$ & $\begin{array}{l}\text { Traffic accidents, vehicle } \\
\text { flooding, or drowning }\end{array}$ & $\begin{array}{l}\text { Drivers of USGS vehicles must have Drivers Safety } \\
\text { Training (SM 445-2-H, chap. 16). Be alert to traffic in } \\
\text { area, obey all traffic laws, and reduce speed when weather } \\
\text { conditions are bad. Do not drive across flooded highways } \\
\text { unless water depth and bridge conditions are known to be } \\
\text { safe. }\end{array}$ \\
\hline Parking vehicle & $\begin{array}{l}\text { Personal and vehicle } \\
\text { safety when exiting } \\
\text { vehicle in traffic; bank } \\
\text { collapse or bridge failure }\end{array}$ & $\begin{array}{l}\text { Use rotating or strobe emergency lights, follow site } \\
\text { traffic-control plan, wear DOT Type III reflective vest } \\
\text { when working in or near roadway. Park away from stream } \\
\text { at a safe distance from banks. }\end{array}$ \\
\hline $\begin{array}{l}\text { Set up traffic- } \\
\text { control equipment }\end{array}$ & $\begin{array}{l}\text { Personal and public } \\
\text { safety }\end{array}$ & $\begin{array}{l}\text { Employees working in or near roadways must have Work } \\
\text { Zone Traffic-Control Safety Training. Remain alert to } \\
\text { traffic conditions. }\end{array}$ \\
\hline $\begin{array}{l}\text { Working at field } \\
\text { site }\end{array}$ & Drowning & $\begin{array}{l}\text { Employees are required to wear a PFD when working in, } \\
\text { on, or over any body of water. There are no exemptions } \\
\text { for employees in the Texas WSC. PFDs will be } \\
\text { international orange in color and equipped with reflective } \\
\text { tape in accordance with } 46 \text { CFR } 25.25-15 \text {. Self-inflating } \\
\text { PFDs are not to be worn by employees who have not had } \\
\text { In-Water Safety Training. }\end{array}$ \\
\hline $\begin{array}{l}\text { Working at field } \\
\text { site }\end{array}$ & Trips, slips, and falls & $\begin{array}{l}\text { Follow path clear of obstructions and with minimal slope; } \\
\text { avoid slippery surfaces. Walk cautiously on steep slopes } \\
\text { or paths with loose material. Use appropriate footwear for } \\
\text { the terrain and conditions. Follow the safest, not the } \\
\text { fastest path! }\end{array}$ \\
\hline $\begin{array}{l}\text { Working at field } \\
\text { site }\end{array}$ & $\begin{array}{l}\text { Dehydration, heat } \\
\text { exhaustion, heat stroke, } \\
\text { or sunburn }\end{array}$ & $\begin{array}{l}\text { Drink plenty of water or electrolyte drink. Wear } \\
\text { appropriate clothing. Take occasional breaks and watch } \\
\text { for symptoms of heat exhaustion. Use sun block. }\end{array}$ \\
\hline $\begin{array}{l}\text { Working at field } \\
\text { site }\end{array}$ & Hypothermia or frostbite & $\begin{array}{l}\text { Wear foul-weather gear during winter months. Keep } \\
\text { clothing dry. }\end{array}$ \\
\hline $\begin{array}{l}\text { Working at field } \\
\text { site }\end{array}$ & Snake bites & $\begin{array}{l}\text { Wear appropriate foot and leg protection. Watch path } \\
\text { ahead. Keep area around gage clear of brush. If bitten, } \\
\text { seek immediate medical help. }\end{array}$ \\
\hline
\end{tabular}




\begin{tabular}{|l|l|l|}
\hline $\begin{array}{l}\text { Working at field } \\
\text { site }\end{array}$ & Poisonous plants & $\begin{array}{l}\text { Know how to identify poisonous plants. Wear protective } \\
\text { clothing. Wash and flush exposed areas immediately with } \\
\text { cold water. Wash with degreasing type soap and flush } \\
\text { from skin. Seek medical attention for severe reactions. }\end{array}$ \\
\hline Entering gage house & $\begin{array}{l}\text { Infectious disease or } \\
\text { airborne pollutants; risk } \\
\text { of hantavirus exposure. }\end{array}$ & $\begin{array}{l}\text { Watch for bats or rodent nests and droppings. If nest or } \\
\text { droppings are present, do not disturb dust. Gage should be } \\
\text { periodically cleaned to minimize risk of exposure. See } \\
\text { WRD memo dated 10/28/97, "Preventing hantavirus } \\
\text { disease," and OP memo dated 01/94, "Instructions for } \\
\text { preventing hantavirus disease." }\end{array}$ \\
\hline Entering gage house & Insect or snake bites & $\begin{array}{l}\text { Inspect in and around shelter for harmful insects. Use } \\
\text { wasp or insect spray. Inspect in and around shelter for } \\
\text { snakes prior to entry. }\end{array}$ \\
\hline
\end{tabular}

\section{Site-Specific Job Hazards}

The items listed are safety issues specific to this site that deserve special emphasis.

- Use caution descending the spiral staircase to go from the upper deck of the intake structure to the lower level where the gate sensing equipment for the main floodgates are located.

- The light switch for the lower level is on the east wall of the intake structure (opposite from Sutron 8210 datalogger) and is labeled "oper. lights." The lights need a few minutes to warm up before functioning. 
Figure 57. Ray Roberts Lake Sutron 8210 wiring panel.

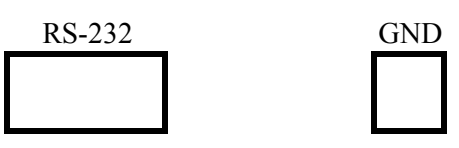

\begin{tabular}{|c|c|c|c|c|c|c|c|c|c|c|c|c|c|c|}
\hline 1 & 2 & 3 & 4 & 5 & 6 & 7 & 8 & 9 & 10 & 11 & 12 & 13 & 14 & $\mid 15$ \\
\hline & & & & & & & & & & & $T$ & & & $E$ \\
\hline $\mathrm{T}$ & R & $\mathrm{G}$ & 1 & $\mathrm{G}$ & 1 & 2 & $\mathrm{G}$ & 1 & 2 & $\mathrm{AG}$ & + & +5 & $\mathrm{AG}$ & + \\
\hline & & & & & ENC & & & $\mathrm{ENC2}$ & & & & REF & $\overline{\mathrm{A} 2}$ & \\
\hline
\end{tabular}

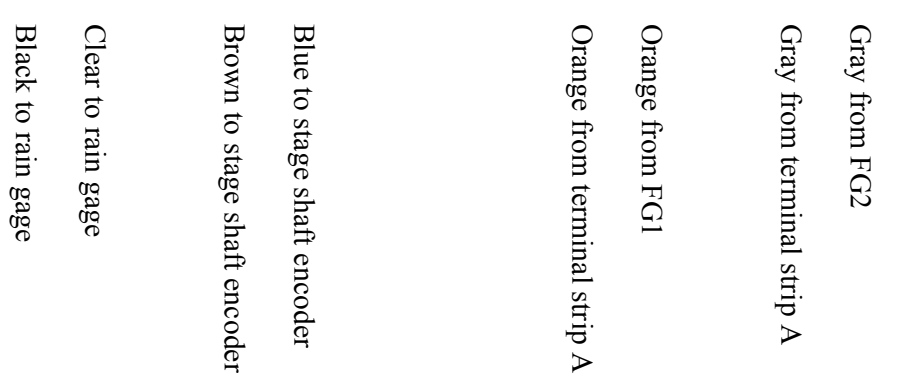

Note: FG1, Floodgate No. 1.

FG2, Floodgate No. 2.

+ denotes a resistor between the two ports of the Sutron

\begin{tabular}{|c|c|c|c|c|c|c|c|c|c|c|c|c|c|c|}
\hline \multicolumn{2}{|c|}{ Ext Batt } & \multicolumn{1}{c|}{ RS485 } & \multicolumn{3}{c|}{ SDI-12 } & \multicolumn{5}{c|}{ SDI-12 } & \multicolumn{5}{c|}{ Digital output } \\
\hline $\mathrm{G}$ & + & $\mathrm{A}$ & $\mathrm{B}$ & $\mathrm{G}$ & + & $\mathrm{D}$ & $\mathrm{G}$ & + & $\mathrm{D}$ & 1 & 2 & 3 & 4 & 5 \\
\hline & & & & & & & & & & & & & & \\
\hline 1 & 2 & 3 & 4 & 5 & 6 & 7 & 8 & 9 & 10 & 11 & 12 & 13 & 14 & 15 \\
\hline
\end{tabular}
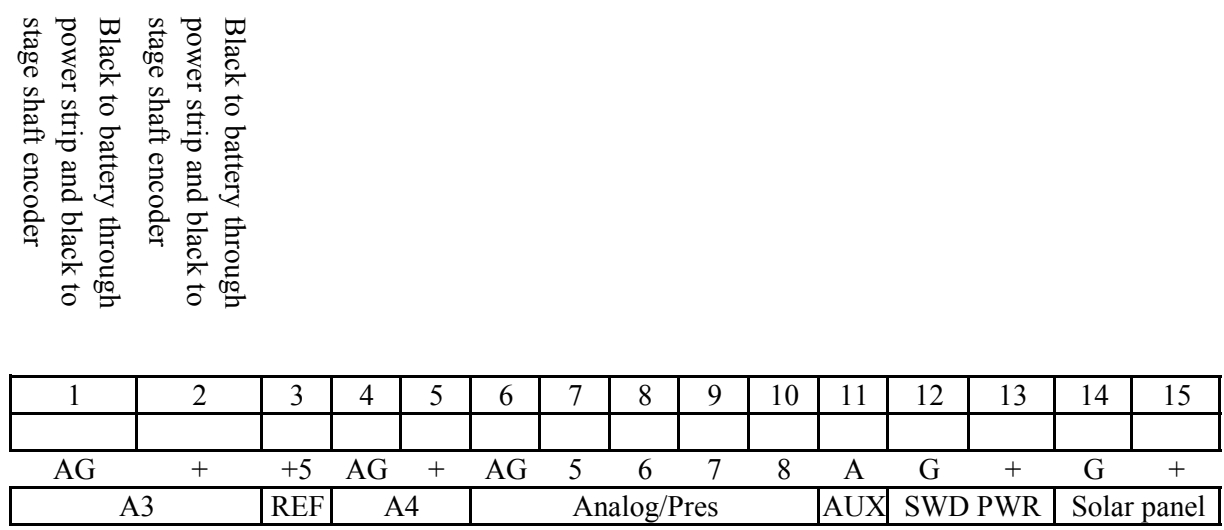

\begin{tabular}{|c|c|cc|cc|c|}
\hline REF & A4 & Analog/Pres & & AUX & SWD PWR & Solar panel \\
\hline
\end{tabular} 
Figure 58. Ray Roberts Lake equipment wiring diagram.
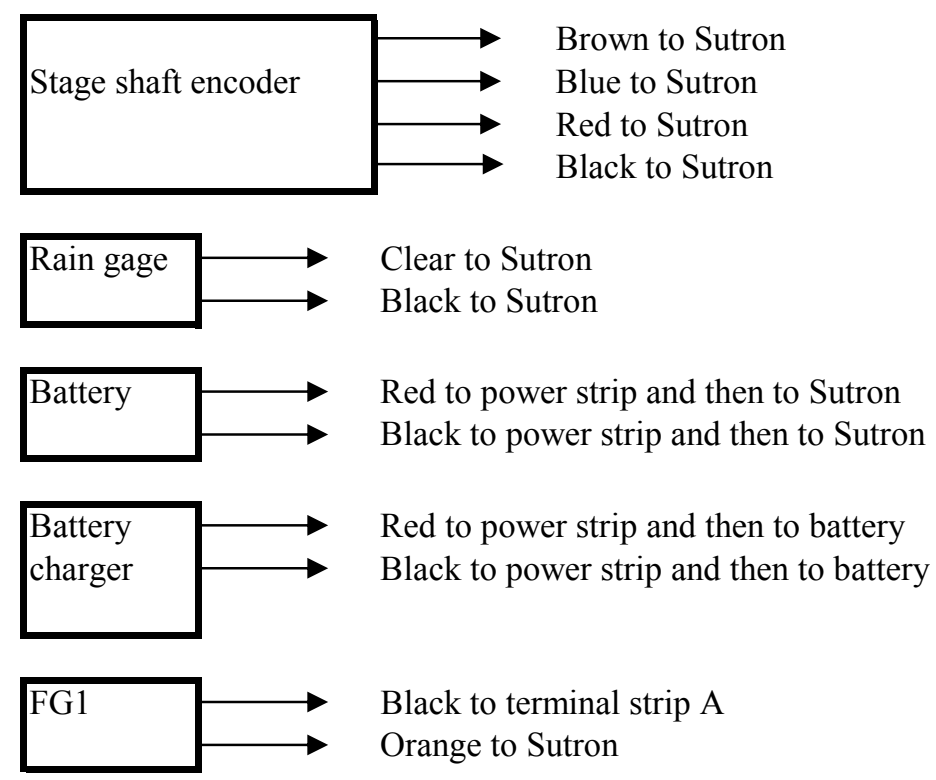

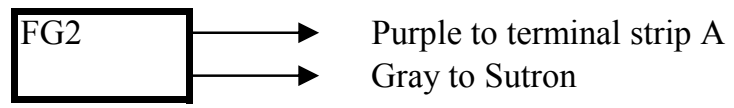

\section{Terminal strip A}

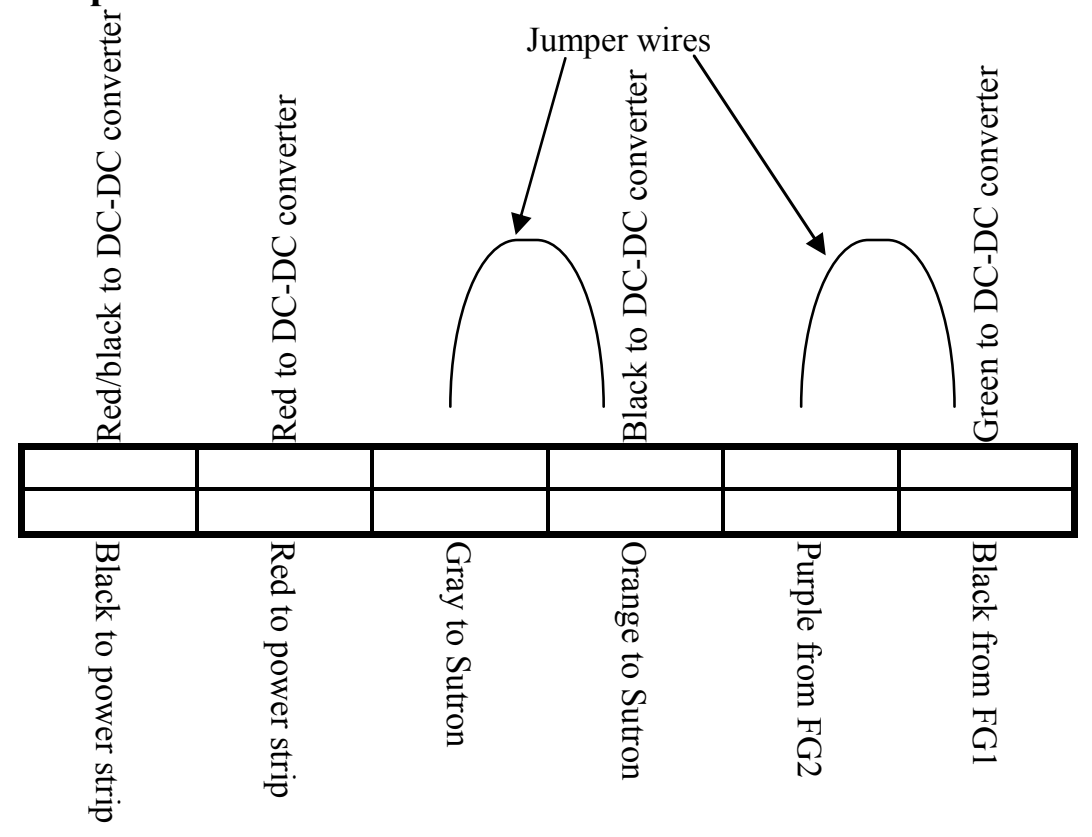

Note: $\quad$ FG1, Floodgate No. 1.

FG2, Floodgate No. 2. 


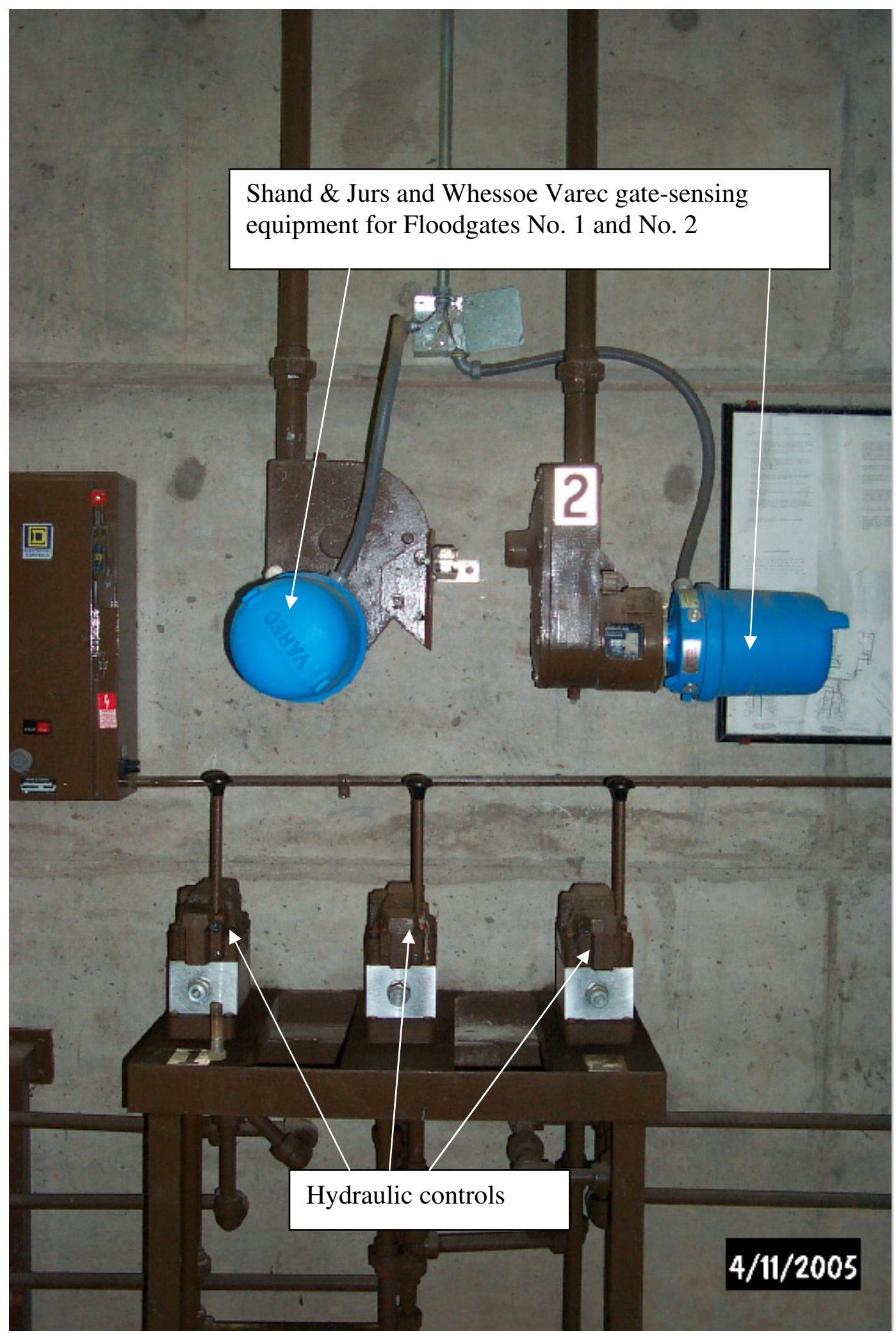

Figure 59. Gate-sensing equipment at Ray Roberts Lake. 


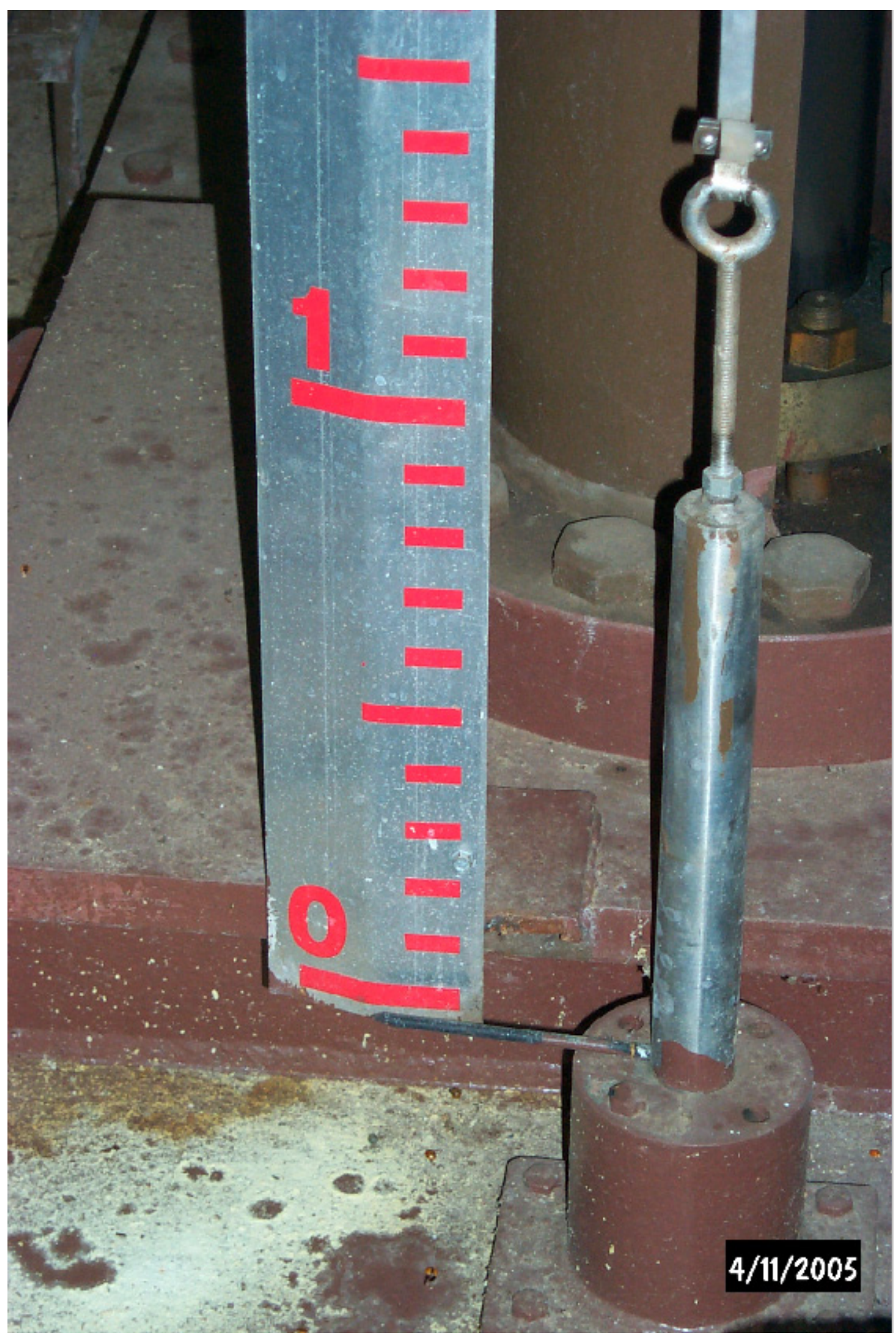

Figure 60. Ruler and pointer reference for Floodgate No. 2 at Ray Roberts Lake. 


\section{Ray Roberts Lake Sutron 8210 Setup File (RRLT2.SET)}

; 8210/8200 ASCII setup file, can be converted back to a .SET file with WSETMGR.EXE

;

; MAIN SETUP

;

Setup_Version $=$ V6X

Unit_ID=RRLT2

Measurement_Interval=00:15:00

Sampling_Interval=00:00:00

Measurement_Time $=00: 00: 00$

Sampling_Time $=00: 00: 00$

Switched_Power_Time $=00: 00: 00$

Samples_to_Average $=10$

Measurements_per_Log $=1$

Switched_Power_Mode=OFF

Recording $=\mathrm{ON}$

Basic_Run_Interval=00:00:00

Basic_Run_Time $=00: 00: 00$

Password=

Number_Resets $=4$

Log_Size $=124928$

Rom_Checksum=57134

; EEROM SETUP

Serial_Port_Mode=USER

User_Baud_Rate $=9600$

Radio_Baud_Rate $=1200$

Com_Baud_Rate $=9600$

Transfer_Baud_Rate $=9600$

SDI_Baud_Rate $=1200$

Enter_Key_Reqd=OFF

Log_Dump_Mode=ALL-BIN

User_Time_Limit $=600$

Power_Delay $=1$

Analog_Delay $=5$

Pressure_Delay $=5$

Auto_Startup_Keys=SS

Time_Format=NORMAL

Date_Format=MDY

Term_Xmit_Delay $=0$

Basic_Size $=1$

Amp_Gain=1.0

;

; PROTOCOL SETUP

Master_Name=

Carrier_Delay $=7$

Com_Port_Mode=

Reply_Delay $=0$

Ack_Delay $=100$ 


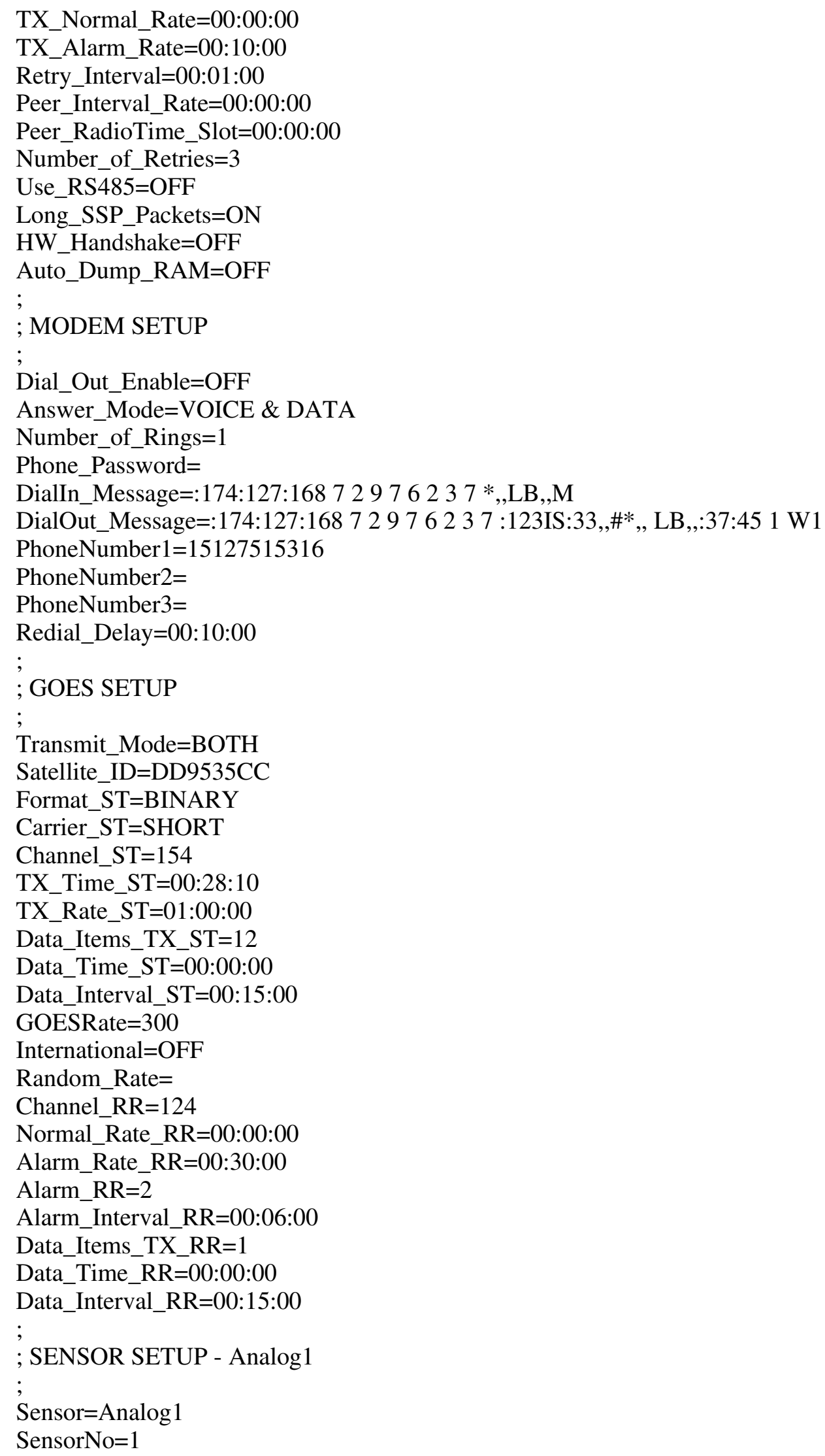




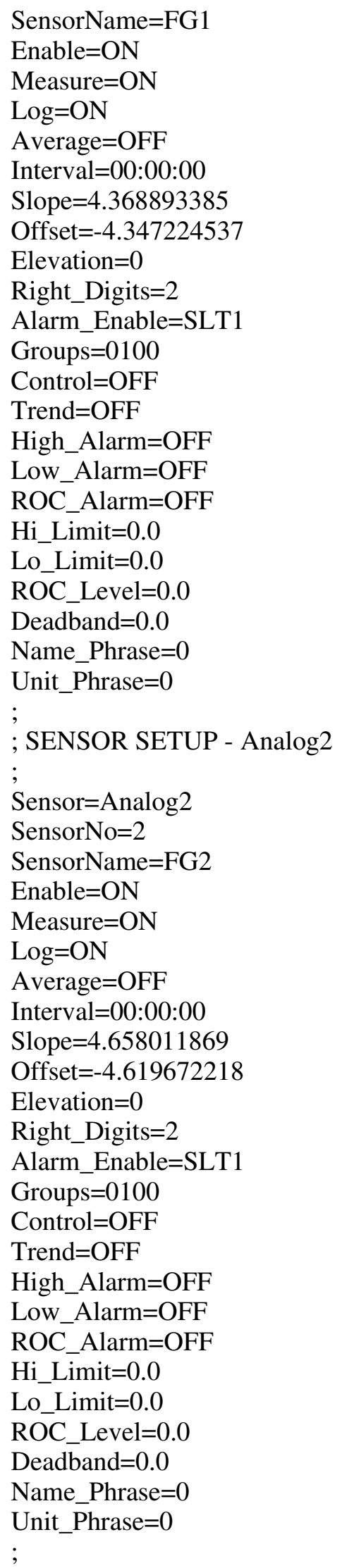




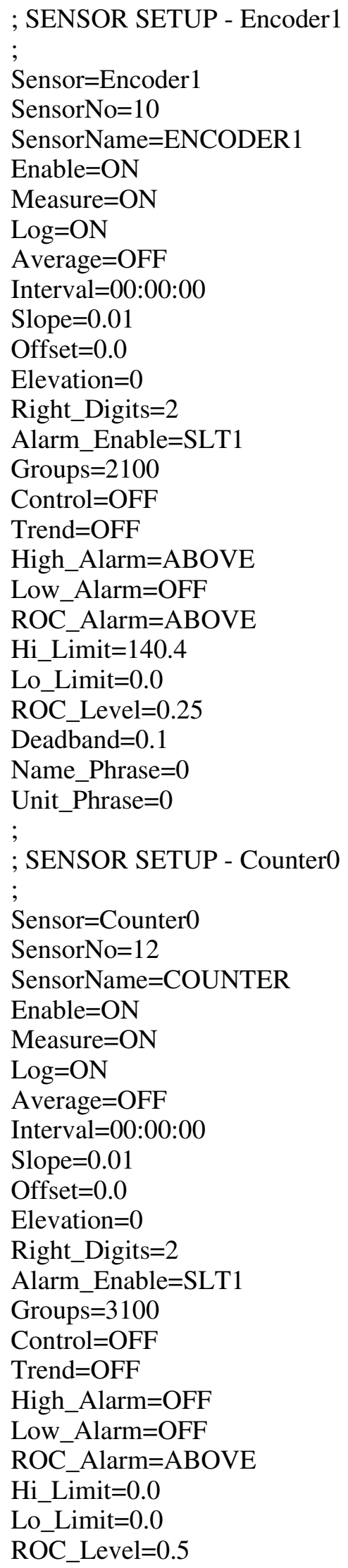


Deadband $=0.01$

Name_Phrase $=0$

Unit_Phrase $=0$

;

; SENSOR SETUP - Battery

;

Sensor=Battery

SensorNo=34

SensorName $=$ BATTERY

Enable $=\mathrm{ON}$

Measure $=\mathrm{ON}$

$\mathrm{Log}=\mathrm{ON}$

Average $=\mathrm{OFF}$

Interval=04:00:00

Slope $=1.0$

Offset $=0.0$

Elevation $=0$

Right_Digits $=2$

Alarm_Enable $=\mathrm{OFF}$

Groups $=0000$

Control $=$

Trend $=\mathrm{OFF}$

High_Alarm $=\mathrm{OFF}$

Low_Alarm $=\mathrm{OFF}$

ROC_Alarm $=\mathrm{OFF}$

Hi_Limit $=0.0$

Lo_Limit $=0.0$

ROC_Level $=0.0$

Deadband $=0.0$

Name_Phrase $=0$

Unit_Phrase $=0$ 


\section{Somerville Lake Near Somerville, Tex.}

\section{Location}

Lat 30¹9'20", long 96³1'32", Burleson County, in intake structure of Somerville Dam on Yegua Creek, at southwest edge of the city limits of Somerville, and $20.0 \mathrm{mi}$ upstream from mouth.

\section{Road Log}

From USGS Texas WSC-Fort Worth, travel I-35 south to Temple. Exit onto SH 36 and travel south. Continue on SH 36 for about $70 \mathrm{mi}$ to Somerville. Turn right off SH 36 onto Thornberry Dr. and travel $1.5 \mathrm{mi}$ to USACE office. The intake structure is past the USACE office on Thornberry Dr.

\section{Access}

Before visiting the site, call the Somerville Dam USACE office at 979-596-1622 to let them know you will be servicing the site. The lock on the fence to the equipment requires a $2640 \mathrm{key}$. The intake structure is open; therefore, no alarm protects the equipment.

\section{Equipment Description}

Refer to table 12, "Somerville Lake equipment inventory," for a complete list of equipment and to figures 61-63 for equipment wiring diagrams and photographs of equipment. Two main floodgates and two emergency gates are raised and lowered by EIM Controls electric valve operators. The floodgates and the emergency gates are labeled with numerals 1 through 4 . Floodgate No. 1 is labeled numeral 1 and is on the left side of the intake structure (facing upstream); Floodgate No. 2 is labeled numeral 2 and is on the right. Similarly, Emergency Gates No. 1 and No. 2 are located on the left and right side (facing upstream), respectively, of the intake structure. Emergency Gate No. 1 is labeled numeral 3 and Emergency Gate No. 2 is labeled numeral 4. The upper deck of the intake structure at Somerville Lake is open but has a roof to protect the equipment from the weather. However, the roof was not in place when the picture was taken (fig. 63).

The floodgates have shaft encoders that send a signal to the Sutron datalogger to indicate the position of the gates. A wire is attached to a threaded rod that is attached to the top of the gate. The wire travels over the pulley of the shaft encoder; as the gates are raised and lowered, the pulley rotates. The rotation of the shaft encoder pulley indicates the amount of linear displacement of the gate.

Floodgates and emergency gates have dials to indicate gate position; however, the dials should not be used as a reference for the two floodgates. According to the USACE operators, the dials are not accurate and should not be used to calibrate the shaft encoders, and the floodgates move about $1 \mathrm{ft}$ for every 2 minutes the motors are run to raise the gates. 
The Sutron 8210 datalogger is powered by a 12-VDC battery, which is charged by an automatic sealed lead-acid battery charger connected to a $120-\mathrm{VAC}$ wall outlet. The shaft encoders are powered by the Sutron 8210 datalogger.

The setup file (LAKSOMER.SET) is stored on the RAM card that is kept inside the Sutron equipment box. A hard copy of the setup file and the basic program file is also kept in the station folder.

The positions of Floodgates No. 1 and No. 2 are transmitted by satellite and posted on the USACE Web site (http://www.swf-wc.usace.army.mil) under Daily Reports/Gate Sensor Report. The USACE reports hourly data; however, the Sutron datalogger measures and records the gate position for the two gates every 15 minutes.

Floodgates No. 1 and No. 2 are FG1 and FG2, respectively, in the Sutron datalogger setup file.

\section{Operation and Maintenance}

Operation and maintenance information for the equipment at Somerville Dam includes descriptions of different procedures required to maintain equipment such as routine inspections, recalibration of Floodgates No. 1 and No. 2, and annual inspections. The purpose of a site visit and the actions taken should be documented in the logbook kept near the datalogger. Include the date, time, actions, and personnel conducting the site visit in the logbook. This section lists some of the potential problems that might occur with the equipment in service and possible solutions to the problems. Refer to the Operations Manuals for the individual pieces of equipment when further detail is required. The information included here is basic operations and maintenance information.

For each visit to the site, personnel should carry all of the necessary tools required to service the equipment. The tools required to perform all of the tasks listed include the following:

- Screwdrivers, flat and Phillips head

- Allen wrenches, 5/32- and 7/64-in.

- Crescent wrench, 10-in.

- Stepladder, 10-ft

- Electrical tape

- Digital multimeter

- Pliers

- Ruler

- Laptop computer capable of connecting (with RS-232 port and 9-pin cable) to Sutron 8210

- Sutron 8210 Operations Manual

- Battery load tester

- Spare battery

- Flashlight

- Silicone sealant

\section{Procedures during a routine inspection}

- Check the enclosure to the Sutron 8210 datalogger for damage and moisture. If moisture is entering the enclosure, seal any openings with silicone. 
- Scroll through the VIEW DATA/LIVE READINGS menu and check that the datalogger is making measurements.

- Check the antennas (data and GPS) and make sure connections are secure and waterproofed. Replace electrical tape around connections if old and brittle.

- Check the battery voltage under the LIVE READINGS menu on the Sutron 8210.

- If voltage is low (less than $11.5 \mathrm{~V}$ ), test the battery with a load tester and make sure the voltage remains above the recommended voltage specific to the load tester being used. Replace battery as needed.

- If possible, have the gates lowered completely and check that the Sutron 8210 measures 0.00 for the position of the floodgates; recalibrate if different (within $0.01 \mathrm{ft}$ ).

- Before leaving the site, make sure the Sutron 8210 is reading ON \& TX under RECORDING.

\section{Procedures to recalibrate Floodgates No. 1 and No. 2}

- First make sure that the slope of the shaft encoders is set to 0.01.With the gates closed, set the instruments to read 0.00 by adjusting the offset of the shaft encoders.

- To change the offset or the slope, turn on the Sutron 8210 and press the down arrow to SYSTEM SETUP. Press the right arrow once and the down arrow twice to CONFIG SENSORS. Then press the right arrow once and the down arrow to select either FG1 or FG2. With the correct shaft encoder selected, press the right arrow once and then the down arrow to slope and offset. Press the SET button once when either slope or offset are highlighted. Change the value using the arrow buttons. Right and left arrow buttons move from one digit to the next. Up and down arrow buttons increase or decrease the value, respectively. When finished, press the SET button to save the new value. Check LIVE READINGS or the digital display to see the new measured value.

- Whenever a change is made to the setup file in the datalogger, download the new file to the RAM card kept at the site. To do this, insert the RAM card into the socket and turn on the 8210. Scroll down to the DUMP DATA menu. Press the right arrow once and then press the down arrow until WRITE CARD SETUP is displayed. Press the SET button and wait for the file to be transferred from the datalogger to the RAM card. To transfer the file from the RAM card to the datalogger, scroll down to the DUMP DATA menu. Press the right arrow once, then press the down arrow until READ CARD SETUP is displayed. Press the right arrow to access the setup file. Transfer the selected file to the datalogger by pressing the SET button.

- Record changes to the slope or the offset in the logbook.

\section{Procedures during an annual inspection}

- During an inspection the emergency gates are lowered, and the floodgates are raised all the way up and cleaned and inspected. After the gates are lowered, check that the datalogger measures 0.00 . If not, follow the instructions on how to recalibrate the instruments.

- After the inspection, follow all of the procedures for a routine inspection. 
Table 12. Somerville Lake equipment inventory.

[See table of contents for abbreviated units; --, not available or not applicable]

\begin{tabular}{|c|c|c|c|c|}
\hline Item no. & Item description & Manufacturer & Model no. & Remarks \\
\hline 1. & $\begin{array}{l}\text { Floodgate No. } 1 \text { position } \\
\text { transmitter }\end{array}$ & Handar & $436 \mathrm{~A}$ & $\begin{array}{l}\text { Gate is FG1 in Sutron setup and equipment is labeled } \\
\text { FG1 }\end{array}$ \\
\hline 2. & $\begin{array}{l}\text { Wire for position transmitter } \\
\text { No. } 1\end{array}$ & -- & -- & $23 \mathrm{ft}$ of $22 \mathrm{AWG} / 4$ wires \\
\hline 3. & $\begin{array}{l}\text { Floodgate No. } 2 \text { position } \\
\text { transmitter }\end{array}$ & Handar & 436A & $\begin{array}{l}\text { Gate is FG2 in Sutron setup and equipment is labeled } \\
\text { FG2 }\end{array}$ \\
\hline 4. & $\begin{array}{l}\text { Wire for position transmitter } \\
\text { No. } 2\end{array}$ & -- & -- & $23 \mathrm{ft}$ of $22 \mathrm{AWG} / 4$ wires \\
\hline 5. & Stage shaft encoder & Sutron & SE8500 & ELEV in Sutron setup and has SDI12 address 0 \\
\hline 6. & Rain gage & Texas Electronics, Inc. & TR-525I & $-\overline{-}$ \\
\hline 7. & Datalogger & Sutron & 8210 & -- \\
\hline 8. & Battery & Power Sonic & PS-12550U & 12-V, 55.0-A-h battery for Sutron 8210 \\
\hline 9. & Battery charger & Power Sonic & PSC-12500A & $12-\mathrm{V}, 500-\mathrm{mA}$ \\
\hline 10. & Antenna & Sutron & $5000-0080$ & -- \\
\hline 11. & Antenna cable & -- & RG 8/U & 30 -ft cable from Sutron 8210 to antenna \\
\hline 12. & Data transmitter & Sutron & Satlink & -- \\
\hline 13. & GPS antenna & Trimble & Miniature 5V & Magnetic mount on side of shelter \\
\hline 14. & GPS antenna cable & Trimble & -- & Cable comes with antenna \\
\hline
\end{tabular}




\section{Job Hazard Analysis}

Required protective clothing, safety equipment, and supplies: Personal flotation device (PFD), reflective vest, gloves, steel-toed shoes, waders, cell phone, first aid kit, fire extinguisher, rotating or strobe type emergency lights, drinking water.

\begin{tabular}{|c|c|c|}
\hline $\begin{array}{l}\text { Sequence of basic } \\
\text { job steps }\end{array}$ & $\begin{array}{l}\text { Potential } \\
\text { accident or hazard }\end{array}$ & Recommended safe job procedures \\
\hline $\begin{array}{l}\text { Upon job } \\
\text { assignment }\end{array}$ & $\begin{array}{l}\text { Water-related accident or } \\
\text { injury }\end{array}$ & $\begin{array}{l}\text { Employees working in and around water must receive } \\
\text { training specified in WRD Memo 2000.10, "Policy for } \\
\text { safety training associated with over-water activities." }\end{array}$ \\
\hline $\begin{array}{l}\text { Loading and } \\
\text { unloading } \\
\text { equipment }\end{array}$ & $\begin{array}{l}\text { Pinched fingers, mashed } \\
\text { toes, or strained back }\end{array}$ & $\begin{array}{l}\text { Be aware of hand placement. Wear protective gloves and } \\
\text { steel-toed shoes. Use proper lifting techniques. Lift with } \\
\text { legs. Use extra caution lifting heavy sounding weights. }\end{array}$ \\
\hline $\begin{array}{l}\text { Driving to and } \\
\text { returning from work } \\
\text { site }\end{array}$ & $\begin{array}{l}\text { Traffic accidents, vehicle } \\
\text { flooding, or drowning }\end{array}$ & $\begin{array}{l}\text { Drivers of USGS vehicles must have Drivers Safety } \\
\text { Training (SM 445-2-H, chap. 16). Be alert to traffic in } \\
\text { area, obey all traffic laws, and reduce speed when weather } \\
\text { conditions are bad. Do not drive across flooded highways } \\
\text { unless water depth and bridge conditions are known to be } \\
\text { safe. }\end{array}$ \\
\hline Parking vehicle & $\begin{array}{l}\text { Personal and vehicle } \\
\text { safety when exiting } \\
\text { vehicle in traffic; bank } \\
\text { collapse or bridge failure }\end{array}$ & $\begin{array}{l}\text { Use rotating or strobe emergency lights, follow site } \\
\text { traffic-control plan, wear DOT Type III reflective vest } \\
\text { when working in or near roadway. Park away from stream } \\
\text { at a safe distance from banks. }\end{array}$ \\
\hline $\begin{array}{l}\text { Set up traffic- } \\
\text { control equipment }\end{array}$ & $\begin{array}{l}\text { Personal and public } \\
\text { safety }\end{array}$ & $\begin{array}{l}\text { Employees working in or near roadways must have Work } \\
\text { Zone Traffic-Control Safety Training. Remain alert to } \\
\text { traffic conditions. }\end{array}$ \\
\hline $\begin{array}{l}\text { Working at field } \\
\text { site }\end{array}$ & Drowning & $\begin{array}{l}\text { Employees are required to wear a PFD when working in, } \\
\text { on, or over any body of water. There are no exemptions } \\
\text { for employees in the Texas WSC. PFDs will be } \\
\text { international orange in color and equipped with reflective } \\
\text { tape in accordance with } 46 \text { CFR } 25.25-15 \text {. Self-inflating } \\
\text { PFDs are not to be worn by employees who have not had } \\
\text { In-Water Safety Training. }\end{array}$ \\
\hline $\begin{array}{l}\text { Working at field } \\
\text { site }\end{array}$ & Trips, slips, and falls & $\begin{array}{l}\text { Follow path clear of obstructions and with minimal slope; } \\
\text { avoid slippery surfaces. Walk cautiously on steep slopes } \\
\text { or paths with loose material. Use appropriate footwear for } \\
\text { the terrain and conditions. Follow the safest, not the } \\
\text { fastest path! }\end{array}$ \\
\hline $\begin{array}{l}\text { Working at field } \\
\text { site }\end{array}$ & $\begin{array}{l}\text { Dehydration, heat } \\
\text { exhaustion, heat stroke, } \\
\text { or sunburn }\end{array}$ & $\begin{array}{l}\text { Drink plenty of water or electrolyte drink. Wear } \\
\text { appropriate clothing. Take occasional breaks and watch } \\
\text { for symptoms of heat exhaustion. Use sun block. }\end{array}$ \\
\hline $\begin{array}{l}\text { Working at field } \\
\text { site }\end{array}$ & Hypothermia or frostbite & $\begin{array}{l}\text { Wear foul-weather gear during winter months. Keep } \\
\text { clothing dry. }\end{array}$ \\
\hline $\begin{array}{l}\text { Working at field } \\
\text { site }\end{array}$ & Snake bites & $\begin{array}{l}\text { Wear appropriate foot and leg protection. Watch path } \\
\text { ahead. Keep area around gage clear of brush. If bitten, } \\
\text { seek immediate medical help. }\end{array}$ \\
\hline
\end{tabular}




\begin{tabular}{|l|l|l|}
\hline $\begin{array}{l}\text { Working at field } \\
\text { site }\end{array}$ & Poisonous plants & $\begin{array}{l}\text { Know how to identify poisonous plants. Wear protective } \\
\text { clothing. Wash and flush exposed areas immediately with } \\
\text { cold water. Wash with degreasing type soap and flush } \\
\text { from skin. Seek medical attention for severe reactions. }\end{array}$ \\
\hline Entering gage house & $\begin{array}{l}\text { Infectious disease or } \\
\text { airborne pollutants; risk } \\
\text { of hantavirus exposure }\end{array}$ & $\begin{array}{l}\text { Watch for bats or rodent nests and droppings. If nest or } \\
\text { droppings are present, do not disturb dust. Gage should be } \\
\text { periodically cleaned to minimize risk of exposure. See } \\
\text { WRD memo dated 10/28/97, "Preventing hantavirus } \\
\text { disease," and OP memo dated 01/94, "Instructions for } \\
\text { preventing hantavirus disease." }\end{array}$ \\
\hline Entering gage house & Insect or snake bites & $\begin{array}{l}\text { Inspect in and around shelter for harmful insects. Use } \\
\text { wasp or insect spray. Inspect in and around shelter for } \\
\text { snakes prior to entry. }\end{array}$ \\
\hline
\end{tabular}

\section{Site-Specific Job Hazards}

The items listed are safety issues specific to this site that deserve special emphasis.

- Be extremely careful servicing the shaft encoders on Floodgates No. 1 and No. 2. They are about $15 \mathrm{ft}$ above the upper deck of the intake structure and require a ladder for access. If someone servicing the shaft encoders were to fall off the ladder, he or she might go over the railing and into the lake or onto the rocks below.

- The previous comment also is applicable for servicing the antenna for the Sutron 8210 datalogger. Although the antenna is not as high as the shaft encoders, it still is dangerous to service them from a ladder.

- Be careful backing out of the driveway to the gate-sensing equipment. It is difficult to see traffic coming from the south because a hill creates a blind spot. It is safer to back out and travel south and then turn around to travel north. 
Figure 61. Somerville Lake Sutron 8210 wiring panel.
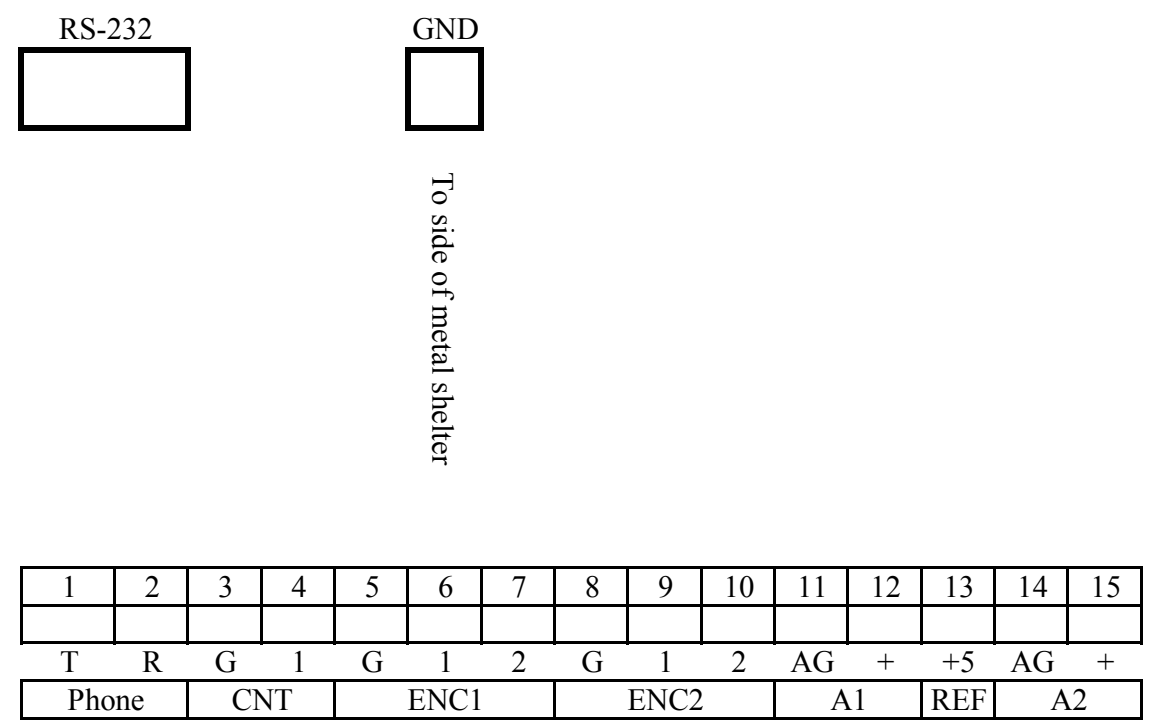

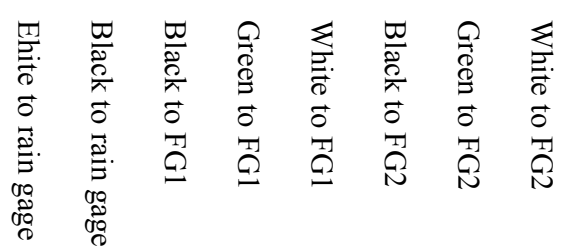

Note: FG1, Floodgate No. 1 FG2, Floodgate No. 2.

\begin{tabular}{|c|c|c|c|c|c|c|c|c|c|c|c|c|c|c|}
\hline \multicolumn{2}{|c|}{ Ext Batt } & \multicolumn{2}{|c|}{ RS485 } & \multicolumn{3}{|c|}{ SDI-12 } & \multicolumn{3}{|c|}{ SDI-12 } & \multicolumn{5}{|c|}{ Digital Output } \\
\hline$\overline{\mathrm{G}}$ & + & $\overline{\mathrm{A}}$ & $\bar{B}$ & $\overline{\mathrm{G}}$ & + & $\bar{D}$ & $\bar{G}$ & + & $\bar{D}$ & 1 & 2 & 3 & 4 & 5 \\
\hline & & & & & & & & & & & & & & \\
\hline 1 & 2 & 3 & 4 & 5 & 6 & 7 & 8 & 9 & 10 & 11 & 12 & 13 & 14 & 15 \\
\hline
\end{tabular}

\begin{tabular}{|c|c|c|c|}
\hline 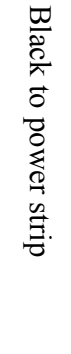 & 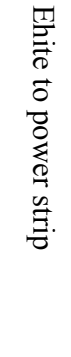 & 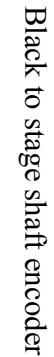 & $\begin{array}{l}0 \\
0 \\
0 \\
0 \\
0 \\
00 \\
0 \\
0 \\
0 \\
0 \\
0 \\
0 \\
0 \\
0\end{array}$ \\
\hline
\end{tabular}

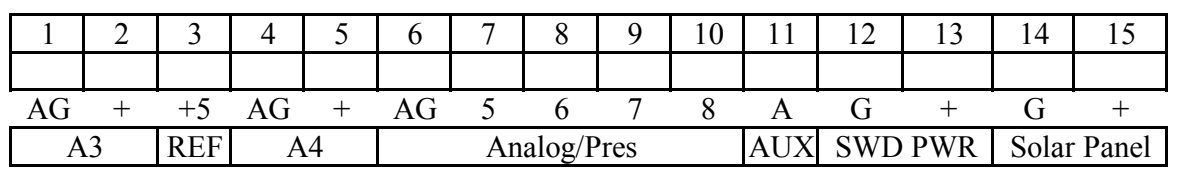

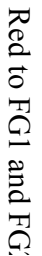


Figure 62. Somerville Lake equipment wiring diagram.

\begin{tabular}{|l|l}
\hline Stage shaft encoder & $\begin{array}{l}\text { Green to Sutron } \\
\text { Red to Sutron }\end{array}$ \\
& Black to Sutron
\end{tabular}

$\longrightarrow$ Rain gage $\longrightarrow \quad \begin{aligned} & \text { Black to Sutron } \\ & \end{aligned}$
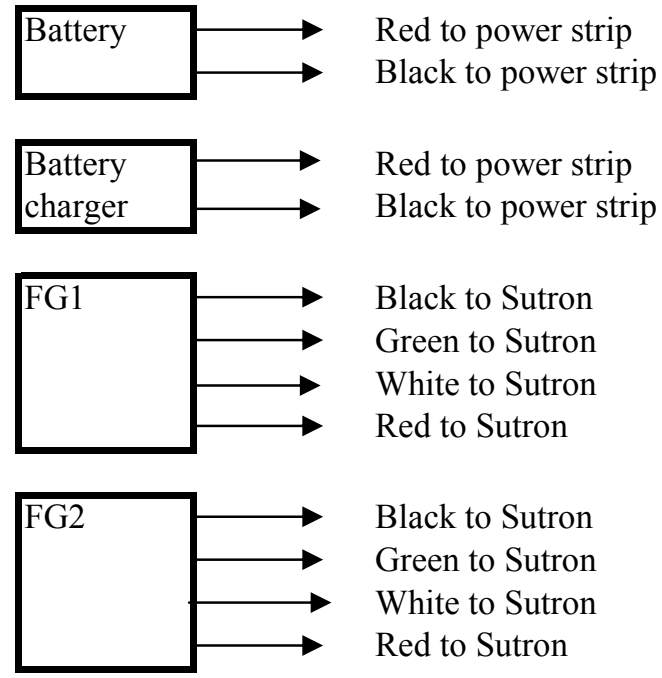

Note: $\quad$ FG1, Floodgate No. 1.

FG2, Floodgate No. 2. 


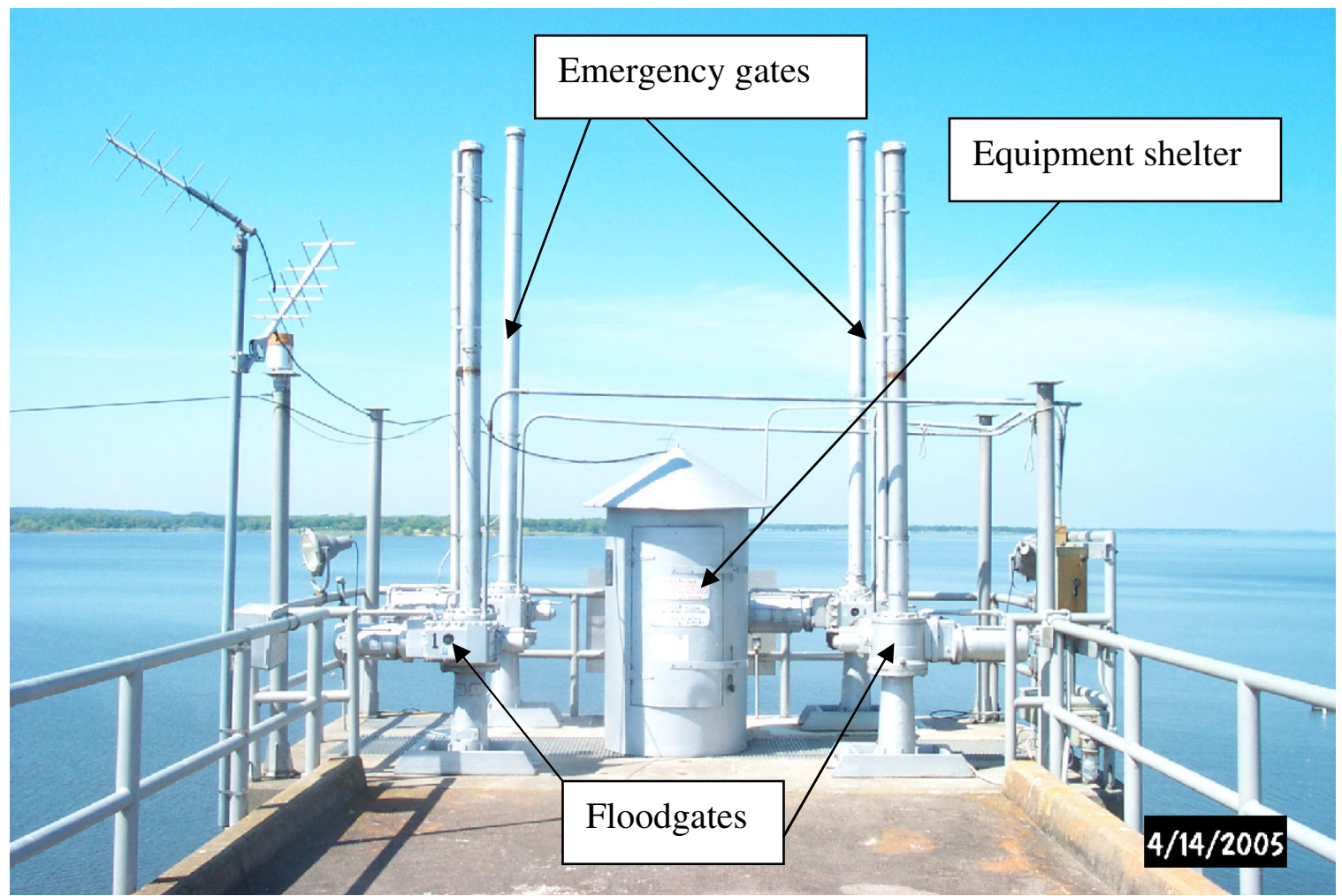

Figure 63. Gate-sensing equipment at Somerville Lake. 


\section{Somerville Lake Sutron 8210 Setup File (LAKSOMER.SET)}

; 8210/8200 ASCII setup file, can be converted back to a .SET file with WSETMGR.EXE

;

; MAIN SETUP

;

Setup_Version $=$ V6X

Unit_ID=LAKSOMER

Measurement_Interval=00:15:00

Sampling_Interval=00:00:00

Measurement_Time $=00: 00: 00$

Sampling_Time $=00: 00: 00$

Switched_Power_Time $=00: 00: 00$

Samples_to_Average $=0$

Measurements_per_Log=1

Switched_Power_Mode $=\mathrm{ON}$

Recording $=\mathrm{ON}$

Basic_Run_Interval=00:00:00

Basic_Run_Time $=00: 00: 00$

Password=

Number_Resets $=2$

Log_Size $=124928$

Rom_Checksum=57134

;

; EEROM SETUP

Serial_Port_Mode=USER

User_Baud_Rate $=9600$

Radio_Baud_Rate $=1200$

Com_Baud_Rate $=9600$

Transfer_Baud_Rate $=9600$

SDI_Baud_Rate $=1200$

Enter_Key_Reqd=OFF

Log_Dump_Mode=ALL-BIN

User_Time_Limit=6666

Power_Delay $=1$

Analog_Delay $=5$

Pressure_Delay $=5$

Auto_Startup_Keys=

Time_Format=NORMAL

Date_Format=MDY

Term_Xmit_Delay $=0$

Basic_Size $=1$

Amp_Gain=1.0

;

; PROTOCOL SETUP

Master_Name=

Carrier_Delay $=7$

Com_Port_Mode=

Reply_Delay $=0$

Ack_Delay $=100$ 


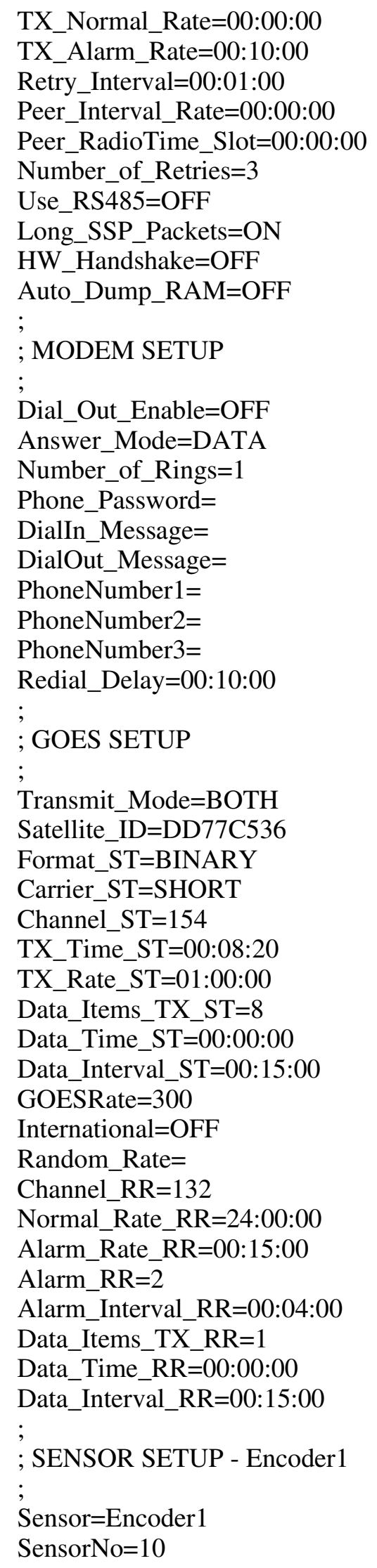




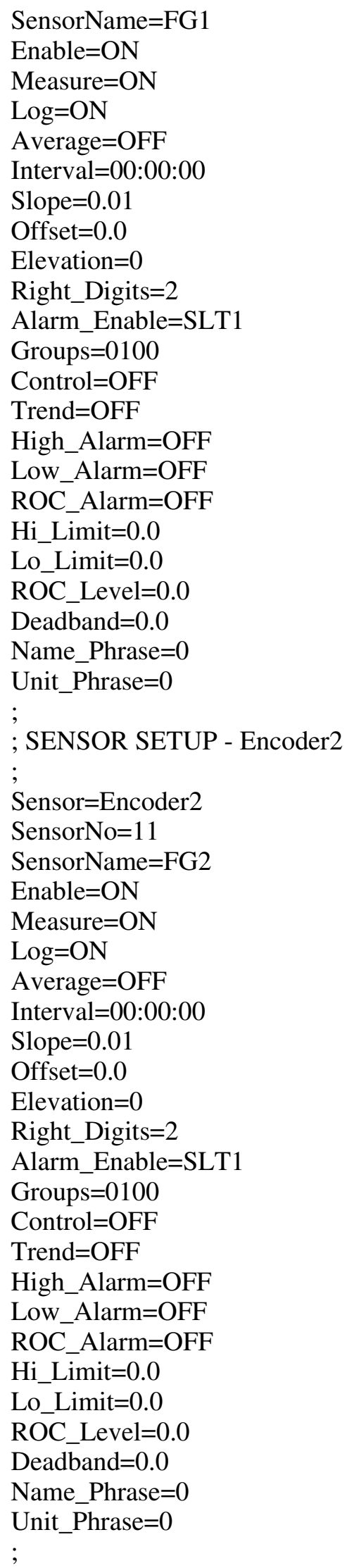




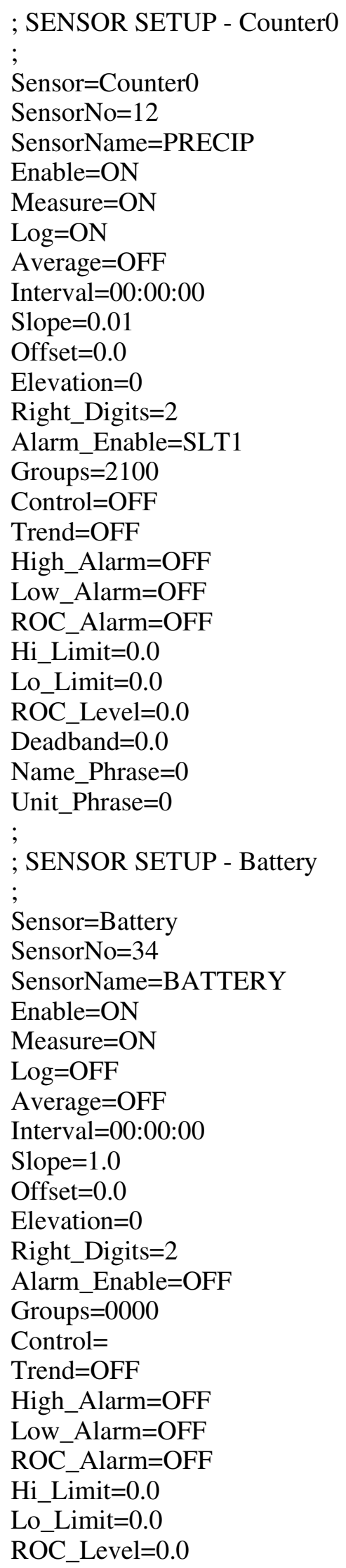


Deadband $=0.0$

Name_Phrase $=0$

Unit_Phrase $=0$

;

; SENSOR SETUP - SDI0_1

Sensor=SDI0_1

SensorNo $=68$

SensorName $=$ ELEV

Enable $=\mathrm{ON}$

Measure $=\mathrm{ON}$

$\mathrm{Log}=\mathrm{ON}$

Average $=\mathrm{OFF}$

Interval=00:00:00

Slope $=1.0$

Offset $=200.0$

Elevation $=0$

Right_Digits=2

Alarm_Enable=SLT1

Groups $=0120$

Control=OFF

Trend $=\mathrm{OFF}$

High_Alarm=OFF

Low_Alarm $=\mathrm{OFF}$

ROC_Alarm $=\mathrm{OFF}$

Hi_Limit $=0.0$

Lo_Limit $=0.0$

ROC_Level $=0.0$

Deadband $=0.0$

Name_Phrase $=0$

Unit_Phrase $=0$ 


\section{Stillhouse Hollow Lake Near Belton, Tex.}

\section{Location}

Lat $31^{\circ} 01^{\prime} 20^{\prime \prime}$, long $97^{\circ} 31^{\prime} 57^{\prime \prime}$, Bell County, in intake structure of Stillhouse Hollow Dam on the Lampasas River, 5.0 mi southwest of Belton, and 16.0 mi upstream from mouth.

\section{Road Log}

From USGS Texas WSC-Fort Worth, travel I-35 south about 128 mi to Belton. Take the US 190 west exit (Killeen/Fort Hood) and travel west 2.0 mi to FM 1670 and Stillhouse Hollow Dam exit. Take FM 1670 south 2.5 mi to the USACE office. The intake structure is off FM 1670, about $1.0 \mathrm{mi}$ from the USACE office, and in the middle of the dam.

\section{Access}

Before visiting the site, call the Stillhouse Hollow Dam USACE office at 254939-2461 to let them know you will be servicing the site. The USACE office has a key to the main gate on the walkway to the intake structure and the main door. A staff member will escort you and give you access. If you need to descend below the floor where the Sutron datalogger is located to access the gate-sensing equipment, a USACE staff member will need to escort you down the elevator.

\section{Equipment Description}

Refer to table 13, "Stillhouse Hollow Lake equipment inventory," for a complete list of equipment and to figures 64-68 for equipment wiring diagrams and photographs of equipment. Two main floodgates and two emergency gates are raised and lowered by hydraulic pistons. Floodgates No. 1 and No. 2 are labeled numerals 1 and 2 and the emergency gates are labeled E-1 and E-2. Floodgates No. 1 and No. 2 will be used in this description to be consistent with naming conventions at other dams. Similarly, Emergency Gates No. 1 and No. 2 will be used when referring to the emergency gates. All of the gate-sensing equipment is located on the lower level of the intake structure, which is about $100 \mathrm{ft}$ below the upper level and accessible by a small elevator. Floodgate No. 1 is on the right side of the intake structure (facing upstream) and Floodgate No. 2 is on the left. Similarly, Emergency Gates No. 1 and No. 2 are located on the right and left side (facing upstream), respectively, of the intake structure.

The floodgates and emergency gates use Whessoe Varec 2500B automatic tank level gages to indicate the position of the gates. Position is relayed to the Sutron 8210 datalogger with Whessoe Varec 8200 series liquid level transmitters. A steel tape runs from the top of each floodgate and emergency gate to the 2500B tank level gage, where it wraps around a storage drum connected to a Neg'ator constant-force spring motor. The Neg' ator spring motor consists of a prestressed stainless steel tape that is formed into a coil and stored on a small storage drum. The free end of the coil is wrapped backwards onto a larger output drum and then fastened to the drum. When the steel tape connected 
to the top of the gate winds up in the 2500B gage as the gate is raised, the tape of the Neg'ator spring motor will wind up onto the small storage drum. Conversely, when the steel tape connected to the top of the gate unwinds as the gate is lowered, the tape of the Neg'ator spring motor will unwind from the small storage drum and wind up on the output drum. In both instances the Neg' ator spring motor functions to provide a constant amount of force (torque) on the steel tape attached to the gate regardless of the amount of deflection. The movement of the small storage drum rotates a shaft inside the 8200 position transmitter. The shaft is coupled to a worm gear, which in turn drives the shaft of a potentiometer. Rotation of the shaft causes a change in the output current of the transmitter. The variations in current output are carried to the Sutron 8210 datalogger by two wires. At the datalogger, the current is passed through a resistor so the voltage can be measured. The output current of the transmitters varies from 4 to $20 \mathrm{~mA}$.

Gate-sensing equipment serves as a reference for the two floodgates at Stillhouse Hollow Dam. The steel tape from the Whessoe Varec gages is attached to a rod that comes out of the top of the hydraulic cylinders. A pointer attached to the rod indicates gate position on a ruler. These are also located on the lower level of the intake structure.

The Sutron 8210 datalogger is powered by a 12-VDC battery, which is charged by an automatic sealed lead-acid battery charger connected to a $120-\mathrm{VAC}$ wall outlet. The position transmitters are powered by 24 VDC from a transformer inside the equipment box below the Sutron 8210 . Varec offers an onboard power source that would eliminate the transformer and AC power inside the equipment box. Instead, AC power would run directly to the position transmitter and be converted to 24 VDC by an internal transformer.

The setup file (STIT2.SET) for the datalogger is stored on the RAM card that is kept inside the Sutron equipment box. A hard copy of the setup file is also kept in the station folder.

The positions of both floodgates and emergency gates are transmitted by satellite and posted on the USACE Web site (http://www.swf-wc.usace.army.mil) under Daily Reports/Gate Sensor Report. The USACE reports hourly data; however, the Sutron datalogger measures and records the gate position for the four gates every 15 minutes.

Floodgates No. 1 and No. 2 are SERGATE1 and SERGATE2, respectively, and Emergency Gates No. 1 and No. 2 are EMRGATE1 and EMRGATE2, respectively, in the Sutron setup file.

\section{Operation and Maintenance}

Operation and maintenance information for the equipment at Stillhouse Hollow Dam includes descriptions of different procedures required to maintain equipment such as routine inspections, recalibration of Floodgates No. 1 and No. 2 and Emergency Gates No. 1 and No. 2, and annual inspections. The purpose of a site visit and the actions taken should be documented in the logbook kept near the datalogger. Include the date, time, actions, and personnel conducting the site visit in the logbook. This section lists some of the potential problems that might occur with the equipment in service and possible solutions to the problems. Refer to the Operations Manuals for the individual pieces of equipment when further detail is required. The information included here is basic operations and maintenance information. 
For each visit to the site, personnel should carry all of the necessary tools required to service the equipment. The tools required to perform all of the tasks listed include the following:

- Screwdrivers, flat and Phillips head

- Crescent wrench, 10-in.

- Stepladder, 10-ft.

- Electrical tape

- Digital multimeter

- Pliers

- Ruler

- Laptop computer capable of connecting (with RS-232 port and 9-pin cable) to Sutron 8210

- Sutron 8210 Operations Manual

- Whessoe Varec 2500 Installation and Operations Manual

- Whessoe Varec 8200 Installation and Operations Manual

- Battery load tester

- Spare battery

- Flashlight

- Silicone sealant

- Rope, 50-ft

\section{Procedures during a routine inspection}

- Check the enclosure to the Sutron 8210 datalogger for damage and moisture. If moisture is entering the enclosure, seal any openings with silicone.

- Scroll through the VIEW DATA/LIVE READINGS menu and check that the datalogger is making measurements.

- Check the antennas (data and GPS) and make sure connections are secure and waterproofed. Replace electrical tape around connections if old and brittle.

- Check the battery voltage under the LIVE READINGS menu on the Sutron 8210.

- If voltage is low (less than $11.5 \mathrm{~V}$ ), test the battery with a load tester and make sure the voltage remains above the recommended voltage specific to the load tester being used. Replace battery as needed.

- Remove drain plug on bottom of position sensor and allow water to drain out.

- Verify that the Whessoe Varec position sensors and the Sutron 8210 datalogger measure the same values (within $0.01 \mathrm{ft}$ ) for the positions of both floodgates and emergency gates. Next, compare the values from the position sensors and the datalogger to the pointer reading. If the position sensors and datalogger values are within $0.01 \mathrm{ft}$ of each other and within $0.05 \mathrm{ft}$ of the pointer reading, no action is required. If the position sensors and the datalogger values differ by more than $0.01 \mathrm{ft}$ or by more than $0.05 \mathrm{ft}$ of the pointer reading, refer to the recalibration procedures.

- Before leaving the site, make sure the Sutron 8210 is reading ON \& TX under RECORDING. 


\section{Procedures to recalibrate Floodgates No. 1 and No. 2 and Emergency Gates No. 1 and No. 2}

- Completely lower the gate requiring calibration and set the Whessoe Varec position sensor to measure 0.00. To do this, refer to the Whessoe Varec 2500 Installation and Operations Manual (p. 33 and 34). If the position sensor measures 0.00 when the gate is lowered completely, only the Sutron requires calibration.

- Caution: Before executing this procedure, make sure the emergency gates are closed. To calibrate the Sutron after setting the Whessoe Varec unit to measure 0.00 , first record the current slope and offset for the gate being calibrated. Next, set the slope and the offset to 1.00 and 0.00 , respectively. With the gate still completely closed, scroll down to SYSTEM SETUP. Press the right arrow once and scroll down to CONFIG SENSORS. Press the right arrow once and scroll down to the gate that is being calibrated. With the correct gate selected, press the right arrow once and scroll down to VALUE. Enter the correct value, which would be 0.00 , then press the SET button. Next, open the gate as much as possible so that the instrument will be calibrated over the entire range of gate positions. With the gate open as much as possible, enter the value from the Whessoe Varec dial into the VALUE field and press the SET button. The datalogger will calculate the slope and the offset from the two known positions entered.

- Verify that the Whessoe Varec position sensor and the Sutron 8210 datalogger are now measuring the same position with the gate open as much as possible. Also verify that the measurements are within $0.05 \mathrm{ft}$ of the pointer reading. After verification, close the gate completely and check that both measure 0.00 with the gate completely closed. If so, the calibration is complete; if not, perform the calibration again.

- Whenever a change is made to the setup file in the datalogger, download the new file to the RAM card kept at the site. To do this, insert the RAM card into the socket and turn on the 8210. Scroll down to the DUMP DATA menu. Press the right arrow once, then press the down arrow until WRITE CARD SETUP is displayed. Press the SET button and wait for the file to be transferred from the datalogger to the RAM card. To transfer the file from the RAM card to the datalogger, scroll down to the DUMP DATA menu. Press the right arrow once, then press the down arrow until READ CARD SETUP is displayed. Press the right arrow to access the setup file. Transfer the selected file to the datalogger by pressing the SET button.

- Record changes to the slope or the offset in the logbook.

\section{Procedures during an annual inspection}

- During an inspection the emergency gates are lowered, and the floodgates are raised all the way up and cleaned and inspected. As the gates are lowered after being serviced, check that the position sensors and datalogger measure the same values. If not, follow the instructions to recalibrate the instruments.

- After the inspection, follow all of the procedures during a routine inspection. 
Table 13. Stillhouse Hollow Lake equipment inventory.

[See table of contents for abbreviated units; --, not available or not applicable]

\begin{tabular}{|c|c|c|c|c|}
\hline Item no. & Item description & Manufacturer & Model no. & Remarks \\
\hline 1. & Floodgate No. 1 position sensor & Whessoe Varec & $2500 \mathrm{~B}$ & $\begin{array}{l}\text { Gate is SERGATE1 in Sutron setup and equipment is labeled } \\
\text { with numeral } 1\end{array}$ \\
\hline 2. & Floodgate No. 1 position transmitter & Whessoe Varec & 8200 & $\begin{array}{l}\text { Analog transmitter with current output of } 4 \text { to } 20 \mathrm{~mA} \text { and input } \\
\text { of } 15 \text { to } 48 \mathrm{VDC}\end{array}$ \\
\hline 3. & $\begin{array}{l}\text { Wire for Floodgate No. } 1 \text { position } \\
\text { transmitter }\end{array}$ & -- & -- & $175 \mathrm{ft}$ of $18 \mathrm{AWG} / 2$ wires \\
\hline 4. & Floodgate No. 2 position sensor & Whessoe Varec & 2500B & $\begin{array}{l}\text { Gate is SERGATE2 in Sutron setup and equipment is labeled } \\
\text { with numeral } 2\end{array}$ \\
\hline 5. & Floodgate No. 2 position transmitter & Whessoe Varec & 8200 & $\begin{array}{l}\text { Analog transmitter with current output of } 4 \text { to } 20 \mathrm{~mA} \text { and input } \\
\text { of } 15 \text { to } 48 \mathrm{VDC}\end{array}$ \\
\hline 6. & $\begin{array}{l}\text { Wire for Floodgate No. } 2 \text { position } \\
\text { transmitter }\end{array}$ & -- & -- & $175 \mathrm{ft}$ of $18 \mathrm{AWG} / 2$ wires \\
\hline 7. & $\begin{array}{l}\text { Emergency Gate No. } 1 \text { position } \\
\text { sensor }\end{array}$ & Whessoe Varec & $2500 \mathrm{~B}$ & $\begin{array}{l}\text { Gate is EMRGATE1 in Sutron setup and equipment is labeled E- } \\
1\end{array}$ \\
\hline 8. & $\begin{array}{l}\text { Emergency Gate No. } 1 \text { position } \\
\text { transmitter }\end{array}$ & Whessoe Varec & 8200 & $\begin{array}{l}\text { Analog transmitter with current output of } 4 \text { to } 20 \mathrm{~mA} \text { and input } \\
\text { of } 15 \text { to } 48 \mathrm{VDC}\end{array}$ \\
\hline 9. & $\begin{array}{l}\text { Wire for Emergency Gate No. } 1 \\
\text { position transmitter }\end{array}$ & -- & -- & $175 \mathrm{ft}$ of $18 \mathrm{AWG} / 2$ wires \\
\hline 10. & $\begin{array}{l}\text { Emergency Gate No. } 2 \text { position } \\
\text { sensor }\end{array}$ & Whessoe Varec & $2500 \mathrm{~B}$ & $\begin{array}{l}\text { Gate is EMRGATE2 in Sutron setup and equipment is labeled E- } \\
2\end{array}$ \\
\hline 11. & $\begin{array}{l}\text { Emergency Gate No. } 2 \text { position } \\
\text { transmitter }\end{array}$ & Whessoe Varec & 8200 & $\begin{array}{l}\text { Analog transmitter with current output of } 4 \text { to } 20 \mathrm{~mA} \text { and input } \\
\text { of } 15 \text { to } 48 \text { VDC }\end{array}$ \\
\hline 12. & $\begin{array}{l}\text { Wire for Emergency Gate No. } 2 \\
\text { position transmitter }\end{array}$ & - & -- & $175 \mathrm{ft}$ of $18 \mathrm{AWG} / 2$ wires \\
\hline 13. & Stage shaft encoder & Handar & $436 \mathrm{~A}$ & -- \\
\hline 14. & Rain gage & Texas Electronics, Inc. & TR-525I & -- \\
\hline 15. & Datalogger & Sutron & 8210 & -- \\
\hline 16. & Battery & Xtreme Plus VRLA & XPA 12-55P & $12-\mathrm{V}, 55.0-\mathrm{A}-\mathrm{h}$ battery for Sutron 8210 \\
\hline 17. & Battery charger & Batt Cat 1 & -- & -- \\
\hline 18. & Transformer & Power-One & HB24-1.2-A & Converts $120 \mathrm{VAC}$ to $24 \mathrm{VDC}$ for power to position transmitters \\
\hline 19. & Antenna & Synergetics & $18 \mathrm{~B}$ & Mounted to shelter on upper deck of intake structure \\
\hline 20. & Antenna cable & Alpha Wire-J & RG 8/U & 41-ft cable from Sutron 8210 to antenna \\
\hline 21. & Data transmitter & Sutron & Satlink & 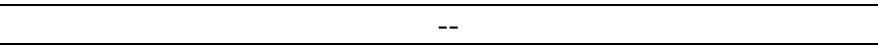 \\
\hline 22. & GPS antenna & -- & -- & -- \\
\hline 23. & GPS antenna cable & Times Microwave Systems & 68999 & 41-ft cable from Sutron 8210 to antenna \\
\hline
\end{tabular}




\section{Job Hazard Analysis}

Required protective clothing, safety equipment, and supplies: Personal flotation device (PFD), reflective vest, gloves, steel-toed shoes, waders, cell phone, first aid kit, fire extinguisher, rotating or strobe type emergency lights, drinking water.

\begin{tabular}{|c|c|c|}
\hline $\begin{array}{l}\text { Sequence of basic } \\
\text { job steps }\end{array}$ & $\begin{array}{l}\text { Potential } \\
\text { accident or hazard }\end{array}$ & Recommended safe job procedures \\
\hline $\begin{array}{l}\text { Upon job } \\
\text { assignment }\end{array}$ & $\begin{array}{l}\text { Water-related accident or } \\
\text { injury }\end{array}$ & $\begin{array}{l}\text { Employees working in and around water must receive } \\
\text { training specified in WRD Memo 2000.10, "Policy for } \\
\text { safety training associated with over-water activities." }\end{array}$ \\
\hline $\begin{array}{l}\text { Loading and } \\
\text { unloading } \\
\text { equipment }\end{array}$ & $\begin{array}{l}\text { Pinched fingers, mashed } \\
\text { toes, or strained back }\end{array}$ & $\begin{array}{l}\text { Be aware of hand placement. Wear protective gloves and } \\
\text { steel-toed shoes. Use proper lifting techniques. Lift with } \\
\text { legs. Use extra caution lifting heavy sounding weights. }\end{array}$ \\
\hline $\begin{array}{l}\text { Driving to and } \\
\text { returning from work } \\
\text { site }\end{array}$ & $\begin{array}{l}\text { Traffic accidents, vehicle } \\
\text { flooding, or drowning }\end{array}$ & $\begin{array}{l}\text { Drivers of USGS vehicles must have Drivers Safety } \\
\text { Training (SM 445-2-H, chap. 16). Be alert to traffic in } \\
\text { area, obey all traffic laws, and reduce speed when weather } \\
\text { conditions are bad. Do not drive across flooded highways } \\
\text { unless water depth and bridge conditions are known to be } \\
\text { safe. }\end{array}$ \\
\hline Parking vehicle & $\begin{array}{l}\text { Personal and vehicle } \\
\text { safety when exiting } \\
\text { vehicle in traffic; bank } \\
\text { collapse or bridge failure }\end{array}$ & $\begin{array}{l}\text { Use rotating or strobe emergency lights, follow site } \\
\text { traffic-control plan, wear DOT Type III reflective vest } \\
\text { when working in or near roadway. Park away from stream } \\
\text { at a safe distance from banks. }\end{array}$ \\
\hline $\begin{array}{l}\text { Set up traffic- } \\
\text { control equipment }\end{array}$ & $\begin{array}{l}\text { Personal and public } \\
\text { safety }\end{array}$ & $\begin{array}{l}\text { Employees working in or near roadways must have Work } \\
\text { Zone Traffic-Control Safety Training. Remain alert to } \\
\text { traffic conditions. }\end{array}$ \\
\hline $\begin{array}{l}\text { Working at field } \\
\text { site }\end{array}$ & Drowning & $\begin{array}{l}\text { Employees are required to wear a PFD when working in, } \\
\text { on, or over any body of water. There are no exemptions } \\
\text { for employees in the Texas WSC. PFDs will be } \\
\text { international orange in color and equipped with reflective } \\
\text { tape in accordance with } 46 \text { CFR } 25.25-15 \text {. Self-inflating } \\
\text { PFDs are not to be worn by employees who have not had } \\
\text { In-Water Safety Training. }\end{array}$ \\
\hline $\begin{array}{l}\text { Working at field } \\
\text { site }\end{array}$ & Trips, slips, and falls & $\begin{array}{l}\text { Follow path clear of obstructions and with minimal slope; } \\
\text { avoid slippery surfaces. Walk cautiously on steep slopes } \\
\text { or paths with loose material. Use appropriate footwear for } \\
\text { the terrain and conditions. Follow the safest, not the } \\
\text { fastest path! }\end{array}$ \\
\hline $\begin{array}{l}\text { Working at field } \\
\text { site }\end{array}$ & $\begin{array}{l}\text { Dehydration, heat } \\
\text { exhaustion, heat stroke, } \\
\text { or sunburn }\end{array}$ & $\begin{array}{l}\text { Drink plenty of water or electrolyte drink. Wear } \\
\text { appropriate clothing. Take occasional breaks and watch } \\
\text { for symptoms of heat exhaustion. Use sun block. }\end{array}$ \\
\hline $\begin{array}{l}\text { Working at field } \\
\text { site }\end{array}$ & Hypothermia or frostbite & $\begin{array}{l}\text { Wear foul-weather gear during winter months. Keep } \\
\text { clothing dry. }\end{array}$ \\
\hline $\begin{array}{l}\text { Working at field } \\
\text { site }\end{array}$ & Snake bites & $\begin{array}{l}\text { Wear appropriate foot and leg protection. Watch path } \\
\text { ahead. Keep area around gage clear of brush. If bitten, } \\
\text { seek immediate medical help. }\end{array}$ \\
\hline
\end{tabular}




\begin{tabular}{|l|l|l|}
\hline $\begin{array}{l}\text { Working at field } \\
\text { site }\end{array}$ & Poisonous plants & $\begin{array}{l}\text { Know how to identify poisonous plants. Wear protective } \\
\text { clothing. Wash and flush exposed areas immediately with } \\
\text { cold water. Wash with degreasing type soap and flush } \\
\text { from skin. Seek medical attention for severe reactions. }\end{array}$ \\
\hline Entering gage house & $\begin{array}{l}\text { Infectious disease or } \\
\text { airborne pollutants; risk } \\
\text { of hantavirus exposure }\end{array}$ & $\begin{array}{l}\text { Watch for bats or rodent nests and droppings. If nest or } \\
\text { droppings are present, do not disturb dust. Gage should be } \\
\text { periodically cleaned to minimize risk of exposure. See } \\
\text { WRD memo dated 10/28/97, "Preventing hantavirus } \\
\text { disease," and OP memo dated 01/94, "Instructions for } \\
\text { preventing hantavirus disease." }\end{array}$ \\
\hline Entering gage house & Insect or snake bites & $\begin{array}{l}\text { Inspect in and around shelter for harmful insects. Use } \\
\text { wasp or insect spray. Inspect in and around shelter for } \\
\text { snakes prior to entry. }\end{array}$ \\
\hline
\end{tabular}

\section{Site-Specific Job Hazards}

The items listed are safety issues specific to this site that deserve special emphasis.

- Descend in the elevator to the gate-sensing equipment with USACE staff and notify other staff at office when you expect to be done. Instruct staff remaining above that you will call them when you are out to prevent being stranded below for too long if elevator malfunctions. Gate-sensing equipment is about $100 \mathrm{ft}$ below the upper deck.

- Be extremely careful descending the ladder to get to the floor below the floor where the elevator stops to service or check the gate-sensing equipment. The difference between the two floors is about $25 \mathrm{ft}$. Before descending, put on a harness and clip into the carabineer. The harness is kept inside the silver box next to the Sutron 8210 on the upper level. Lower any tools or other equipment (such as a ladder) with a rope. Descend the steps slowly. The cable connected to the carabineer is designed so that if someone were to fall, the cable would stop releasing and prevent a fall much like a seatbelt works in an automobile when pulled suddenly. Don't forget to attach the cable to the ladder at the bottom so it will be available when ascending to the upper level.

- Be careful working in or around the Sutron 8210. The transformer in the box below the Sutron 8210 is wired with 120 VAC. 
Figure 64. Stillhouse Hollow Lake Sutron 8210 wiring panel.

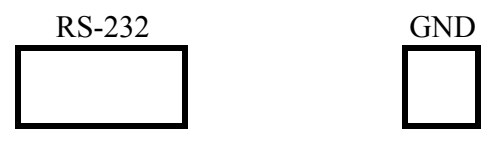

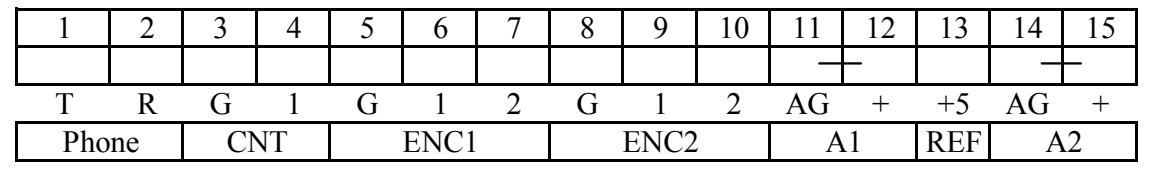

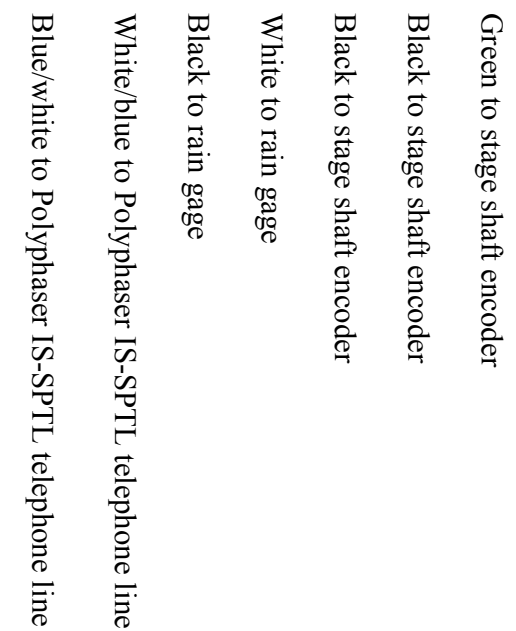

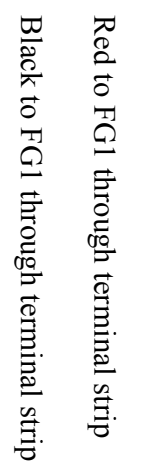

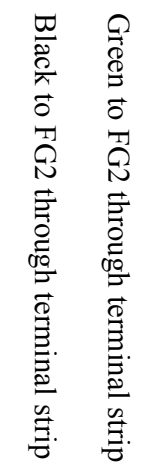

Note: FG1, Floodgate No. 1

FG2, Floodgate No. 2.

E1, Emergency Gate No. 1

E2, Emergency Gate No. 2.

+ denotes a resistor between the two ports of the Sutron

\begin{tabular}{|c|c|c|c|c|c|c|c|c|c|c|c|c|c|c|}
\hline \multicolumn{2}{|c|}{ Ext Batt } & \multicolumn{2}{|c|}{ RS485 } & \multicolumn{3}{|c|}{ SDI-12 } & \multicolumn{3}{|c|}{ SDI-12 } & \multicolumn{5}{|c|}{ Digital Output } \\
\hline$\overline{\mathrm{G}}$ & + & $\overline{\mathrm{A}}$ & $\bar{B}$ & $\overline{\mathrm{G}}$ & + & $\bar{D}$ & $\bar{G}$ & + & $\bar{D}$ & 1 & 2 & 3 & 4 & 5 \\
\hline & & & & & & & & & & & & & & \\
\hline 1 & 2 & 3 & 4 & 5 & 6 & 7 & 8 & 9 & 10 & 11 & 12 & 13 & 14 & 15 \\
\hline
\end{tabular}

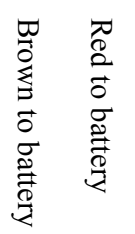

\begin{tabular}{|c|c|c|c|c|c|c|c|c|c|c|c|c|c|c|}
\hline 1 & 2 & 3 & 4 & 5 & 6 & 7 & 8 & 9 & 10 & 11 & 12 & 13 & 14 & 15 \\
\hline+ & & - & & & & & & & & & & \\
\hline $\mathrm{AG}+$ & +5 & $\mathrm{AG}+$ & $\mathrm{AG}$ & 5 & 6 & 7 & 8 & $\mathrm{~A}$ & $\mathrm{G}$ & + & $\mathrm{G}$ & + \\
\hline $\mathrm{A} 3$ & $\mathrm{REF}$ & $\mathrm{A} 4$ & \multicolumn{6}{c}{ Analog/Pres } & $\mathrm{AUX}$ & SWD PWR & Solar Panel \\
\hline
\end{tabular}

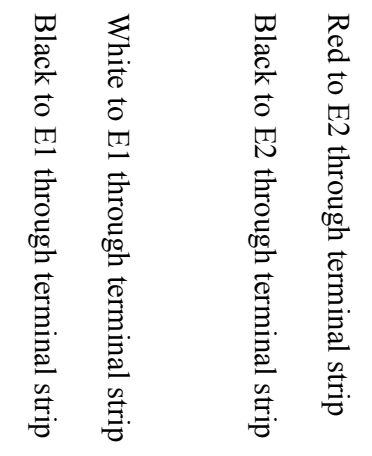

2
0
0
0
0
0
010
0
0
0
0
0
0
0
0
0
0
0 
Figure 65. Stillhouse Hollow Lake equipment wiring diagram.
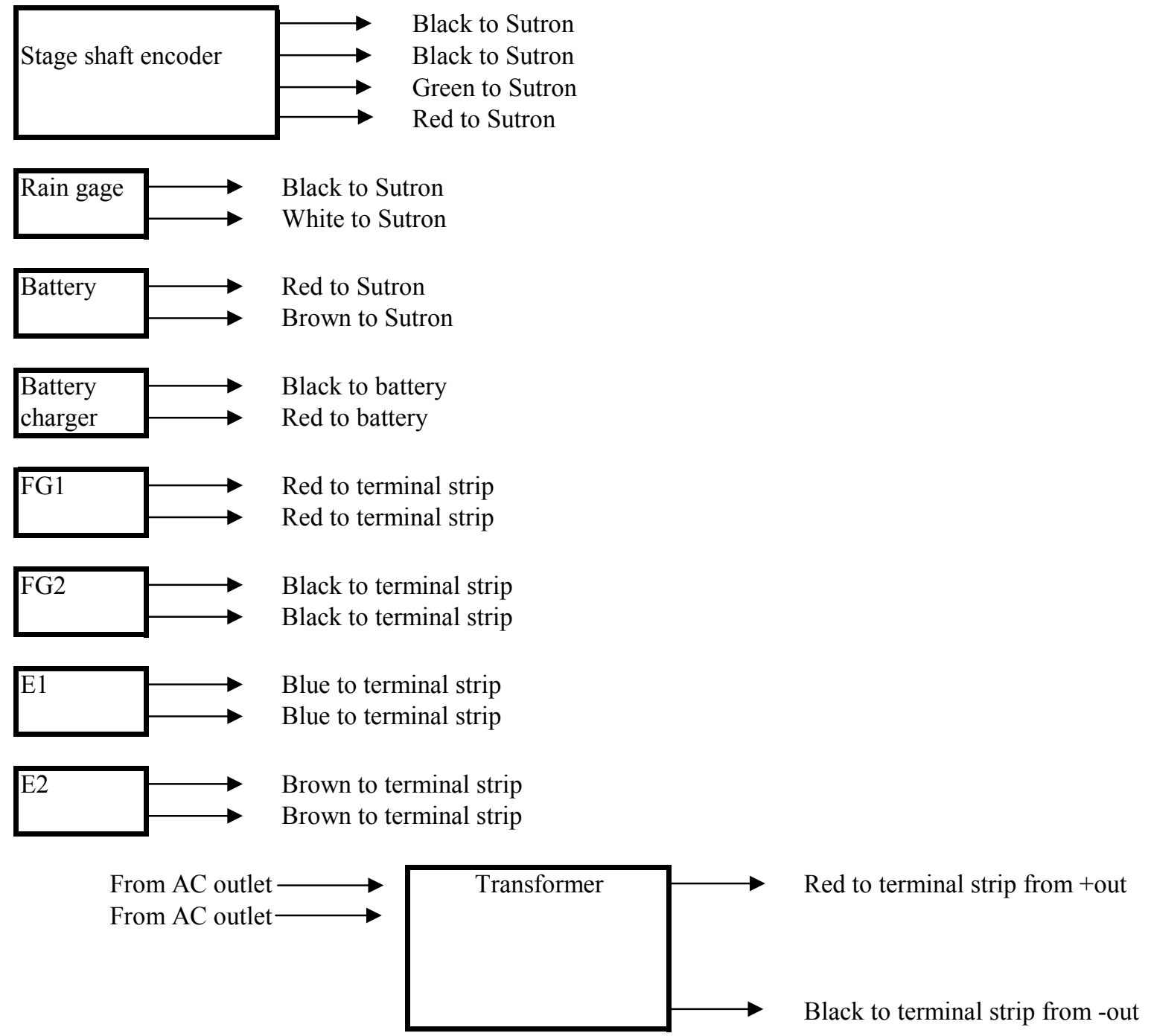

Note: $\quad$ FG1, Floodgate No. 1.

FG2, Floodgate No. 2.

E1, Emergency Gate No. 1.

E2, Emergency Gate No. 2. 
Figure 65. Stillhouse Hollow Lake equipment wiring diagram--Continued.

\section{Terminal strip}

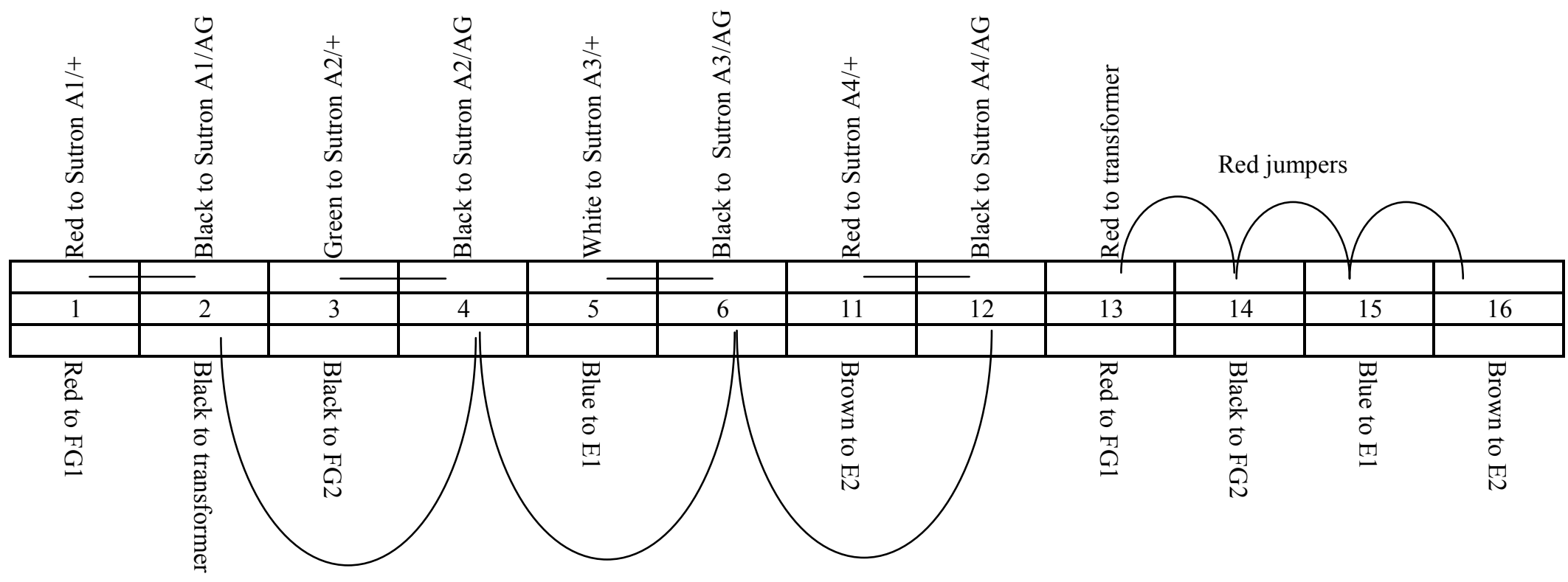

Note: $\quad$ FG1, Floodgate No. 1

FG2, Floodgate No. 2.

E1, Emergency Gate No. 1.

E2, Emergency Gate No. 2.

denotes a resistor between the two ports of the terminal strip. 


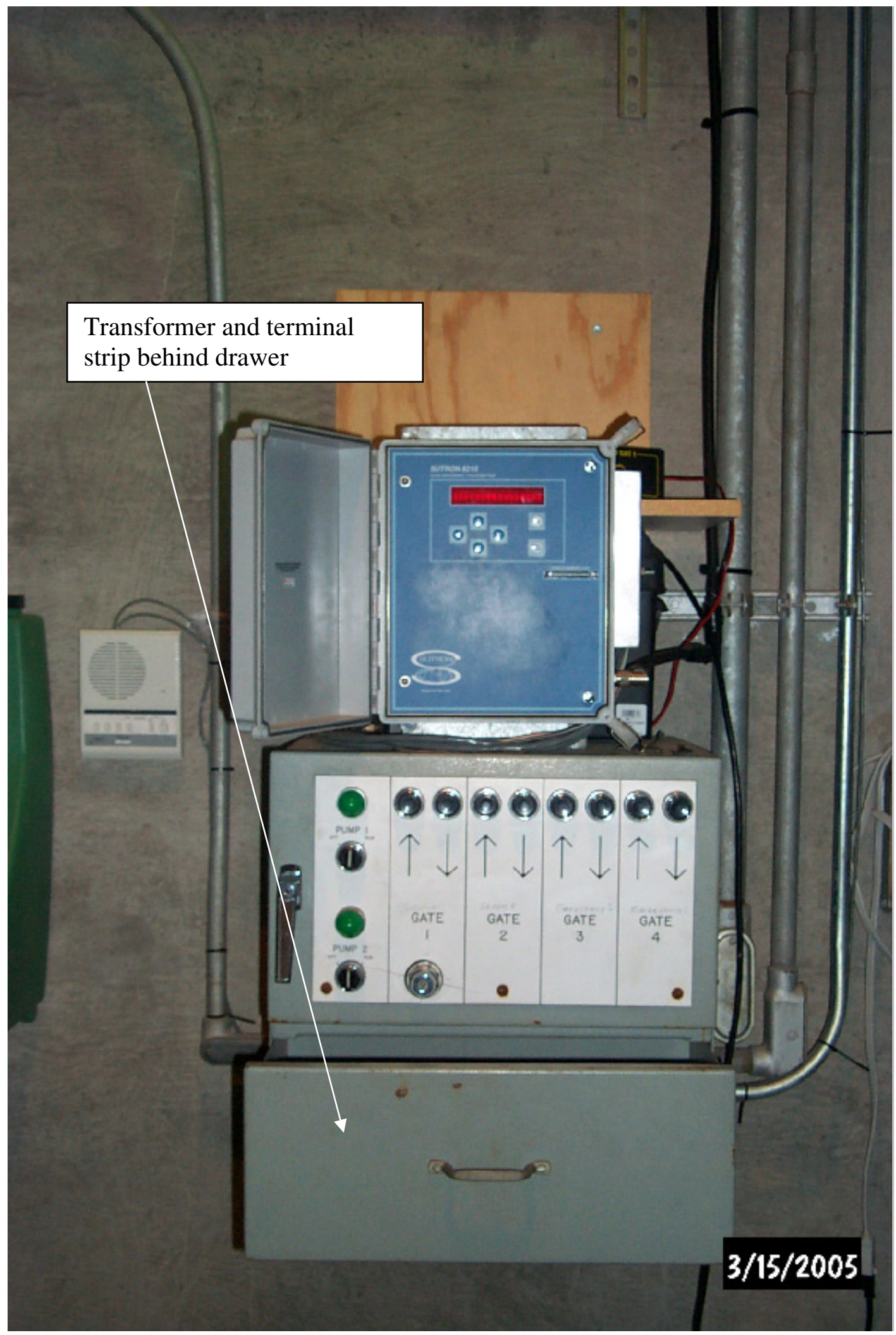

Figure 66. Sutron 8210 datalogger and gate controls at Stillhouse Hollow Lake. 


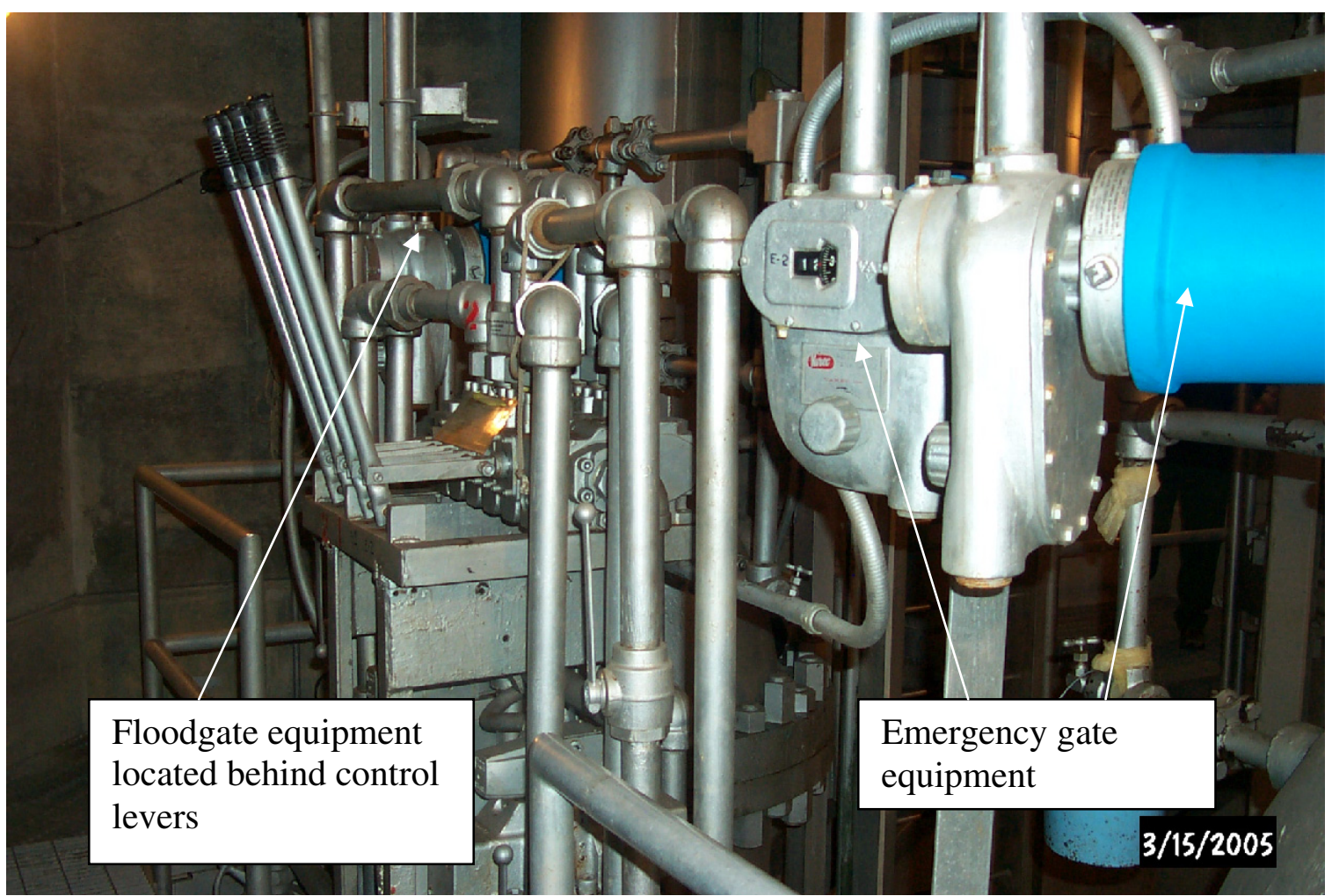

Figure 67. Manual control levers and equipment at Stillhouse Hollow Lake. 


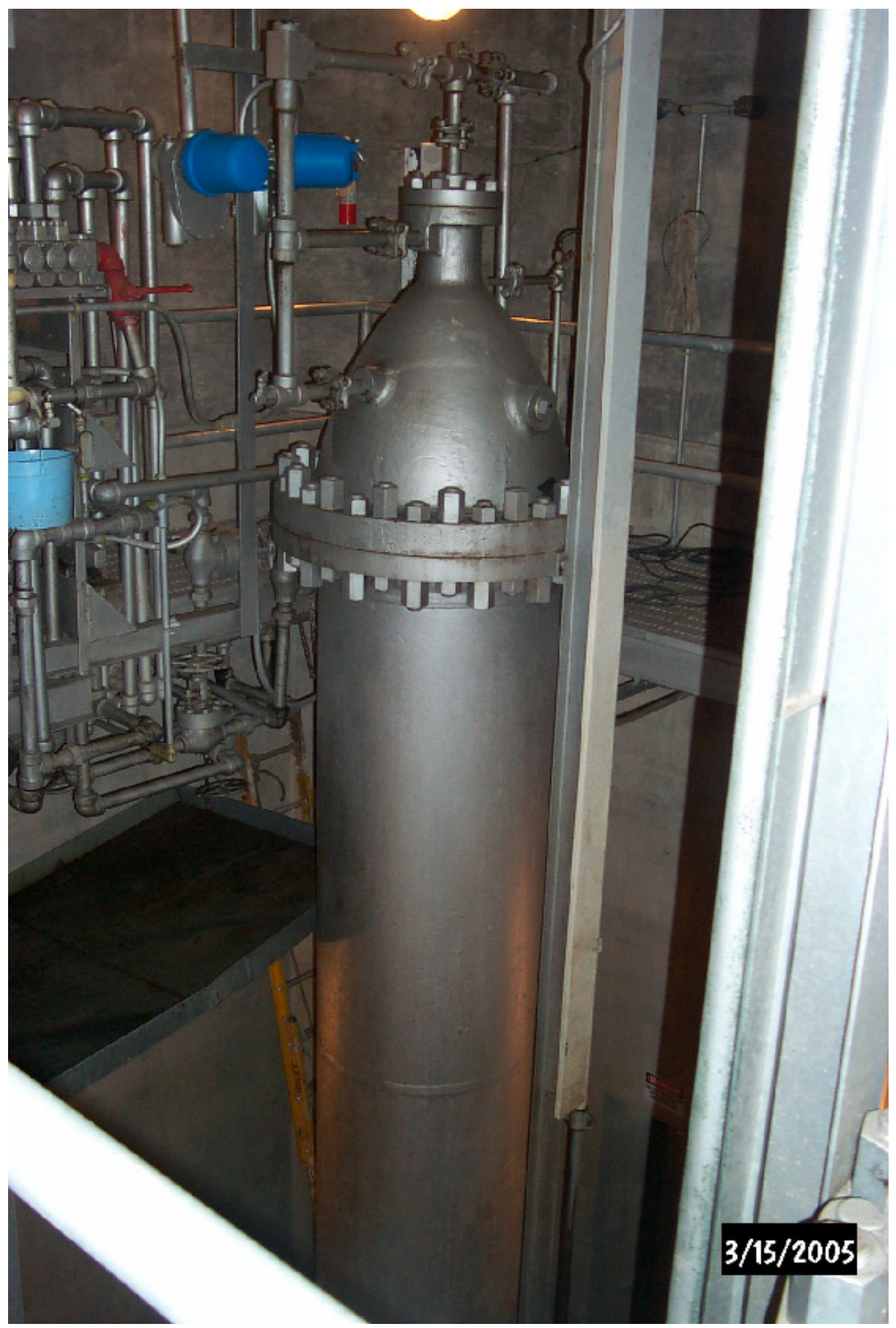

Figure 68. Hydraulic cylinder for Floodgate No. 1 at Stillhouse Hollow Lake. 


\section{Stillhouse Hollow Lake Sutron 8210 Setup File (STIT2.SET)}

; 8210/8200 ASCII setup file, can be converted back to a .SET file with WSETMGR.EXE

;

; MAIN SETUP

;

Setup_Version $=\mathrm{V} 4 \mathrm{X}$

Unit_ID=STIT2

Measurement_Interval=00:15:00

Sampling_Interval=00:00:00

Measurement_Time $=00: 00: 00$

Sampling_Time $=00: 00: 00$

Switched_Power_Time $=00: 00: 00$

Samples_to_Average $=10$

Measurements_per_Log $=1$

Switched_Power_Mode $=$ ON

Recording $=\mathrm{ON}$

Basic_Run_Interval=00:00:00

Basic_Run_Time $=00: 00: 00$

Password=

Number_Resets $=45$

Log_Size $=124928$

Rom_Checksum=31997

;

; EEROM SETUP

Serial_Port_Mode=USER

User_Baud_Rate $=9600$

Radio_Baud_Rate $=1200$

Com_Baud_Rate $=9600$

Transfer_Baud_Rate $=9600$

SDI_Baud_Rate $=1200$

Enter_Key_Reqd=ON

Log_Dump_Mode=ALL-BIN

User_Time_Limit $=660$

Power_Delay $=1$

Analog_Delay $=5$

Pressure_Delay $=5$

Auto_Startup_Keys=DDDDDDRR

Time_Format=NORMAL

Date_Format=MDY

Term_Xmit_Delay $=0$

Basic_Size $=1$

Amp_Gain=1.0

;

; PROTOCOL SETUP

Master_Name=

Carrier_Delay $=7$

Com_Port_Mode=

Reply_Delay $=0$

Ack_Delay $=100$ 


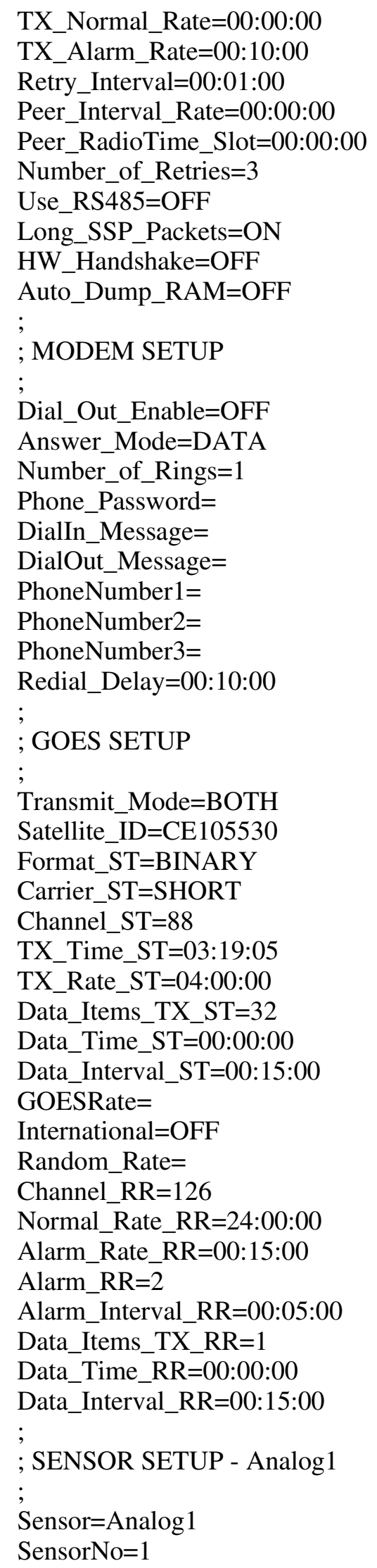




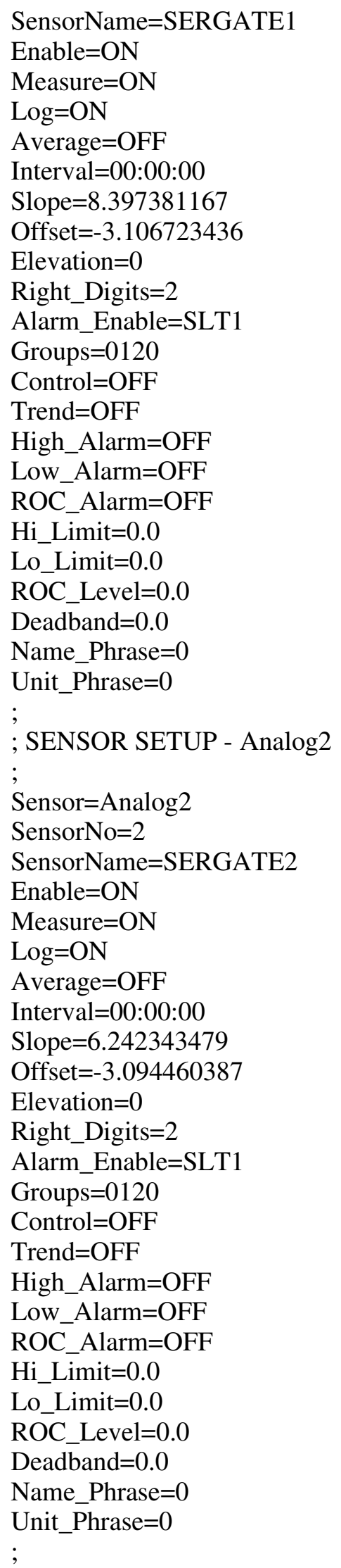




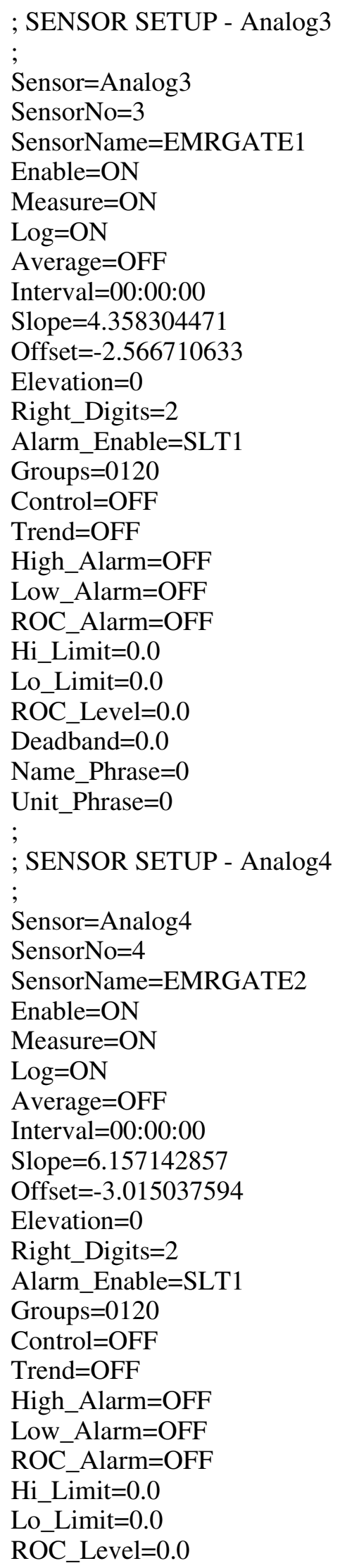




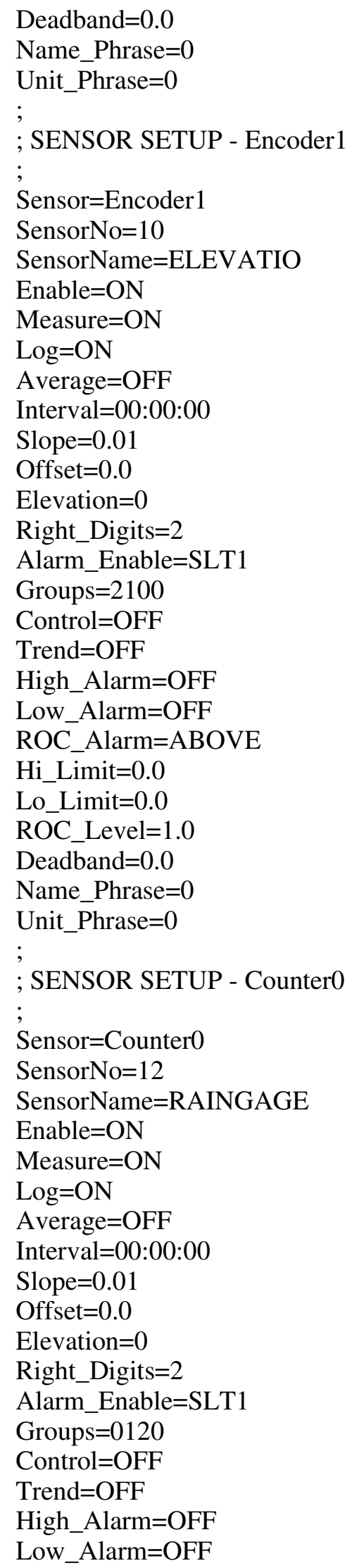


ROC_Alarm $=$ ABOVE

Hi_Limit $=0.0$

Lo_Limit $=0.0$

ROC_Level $=0.1$

Deadband $=0.0$

Name_Phrase $=0$

Unit_Phrase $=0$

;

; SENSOR SETUP - Battery

Sensor=Battery

SensorNo=34

SensorName $=$ BATTERY

Enable $=\mathrm{ON}$

Measure $=\mathrm{ON}$

$\mathrm{Log}=\mathrm{OFF}$

Average $=\mathrm{OFF}$

Interval=00:00:00

Slope $=1.0$

Offset $=0.0$

Elevation $=0$

Right_Digits=2

Alarm_Enable $=\mathrm{OFF}$

Groups $=0000$

Control $=$

Trend $=\mathrm{OFF}$

High_Alarm=OFF

Low_Alarm $=\mathrm{OFF}$

ROC_Alarm $=$ OFF

Hi_Limit $=0.0$

Lo_Limit $=0.0$

ROC_Level $=0.0$

Deadband $=0.0$

Name_Phrase $=0$

Unit_Phrase $=0$ 


\section{Wright Patman Lake Near Texarkana, Tex.}

\section{Location}

Lat $33^{\circ} 18^{\prime} 16^{\prime \prime}$, long $94^{\circ} 09^{\prime} 38^{\prime \prime}$, Bowie County, in intake structure of Wright Patman Dam on the Sulphur River, 0.5 mi upstream from US 59, 10.0 mi southwest of Texarkana, and 44.5 mi upstream from mouth.

\section{Road Log}

From USGS Texas WSC-Fort Worth, take I-20 east to I-635. Travel north on I-635 to I-30. Follow I-30 east to US 59, approximately $260 \mathrm{mi}$. Travel south on US 59 to FM 2148, approximately 10 mi. Turn right onto FM 2148 to Wright Patman Lake entrance. Turn left off FM 2148 and travel about 3 mi to intake structure and the USACE office.

\section{Access}

Before visiting the site, call the Wright Patman Dam USACE office at 903-838-8781 to let them know you will be servicing the site. USACE staff will provide access to the intake structure. The door to the intake structure has an alarm.

\section{Equipment Description}

Refer to table 14, "Wright Patman Lake equipment inventory," for a complete list of equipment and to figures 69-72 for equipment wiring diagrams and photographs of equipment. Four main gates (Floodgates No. 1, No. 2, No. 3, and No. 4) are raised and lowered by electric motors and cables. Floodgates No. 1 and No. 2 are on the right side of the intake structure (facing upstream), and Floodgates No. 3 and No. 4 are on the left.

Each gate has a Celesco VLS9600 series cable-extension transducer and a Schmitz Engineering 24MT series position transmitter, or shaft encoder, that measures the position of the gates. As a gate moves up and down, a stainless steel cable attached to the top of the gate is wound and unwound around a precisely machined constant-diameter cylindrical spool. The cable is wrapped around the cylinder with a traversing cable guide to create a single layer of wire, thereby preventing inaccuracies associated with a changing spool diameter. The spool is attached to a shaft coupled with a shaft encoder that measures the amount of linear displacement. The VLS9600 cable-extension position transducer is actually a PT9600 instrument with a VLS (velocity limiting system) attached as an option. The VLS limits cable retraction rates to a safe speed to prevent damage caused by accidental free release. The amount of cable on the spool is 1,500 in., or $125 \mathrm{ft}$.

The positions of the four floodgates are displayed on Vorne digital displays on the downstream wall of the intake structure. On the displays Floodgates No. 1, No. 2, No. 3 , and No. 4 are SG1, SG2, SG3, and SG4, respectively. For all gates, dials to indicate gate position are located on the spools on which the cables are wound and unwound to raise and lower the gates. Sometimes the dials do not function properly. They can malfunction (read incorrectly) because the dials turn as the spools turn and not necessarily when the 
gates are moving. The gates do not begin to move until all slack is out of the cables; however, the dials move as slack is taken out of the cables. Be careful using the dials as reference for the floodgates. The Celesco units and the Schmitz shaft encoders are assumed to measure the true position of the gates because the wires attached to the top of the gates do not move until the gates themselves move.

The Sutron $8200 \mathrm{~A}$ datalogger is powered by a 12 -VDC battery, which is charged by an automatic sealed lead-acid battery charger connected to a 120-VAC wall outlet. The position transmitters are powered by the Sutron 8200A datalogger. The digital displays are powered by $120 \mathrm{VAC}$.

The setup file (TXKT2.SET) and a basic program file (TXKT2.BAS) for the datalogger are stored on the RAM card that is kept adjacent to the datalogger. The basic program enables transmission of gate positions from the Sutron datalogger to the Vorne digital displays. A hard copy of the setup file and the basic program file also is kept in the station folder.

The positions of the four floodgates are transmitted by satellite and posted on the USACE Web site (http://www.swf-wc.usace.army.mil) under Daily Reports/Gate Sensor Report. The USACE reports hourly data; however, the Sutron datalogger measures and records the gate position for the gates every 15 minutes.

Floodgates No. 1, No. 2, No. 3, and No. 4 are SG1, SG2, SG3, and SG4, respectively, in the Sutron datalogger setup file and basic program file.

\section{Operation and Maintenance}

Operation and maintenance information for the equipment at Wright Patman Dam includes descriptions of different procedures required to maintain equipment such as routine inspections, recalibration of floodgates, and annual inspections. The purpose of a site visit and the actions taken should be documented in the logbook kept near the datalogger. Include the date, time, actions, and personnel conducting the site visit in the logbook. This section lists some of the potential problems that might occur with the equipment in service and possible solutions to the problems. Refer to the Operations Manuals for the individual pieces of equipment when further detail is required. The information included here is basic operations and maintenance information.

For each visit to the site, personnel should carry all of the necessary tools required to service the equipment. The tools required to perform all of the tasks listed include the following:

- Screwdrivers, flat and Phillips head

- Allen wrenches, 5/32- and 7/64-in.

- Crescent wrench, 10-in.

- Stepladder, 10-ft

- Electrical tape

- Digital multimeter

- Pliers

- Ruler

- Laptop computer capable of connecting (with RS-232 port and 9-pin cable) to Sutron 8200A

- Sutron 8200A Operations Manual

- Battery load tester 
- Spare battery

- Flashlight

- Silicone sealant

\section{Procedures during a Routine Inspection}

- Check the enclosure to the Sutron 8210 datalogger for damage and moisture. If moisture is entering the enclosure, seal any openings with silicone.

- Scroll through the VIEW DATA/LIVE READINGS menu and check that the datalogger is making measurements.

- Check the antenna and make sure connections are secure and waterproofed. Replace electrical tape around connections if old and brittle.

- Check the battery voltage under the LIVE READINGS menu on the Sutron 8200A.

- If voltage is low (less than $11.5 \mathrm{~V}$ ), test the battery with a load tester and make sure the voltage remains above the recommended voltage specific to the load tester being used. Replace battery as needed.

- Check the Vorne digital displays and make sure that the displays are reporting the same gate positions as the Sutron 8200A and that display digits are illuminated. Note that the digital displays only report the gate positions to two significant figures $(0.0)$ and that the Sutron reports the positions to three $(0.00)$.

- Verify Floodgates No. 1, No. 2, No. 3, and No. 4 position sensors and transmitters are functioning properly by pulling down on the Celesco steel wire a known distance and checking the reading on the display. Hold a ruler flush with the bottom of the Celesco unit. Pull the wire down $1 \mathrm{ft}$ and verify that the Vorne display reads $1 \mathrm{ft}$ less than the current reading. If the actual amount of displacement and the measured amount do not agree, make a note of the difference. Make sure the difference is not caused by inaccuracies associated with trying to pull the wire down a known distance. According to the manufacturer, at $1 \mathrm{ft}$ of displacement the unit is accurate to within $0.0004 \mathrm{ft}$. Do not try to force agreement between the displaced amount and the measured amount by adjusting the slope or the offset in the Sutron 8200A setup. However, check that the slope is set properly to 1.0511 for both shaft encoders and adjust if set incorrectly (see "Procedures to recalibrate Floodgates No. 1, No. 2, No. 3, and No. 4"). Check that the connections between the shaft encoders and the Celesco position sensors are good by making sure the Allen screws that connect the two are not loose. Open the cover on the position sensor where the wire enters the unit. Visually check that the wire appears to be winding up uniformly across the wheel and that no kinks are present. Do not try to remove the cylinder that holds the wire. If the wire is pulled down and the shaft encoder does not respond at all (no change in position), check that the SDI12 addresses are set correctly in the Sutron 8200A setup. Floodgates No. 1, No. 2, No. 3, and No. 4 should have addresses 1, 2, 3, and 4, respectively. If the slopes are set correctly, the connections and wire appear good, the shaft encoders are responding, and the SDI12 addresses are set correctly, then the shaft encoders or the Celesco position sensors need to be replaced or serviced. Try removing the shaft encoder first and testing it with another Celesco unit known to function properly to try to isolate the problem. If the shaft encoder is good, the Celesco unit should probably 
be removed and serviced. This will have to be done during an annual inspection. Refer to the "Manufacturer Contact Information" section for address and phone number.

- Whenever a change is made to the setup file or the basic program in the datalogger, download the new files to the RAM card kept at the site. To do this, insert the RAM card into the socket and turn on the 8200A. Scroll down to the DUMP DATA menu. Press the right arrow once, then press the down arrow until WRITE CARD SETUP is displayed. Press the SET button and wait for the files to be transferred from the datalogger to the RAM card. Note that when doing this, both the setup file and the basic program get transferred to the RAM card. To transfer the files from the RAM card to the datalogger, scroll down to the DUMP DATA menu. Press the right arrow once, then press the down arrow until READ CARD SETUP is displayed. Press the right arrow to access the setup file and the basic program. Press the down arrow to select which file to transfer to the datalogger. Transfer the selected file to the datalogger by pressing the SET button. Transfer both the setup file and the basic program.

- Before leaving the site, make sure the Sutron 8200A is reading ON \& TX under RECORDING.

\section{Procedures to recalibrate Flood Gates No. 1, No. 2, No. 3, and No. 4}

- First make sure that the slope of the shaft encoders is set to 1.0511 , as one revolution of the Celesco is 12.613 in. With the gates closed, set the instruments to read zero by adjusting the offset of the Schmitz Engineering shaft encoders.

- To change the offset or the slope, turn on the Sutron 8200A and press the down arrow to SYSTEM SETUP. Press the right arrow once and the down arrow twice to CONFIG SENSORS. Then press the right arrow once and the down arrow to select the floodgate. With the correct shaft encoder selected, press the right arrow once and then the down arrow to slope and offset. Press the SET button once when either slope or offset are highlighted. Change the value using the arrow buttons. Right and left arrow buttons move from one digit to the next. Up and down arrow buttons increase or decrease the value, respectively. When finished, press the SET button to save the new value. Check LIVE READINGS or the digital display to see the new measured value.

- Record changes to the slope or the offset in the logbook and save the new setup file to the RAM card.

\section{Procedures during an Annual Inspection}

- During an inspection the emergency bulkheads are lowered, and the floodgates are raised all the way up into the intake structure where they are cleaned and inspected. As the gates are raised, check and clean the wire as it winds up into the Celesco position sensor. Check the wire for worn areas and clean debris off the wire. If the wire appears substantially damaged do not try to replace the wire. Send the unit to Celesco for service. Refer to the "Manufacturer Contact Information" section for address and phone number. 
- When the gates are lowered and closed after being serviced, check that the shaft encoders and datalogger measure zero. If not, follow the instructions on how to recalibrate the instruments.

- After the inspection, follow all of the procedures during a routine inspection. 
Table 14. Wright Patman Lake equipment inventory.

[See table of contents for abbreviated units; --, not available or not applicable]

\begin{tabular}{|c|c|c|c|c|}
\hline $\begin{array}{c}\text { Item } \\
\text { no. }\end{array}$ & Item description & Manufacturer & Model no. & Remarks \\
\hline 1. & Floodgate No. 1 position sensor & Celesco & VLS9600-1500-114-SCH-24MTF & $\begin{array}{l}\text { Gate is SG1 in Sutron setup and } \\
\text { equipment is labeled Hoist Controller } 1\end{array}$ \\
\hline 2. & Floodgate No. 1 position transmitter & Schmitz Engineering & 24MT-256-4096-SDI12-CR6-375/879-SUT & Shaft encoder with SDI12 address 1 \\
\hline 3. & Wire for position transmitter No. 1 & -- & -- & $\begin{array}{l}110 \mathrm{ft} \text { of } 16 \mathrm{AWG} / 3 \text { wires going from } \\
\text { transmitter to terminal strip A and then to } \\
\text { Sutron } 8200 \mathrm{~A}\end{array}$ \\
\hline 4. & Floodgate No. 2 position sensor & Celesco & VLS9600-1500-114-SCH-24MTF & $\begin{array}{l}\text { Gate is SG2 in Sutron setup and } \\
\text { equipment is labeled Hoist Controller } 2\end{array}$ \\
\hline 5. & Floodgate No. 2 position transmitter & Schmitz Engineering & 24MT-256-4096-SDI12-CR6-375/879-SUT & Shaft encoder with SDI12 address 2 \\
\hline 6. & Wire for position transmitter No. 2 & -- & -- & $\begin{array}{l}110 \mathrm{ft} \text { of } 16 \mathrm{AWG} / 3 \text { wires going from } \\
\text { transmitter to terminal strip A and then to } \\
\text { Sutron } 8200 \mathrm{~A}\end{array}$ \\
\hline 7. & Floodgate No. 3 position sensor & Celesco & VLS9600-1500-114-SCH-24MTF & $\begin{array}{l}\text { Gate is SG3 in Sutron setup and } \\
\text { equipment is labeled Hoist Controller } 3\end{array}$ \\
\hline 8. & Floodgate No. 3 position transmitter & Schmitz Engineering & 24MT-256-4096-SDI12-CR6-375/879-SUT & Shaft encoder with SDI12 address 3 \\
\hline 9. & Wire for position transmitter No. 3 & -- & -- & $\begin{array}{l}145 \mathrm{ft} \text { of } 16 \mathrm{AWG} / 3 \text { wires going from } \\
\text { transmitter to terminal strip A and then to } \\
\text { Sutron } 8200 \mathrm{~A}\end{array}$ \\
\hline 10. & Floodgate No. 4 position sensor & Celesco & VLS9600-1500-114-SCH-24MTF & $\begin{array}{l}\text { Gate is SG4 in Sutron setup and } \\
\text { equipment is labeled Hoist Controller } 4\end{array}$ \\
\hline 11. & Floodgate No. 4 position transmitter & Schmitz Engineering & 24MT-256-4096-SDI12-CR6-375/879-SUT & Shaft encoder with SDI12 address 4 \\
\hline 12. & Wire for position transmitter No. 4 & -- & -- & $\begin{array}{l}110 \mathrm{ft} \text { of } 16 \mathrm{AWG} / 3 \text { wires going from } \\
\text { transmitter to terminal strip A and then to } \\
\text { Sutron } 8200 \mathrm{~A}\end{array}$ \\
\hline 13. & Stage shaft encoder & Handar & $436 \mathrm{~A}$ & Named SE_STAGE in Sutron setup \\
\hline 14. & Rain gage & -- & -- & Instrument not labeled \\
\hline 15. & Datalogger & Sutron & $8200 \mathrm{~A}$ & -- \\
\hline 16. & $\begin{array}{l}\text { Digital displays for Floodgates } \\
\text { No. } 1 \text {, No. } 2 \text {, No. } 3 \text {, and No. } 4\end{array}$ & Vorne Industries & GY2200 & $\begin{array}{l}\text { Connected to Sutron 8200A through } \\
\text { RS-232 9-pin cable and powered by } \\
120 \text {-VAC wall outlet }\end{array}$ \\
\hline 17. & Battery & Douglas & Guardian DG 12-80 & 12-V, 80-A-h battery for Sutron 8200A \\
\hline 18. & Battery charger & Power Sonic & PSC-12800A & $12-\mathrm{V}, 800-\mathrm{mA}$ \\
\hline 19. & Antenna & -- & YAGI & $\begin{array}{l}\text { Mounted on upstream side of intake } \\
\text { structure }\end{array}$ \\
\hline 20. & Antenna cable & Alpha Wire-J & PN 9008 RG 8/U & 40-ft cable from Sutron 8200A to antenna \\
\hline 21. & Antenna polyphaser & Polyphaser & IS-50NX-C1 & -- \\
\hline
\end{tabular}




\section{Job Hazard Analysis}

Required protective clothing, safety equipment, and supplies: Personal flotation device (PFD), reflective vest, gloves, steel-toed shoes, waders, cell phone, first aid kit, fire extinguisher, rotating or strobe type emergency lights, drinking water.

\begin{tabular}{|c|c|c|}
\hline $\begin{array}{l}\text { Sequence of basic } \\
\text { job steps }\end{array}$ & $\begin{array}{l}\text { Potential } \\
\text { accident or hazard }\end{array}$ & Recommended safe job procedures \\
\hline $\begin{array}{l}\text { Upon job } \\
\text { assignment }\end{array}$ & $\begin{array}{l}\text { Water-related accident or } \\
\text { injury }\end{array}$ & $\begin{array}{l}\text { Employees working in and around water must receive } \\
\text { training specified in WRD Memo 2000.10, "Policy for } \\
\text { safety training associated with over-water activities." }\end{array}$ \\
\hline $\begin{array}{l}\text { Loading and } \\
\text { unloading } \\
\text { equipment }\end{array}$ & $\begin{array}{l}\text { Pinched fingers, mashed } \\
\text { toes, or strained back }\end{array}$ & $\begin{array}{l}\text { Be aware of hand placement. Wear protective gloves and } \\
\text { steel-toed shoes. Use proper lifting techniques. Lift with } \\
\text { legs. Use extra caution lifting heavy sounding weights. }\end{array}$ \\
\hline $\begin{array}{l}\text { Driving to and } \\
\text { returning from work } \\
\text { site }\end{array}$ & $\begin{array}{l}\text { Traffic accidents, vehicle } \\
\text { flooding, or drowning }\end{array}$ & $\begin{array}{l}\text { Drivers of USGS vehicles must have Drivers Safety } \\
\text { Training (SM 445-2-H, chap. 16). Be alert to traffic in } \\
\text { area, obey all traffic laws, and reduce speed when weather } \\
\text { conditions are bad. Do not drive across flooded highways } \\
\text { unless water depth and bridge conditions are known to be } \\
\text { safe. }\end{array}$ \\
\hline Parking vehicle & $\begin{array}{l}\text { Personal and vehicle } \\
\text { safety when exiting } \\
\text { vehicle in traffic; bank } \\
\text { collapse or bridge failure }\end{array}$ & $\begin{array}{l}\text { Use rotating or strobe emergency lights, follow site } \\
\text { traffic-control plan, wear DOT Type III reflective vest } \\
\text { when working in or near roadway. Park away from stream } \\
\text { at a safe distance from banks. }\end{array}$ \\
\hline $\begin{array}{l}\text { Set up traffic- } \\
\text { control equipment }\end{array}$ & $\begin{array}{l}\text { Personal and public } \\
\text { safety }\end{array}$ & $\begin{array}{l}\text { Employees working in or near roadways must have Work } \\
\text { Zone Traffic-Control Safety Training. Remain alert to } \\
\text { traffic conditions. }\end{array}$ \\
\hline $\begin{array}{l}\text { Working at field } \\
\text { site }\end{array}$ & Drowning & $\begin{array}{l}\text { Employees are required to wear a PFD when working in, } \\
\text { on, or over any body of water. There are no exemptions } \\
\text { for employees in the Texas WSC. PFDs will be } \\
\text { international orange in color and equipped with reflective } \\
\text { tape in accordance with } 46 \text { CFR } 25.25-15 \text {. Self-inflating } \\
\text { PFDs are not to be worn by employees who have not had } \\
\text { In-Water Safety Training. }\end{array}$ \\
\hline $\begin{array}{l}\text { Working at field } \\
\text { site }\end{array}$ & Trips, slips, and falls & $\begin{array}{l}\text { Follow path clear of obstructions and with minimal slope; } \\
\text { avoid slippery surfaces. Walk cautiously on steep slopes } \\
\text { or paths with loose material. Use appropriate footwear for } \\
\text { the terrain and conditions. Follow the safest, not the } \\
\text { fastest path! }\end{array}$ \\
\hline $\begin{array}{l}\text { Working at field } \\
\text { site }\end{array}$ & $\begin{array}{l}\text { Dehydration, heat } \\
\text { exhaustion, heat stroke, } \\
\text { or sunburn }\end{array}$ & $\begin{array}{l}\text { Drink plenty of water or electrolyte drink. Wear } \\
\text { appropriate clothing. Take occasional breaks and watch } \\
\text { for symptoms of heat exhaustion. Use sun block. }\end{array}$ \\
\hline $\begin{array}{l}\text { Working at field } \\
\text { site }\end{array}$ & Hypothermia or frostbite & $\begin{array}{l}\text { Wear foul-weather gear during winter months. Keep } \\
\text { clothing dry. }\end{array}$ \\
\hline $\begin{array}{l}\text { Working at field } \\
\text { site }\end{array}$ & Snake bites & $\begin{array}{l}\text { Wear appropriate foot and leg protection. Watch path } \\
\text { ahead. Keep area around gage clear of brush. If bitten, } \\
\text { seek immediate medical help. }\end{array}$ \\
\hline
\end{tabular}




\begin{tabular}{|l|l|l|}
\hline $\begin{array}{l}\text { Working at field } \\
\text { site }\end{array}$ & Poisonous plants & $\begin{array}{l}\text { Know how to identify poisonous plants. Wear protective } \\
\text { clothing. Wash and flush exposed areas immediately with } \\
\text { cold water. Wash with degreasing type soap and flush } \\
\text { from skin. Seek medical attention for severe reactions. }\end{array}$ \\
\hline Entering gage house & $\begin{array}{l}\text { Infectious disease or } \\
\text { airborne pollutants; risk } \\
\text { of hantavirus exposure }\end{array}$ & $\begin{array}{l}\text { Watch for bats or rodent nests and droppings. If nest or } \\
\text { droppings are present, do not disturb dust. Gage should be } \\
\text { periodically cleaned to minimize risk of exposure. See } \\
\text { WRD memo dated 10/28/97, "Preventing hantavirus } \\
\text { disease," and OP memo dated 01/94, "Instructions for } \\
\text { preventing hantavirus disease." }\end{array}$ \\
\hline Entering gage house & Insect or snake bites & $\begin{array}{l}\text { Inspect in and around shelter for harmful insects. Use } \\
\text { wasp or insect spray. Inspect in and around shelter for } \\
\text { snakes prior to entry. }\end{array}$ \\
\hline
\end{tabular}

\section{Site-Specific Job Hazards}

The items listed are safety issues specific to this site that deserve special emphasis.

- Be careful removing or installing the Celesco position transmitters or the Schmitz shaft encoders on Floodgates No. 1 and No. 2. The gaps between the spools holding the cable to raise and lower the gates are a fall hazard.

- The Vorne digital displays are about $12 \mathrm{ft}$ off the floor of the intake structure and therefore require a stepladder when being checked or changed out. 


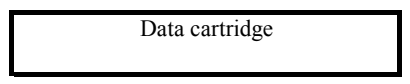

RS-232 To digital displays
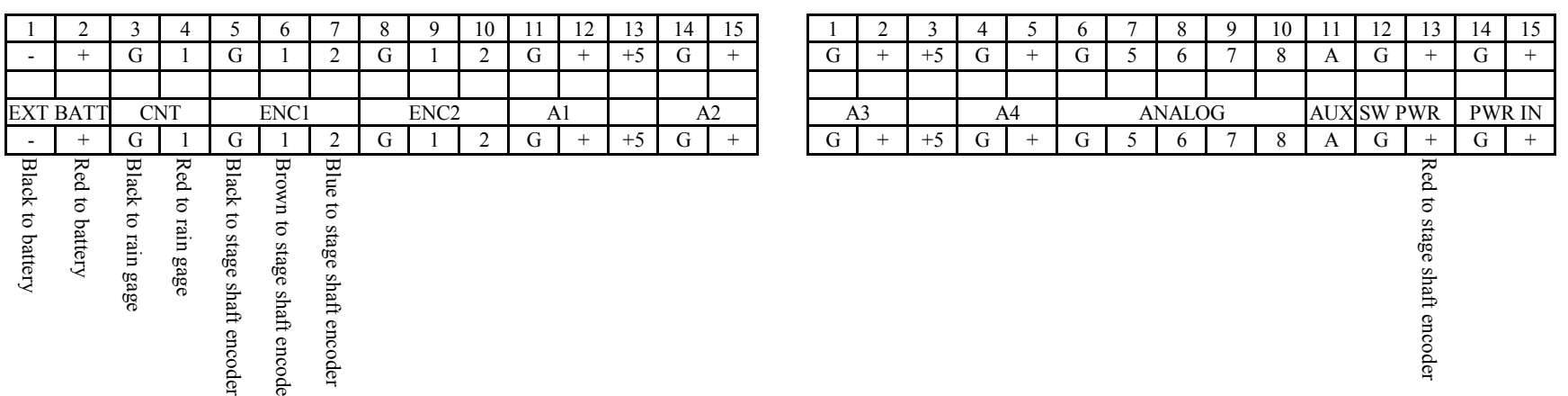

SDI-12 To terminal strip A (see

GND

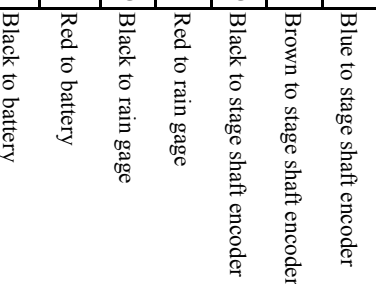

photo and diagram)

RF OUTPUT

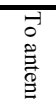


Figure 70. Wright Patman Lake equipment wiring diagram.
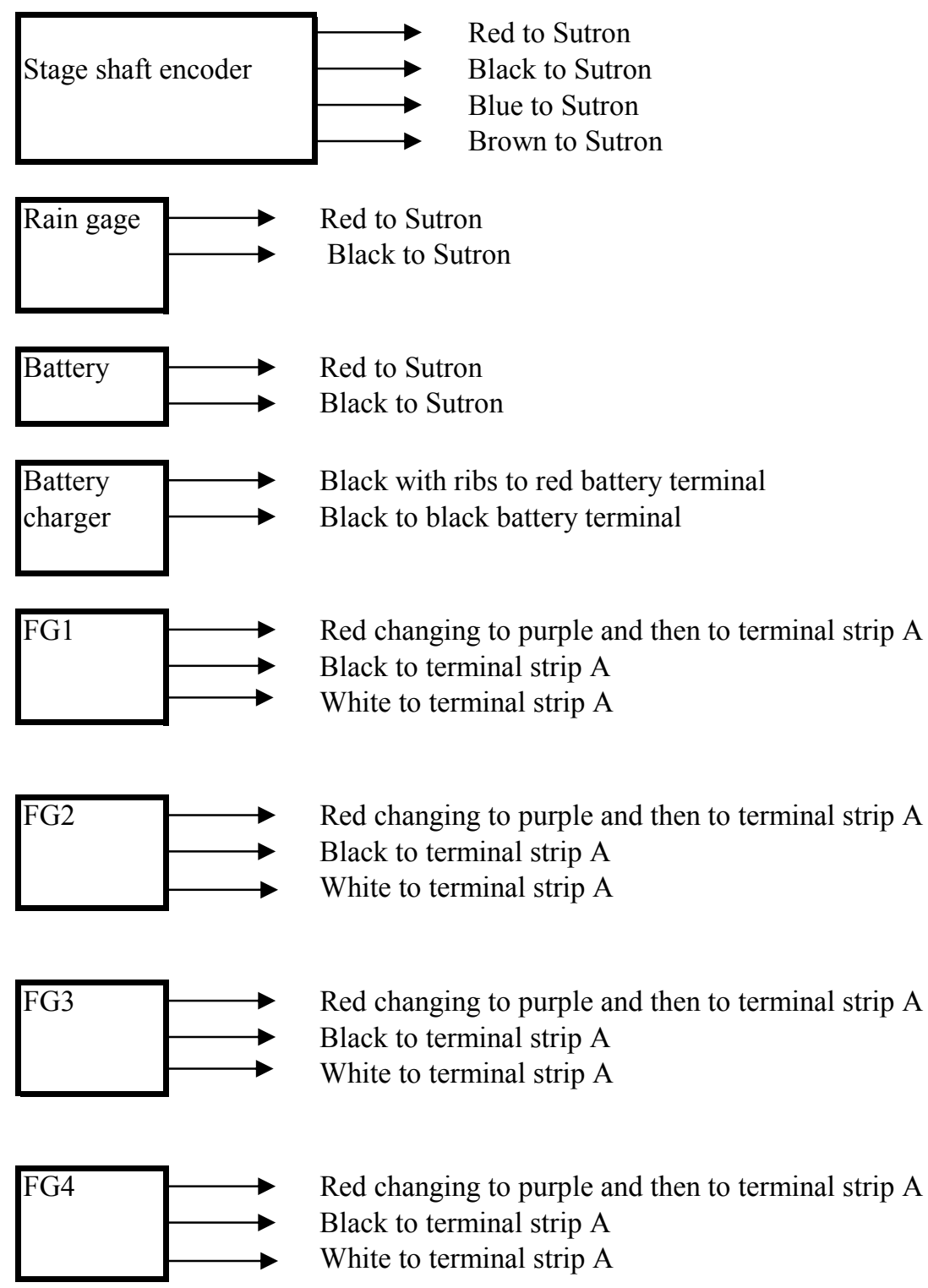

Note: $\quad$ FG1, Floodgate No. 1 or SG1 (Sutron setup.file name).

FG2, Floodgate No. 2 or SG2 (Sutron setup.file name).

FG3, Floodgate No. 3 or SG3 (Sutron setup.file name).

FG4, Floodgate No. 4 or SG4 (Sutron setup.file name). 
Figure 70. Wright Patman Lake equipment wiring diagram--Continued.

\section{Terminal strip A}

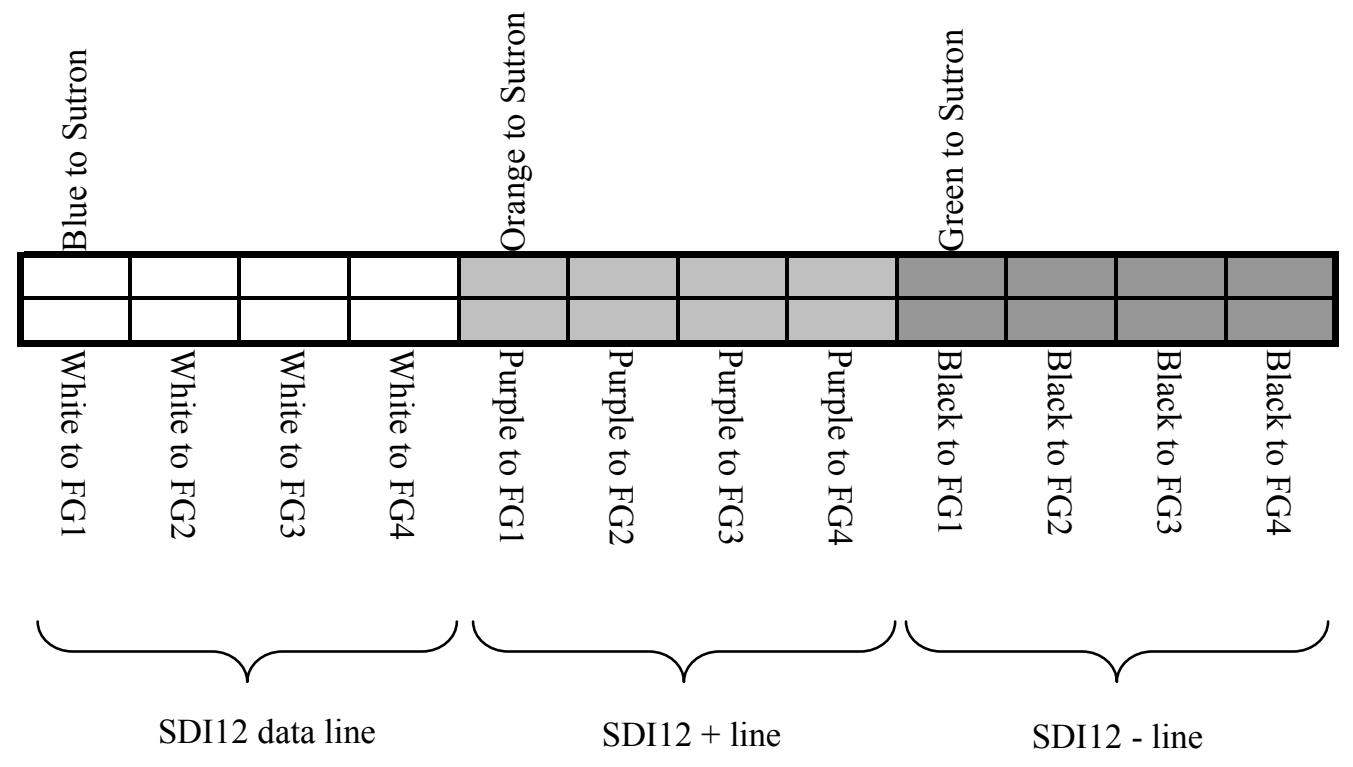

Note: FG1, Floodgate No. 1 or SG1 (Sutron setup.file name).

FG2, Floodgate No. 2 or SG2 (Sutron setup.file name).

FG3, Floodgate No. 3 or SG3 (Sutron setup.file name).

FG4, Floodgate No. 4 or SG4 (Sutron setup.file name).

Similarly shaded cells are connected with jumpers. 


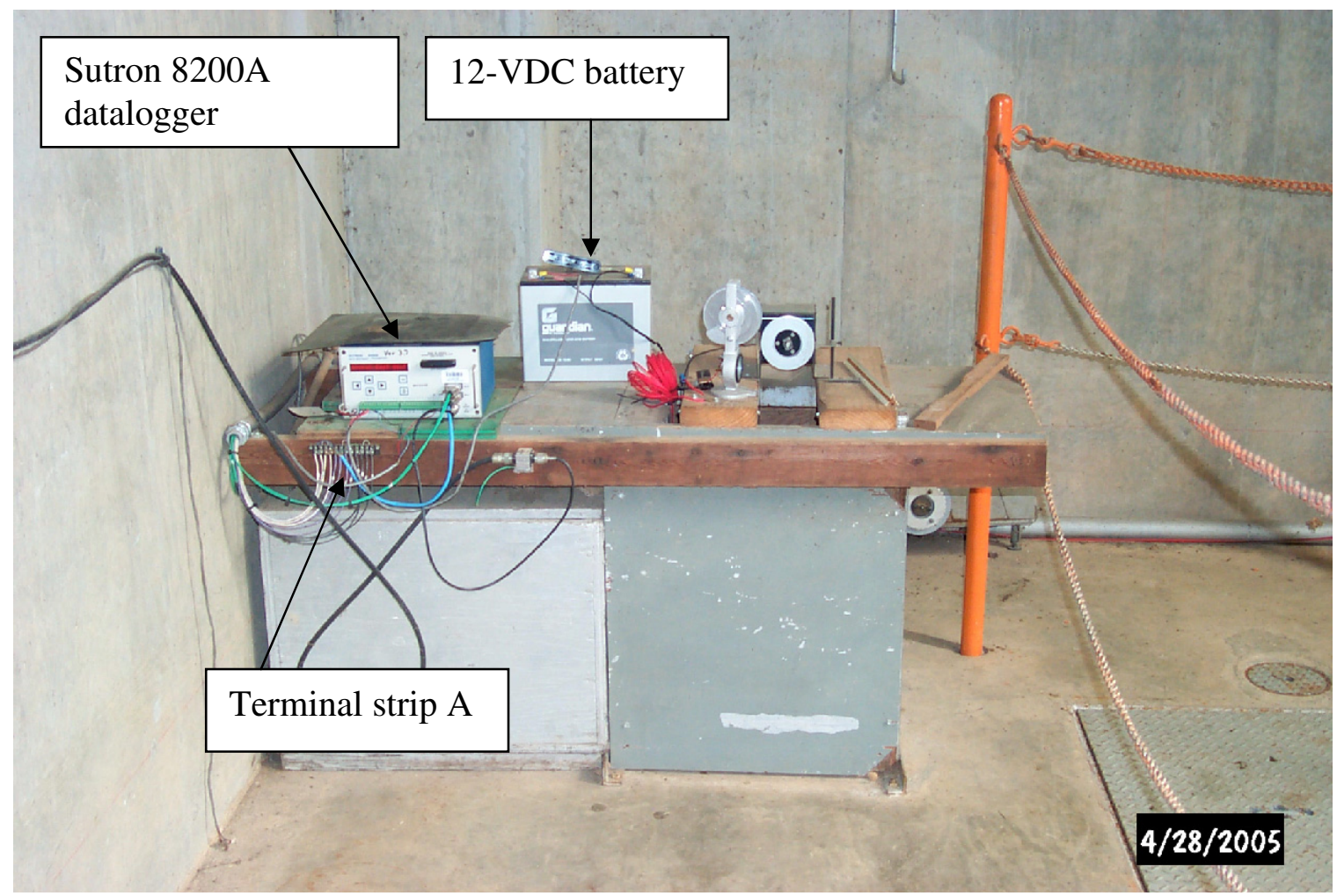

Figure 71. Sutron datalogger at Wright Patman Lake.

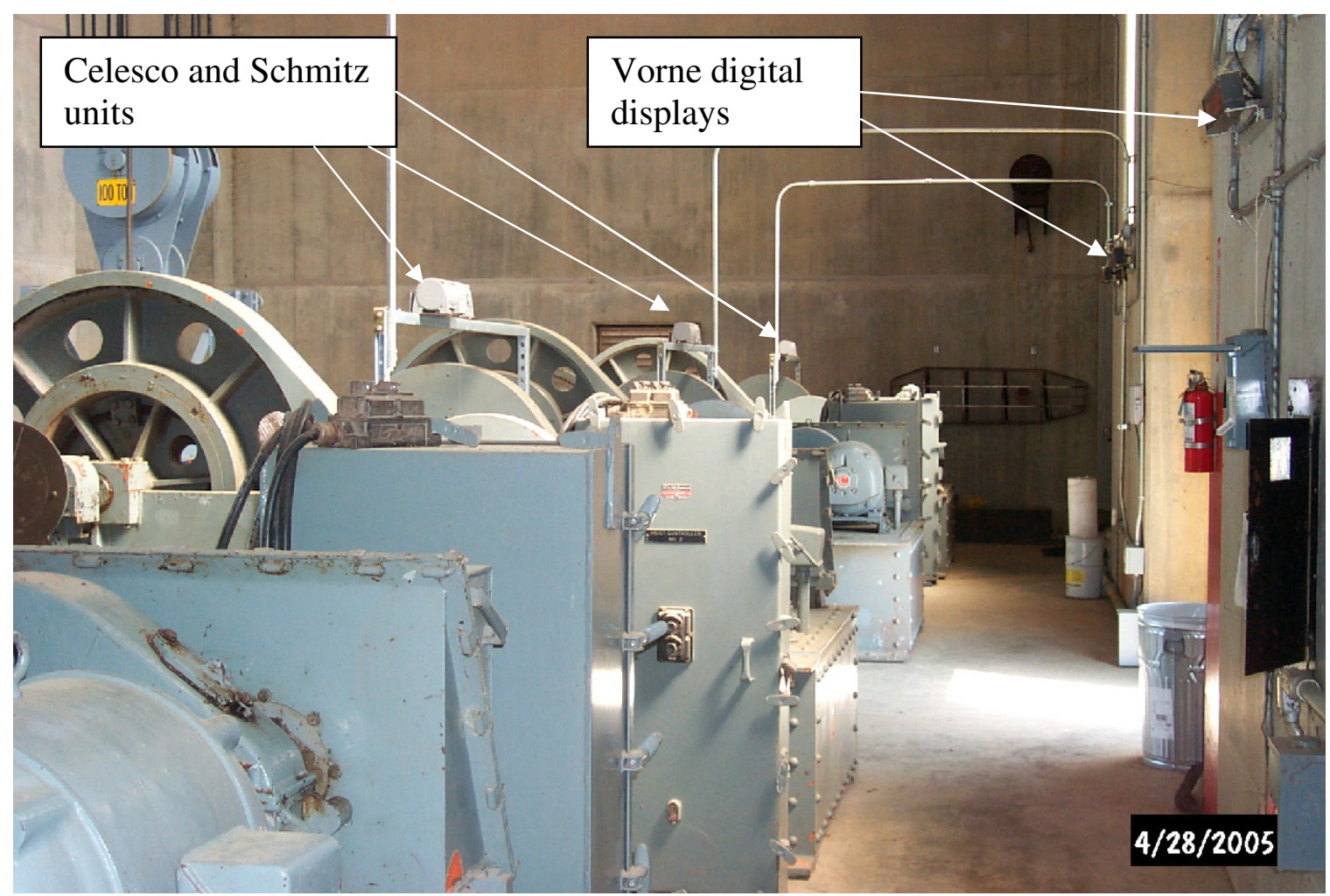

Figure 72. Gate-sensing equipment at Wright Patman Lake. 


\section{Wright Patman Lake Sutron 8200A Setup File (TXKT2.SET)}

; 8210/8200 ASCII setup file, can be converted back to a .SET file with WSETMGR.EXE

;

; MAIN SETUP

Setup_Version=G3A

Unit_ID=TXKT2

Measurement_Interval=00:15:00

Sampling_Interval $=00: 00: 00$

Measurement_Time $=00: 00: 00$

Sampling_Time $=00: 00: 00$

Switched_Power_Time $=00: 00: 00$

Samples_to_Average $=10$

Measurements_per_Log=1

Switched_Power_Mode $=\mathrm{ON}$

Recording $=\mathrm{ON}$

Basic_Run_Interval=00:00:10

Basic_Run_Time $=00: 00: 00$

Password $=$

Number_Resets $=0$

Log_Size $=126976$

Rom_Checksum $=14526$

;

; EEROM SETUP

;

Serial_Port_Mode $=$ USER

User_Baud_Rate $=9600$

Radio_Baud_Rate $=1200$

Com_Baud_Rate $=9600$

Transfer_Baud_Rate $=9600$

SDI_Baud_Rate $=1200$

Enter_Key_Reqd=OFF

Log_Dump_Mode=ALL-BIN

User_Time_Limit $=600$

Power_Delay $=1$

Analog_Delay $=5$

Pressure_Delay $=5$

Auto_Startup_Keys=SSDDDDDDRRDPPPDPPPUU

Time_Format=NORMAL

Date_Format=MDY

Term_Xmit_Delay $=0$

Basic_Size $=1$

Amp_Gain=1.0

;

; PROTOCOL SETUP

Master_Name $=$

Carrier_Delay $=7$

Com_Port_Mode=

Reply_Delay $=0$

Ack_Delay $=100$

TX_Normal_Rate $=00: 00: 00$

TX_Alarm_Rate $=00: 10: 00$ 
Retry_Interval=00:01:00

Peer_Interval_Rate $=00: 00: 00$

Peer_RadioTime_Slot $=00: 00: 00$

Number_of_Retries $=3$

Use_RS485=

Long_SSP_Packets $=\mathrm{ON}$

HW_Handshake=

Auto_Dump_RAM=

;

; MODEM SETUP

Dial_Out_Enable=

Answer_Mode=DATA

Number_of_Rings=1

Phone_Password=

DialIn_Message $=$

DialOut_Message=

PhoneNumber1=

PhoneNumber2=

PhoneNumber $3=$

Redial_Delay $=00: 10: 00$

;

; GOES SETUP

;

Transmit_Mode=TIMED

Satellite_ID=CE40CAC2

Format_ST=BINARY

Carrier_ST=LONG

Channel_ST $=88$

TX_Time_ST $=03: 02: 01$

TX_Rate_ST=04:00:00

Data_Items_TX_ST $=32$

Data_Time_ST=00:00:00

Data_Interval_ST $=00: 15: 00$

GOESRate $=$

International $=\mathrm{OFF}$

Random_Rate $=$

Channel_RR $=126$

Normal_Rate_RR=00:00:00

Alarm_Rate_RR=00:00:00

Alarm_RR $=0$

Alarm_Interval_RR $=00: 00: 00$

Data_Items_TX_RR $=0$

Data_Time_RR $=00: 00: 00$

Data_Interval_RR=00:00:00

;

; SENSOR SETUP - Encoder1

;

Sensor=Encoder 1

SensorNo $=10$

SensorName=SE_STAGE

Enable $=\mathrm{ON}$

Measure $=\mathrm{ON}$

$\mathrm{Log}=\mathrm{ON}$

Average $=\mathrm{OFF}$ 
Interval $=00: 15: 00$

Slope $=0.01$

Offset $=200.0$

Elevation $=0$

Right_Digits=2

Alarm_Enable $=$ SLT1

Groups $=0100$

Control=OFF

Trend=OFF

High_Alarm $=\mathrm{OFF}$

Low_Alarm $=\mathrm{OFF}$

ROC_Alarm $=\mathrm{OFF}$

Hi_Limit $=0.0$

Lo_Limit $=0.0$

ROC_Level $=0.0$

Deadband $=0.0$

Name_Phrase $=0$

Unit_Phrase $=0$

;

; SENSOR SETUP - Counter0

;

Sensor $=$ Counter0

SensorNo=12

SensorName $=$ RAINGAGE

Enable $=\mathrm{ON}$

Measure $=\mathrm{ON}$

$\mathrm{Log}=\mathrm{ON}$

Average $=\mathrm{OFF}$

Interval $=00: 15: 00$

Slope $=0.01$

Offset $=0.05$

Elevation $=0$

Right_Digits=2

Alarm_Enable $=$ SLT 1

Groups $=0100$

Control=OFF

Trend=OFF

High_Alarm=OFF

Low_Alarm $=\mathrm{OFF}$

ROC_Alarm $=\mathrm{OFF}$

Hi_Limit $=0.0$

Lo_Limit $=0.0$

ROC_Level $=0.0$

Deadband $=0.0$

Name_Phrase $=0$

Unit_Phrase $=0$

;

; SENSOR SETUP - Battery

;

Sensor=Battery

SensorNo=34

SensorName $=$ BATTERY

Enable $=\mathrm{ON}$

Measure $=\mathrm{ON}$

$\mathrm{Log}=\mathrm{OFF}$ 


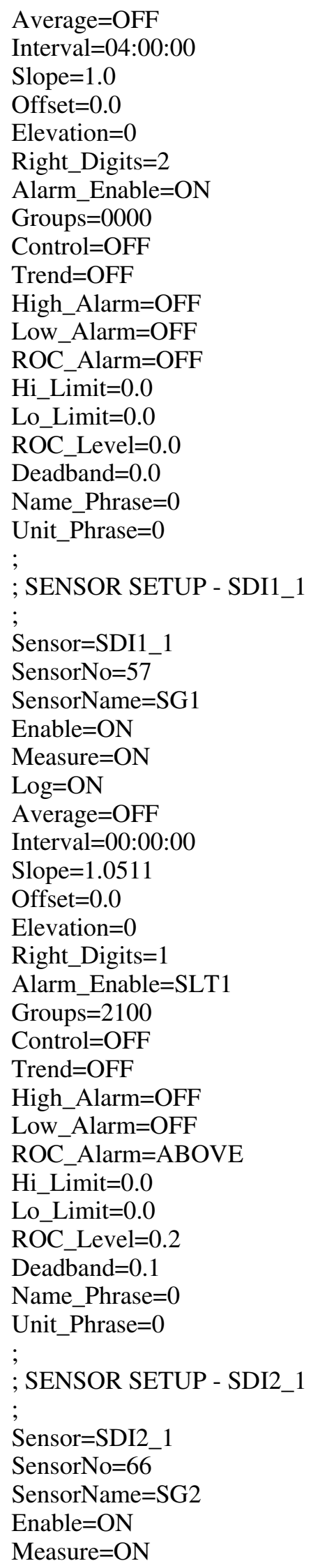




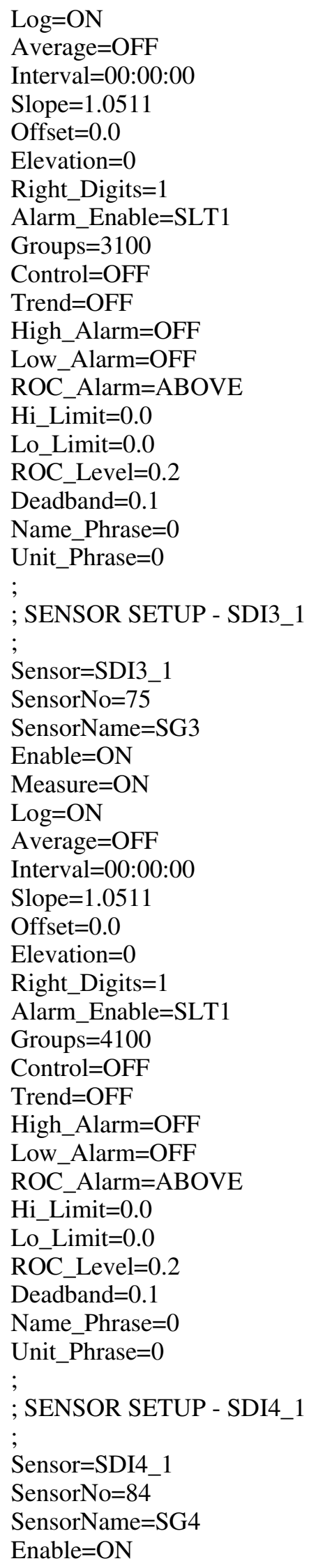




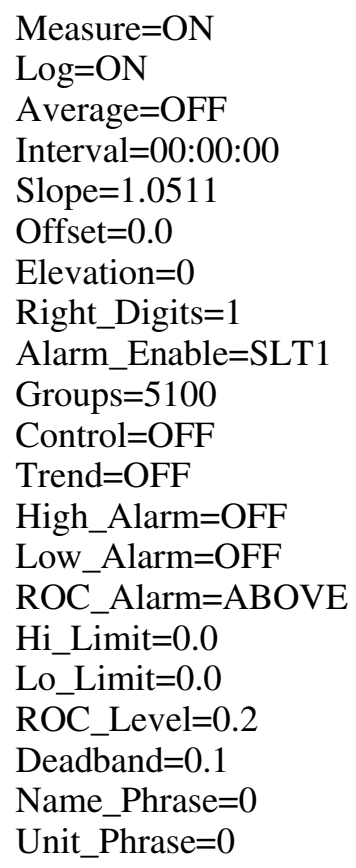

Wright Patman Lake Sutron 8200A Basic Program (TXKT2.BAS)

$10 \mathrm{~A}=$ Measure(SG1)

$20 \mathrm{~B}=$ Measure $(\mathrm{SG} 2)$

$30 \mathrm{C}=$ Measure $(\mathrm{SG} 3)$

$40 \mathrm{D}=$ Measure(SG4)

50 Open "TERM:" nowait

60 Control 1,2

70 Control 11,9600

80 PRINT 27\$;48;49\$;

90 PRINT "SG1 ";:PRINT A!3!1

100 PRINT 27\$;48\$50\$;

110 PRINT "SG2 ";:PRINT B!2!1

120 PRINT $27 \$ ; 48$;51\$;

130 PRINT "SG3 ";:PRINT C!2!1

140 PRINT $27 \$ ; 48$;52\$;

150 PRINT "SG4 ";:PRINT D!2!1

160 control 2 : close

170 stop

180 end 